GENIVALDO RODRIGUES SOBRINHO

\title{
EUGÉNIO TAVARES:
}

RETRATOS DE CABO VERDE EM PROSA E POESIA 
GENIVALDO RODRIGUES SOBRINHO

\section{EUGÉNIO TAVARES:}

\section{RETRATOS DE CABO VERDE EM PROSA E POESIA}

Tese de Doutorado apresentada ao Departamento de Letras Clássicas e Vernáculas da Faculdade de Filosofia, Letras e Ciências Humanas da Universidade de São Paulo (Área de Estudos comparados de Literaturas de Língua Portuguesa) como requisito parcial à obtenção do Grau de Doutor em Letras.

Orientadora: Professora Doutora Simone Caputo Gomes 


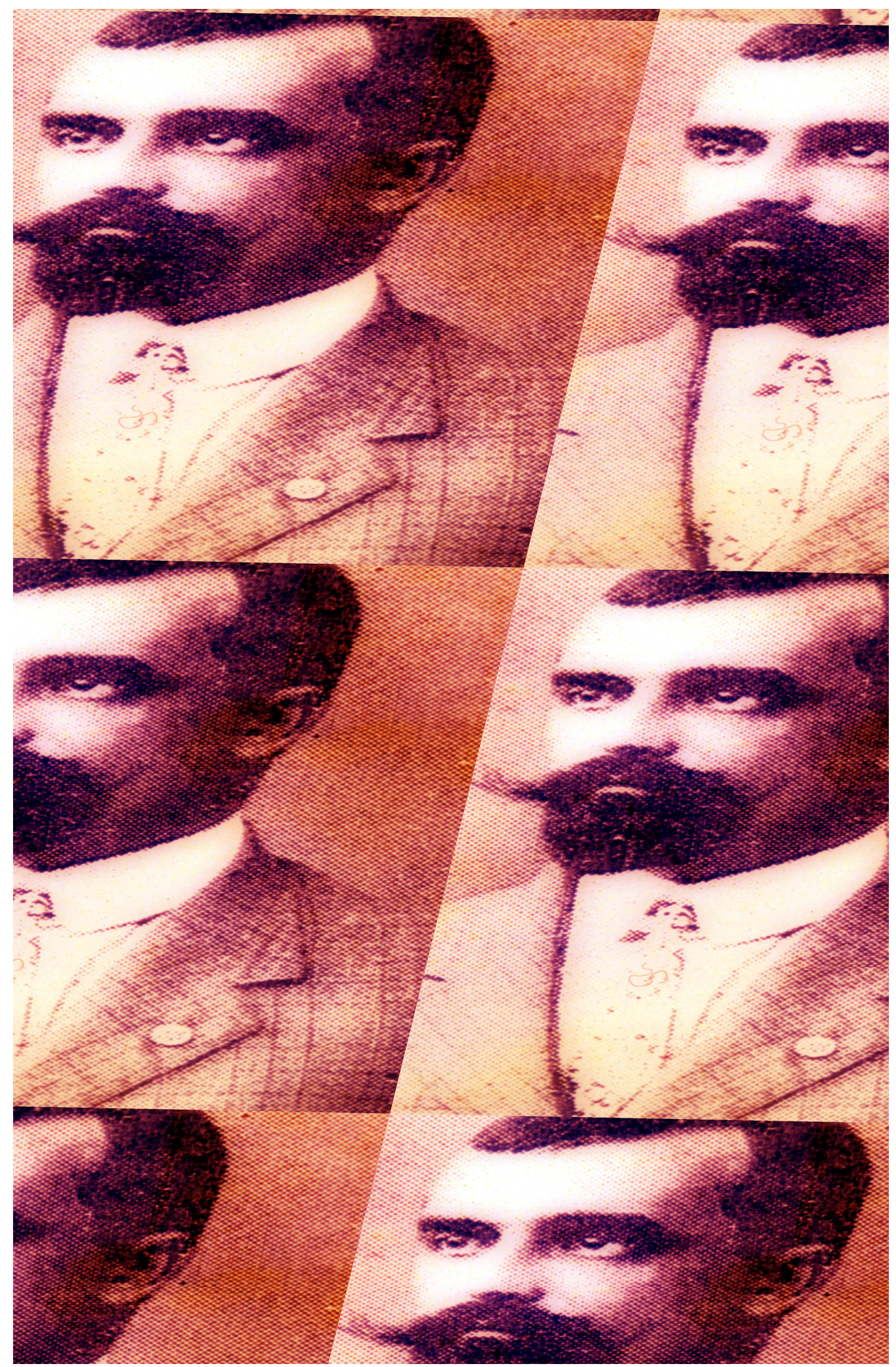

Imagem de Mito Elias - OTIMarte 


\section{DEDICATÓRIA}

Às minhas princesas, Neuza \& Maria Eduarda, merecedoras de todo o meu amor, dedicação e esforço e que me concederam muito do seu precioso tempo de convivência em troca da elaboração desta pesquisa.

Aos meus pais Francisco e Maria, meus mestres semeadores de todos os momentos, sem os quais a este patamar não chegaria.

Aos meus queridos irmãos Dora, Selma e Genilcio, uma força que me impulsiona sempre a buscar mais e mais. 


\section{AGRADECIMENTOS}

À professora Tania Macêdo pela amizade, pelas importantes sugestões durante a banca de qualificação, pelas relevantes contribuições desde o Mestrado e pela presença em momentos significativos de minha vida acadêmica.

À professora Simone Caputo Gomes, na qualidade de amiga e orientadora, pelos muitos e inesquecíveis diálogos, pela orientação, pela confiança depositada em nosso trabalho, pela seriedade e competência, pela presença decisiva durante nosso percurso intelectual e pelo encontro fraterno nestes três anos de convívio. Agradeço, sobretudo, o privilégio de ter trabalhado com alguém que realmente ama Cabo Verde, sua cultura e seu povo.

Ao professor Mário César Lugarinho, pela leitura atenta de meu relatório de qualificação, pelas observações pontuais e pelas sugestões visando a melhora de minha pesquisa.

À professora Walnice Matos Vilalva, pelo companheirismo, amizade e pelo apoio manifestado ainda na redação do pré-projeto de Mestrado.

À professora Vera Lúcia da Rocha Maquêa, que pela mão me fez adentrar o mundo USP, pela amizade que só se fortalece e por todo o incentivo inestimável.

À Verónica Oliveira, que gentilmente, com muita competência, fez o trabalho de tradução das mornas de Eugénio.

Ao artista plástico Mito Elias, pela cessão do seu trabalho plástico com a imagem de Eugénio Tavares, que ilustra esta tese.

Aos professores Benjamin Abdala Júnior, Maria Aparecida Santilli, Benilde Maria Justo Caniato (in memoriam), Rita Chaves, Vima Lia Rossi Martin, Elza Miné, Emerson Inácio e aos demais professores do Programa de Estudos Comparados de Literaturas de Língua Portuguesa que, direta ou indiretamente, contribuíram para a realização desta pesquisa.

Aos colegas de Mestrado e Doutorado: Ana Rabecchi, Agnaldo Silva, Antonio Mantovani, Elizabete Batista, Elizete Hunhoff, Irene Resende, Isaac Alemeida, Liliane Barros, Marinei Almeida, Nancy Young, Leonice Pereira Suzane Castrillon e Vera Maquêa, pela convivência ao longo desse período de qualificação. Em especial à Vera Maquêa, à Marinei Almeida, pelos diálogos construtivos desde o início da pesquisa e, sobretudo, ao Mantovani, pelo companheirismo, pela amizade e pela ajuda nos 
momentos de incertezas, e pela sempre presente colaboração em todas as horas.

Aos meus familiares paulistanos Mantovani, Simone, Vera, Lígia, Morgana, Érica Antunes, Flavinha Bandeca, Belelei, Carla Nardi, Dorothy Gomes, Avani, e Giselle Ribeiro por todas as nossas aventuras, alegrias e momentos de descontração na terra da garoa, bem como aos campineiros: seu Antonio, dona Elvira, Márcia, Gustavo, Adriana, Marcelo e Alessandra.

Aos amigos Renato e Elisângela, Rafael e Flavinha, Luiz e Juliana, Cida Bosco, Letícia, Avani e Humberto, Marana, Eduardo e Mara, Ricardo e Daiane, Júlio e Gil, Edi e César, pelos momentos de alegria e descontração tanto na capital quanto no interior de São Paulo.

Aos amigos da "República de Mato Grosso" Malheiros, Francis, Luzia Oliva, Yasmin Nadaf, Adriana Venturoso e Aldina Cássia, pelo calor humano e pelas energias positivas.

Aos inúmeros amigos cabo-verdianos que muito contribuíram para que este trabalho alcançasse o sucesso almejado. Em especial ao escritor Artur Vieira, ao Daniel Miranda e ao Joaquim Tavares, bravenses que não mediram esforços para arrumar os textos que servem como corpus da pesquisa.

Ao Cônsul Geral de Cabo Verde, presença amiga e fundamental para o conhecimento da morabeza crioula.

Ao José Augusto do Rosário e todo o seu pessoal da Associação Caboverdeana do Brasil, que sempre me prestigiaram nas promoções de eventos acerca da cultura cabo-verdiana em Santo André.

Ao Déni Mendes e a todos os integrantes da União dos Estudantes Caboverdianos do Estado de São Paulo - UECESP, pela morabeza do encontro.

À UNEMAT - Universidade do Estado de Mato Grosso, pela concessão da licença integral para a minha qualificação.

À Coordenação de Apoio à Pesquisa do Ensino Superior - CAPES, pelo pagamento de 24 meses de bolsa.

A todos os meus colegas do Departamento de Letras do Campus Universitário de Sinop - MT, pelo apoio e torcida.

Aos funcionários da USP e da UNEMAT, pela presteza em todos os momentos. Às secretárias do CELP, Creusa e Mari, e aos secretários da Pós-Graduação Lina, Dayane e Elias, pela atenção e bom atendimento ao longo desta caminhada. 


\section{A Morna}

Canto que evoca

a Maria Teresa Barbosa coisas distantes

que só existem

além

do pensamento,

e deixam vagos instantes

de nostalgia,

num impreciso tormento

dentro

das nossas almas...

Morna

desassossego,

voz

da nossa gente,

reflexo subconsciente

em nós

das vagas ao longo das praias;

das aragens

que trazem um sorriso bom

às equipagens

dos barquinhos à vela

e flexibilidades graciosas

às folhagens

do milharal,

musicando rapsódias em surdina

nos tectos das casas pobres...

Jorge Barbosa 
RODRIGUES-SOBRINHO, G. Eugénio Tavares: retratos de Cabo Verde em prosa e poesia. 2010. 200 f. Tese (Doutorado) FFLCH - Faculdade de Filosofia, Letras e Ciências Humanas, Universidade de São Paulo, São Paulo, 2010.

RESUMO: A leitura comparativa das produções em prosa e poesia que compõem a obra literária de Eugénio Tavares possibilita a compreensão da importância da participação dos escritores nativistas para a construção da nação Cabo Verde, da sua cultura e para a formação de sua série literária. Buscaremos nas produções jornalística e epistolar eugenianas traçar um panorama do contexto cabo-verdiano da virada do século dezenove para o vinte, destacando-lhes o propósito de denúncia das principais questões sociais, econômicas e políticas, assim como as aspirações libertárias que preocupavam os intelectuais cabo-verdianos da época. Na poesia, que ora se expressa em língua portuguesa, ora nas mornas em língua cabo-verdiana (crioulo), daremos ênfase a aspectos que fazem confluir a arte eugeniana para um ultrarromantismo tardio, de raiz lusa e, ao mesmo tempo, a estratégias que rasuram este estilo a partir de dentro, por meio de artifícios como a crítica e o humor carnavalizador. Quanto à morna, documento de registro da consciência coletiva, recorte de um patrimônio histórico, cultural e humanístico, submetida à mestria da pena de Eugénio Tavares, constituirá, além de uma marca identitária crioula, um dos marcos do lirismo literário cabo-verdiano. A opção de trabalhar com o cotejo de textos de diferentes gêneros manifesta a nossa tentativa de captar a riqueza com que Eugénio Tavares se apresenta e representa Cabo Verde em sua obra.

Palavras-Chave: Literatura cabo-verdiana, Eugénio Tavares, cultura crioula, morna, prosa, poesia. 
RODRIGUES-SOBRINHO, G. Eugénio Tavares: portraits of Cape Verde in prose and poetry. 200 f. Tese (Doutorado) - Faculdade de Filosofia, Letras e Ciências Humanas, Universidade de São Paulo, São Paulo, 2010.

\begin{abstract}
The comparative reading of the productions in prose and poetry that make up Eugénio Tavares's literary work enables the understanding of the importance nativist writers' participation for the building of Cape Verde nation, its culture and the formation of its literary series. We will try to establish an outline of the Cape Verdean context from the turn of the nineteenth century to the twentieth one by analysing Eugénio Tavares's journalistic and epistolary productions and emphasing the purpose of complaint of the main social, economical and political quests as well as libertarian aspirations which worried Cape Verdean intellectuals of that time. In poetry, which sometimes expresses itself in Portuguese language, sometimes in the morna in Cape Verdean language (Creole), we will hilight the aspects that make eugeniana art converge to a late ultrarromanticism of Lusitanian root and at the same time, the strategies that erasure this style from within, through devices such as criticism and carnavalizador humor. Concerning the morna, the registration document of the collective consciousness, a piece of a historical, cultural and humanistic heritage, submitted to Eugénio Tavares's mastery of writing, will constitute, besides being an identitary Creole trait, one of the landmarks of Cape Verdean literary lyricism. The option of working with the collation of texts from different genres expresses our attempt to capture the richness with which Eugénio Tavares presents himself and represents Cape Verde in his work.
\end{abstract}

Key-words: Cape Verdean literature, Eugénio Tavares, Creole culture, morna, prose, poetry. 


\section{ABREVIATURAS}

TPJ - Tavares - pelos jornais

TVTCP - Tavares - Viagens, tormentas, cartas e postais

TPOLP - Tavares - Poesia em língua portuguesa

TMCC - Tavares - Mornas - cantigas crioulas 


\section{SUMÁRIO}

REFLEXÕES INTRODUTÓRIAS - Eugénio Tavares: um precursor da cabo-verdianidade

Capítulo I - Eugénio Tavares: o amor a Cabo Verde na prosa de intervenção social

Capítulo II - A poética de Eugénio Tavares em língua portuguesa .

2.1 - O núcleo ultrarromântico: amor idealista e mal-do-século 70

2.2 - O núcleo do "terra-longismo"

2.3 - O núcleo da problemática social cabo-verdiana e as estratégias de abordagem

2.4 - Núcleo da reflexão filosófica e religiosa

Capítulo III - Mornas - cantigas crioulas: poesia em língua "sabe"

3.1 - Morna, modalidade musical identitária cabo-verdiana: origens e polêmicas críticas

3.2 - Diferenças entre a morna da Boavista e a da Brava: a contribuição de Eugénio Tavares

3.3 - A obra mornística de Eugénio Tavares

3.4 - A morna amorosa de Eugénio Tavares

3.5 - Morna(s) da partida 


\section{REFLEXÕES INTRODUTÓRIAS: EUGÉNIO TAVARES， UM PRECURSOR DA CABOVERDIANIDADE}

Português de lei! Cabo-verdiano de alma! Eugénio Tavares

O trabalho que ora nos propomos a realizar tem por objetivo fulcral empreender uma leitura da obra de Eugénio Tavares norteada pelo levantamento de como interagem as múltiplas faces de seu discurso em prosa - jornalística e epistolar - e poesia, em língua portuguesa e cabo-verdiana, fornecendo ao leitor uma visão de Cabo Verde e sua cultura, na época em que se inscrevem as suas intervenções. E também, para além, como a figura do intelectual e a força de sua produção literária e de sua atuação na imprensa se transformam em símbolos de cabo-verdianidade gravados para sempre na memória coletiva, que reverberam até nossos dias.

Para tanto, nossa proposta será recolher e examinar os grandes temas que enlaçam a produção literária eugeniana ${ }^{1}$, observar como se entrelaçam com um retrato de Cabo Verde por meio da literatura e da produção intelectual, jornalística e epistolar de Eugénio num momento crucial da formação dos sentimentos de pertença e da série literária crioulos.

Investigar a atuação de Eugénio Tavares no seu tempo e sua importância para a formação de um sentimento de cabo-verdianidade acrescenta-se aos escopos acima referidos e a análise de sua epistolografia, em confronto com as posturas emitidas nos textos veiculados pela imprensa e por meio da poesia constitui uma etapa determinante para traçar um perfil do homem Eugénio Tavares e do que ele significa para a discussão de questões relativas à identidade cultural cabo-verdiana.

Parece-nos pertinente a assertiva de Manuela Ernestina Monteiro sobre a repercussão da práxis eugeniana na então colônia portuguesa: "De entre aqueles que se destacam como cultores distintos das letras cabo-verdianas no período que se convencionou designar por Pré-Claridade, Eugénio Tavares projecta-se para a posteridade, de forma indiscutível, através da obra que nos legou” (1999, p. 5).

\footnotetext{
${ }^{1}$ Com exceção do teatro dos contos, que julgamos merecer pesquisa à parte, em etapa futura de nossa pesquisa.
} 
E a sua formação autodidata nos leva a valorizar ainda mais o seu trabalho literário: mesmo não tendo freqüentado o Liceu de São Nicolau, nem tido a oportunidade de estudar em qualquer outro estabelecimento de ensino fora de seu país, Eugénio Tavares era possuidor de uma apurada bagagem cultural que viria a se refletir em sua produção escrita. Como jornalista e prosador, Eugênio Tavares dominou o cenário cabo-verdiano nas primeiras décadas do século XX. A este respeito, pronunciam-se Carlota e Viriato de Barros em texto de uma conferência proferida na cidade Lisboa, em 2005:

\begin{abstract}
A formação de Eugénio Tavares fez-se no excelente ambiente em que cresceu, entre gente de cultura e conhecimento, a cujas bibliotecas tinha acesso constante e que constituíam para ele autênticos santuários pessoais de estudo. [...] foi sobretudo aluno do seu povo, da sua terra, da sua ilha, da cultura do seu povo que amou sem condições, sofrendo as suas dores, lutando as suas lutas, sentindo como próprias as suas revoltas, porque doutra forma não podia ser, mas vivendo também os seus amores e as dores de quem ama com essa intensidade que se sente nos seus poemas ${ }^{2}$.
\end{abstract}

Sabe-se, portanto, que Eugénio Tavares - apesar de todas as limitações e dificuldades - superou os obstáculos em busca de seu desenvolvimento intelectual. Destacou-se, ademais, na devoção à justiça social face ao descaso do Governo central, bem como na militância pela causa republicana. No jornalismo, com seu talento e mestria na linguagem, Eugénio denunciava com veemência os graves problemas político-sociais vividos por sua gente.

A revelação do talento precoce de Eugénio Tavares foi fundamental para que o seu caráter combativo, questionador, voltado para sua nação e sua gente se moldasse e se fortalecesse para o prosseguimento de seus embates em favor de conquistas políticas e sociais imprescindíveis, sem o apelo fácil ao meramente panfletário.

Isabel Lobo, na introdução ao volume Eugénio Tavares: poesia, contos, teatro (1996), recolha organizada por Félix Monteiro, afirma que:

Eugénio Tavares é nome de referência na literatura cabo-verdiana. Os seus textos, ao percorrerem um leque vasto de géneros, uma linguagem muito característica da época, donde se não excluem influências várias como o romantismo e o classicismo renascentista, permitem hoje a compreensão mais consentânea de certos fenómenos sociais, cívicos e literários próprios dos finais do século XIX e início do XX cabo-verdiano (1996, p. 5, grifos nossos).

\footnotetext{
${ }^{2}$ Disponível em: www.eugeniotavares.org. Acesso em maio de 2010.
} 
Assim, nossa pesquisa se pauta por um viés comparativo que se afasta de uma linha transnacional ou de literatura comparada em senso estrito, para inserir-se mais numa perspectiva dos estudos culturais, confrontando gêneros diferentes de produção e apoiando-se na intertextualidade e na interdisciplinaridade para dar conta do objeto de comparação. Buscaremos fugir das relações binárias entre literatura nacional e literatura estrangeira, ou texto de um autor e texto de outro, para emergir numa leitura intraautoral, na pluralidade de gêneros experimentados, e pluridisciplinar, estabelecendo interlocução com outros ramos das ciências humanas.

A propósito, Helena Buescu declara que a Literatura Comparada pode ser entendida como "domínio cognitivo de cruzamento interdiscursivo, interdisciplinar e intersemiótico" (2001, p. 93). Nesse espaço intermediário, como declara Tania Carvalhal, "nos limites dos gêneros, nas margens dos textos, no espaço intervalar onde se concretiza o imaginário das zonas de contato, que facilitam o processo permanente de interação de elementos vários" (2003, p. 159), procuraremos operar.

Trabalharemos na linha do "desvio do olhar" que Eduardo Coutinho detecta nos estudos contemporâneos de Teoria, Historiografia e Crítica Literárias, que passam, a partir da década de setenta, a encarar o texto não exclusivamente "como objeto fechado na sua imanência estética, mas como artefato cultural” (1998, p. 57), que se configura de modo híbrido (como quer Canclini), incorporando elementos da "alta cultura" e da “cultura popular", em estrutura dialógica. O texto literário será examinado, então, como produto que se relaciona com outras áreas do conhecimento e ainda com textos de outros estratos culturais.

Acrescenta Isabel Lobo, corroborando a nossa metodologia de trabalho:

Se a obra de Eugénio Tavares tão diversa temática e formalmente, num percurso que hoje se refaz por este conjunto alargado de textos [a recolha de Félix Monteiro], proporciona uma visão "outra" do século passado cabo-verdiano deve-se também a uma escrita "paralela" - seja através de textos do próprio Eugénio Tavares (sob pseudônimo de Tambor-mor - "Um casamento nos Órgãos" e "O Tango e a Morna") ou de estudos da Morna ("A Morna" de Baltasar Lopes e "Breves Comentários às Mornas publicadas nesta colectânea", de Baltasar Lopes e José Alves dos Reis), nos quais os textos de Eugénio (as mornas) são referência obrigatória num contexto cultural tão rico como o cabo-verdiano, perfazendo-lhe o sentido num percurso de construção de significações. Esta escrita "paralela", porque complementar (muito se tem questionado sobre a importância de certos textos novecentistas da cultura cabo-verdiana, o que será aferido também pelo olhar dos seus contemporâneos ou concidadãos - 
questões de recepção do texto), assim sendo, projecta uma visão novecentista da sociedade cabo-verdiana culturalmente dinâmica e polifacetada $(1999$, p. 7$)$.

De forma alguma, Machado e Pageaux (1988) elegem o estudo do tema como o objeto de trabalho do comparativista. Os teóricos acreditam que o investigador de obras ou produções em comparação faces indissociáveis da investigação literária: o estudo do funcionamento interno dum texto (dum tema num texto, a leitura para pôr em evidência, para reconstruir um conjunto de funções) e o estudo da função social e cultural desse mesmo texto (pp. 120-121), é obrigado a fazer duas leituras simultâneas: a primeira, no plano da representação literária como universo próprio e coerentemente estruturado; segunda, para fazer conexões entre os elementos estruturais e os culturais em que se insere o texto, passando, assim, de uma análise formalista a uma análise extratextual, sem que uma exclua a outra. Para Machado e Pageaux,

o texto literário é o lugar dialético onde se articulam estruturas textuais e extra-textuais, participando o tema, justamente, das duas séries. $\mathrm{O}$ estudo temático revela, afinal, claramente, as duas

Com esse espírito, procuramos abordar a obra de Eugénio Tavares, no sentido de dar visibilidade às causas de sua singularidade e proeminência no panorama literário e cívico cabo-verdiano.

O século XIX, como todo o período anterior da literatura de Cabo Verde, era impactado, enquanto produção estética e literária, pelos modelos europeus. As bases em que se estruturará uma nova etapa da produção literária em Cabo Verde, anunciada na revista Claridade, já eram discutidas e debatidas anteriormente por Eugénio Tavares. Sua produção, questionadora dos rumos não só da literatura, como também de Cabo Verde como nação, deu-se no período denominado por alguns críticos e estudiosos de "pré-claridoso", a que outros denominam de nativista.

Em sua poética, Eugénio busca da tradição crioula a morna, representante máxima da alma cabo-verdiana, aproximando o discurso literário da canção e da fala do povo. Nos textos em prosa e nas crônicas veiculadas no jornalismo, o autor enfoca questões de natureza política e social (o texto engajado já abre um debate sobre a necessidade da independência política, social e cultural de Cabo Verde). Sua produção, inovadora para a época, opera a confluência entre a arte culta e a arte popular. Nesse 
encontro, o autor resgata as formas tradicionais e preserva o patrimônio imaterial crioulo, que dialoga com os modelos consagrados na literatura lusa.

A ilha Brava é o cenário perfeito para retratar as vivências crioulas, mesmo com todas as suas dificuldades e carências; é sempre com muito carinho e amor que Eugénio se refere à sua terra de origem. Percebe-se, nesse movimento de descrição do seu torrão natal, uma vontade de que o locus privilegiado na obra não seja apenas a Brava, mas o Arquipélago como um todo. Para Manuela Ernestina Monteiro:

Eugénio recriou a sua ilha tanto nos versos como na prosa: o relevo, a beleza da natureza, na qual as flores e os aromas ocupam lugar de destaque, actos da vida quotidiana bravense, sem esquecer alguns hábitos e costumes, numa palavra, a atmosfera típica da ilha Brava $(1999$, p. 8).

$\mathrm{Na}$ sua concepção, a ilha Brava representa a pátria/mátria ${ }^{3,}$ na senda da discussão empreendida por Manuel Ferreira (1987, p. 83).

João Nobre de Oliveira, sobre a importância da ilha Brava na época em que viveu Eugénio Tavares, esclarece:

Com um clima mais suave, que lembrava o da metrópole [...], a Ilha Brava tinha tudo para atrair os governadores que chegavam a residir nela meio ano, apesar da capital ser na ilha de Santiago. Foi, também, a este hábito que a Brava deve o facto do governo ter instalado ali, em 1847, a primeira Escola Principal de Instrução Primária de Cabo Verde em vez de instalá-la na capital da província. E não era só o governo que tinha os olhos postos na ilha. Já em 1845, o bispo D. João Henriques Moniz apresenta um relatório ao governo em que propunha a criação de um seminário-liceu em Cabo Verde, que deveria ser instalado na ilha Brava. [...] Era natural que a ilha Brava registasse um intenso progresso a partir de então, pois, para que o governo pudesse funcionar eficazmente, havia que criar um mínimo de condições, e muitos serviços foram então aí instalados, ou tiveram o seu começo [...] o que, naturalmente, favoreceu os bravenses. Só assim se pode compreender como uma ilha tão pequena e com uma população tão diminuta, tenha desempenhado um papel de relevo nas letras e na política de Cabo Verde, na segunda metade do século passado. A Brava forneceu funcionários públicos, oficiais do exército, médicos, magistrados, professores, padres, que brilharam no governo da província e em outras terras do Império Português (1998, p. 47).

\footnotetext{
${ }^{3}$ Manuel Brito Semedo nos informa que "O conceito de Mátria foi primeiramente utilizado pelo Padre António Vieira, em 1639, no "Sermão de Nossa Senhora da Conceição", pregado na igreja de Nossa Senhora do Desterro, na Baía, no contexto de a Terra ser desterro e o Céu a verdadeira e bem-aventurada pátria (2006, p. 266).
} 
A pequena ilha concentrou um grande número de pessoas com nível intelectual elevado e em cargos importantes nas hierarquias de Cabo Verde e da Guiné, o que refletiu positivamente na sua vida cultural e política. A certa altura, pela quantidade e qualidade de eventos literários, a Brava tornou-se uma ilha de poetas, dos quais podemos destacar Guilherme Dantas, Luís Medina, Maria Luisa de Sena Barcelos, José Bernardo Alfama, ente outros.

Ao final do século XIX, em consequência, a Brava tornou-se uma ilha republicana e antimonárquica (OLIVEIRA, 1998, p. 48), o que justifica no seu cenário o surgimento de um intelectual do porte de Eugénio Tavares.

A respeito da imagem que os bravenses faziam de Eugénio Tavares, lembramos as palavras do escritor Luís Romano, quando de sua ida à Brava, por volta de 1980, em busca de "relíquias" sobre Eugénio:

As estórias se embrulham e fica somente a evocação de um Ente Querido, quase mitológico, que foi e é adorado pela gente amorável da sua ilha Brava, a quem serviu de defensor e quase sempre mentor ou até juiz. [...] Há sempre alguém que se lembre de um improviso, de uma graça, de uns versos, de uma partida ou de uma sentença de Nho Eugénio (1986, p. 3).

Destarte a admiração que, a exemplo dos bravenses e dos compatriotas caboverdianos das outras ilhas, nutrimos por Mestre Eugénio, ancoraremos nosso trabalho de pesquisa numa base teórico-metodológica que privilegiará a interlocução entre os textos eugenianos de variados gêneros e nas línguas cabo-verdiana e portuguesa apoiada numa visão dos estudos culturais calcada na interdisciplinaridade com a História, a Sociologia, a Antropologia, a Etno-Musicologia e os Estudos Literários.

Buscaremos, para isso, estabelecer, sempre que possível, a par do diálogo entre as obras literárias (intertextual), um diálogo das produções com o contexto em que se insere a obra de Eugénio Tavares, ou seja, o final do século XIX na transição para o século XX, em que Cabo Verde ainda se encontrava sob o domínio do Império Colonial Português. Nesse sentido, faz-se necessária a recorrência a apoios teórico-críticos, para o estudo das questões sociais e identitárias, como os de António Carreira (Cabo Verde, aspectos sociais, secas e fomes do século XX), Manuel Ferreira (A aventura crioula), Gabriel Mariano (Cultura caboverdeana: ensaios), Luís Peixeira (Da mestiçagem à caboverdianidade: registos de uma sociocultura), Leila Leite Hernandez (Os filhos da terra do sol:a formação do estado-nação em Cabo Verde), bem como suportes para a 
avaliação do papel da imprensa na formação da cabo-verdianidade nascente (paralelamente à dominação portuguesa), como os propostos por João Nobre de Oliveira (A imprensa cabo-verdiana 1820-1975) e Manuel Brito-Semedo (A construção da identidade nacional - análise da imprensa entre 1877 e 1975).

Os conceitos de identidade cultural e de memória coletiva, imbricados na discussão das questões sociais e identitárias referidas no parágrafo anterior, serão retomados de Stuart Hall (A identidade cultural na pós-modernidade) e Maurice Halbwachs (A memória coletiva). Neste caso, assim como no que toca a outros apoios teórico-críticos que embasam nosso estudo, optaremos por diluir as categorias e conceitos no corpo da tese, à medida que vão sendo necessários, ao invés de construir um capítulo teórico em separado.

No caso específico do estudo da morna, a base teórico-crítica fundamental para nossa investigação prende-se, sobretudo, às reflexões da área de etno-musicologia do maestro Vasco Martins (A música tradicional cabo-verdiana I: a morna; e "Ventos alíseos"), de Moacyr Rodrigues e Isabel Lobo (A morna na literatura tradicional: fonte para estudo histórico-literário e a sua repercussão na sociedade), de António Germano Lima (A morna: sintese da espiritualidade do povo cabo-verdiano), José Alves dos Reis (“Subsídios para o estudo da morna”), Gláucia Nogueira (No tempo de B. Léza: documentos e memórias), Carlos Filipe Gonçalves (Kab Verd Band).

No que diz respeito ao recurso da literatura cabo-verdiana à tradição cultural de cunho oral, especialmente a relação poesia culta-morna, buscaremos auxílio a linhas mais recentes de pesquisa como a desenvolvida por Simone Caputo Gomes, que elegerá a morna como matriz de várias gerações de textos literários.

O maestro e poeta Vasco Martins, em sua obra A música tradicional caboverdiana - I (A morna), considera que:

A Morna, forma de música cabo-verdiana, é essencialmente uma temática sensitiva e elegante, dramatização das aspirações e do conceito do imaginário do povo cabo-verdiano, uma temática popular e tradicional muito própria e de grande valor universal (1988, p. 9).

Eugénio Tavares, como pretendemos demonstrar, elevou a morna a um estatuto literário, legando-lhe uma importância tal que lhe permitiu alçar-se como símbolo de Cabo Verde ou como "bilhete de identidade" que une os cabo-verdianos em qualquer parte do mundo. 
$\mathrm{Na}$ relação da morna e de outros textos eugenianos (em língua portuguesa) com a emigração ou o tema que denominaremos de "terra-longismo", apoiar-nos-emos em proposições de Manuel Ferreira (“O círculo do mar e o ‘terra-longismo’ em ‘Chiquinho’ de Baltasar Lopes”), Luís Silva (“Os exílios na literatura caboverdiana”), Gabriel Mariano ("Amor e partida na poesia crioula de Eugénio Tavares ou inquietação amorosa"), João Lopes Filho (Imigrantes em terra de emigrantes), Juliana Braz Dias ("Images of emigration in Cape Verdean music"), Luís Batalha \& Jorgen Carling (orgs. Transnational archipelago: perspectives on Cape Verdean migration and diaspora).

Para a leitura da poética de língua portuguesa, os traços relativos ao mal-doséculo e à linguagem ultrarromânticos necessitarão de enfoque mais detalhado e, para realizá-lo, recorreremos à história da literatura portuguesa e aos textos de Vítor Manuel Aguiar e Silva (Teoria da literatura), António José Saraiva \& Óscar Lopes (História da literatura portuguesa), Teófilo Braga (Introdução e teoria da história da literatura portuguesa e História da literatura portuguesa VI: o ultra-romantismo), Jacinto do Prado Coelho (Dicionário de literatura), Alberto Ferreira (Perspectiva do romantismo português: 1833-1865), José-Augusto França (O Romantismo em Portugal), Helder Garmes (A convenção formadora: uma contribuição para o periodismo literário nas colônias portuguesas) e Antônio Carlos Oliveira Santos (Eugénio Tavares: poesia e convenção romântica), que abordam a especificidade do estilo.

$\mathrm{Na}$ sua apresentação, nosso trabalho segmenta-se na forma que a seguir enunciaremos.

O primeiro capítulo, de título Eugénio Tavares: o amor a Cabo Verde na prosa de intervenção social, enfocará as produções jornalística e epistolográfica eugeniana, com o intuito de acompanhar os passos que o intelectual dá rumo à construção de um Cabo Verde digno, mais cidadão e pautado pela justiça. A análise das crônicas tavarianas publicadas nos jornais e das correspondências com seus familiares, amigos e outros intelectuais do arquipélago e do exterior, buscará mostrar em que medida se manifestam suas preocupações e intervenções sociais. Para que o estudo alcance o resultado que desejamos, será preciso fazer um recorte em que procuraremos elencar os textos mais significativos, nos quais o autor procurou representar Cabo Verde. Corsino Fortes sustenta que, em suas cartas, e acrescentamos, em seus textos 
publicados em jornais, Eugénio Tavares "estabelece o retrato moral, social e político da história da época" ${ }^{4}$.

No segundo capítulo, intitulado A poética de Eugénio Tavares em língua portuguesa, procedermos a uma seleção dos principais poemas em língua lusa, nos quais possamos verificar imagens trabalhadas pelo autor em que Cabo Verde, seu imaginário, sua "epopéia sentimental" se façam representar. Esta produção começou a vir à tona na adolescência de Eugénio, com a publicação de um texto no Almanaque de Lembranças Luso-Brasileiro, e se mostrou bastante profícua ao longo de sua vida.

O método a ser utilizado na análise dos poemas se constituirá da observação de sua estrutura - formas fixas, rimas, ritmos, tempos e modos verbais, pontuação -, de sua composição temática e da verificação de supostos entrelaçamentos sociais e/ou históricos. A ressonância de um ultrarromantismo tardio em Cabo Verde na produção poética em língua portuguesa de Eugénio Tavares merecerá uma focalização mais atenta de nossa parte, que possa posteriormente dialogar com o lirismo amoroso dominante nos poemas em línga cabo-verdiana.

No capítulo terceiro, Mornas - cantigas crioulas: poesia em língua "sabe", buscaremos adentrar o mundo cultural crioulo, expresso na sua representante identitária, a morna, da qual Eugénio Tavares foi o mais consagrado cultor. Para investigar esta produção eugeniana em língua cabo-verdiana, inicialmente, contaremos com o auxílio de uma tradutora cabo-verdiana que verterá os textos para a língua portuguesa (de modo a auxiliar o nosso eventual leitor, que provavelmente não domina o crioulo caboverdiano da Brava) e, posteriormente, iremos ao encontro de estudos históricos, críticos e etno-musicais que iluminem a singularidade da contribuição de Eugénio Tavares (Nhô Tatai) para a evolução da modalidade no arquipélago desde sua origem até a sua transformação na modalidade musical identitária cabo-verdiana.

Os temas fundamentais das mornas serão expostos, de modo a podermos cotejar as produções poéticas eugenianas em língua crioula e em língua portuguesa, inferindo até que ponto se tocam ou se afastam.

Embora Stuart Hall afirme que o conceito de identidade "é demasiadamente complexo, muito pouco desenvolvido e muito pouco compreendido na ciência social contemporânea" (HALL, 1997, p. 8), encontraremos nele apoio para examinar como a

\footnotetext{
${ }^{4}$ Disponível em: http://www.eugeniotavares.org/docs/pt/obra/cartas.html
} 
obra de Eugénio Tavares, como um todo múltiplo (e, em especial, as suas mornas crioulas), atribui uma identidade cultural a Cabo Verde, em sua época e para além dela.

Para Stuart Hall, uma identidade cultural enfatiza aspectos relacionados à nossa pertença a culturas étnicas, raciais, linguísticas, religiosas, regionais e/ou nacionais. Ao analisar a questão, este autor focaliza particularmente as identidades culturais referenciadas às culturas nacionais, concebendo a nação como um sistema de representação cultural composto de símbolos que fundamentam a constituição de uma dada identidade coletiva. Segundo Hall, as identidades coletivas nacionais, regionais ou locais são formadas e transformadas no interior de uma larga rede de representações sociais (HALL, 1997, p. 53); as culturas nacionais produzem sentidos com os quais podemos nos identificar, contidos em estórias, memórias e imagens que servem de referências ou nexos para a constituição de uma identidade da nação.

Também os estudos empreendidos por Maurice Halbwachs (1990) contribuirão significativamente para a compreensão dos quadros sociais que compõem a memória. Para o sociólogo francês, "memória coletiva é o processo social de reconstrução do passado vivido e experimentado por um determinado grupo, comunidade ou sociedade 5 . Este conceito nos dará suporte para avaliar o estatuto simbólico tanto da personagem Eugénio Tavares quanto de sua obra literária para a formação de uma memória coletiva da nação cabo-verdiana e para a referenciação de uma identidade cultural (Hall).

Halbwachs postula que a memória individual interage com a sociedade, seus grupos e instituições. É no contexto destas relações ou "comunidade afetiva" que as lembranças individuais são construídas. Assim, à memória coletiva cabe a função de enraizar o sentimento de pertença a um grupo de passado comum, que compartilha memórias. Ela garante o sentimento de identidade do indivíduo, ancorado numa memória compartilhada, sobretudo no campo do simbólico.

Consequentemente, a memória coletiva tem seu lugar na tradição e, simultaneamente, a dinamiza. Conclui Halbwachs que a memória coletiva, desempenha um papel fundamental nos processos históricos, preservando o passado e vitalizando os objetos culturais. Franco Cardini, sobre o lugar dessa memória coletiva nos processos históricos, segundo a ótica de Halbwachs, elucida:

\footnotetext{
${ }^{5}$ La memoria colectiva es el proceso social de reconstrucción del pasado vivido y experimentado por um determinado grupo, comunidad o sociedad. HALBWACHS, 1991, p. 2.
} 
a grande protagonista da história é a memória coletiva, que tece e retece, continuamente, aquilo que o tempo cancela e que, com a sua incansável obra de mistificação, redefinição e reinvenção, refunda e requalifica continuamente um passado que, de outra forma, correria o risco de morrer definitivamente ou de permanecer irremediavelmente desconhecido (1988, p. xii).

Fundamentando-nos nesses constructos, analisaremos a obra literária de Eugénio Tavares, nas suas variadas modalidades, encarando-a como passado que, inscrito de forma indelével na memória coletiva, compartilhada, revitaliza-se num presente que a ela recorre para identificar-se em processos $^{6}$ reiterados de pertencimento a um Cabo Verde destemido, reivindicativo, justo e livre. Não por acaso as mornas de Eugénio Tavares têm sido referidas como expressões da "alma cabo-verdiana", pois que a "comunidade afetiva" as associa à manifestação singular dos sentimentos crioulos.

Afirma Manuel Brito-Semedo que

Eugénio Tavares até hoje seria o mais importante jornalista que surgiu até então, pelas posições assumidas quando entrou no projeto d'A Voz de Cabo Verde, como chefe de redação, num jornal, na altura, radical, de uma posição radical [...]. Tinha posições firmes e assumia isso. A vida dele era toda assim. Era um homem consequente, não separo a vida dele das posições políticas da escrita, ele tinha essas posições (2009).

Eugénio Tavares é reconhecido como uma das balizas da cultura cabo-verdiana de todos os tempos. Este reconhecimento se dá devido à produção literária, musical, jornalística e epistolar (além de contos e teatro), marcada principalmente pela originalidade de seus temas. Desta forma, justifica-se o desenvolvimento deste estudo, uma vez que Eugénio Tavares representa um dos grandes patrimônios culturais de seu país. Acreditamos, porém, que nosso empenho na pesquisa das grandes linhas desta produção contribuirá para que a imagem de ente mitológico se esbata um pouco para deixar reluzir as qualidades que consagram Eugénio Tavares como um marco definitivo no rol dos grandes nomes da literatura e da cultura cabo-verdianas.

\footnotetext{
${ }^{6}$ Conceito proposto por Boaventura de Sousa Santos: identidades como identificações em processo.
} 


\title{
CAPÍTULO I - EUGÉNIO TAVARES: O AMOR A CABO VERDE NA PROSA DE INTERVENÇÃO SOCIAL
}

\author{
Escolhei a vossa pena como os heróis escolhem as suas lanças; \\ há penas nobres como espadas, há penas reles como escovas de sapatos.
}

Eugénio Tavares

Eugénio Tavares, um dos intelectuais cabo-verdianos mais atuantes, legou às gerações posteriores não apenas a forma modelar da morna bravense, mas também importantes subsídios para a construção de uma nação mais digna e justa. Nesse sentido, a sua produção em prosa, espalhada nos mais diversos jornais que circularam em Cabo Verde e Portugal entre o final do século XIX e as primeiras três décadas do século XX, revela um Eugénio Tavares comprometido com a "verdade" e com a defesa dos interesses do povo cabo-verdiano.

João Nobre de Oliveira, ao discorrer sobre a sua atuação como jornalista, evidencia que

\footnotetext{
A sua pena tornou-se temida no meio político cabo-verdiano e colaborou nos órgãos republicanos Voz Pública, Batalha e Marselhesa; [...] em vida, Pedro Cardoso considerou-o o maior jornalista cabo-verdiano (OLIVEIRA, 1998, p. 201).
}

Suas crônicas e cartas, recolhidas por Félix Monteiro sob o título de Eugénio Tavares - viagens, tormentas, cartas e postais (1999), fornecem-nos um retrato da sua personalidade marcante e da vasta cultura que dominava.

A leitura mais minuciosa, nesta oportunidade, de textos tavarianos publicados em periódicos, especialmente a Revista de Cabo Verde e o jornal A Voz de Cabo Verde, assim como de peças selecionadas de sua produção cronística e epistolar, busca demonstrar como o autor desenvolveu suas reflexões contra as injustiças sociais, desmandos de autoridades, abandono do arquipélago por parte da metrópole num discurso de teor interventivo, que tinha por objetivo a construção de um Cabo Verde mais humano.

Antes, porém, julgamos necessário fazer um breve histórico da chegada da imprensa ao arquipélago de Cabo Verde, com o intuito de conhecer as circunstâncias 
que motivaram a criação da imprensa não-oficial naquela então colônia portuguesa da costa ocidental africana.

A instalação da primeira tipografia nas colônias portuguesas na África aconteceu em 1842, quase quatro séculos após a chegada dos portugueses às ilhas de Cabo Verde e 402 anos depois que Gutenberg inventou a imprensa. Sob a égide da Imprensa Nacional de Cabo Verde e Guiné, a 24 de Agosto de 1842, na vila de Sal-Rei, ilha da Boa Vista, dava-se à estampa o primeiro número do Boletim Oficial do Governo Geral de Cabo Verde. Com este feito, o arquipélago acabaria por se transformar em pioneiro da imprensa na África portuguesa.

Apesar do seu pequeno número de páginas, este boletim dividia-se em duas secções: a "Interior" e a "Exterior". A primeira secção subdividia-se, por sua vez, em duas partes: a "Parte Oficial", onde se publicavam textos do Governo, e a "Parte não Oficial", que se destinava à publicação de outros textos que pudessem ser úteis aos leitores do Boletim Oficial. Publicado até o número 32, antes de se fixar definitivamente na cidade da Praia, na Ilha de Santiago, em 1855, o Boletim também foi editado na Brava, por ocasião da transferência da Imprensa Nacional para a Ilha das Flores, em virtude da epidemia que então assolava a ilha da Boa Vista, obrigando o deslocamento dos funcionários mais influentes, assim como do próprio Governador.

Tornou-se o veículo de informação oficial de Cabo Verde e do Distrito da Guiné Portuguesa até o ano de 1879, quando houve o desmembramento desta província do governo cabo-verdiano. A partir de então, o Boletim permaneceu exclusivamente a serviço do arquipélago, como Boletim Oficial do Governo da Província de Cabo Verde.

Ainda no que diz respeito à instalação da imprensa em solo cabo-verdiano, João Nobre de Oliveira esclarece que:

apesar da sua primazia na instalação do prelo em terras de África, Cabo Verde foi das últimas colónias portuguesas a ter um jornal. Foi em Angola, na cidade de Luanda, em 1855, que nasceu o primeiro jornal da África portuguesa: o Aurora. Era uma revista literária mas a sua fundação representa de facto a aurora do jornalismo africano de língua portuguesa. A Angola, seguiram-se Moçambique com o Progresso, editado na cidade de Moçambique em 1868; S. Tomé e Príncipe, com o Equador em 1870; Cabo Verde com o Independente, na cidade da Praia, em 1877 e, por último, Guiné-Bissau com o Ecos da Guiné, saído em Bolama, em 1920. Quanto a essa última excolónia há a registar que em 1883 foi editada uma folha intitulada Fraternidade na cidade de Bolama, folha essa - número único - cuja 
venda se destinava a angariar fundos para apoiar Cabo Verde, então a braços com uma crise (OLIVEIRA, 1998, p. 18).

A história da edição de jornais com temáticas que procuravam dar ênfase aos problemas gerados nas colônias iniciou-se por volta do ano de 1836. Eram periódicos voltados para o ultramar e tinham a preferência dos habitantes das províncias para o caso de denunciar problemas que os afetavam, atacar governantes pouco interessados em dinamizar a administração e, consequentemente, melhorar a vida das províncias, discutir ideias políticas etc.

A vantagem da publicação de textos em jornais metropolitanos resumia-se ao fato de os produtores destes textos não arriscarem a perder a liberdade, uma vez que muitos deles estavam nas fileiras do emprego público. Nas colônias, a liberdade de imprensa não era um princípio observado e as autoridades costumavam proibir matérias que não considerassem convenientes. Todavia, essas mesmas autoridades não tinham o poder de proibir a publicação na metrópole, bem como de impedi-la de circular nas colônias, o que inviabilizava represálias contra seus autores.

Em Cabo Verde, tendo ficado sob sua a incumbência a manutenção da circulação de um único periódico, o governo deu-se por satisfeito com esse órgão solitário de imprensa durante praticamente todo o século XIX. Esta situação se alteraria somente no século $\mathrm{XX}$, quando, ainda por iniciativa do governo ou de outros organismos dele dependentes, novos títulos foram criados. Complementa ainda João Nobre de Oliveira:

A evolução da Imprensa em Cabo Verde, no entanto, pode ser vista de um outro ângulo. Assim, partindo em 1842 de uma publicação mantida pelo Estado, passa em 1877 para dois jornais independentes, que conseguem sobreviver algum tempo sem o apoio estatal. Segue-se um novo período em que só o Boletim Oficial consegue sair regularmente, mas marcado, aqui e além, pelo aparecimento de publicações de pouca duração (1998, p. 26).

Apesar de todas as dificuldades, os cabo-verdianos encontraram na publicação de opúsculos, cujo tamanho girava em torno de cinqüenta (50) páginas, a saída para trazer à tona suas memórias, cartas, notas, nas quais buscavam se defender de acusações e mesmo atacar uma situação ou personalidade. Aqueles, principalmente políticos, que tinham uma condição econômica mais avantajada, escreviam e mandavam publicar seus 
textos primeiramente em Portugal, no Brasil e às vezes na Índia, e eles depois eram distribuídos para o público do arquipélago.

Este dispositivo foi utilizado por Eugénio Tavares após ser acusado de apropriação indébita de dinheiro público, quando exercia cargo como funcionário da Fazenda na Ilha Brava.

Consciente das estratégias necessárias para denunciar os problemas de sua terra natal e para defender-se como cidadão, Eugénio personificava o perfil jornalístico adequado ao seu tempo, na ótica de João Nobre de Oliveira:

Era preciso que, para além de leitores mais esclarecidos, houvesse também pessoas que compreendessem a terra, que a interpretassem de um ponto de vista mais intelectual, quer através da análise política, quer através da literatura, que não se cingissem apenas as descrições folclóricas que isso qualquer estrangeiro de passagem também fazia e, muitas vezes, até melhor que os naturais. Ou sejam, eram precisos escribas que, conhecendo profundamente a terra, melhor pudessem expressar o seus anseios. Isto só seria possível com o aumento da instrução (1998, p. 69).

O estudioso aponta o papel da instrução do leitor como condição para o aparecimento de uma imprensa autônoma em Cabo Verde:

É inegável que, mesmo tendo um certo poder de compra, uma população analfabeta ou com um baixo nível cultural, não pode constituir um suporte para a existência de jornais autónomos, uma vez que não se interessará pela leitura daqueles. Ora, o aparecimento de um imprensa própria em Cabo Verde só trinta e cinco anos depois da introdução do prelo, para além dos factores económicos, é o reflexo do atraso da terra neste aspecto e da inexistência até então de uma população mais esclarecida e mais exigente em termos informativos, o que só seria possível com o aumento qualitativo da instrução (Ibidem).

O sucesso da luta pela implantação da instrução em Cabo Verde não se restringiria apenas às ações postas em prática pelo governo. Houve mobilização por parte de toda a sociedade, com a criação de associações culturais e grêmios com o fito de levar educação aos que não dispunham deste capital simbólico. É de se destacar também a iniciativa de cidadãos esclarecidos que dedicaram, de corpo e alma, parte de seu tempo a ensinar.

Segundo Manuel Brito-Semedo, após o surgimento do Boletim Oficial, “estavam criadas as condições para a implantação da imprensa não-oficial em Cabo 
Verde", uma vez que: i) havia a tipografia, ii) um público leitor com certa instrução e iii) uma elite letrada e culta, capaz de escrever para jornais e revistas (2006, p. 164).

Em resumo, o nascimento da imprensa em Cabo Verde "foi o resultado de uma combinação de factores técnicos. [...] no próprio solo cabo-verdiano formaram-se os leitores e os jornalistas que fizeram da imprensa cabo-verdiana um caso particular da África portuguesa" (OLIVEIRA, 1998, p. 115).

Como já ressaltado, o primeiro periódico não-oficial surgiu na Cidade da Praia, com o nome de Independente. Era tido como "jornal político litterário e commercial, dedicado aos interesses da província de Cabo Verde ${ }^{7 \%}$. Atribui-se sua fundação a Guilherme da Cunha Dantas e Joaquim Maria Augusto Barreto, ambos da ilha Brava, tendo a sua circulação durado aproximadamente doze anos, de 1877 até 1889.

A respeito da imprensa escrita cabo-verdiana, Leila Hernandez acrescenta que:

No seu extremo provincianismo, ainda que sedimentando particularismos e regionalismos, a imprensa escrita unifica interesses comuns. São sete os periódicos que passam a circular a partir de 1877 até 1886 , e começam paulatinamente a sugerir algumas reivindicações políticas, embora de forma tímida e, por vezes, ambígua. De todo o modo, a língua impressa acaba criando "campos unificados de intercâmbio e comunicação, [...] embrião da comunidade nacionalmente imaginada" (2002, p. 103).

Brito-Semedo expõe os anseios da elite culta e letrada cabo-verdiana nos momentos que precederam a chegada da imprensa ao arquipélago:

Mesmo antes de haver a instituição da imprensa em Cabo Verde, a preocupação da elite intelectual, de Hypolito da Costa Andrade a Eugénio Tavares e José Lopes, centrava-se na identificação do tipo ideal de jornalismo que conviria às ilhas. As posições defendidas por esses intelectuais eram coincidentes e, por vezes, complementares: um jornalismo independente dos poderosos e alheio à baixa política, que não fosse um repositório de lisonjas nem uma folha de "curcutição" (maledicência) e que concorresse para o levantamento espiritual do seu povo (2006, p. 165).

Hypólito da Costa Andrade, no texto intitulado “Instituição da Imprensa N'esta Província”, defendia que:

\footnotetext{
${ }^{7}$ Esta citação foi retirada do estudo feito pelo professor Manuel Brito-Semedo, que não informa a referência. Provavelmente o pesquisador a extraiu do número inicial d'O Independente.
} 
O jornalismo [que] sabe fugir ao domínio do espírito parcial das facções políticas, e não troca a sua magestosa independência pela degradante posição de instrumento de deshonestas ambições, de vinganças miseráveis, de desordem e desgraça dos povos, eleva-se nas abençoadas azas da felicidade de'elles à altura em que todas as classes generosas da sociedade o contemplam, filho da razão, amante da verdade, respeitador do direito, centro de luz, anjo de paz.

A imprensa que não queima à porta dos grandes das nações o incenso, cujo perfume suave se perde no thuribulo da adolação, sustentado em mãos de indignos (Boletim Oficial $\mathbf{n}^{\mathbf{0}}$. 46, 1871).

No que diz respeito aos jornais publicados em Cabo Verde logo após a proclamação da República, Eugénio Tavares, em uma de suas cartas (sob o pseudônimo Djôn de Mamai), explicitava seu conceito de "qualidade":

Um bom jornal não deve ser uma homilia, nem deve ser um cacete brandido por um possesso, nem repositório de lisonjas, nem folha de 'curcutição ${ }^{8}$. O jornal que se paga ao mister louvaminheiro de lamber tudo e todos, é uma coisa indecente; e um jornal que desanda à bordoada em tudo e em todos sem escolher onde nem em quem dá, também, é um estupor insuportável. Nem lamber nada nem morder muito (TVTCP, p. 173. "Cartas para a América", A Voz de Cabo Verde, n. ${ }^{\circ}$ 74, Praia, jan. 1913).

O posicionamento firme, de luta pela verdade e pela justiça, assumido por Eugénio Tavares ao longo de sua carreira jornalística, já se pode sentir com a publicação da Revista de Cabo Verde. Examinemos alguns excertos publicados no nº 2 desta revista, em março de 1899:

Pugnar pelos interesses da província, sendo, porventura, o mais simpático ponto de mira da REVISTA DE CABO VERDE, devia ser aquele que maior apoio lhe grangearia do público, se não fosse o que maiores tropeços lhe levantará, mal apareça à luz.

Porque, para que o público aplauda aquele que, serenamente, desassombradamente, vem apontar erros e propor emendas, é mister que esse público não pertença nem ao número dos que erram, nem ao dos que com o erro lucram. E, infelizmente, em Cabo Verde, os que não fazem parte duma ou doutra coisa podem, como diz o povo, contar-se pelos dedos (TPJ, p. 17, grifos nossos).

Sobre o modo como a imprensa deveria atuar, explicita Eugénio:

\footnotetext{
${ }^{8}$ Curcutição ou Curcutiçan é um gênero de arte popular praticado pelos camponeses da ilha do Fogo, em que os contendores se injuriam jocosamente, à desgarrada. Teixeira de Sousa, "Curcutiçan" (Recolhas Folclóricas), Cabo Verde - Boletim de Propaganda e Informação, n. ${ }^{\circ}$ 63, Praia, dez. de 1954, p. 18.
} 
não é necessário que o jornal envergue ares doutorais ou pedantescos: basta que, para realizar o fim que se propôs, tenha de abordar questões defesas, descobrir factos irritantes e expor verdades que, mais ou menos, firam susceptibilidades dos elevados às iminências da governança ou do dinheiro.

Não desanime, porém, o fundador da REVISTA; a atmosfera dos combates é o verdadeiro elemento do homem forte. Não pode haver triunfos sem que haja sacrifícios. E, a adversidade, é o rebolo onde os lidadores afiam o seu ânimo e temperam o aço da sua intransigência (Ibidem, grifos nossos).

Com base nessas concepções de jornalismo, os intelectuais cabo-verdianos assumiriam o dever cívico de produzir artigos para os periódicos da época, expressando seu ponto de vista acerca dos mais variados temas que os envolviam.

Nesse contexto, a importância de Eugénio Tavares (ou Nhô Génio Tavares, ou Nhô Tatai, como também era conhecido) pode ser avaliada pelos inúmeros epítetos que lhe foram atribuídos pela imprensa do arquipélago, ao longo do tempo, dos quais elencamos alguns deles: retratista incomparável da sociedade do seu tempo; polemista vigoroso; jornalista criterioso; príncipe dos jornalistas cabo-verdianos; pioneiro na defesa do homem cabo-verdiano livre e independente; publicista rigoroso; humanista combativo e mordaz; o primeiro a proclamar a autonomia para Cabo Verde; precursor do nativismo cabo-verdiano ${ }^{9}$.

De acordo com Tomé Varela da Silva, a produção esparsa de Eugénio Tavares, publicada em vários periódicos durante aproximadamente quatro décadas, permite

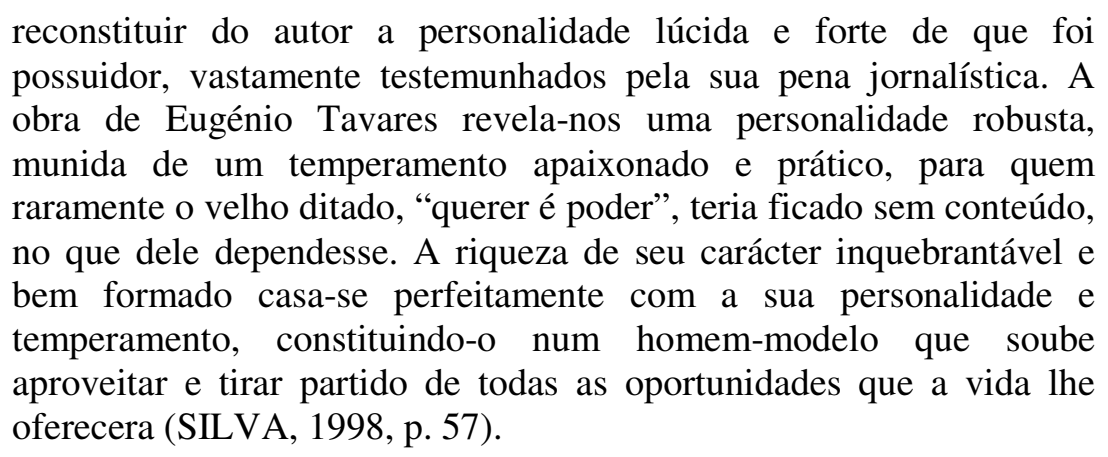

A imprensa, para ele, era uma forma de expor, cobrar, questionar, chamar a população - mesmo que apenas a parcela possuidora de alguma formação letrada - a refletir sobre todas as dificuldades que levavam Cabo Verde a se manter em inércia,

\footnotetext{
${ }^{9}$ Disponível no site da Fundação Eugénio Tavares www.eugeniotavares.com. Acesso em maio de 2010.
} 
face ao desinteresse das autoridades responsáveis diretamente pela administração das ilhas. A este respeito, criticamente, assim se manifestava:

Em qualquer recanto do mundo civilizado, é, o jornal, um drástico depurador: regula as funções do organismo oficial; purga-o de humores tóxicos; lava-o de impurezas; corrige-lhe os aleijões; lancetalhe os bubões; [...] entre nós, porém, a Imprensa mais não tem podido ser que uma firma desacreditada, uma infeliz às bolandas entre a fome quotidiana e a polícia correcional (TPJ, p. 148).

Alguns fragmentos dos textos jornalísticos tavarianos reforçam o que Tomé Varela da Silva ressalta na personalidade de Nhô Eugénio:

a atmosfera dos combates é o verdadeiro elemento do homem forte. Não pode haver triunfos sem que haja sacrifícios (TPJ, p. 17).

Eu exijo para o povo aquilo que, de direito, sei ser do povo (Ibidem, p. 25).

Quando não se tem sentimento moral, é claro, não se tem concepção do bem; quando não há concepção do bem, é fora de dúvida que não há iniciativa própria (Ibidem, p. 37).

Verdade, sempre verdade. Verdade a todo o transe. Verdade à custa da paz do meu lar, à custa do bem dos que amo, à custa da minha própria felicidade. [...] Verdade mesmo acima de Deus, se Deus não fosse para a Verdade o que o sol é para a luz (Ibidem, p. 58).

Todo aquele que, para conseguir um fim justo, lança mão de meios injustos, prejudica a realização da sua obra. [...] Nunca se chega ao bem trilhando a vereda do mal (Ibidem, p. 149).

Combate, moral, verdade e justiça, a serviço do "povo", constituem as linhas mestras do jornalismo tavariano.

Com efeito, no que toca à cidadania de Eugénio Tavares traduzida na sua produção jornalística, Tomé Varela acrescenta que:

foi um cidadão decidido e assumido em todas as circunstâncias e que elegeu o jornalismo (lúcido, porque lúcido, incómodo) como a sua arma predilecta de combate, dando voz a si mesmo, à sua ilha, a Cabo Verde, intervindo e denunciando, muitas vezes com evidente temeridade, todos os desleixos, atropelias, abusos e injustiças que espezinhavam os direitos, amarfanhavam os compatriotas, demoliam o patriotismo e impediam o desenvolvimento (SILVA, 1998, p. 57).

Quanto aos temas primordiais de seu macrotexto jornalístico, passamos a destacar alguns. 
Soluções práticas e eficientes para os problemas crônicos de Cabo Verde, como as crises de seca e fome, davam uma amostra do espírito combativo e empreendedor de Nhô Eugénio, quando ele endereçava artigos e missivas a "A vários cavalheiros respeitáveis que não lêem estas cartas":

Em 1903 se viu encherem-se valas de cadáveres, e [...] ainda se viu estertorarem-se na miséria Santo Antão e Boa Vista. [...] Não acham V. Exas. que já é tempo de se acabar com semelhantes vergonhas? Que deve ter soado a hora de os governos darem melhor remédio à hedionda lepra das traficâncias que a monarquia legou à República? [...]

Não entraram inda V. Exas. Na convicção de que a calamidade pública da fome deve ser atacada nas suas causas?

Não desconfiam V. Exas. de que possa ser tempo de pensar em exploração de nascentes? E regularizar sistemas de irrigação? $\mathrm{Na}$ utilização de todos os terrenos aráveis? No estudo de adaptação de novas culturas? No dever de tornar obrigatória a arborização? (TVTCP, p. 275).

Em virtude do abandono dispensado pelo governo colonial à sua terra-mãe, Eugénio Tavares apontou outra solução para o desenvolvimento de Cabo Verde: defendeu abertamente a emigração, principalmente para os Estados Unidos da América, país que era considerado por ele como o Eldorado onde se poderia alcançar a liberdade econômica e enriquecer culturalmente. Para Eugénio, a emigração cabo-verdiana constituía um elemento de riqueza e civilização (TPJ, p. 129).

A respeito da saída dos cabo-verdianos da terra natal, Leila Hernandez esclarece o contexto que a caracteriza, em certo sentido, como inevitável:

A precariedade da vida econômica e a extrema pobreza, a fome e a alta taxa de mortalidade, acentuadas nas épocas de secas, pragas e epidemias, expulsam amplos setores da sociedade para fora do arquipélago. [...] A aspiração básica do emigrante é lutar por sua sobrevivência e a de sua família para, num segundo momento, poder criar melhores condições de vida. Nesse sentido, o emigrante equaciona possibilidades de trabalho, levando em conta suas aspirações referentes à estabilidade do emprego, ao nível e à regularidade de remuneração e as possibilidades de ascensão profissional (2002, p. 104).

Ainda sobre a partida para a América, Eugénio Tavares, no artigo intitulado "A Emigração para a América”, afirma que:

A emigração cabo-verdiana para os Estados Unidos da América colocou, de há bastantes anos, a ilha Brava fora das contingências desoladoras da miséria com negra base nas irregularidades pluviosas 
características, peculiares à zona geográfica em que surgiu o arquipélago; e lhe ilustrou, e lhe puliu o seu povo; e a cobriu de habitações risonhas e confortáveis, recendendo ao aroma sadio e fresco do asseio holandês; e fez brilhar a consciência no cérebro do seu povo; e fez brotar a compreensão de uma sã moral que dignifica a atmosfera dos lares mais pobres; e cultivou o sentimento de amor ao lar, à família, sem o qual o amor à pátria, e os mais elevados sentimentos de civismo são utopias; e implantou o amor ao trabalho, à independência; a coragem moral que vence todas as dificuldades, o desprezo da morte que facilita todas as empresas (TPJ, pp. 163-164).

Lembremos que o tratamento da temática da emigração por parte de Eugénio Tavares não se restringiu ao campo do jornalismo, mas teve destaque também na sua epistolografia e na sua poesia. E o intelectual ateve-se ainda a outras formas de emigração, nem sempre concebidas como tão positivas, que estabeleciam um contraponto com a partida para a América. Observemos a mestria com que trata o assunto sob a forma erudita culta do soneto:

\section{A Emigração}

(A propósito da emigração para S. Tomé e Príncipe)

Como é triste e é desolador,

Ver partir, aos magotes, esta gente, Entregue ao seu destino, indiferente A tanto sofrimento, tanta dor!

Se a sorte ainda a traz à terra amiga, Macilenta, tristonha, depaup'rada, Com a doença do sono, já minada, Ao cemitério um só coval mendiga!

Mas porque ides, assim arrebanhada, A essa maldita terra de desterro? É a fome que vos leva acorrentada?

\section{Aproveitai melhor a mocidade $\mathrm{E}$ ide mais distante, ide à América A terra do trabalho e liberdade!}

Os dois tercetos corroboram o que Eugénio Tavares denunciava no número dois da Revista de Cabo Verde: "Realizam-se emigrações em massa; e, mercê do desprezo da metrópole, está-se operando uma radical desnacionalização do povo caboverdiano, principalmente dos naturais da ilha Brava" (TPJ, 1997, p. 18). A emigração para São Tomé é encarada como "desterro" e como não-trabalho, semelhante à 
escravatura. Somente em liberdade o ser humano pode realizar trabalho digno, é a máxima proposta por Nhô (Mestre) Eugénio e este tipo de emigração não traria rendimentos aos emigrados, muito pelo contrário, embrutecia-os e empobrecia-os.

José António Nobre Marques Guimarães, em O Nativismo em Eugénio Tavares (2005) lembra que um dos fios condutores da ação política e jornalística do poeta, desde cedo, ergue-se contra a contratação de serviçais para São Tomé. Este trabalho, pesado e muito mal remunerado, era destinado aos cabo-verdianos que a ele se submetiam em virtude do estado miserável em que viviam, uma vez que não tinham outra alternativa diante das sucessivas secas que assolavam o país e que causavam grande caos social. Havia, ademais, interesse por parte da administração colonial em se aproveitar desse cenário de calamidades, já que desta forma o governo português conseguia mão-de-obra quase gratuita para o trabalho nas plantações de cacau em São Tomé.

Desmontando alguns argumentos do Sr. Leote do Rego a favor da mão-de-obra cabo-verdiana para São Tomé, expressos em entrevista intitulada "Pela Imprensa do País", concedida ao jornal O Século, de Lisboa, Eugénio vai refutar enfaticamente esta forma de emigração usando o texto jornalístico como arma. Confrontemos as idéias do Sr. Leote, citado em artigo-réplica tavariano:

para que o desenvolvimento da agricultura em S. Tomé não sofra entraves, não lute com dificuldades por causa da falta de braços, é isto que se deve procurar manter; não por leis violentas mas por meios suaves de captação. Angola tem-nos faltado ultimamente com homens, em virtude dos ingleses; Cabo Verde, apesar de gritar com fome, faz outro tanto e necessitamos estudar a sério um problema grave como é este. Ora, poder-se-á resolver favoravelmente os nossos interesses em S. Tomé, conseguindo-se esta espécie de andamento rotativa: o preto depois de ver a sua terra voltar para as roças por sua livre vontade" (REGO citado por TPJ, pp. 90-91, grifos nossos).

Eugénio Tavares reagiu prontamente, destacando os pontos a seguir.

\section{- “Não por leis violentas":}

Perfeitamente ociosa a sugestão. Isso, hoje, não se faz: João Franco não governa; dá leis a República; e a República não tolera violências de ordem a se admitir suposição de escravatura; e os homens que a dirigem jamais se prestarão a barrar os alicerces da Liberdade com sangue e lágrimas de outros homens, sejam eles pretos de Angola ou mestiços de Cabo Verde. De resto, mesmo admitindo que a agricultura de $\mathrm{S}$. Tomé só pudesse florescer pelo sistema da violência, isto é, pela escravatura, há um interesse que fala mais alto que as prosperidades 
materiais de um país: a intangibilidade dos direitos sociais do indivíduo. E o preto, por ser preto, não é possível negar-lhe direitos. (Ibidem, p. 91).

\section{- "Por meios suaves de captação":}

Também isso não se deve fazer.

Captação é o emprego de meios capciosos; é a astúcia para induzir ao erro; é a promessa dolosa, falsa, fraudulenta, cavilosa. É estender redes besuntadas com o visco de promessas que nunca se cumprem. É um crime. À democracia repugnam tais meios.

Existe, porém, um meio de evitar que o desenvolvimento da agricultura em S. Tomé sofra entraves: é atrair trabalhadores - não arrebanhar escravos! - dando-lhes salários, instrução, direitos. Do contrário é contar que, Cabo Verde, não irá para S. Tomé um único homem que não leve o desprezo do povo cabo-verdiano (Ibidem).

\section{- "Cabo Verde, apesar de gritar com fome..."}

Em Cabo Verde, é facto, tem-se morrido à fome. Sob o governo do sr. Cid - Hoje, também, republicano! - vinte mil miseráveis foram atirados à vala. A cada passo se encontram, em Cabo Verde, homens que morrem sem uma queixa; mas é difícil encontrar um preto ou um mestiço que suportem a chicotada de um comitre sem responder com essa criminosa energia, à qual, raro sobrevivem os que vibram o chicote e o ultraje.

Já se tem experimentado.

O cabo-verdiano tem esse grande defeito de se não prestar a um certo número de trabalhos (Ibidem).

Diferentemente da emigração forçada para São Tomé, outros destinos, como a

América, podiam educar e enriquecer, trazer progresso moral, material e intelectual.

N'A Voz de Cabo Verde, Ano III, n. ${ }^{\circ}$ 101, de 21/07/1913, no artigo intitulado

"Questões Económicas: A emigração cabo-verdiana é um elemento de riqueza e de civilização", o jornalista bravense destaca que o homem cabo-verdiano, em tipos de emigração como as da ilha do Fogo e da Brava para a América, vai

quase sempre sem instrução, com apenas aquela educação que bebeu na pobre e honesta atmosfera em que nasceu. Quando volta porém, ele, que tinha ido um pária, chega um cidadão. Traz dinheiro, traz uma definida concepção moral, vem fazendo uma ideia aproximada do direito, do dever, da justiça; de modo que a sua casa progride, a sua prole educa-se, a sua existência dignifica-se. E os seus descendentes, ele mesmo, jamais poderão ser os servos que engraxam as botas e lisonjeiam as vaidades dos senhores. Os resultados da emigração cabo-verdiana podem-se ver no Fogo e na Brava, onde ela tem frutificado. Em nenhuma das outras ilhas há, ainda, uma emigração 
regulada, estabelecida e com resultados evidentes, incontestáveis, que se ofereçam como provas contra o oco farelório dos coloniais (Ibidem, p. 130).

Por exemplo, o artigo "Emigração para a América", A Voz de Cabo Verde, n. ${ }^{\circ}$ 35, 15/Abr/1912, ressalta o progresso alcançado pelos emigrantes da Ilha do Fogo que se estabeleceram nos Estados Unidos da América e estendem à sua terra natal o desenvolvimento trazido da diáspora:

Os grandes morgadios serra-mar, ainda na sua maior parte negligentemente, primitivamente cultivados, quase que abandonados a um pousio esterilizador, começam, hoje, de ser subdivididos em herdades pequenas, em talhões de pobres que os cultivam com esmero e com amor; confiados, por longos anos, aos cuidados mercenários dos rendeiros ou meeiros sem ciência agrícola, passam agora a ser lavrados por aqueles que não só pensam na maneira de fazer a colheita anual, senão na possibilidade de seus filhos e netos virem a colher no futuro (Ibidem, p. 164, grifos nossos).

Uma nova sociedade passa a ser implantada com o regresso daqueles que partiram. Desta forma, o progresso da Ilha Brava é assim relatado em 1912:

\begin{abstract}
A Brava, a mais pequena da ilhas de Cabo Verde, apresenta-nos o exemplo do trabalho, da perseverança, da dignidade moral que se assimila na América. As suas montanhas elevadas, os seus vales deliciosos, os seus planaltos oxigenados, povoaram-se de habitações confortáveis e risonhas, onde a felicidade e a abastança nem sempre dependem das circunstâncias pluviosas. O seu povo é civilizado. A organização da família é regular. Nos anos de crise alimentícia, de irregularidades pluviosas, sete por cento da população carece de socorros públicos. O resto tem a sua vida garantida pelo seu trabalho fora (Ibidem, p. 130).
\end{abstract}

Em correspondência especial do jornal português A Marselhesa, em 1897, Eugénio Tavares antes denunciava ao Secretário da Fazenda o abandono da sua ilha natal e, por extensão, da colônia, assim como a responsabilidade do Estado colonial:

Suba o Sr. Secretário aos formosos platôs da ilha Brava e pergunte ao baleeiro esquálido, amofinado pela fome, entristecido pela contemplação dos seus campos varridos pela lestada, embrutecido [...] - que é da beleza das suas montanhas e da abundância dos seus vales; que vento de morte lhe levou os filhos e a alegria doméstica; quem the esvaziou as tulhas e lhe levou os granéis; quem o amarra à miséria em terra e lhe fecha o caminho da abundância no mar [...].

Foi a preguiça?

A invalidez?

As doenças? 
Não. Foi o Estado (Ibidem, p. 14-15, grifos nossos).

No artigo intitulado "Questões Económicas", publicado em A Voz de Cabo

Verde, Eugénio declara que o cabo-verdiano "não lança raízes às terras para onde vai trabalhar, mas lá "vai procurar seiva para aprofundar e fortalecer as raízes que deixou nas suas ilhas". E sintetiza:

Não se percam, pois, de vista, estas verdades: a emigração, em Cabo Verde, é um bem. Contrariar a emigração cabo-verdiana para os Estados Unidos da América é favorecer a decadência da província, é abrir um futuro de miséria e sofrimentos aos cabo-verdianos (Ibidem, p. 131).

Com efeito, para a professora Leila Hernandez, a emigração constitui um processo psicossocial que ajuda o emigrante a se desvencilhar de normas internalizadas ao longo de séculos de dominação:

com o impacto da vida urbana e da educação moderna às quais são expostos, os emigrantes transformam-se em grupos de pressão, reivindicando transformações e almejando ampliação da participação política, desenvolvendo o espírito crítico acerca da estrutura vigente e da falta de liberdade em que vivem no arquipélago. Seus horizontes ampliam-se assim cada vez mais. (2002, p. 107).

N'A Voz de Cabo Verde, Eugénio Tavares continua a defesa da emigração dos cabo-verdianos para os Estados Unidos como uma das soluções para os problemas da colônia. Em carta escrita em junho de 1918, dirigida a D. Alexandre D’Almeida, intitulada "Noli me tangere", o autor pontua e analisa o tema e suas consequiências. Ao refletir sobre o processo emigratório, Eugénio Tavares consolida veementemente o discurso crítico, aponta os motivos que levam os cabo-verdianos a deixar a terra natal e ainda destaca os pontos positivos para aqueles que rumavam à América:

$1^{\circ}$. - O caboverdeano não vai à América apenas à cata de alimento; $2^{\circ}$. - $\mathrm{O}$ caboverdeano, quando regressa, (pois que sempre regressa quem como ele ama a família e a terra em que nasceu) traz, não só dollars, senão luzes; e apresenta, não só um exterior de civilizado, mas uma noção social por vezes mais justa que aquela que de outra parte lhe seria impossível trazer; $3^{\circ}$. - Que o caboverdeano, na América, modifica o seu modo de ser moral, erguendo-se de um absoluto anonimato social e consciente elemento de progresso; $4^{\circ}$. - Que, açacalado no contacto do grande povo americano, o caboverdeano aprende a encarar a vida por um prisma elevado; cria necessidades que lhe educam a vontade em lutas mais nobres; integra-se na civilização, já se não adaptando dentro da estreita exigência da cubata e da cachupa; já dificilmente suportando as exigências tirânicas de um trabalho humilhante e mal remunerado, facto que por mais de uma vez 
o contra-indicou para as encomendas de forças fiscais periodicamente facturadas para São Tomé e Príncipe; 50. - Que, finalmente, o caboverdeano pertence, como todos nós sabemos, a esse número de homens cujas aspirações não se limitam à actividade mandibular. (TVTCP, pp. 229-230).

Em suma, não se resumem às necessidades de sobrevivência os motivos para a emigração. O fenômeno é mais complexo. Corsino Fortes (2002, p. 3), desdobrando o tema, observa que:

Entre a insularidade e as estiagens, a emigração é outro fenómeno característico da vivência do homem do arquipélago. Eugénio Tavares referencia nos seus trabalhos dois tipos de emigração: a emigração desejada e a expontânea (sic.), com o início no final do sec. XIX, nomeadamente das ilhas do Fogo e Brava para os Estados Unidos da América, e a emigração compulsiva, no início do sec. XX, para Angola e S. Tomé e Príncipe. Esta emigração é diferente da expontânea porque se baseia no desespero de uma população que, flagelada pelas secas, desemprego, miséria e fome, é incitada pelas pressões administrativas a ir trabalhar mediante contratos de miséria que geralmente não são cumpridos (FORTES, 2002, p. 3).

No entanto, há quem discuta, como Leila Hernandez, que a saída do caboverdiano por iniciativa própria, sem constrangimentos institucionais, seja considerada espontânea, uma vez que "é causada por alto grau de dificuldade econômica. É assim, desde o primeiro grupo do qual se tem registro, que nos últimos dez anos do século XIX parte da ilha Brava, em navios baleeiros, como destino aos Estados Unidos" (HERNANDEZ, 2002, p. 104).

Fátima Monteiro contemporiza, aliando-se às propostas de Eugénio e Corsino:

O impacto da emigração para a América é sentido, deve salientar-se, não só de um ponto de vista social e económico. Ele faz-se sentir igualmente ao nível da cultura e dos valores, já que aquele que partia regressava mais letrado e cosmopolita do que saíra, e trazia consigo, além do mais, os paradigmas culturais e políticos de um país rico e desenvolvido ${ }^{10}$.

Resume Eugénio Tavares na carta "Noli me tangere": "A emigração é um bem; é um factor de progresso cabo-verdiano; é um campo insubstituível aberto à nossa actividade [...], não há que evitá-la, senão fomentá-la [...], devemos defendê-la, não atacá-la" (TVTCP, p. 232).

\footnotetext{
${ }^{10}$ Disponível em: http://www.ieei.pt/files/Cabo_Verde_encruzilhada_atlantica_Fatima_Monteiro.pdf. p.
} 4, s/d. Acesso em maio de 2010. 
Paralelamente ao capital cultural acrescentado ao patrimônio cabo-verdiano pela emigração, Eugénio defendia a melhoria do nível de instrução na colônia .Era necessário o acesso indiscriminado à instrução formal, a formação de um público leitor e a fragilidade do sistema escolar cabo-verdiano travava esse desenvolvimento. Ao escrever artigos jornalísticos acerca da necessidade de difusão da educação, o intelectual exigia das autoridades portuguesas escolas para o povo, em tom de quase ameaça:

Eu não peço aquilo que, posto que me tenha sido negado, por direito, meu, exijo. [...]

Eu exijo para o povo aquilo que, de direito sei ser do povo [...].

Quereis saber quem sou eu para exigir? Sou uma vontade e, por conseguinte, uma força.

Negam a luz ao povo, porque a instrução na alma do povo é como um feixe de raios em mãos de arcanjos.

É tempo de se convencerem todos, de que dar escolas e estradas ao povo não é um favor que se lhe faz; é uma dívida que se lhe paga.

Por isso exijo; não peço.

Não hei-de pedir pedindo, disse o padre António Vieira, senão protestando e argumentando; pois esta é a licença e liberdade que tem quem não pede favor senão justiça (TPJ, pp. 24-25).

No artigo "Versando o Ensino Público", entusiasmado com a publicação no Boletim Oficial n. ${ }^{\circ} 41$ da circular n. 27 da Secretaria Geral, que convocava uma reunião de presidentes e delegados de corporações municipais para discutir a remodelação e desenvolvimento do ensino primário na província, Eugénio Tavares cumprimentava a iniciativa do governador e se animava com o futuro do ensino nas ilhas. Considerando a iniciativa como digna de louvor, acrescentava: "Nós, de nós, nos não pouparemos ao dever de cumprir, nesta campanha, nossa missão de jornalista, colaborando, na medida das nossas forças, nessa obra” (Ibidem, p. 198).

Eugénio relembra, nesse texto, a sua luta em prol do direito cabo-verdiano a instrução de qualidade:

Há muitos anos que nos batemos pelo aperfeiçoamento do ensino na província.

Já em colunas de jornais, já em opúsculos, arrostamos, em prol da instrução, com os então perigosos escolhos da discussão pública, num meio onde discutir era sempre ferir...

Em toda essa longa campanha, porém, mais não conseguimos colher que ferimentos mais ou menos fundos, dos quais ainda hoje enfermamos gravemente. Nem vimos o êxito coroar a causa que defendíamos, nem tão pouco enxergamos a glória lisongeando o sacrifício que fazíamos entrando nessa cova de leões da discussão 
pública, num meio onde a prosápia, de sobrecenho carregado, exagerava a sensibilidade até estatelar-se no ridículo.

Porque, afinal, naqueles tempos (1900 a 1910) a honra só se abraçava ao êxito, e o êxito só premiava trabalhos de sapa nos quais a lisonja tivessem lubrificado as vontades soberanas, propiciando ânimos e desvirtuando as linhas do interesse público (Ibidem, p. 198).

Ressaltando a importância que países como Japão, Suíça, Estados Unidos dispensam aos sistemas educacionais, Eugénio Tavares apela ao governador para que:

Atenda V. Exa. às somas relativamente enormes que, com tanta coisa inútil, são, aqui, anualmente, dispendidas; e pense, a que grau de elevação moral e intelectual estaria erguida a província, se parte desse dinheiro fosse gasto com a instituição, em todas as ilhas, de escolas primárias e secundárias regidas por professores competentes, e dotadas de casas e mobiliário higiénicos, decentes.

Gasta-se loucamente com todos os ramos do serviço público; e para a instrução apenas vão umas tristes migalhas, mal escorrem aguadas gotas de sangue ao contribuinte! (Ibidem, p. 200).

E chama a atenção para a pouca eficácia do ensino sob responsabilidade municipal, ao afirmar:

Bem pouca gente pode ignorar que, no ensino municipal (com excepções), se é certo que as coisas se não passam, rigorosamente, da mesma maneira que nas piores escolas do governo, é incontestável que também não correm pela melhor forma. Antes, notório é que o desleixo de uns, correndo parelhas com a tolerância de outros, tudo tem feito para que as escolas cabo-verdianas tanto se pareçam com asilos de professores (Ibidem, p. 200).

Nesse contexto, era previsível que os cidadãos cabo-verdianos tivessem pouca atuação política, já que não lhes era facultado o direito máximo de conscientização pela via da instrução.

Nos Estados Unidos da América, em 1900, Eugénio Tavares ("Português de lei! Cabo-verdiano de alma!" (TVTCP, p. 175) cria o jornal A Alvorada e, em agosto do mesmo ano, demonstrando espírito polêmico e precursor, publica o artigo intitulado "Autonomia", manifestando-se contrário à ameaça de venda das colônias e conclamando a necessidade dos cabo-verdianos e demais colônias não se curvarem "servilmente aos escuros destinos de Portugal", a "mais negra escravidão", organizando-se em partidos: 
Em todos os países onde a liberdade tem culto; onde, ainda o miserável que fadeja pelas últimas camadas sociais, alimenta, no mais íntimo do peito, o sagrado sonho da independência; onde os filhos pensam na maioridade e promovem à constituição do seu home; em toda a parte onde há homens que, sem envergonhar a humanidade, podem usar o nome de homens; dedica-se um bocado de tempo, consagra-se uma parcela de talento ao culto da independência (TPJ, pp. 68-69).

O jornalista Eugénio Tavares não se conforma com a falta de iniciativa dos povos das colônias portuguesas na África, por não tomarem uma atitude mais incisiva na busca por autonomia de um regime que considera "de sujeição" (Ibidem, p. 174). E reprova essa atitude com a mordacidade da ironia, dando ressalto à intervenção política como condição para o desenvolvimento:

Nas colónias portuguesas, porém, quase se não pensa ainda nessas bagatelas. É verdade que, Madeira e Açores, tiveram pelos beiços esse mel de ilhas adjacentes, um osso para enganar a fome de independência. Cabo Verde, Angola e Moçambique porém, é que ainda não pensaram nessas futilidades.

Dá tanto trabalho!

E depois as responsabilidades! É tão bom a gente não as ter! Felizes os que têm quem lhes governe a casa. Comem um bocado em descanso; dormem um sono sossegado (Ibidem, p. 69).

A ironia é a estratégia escolhida contra o que considera "comodismo" dos irmãos africanos. E a permanência desse status quo pelos filhos dos colonos é veementemente criticada:

O português dessas duas riquíssimas províncias não cai na asneira de ser angolense nem moçambicano: é simplesmente português.

Trata de ir a África ganhar dinheiro; não se rala com cuidados de dar uma pátria a seus filhos nascidos na África. Está ainda longe de sonhar um Washington. [...]

Ganha dinheiro e vai gastá-lo a Portugal. Em vez de fazer um palácio em solo onde os seus filhos brincaram, onde ele semeou e colheu, vai fazer um chalet nas aristocráticas praias de Portugal onde o seu dinheiro vai ser o engodo de falsas considerações e a sua ignorância o pábulo da proverbial risota portuguesa.

Os cuidados de uma pátria perturbam a digestão dos Santo Antoninhos da fortuna nas Áfricas portuguesas. [...] Assim é que, em quase todo o ultramarino português, muito raramente se pensa em criar um partido autonômico (Ibidem). 
A incapacidade do governo português na administração das colônias e a ameaça das grandes potências sobre sua autonomia serão evidenciadas na pena do jornalista cabo-verdiano no exílio:

Portugal vende, cede, na sua dadivosa miséria, os terrenos do Ultramar. As nações sedentas de expansão comercial, absorvem-lhe tudo. Parvo, deixa-se sempre enganar; fraco, deixa-se sempre intimidar.

Portugal não deve fazer isso. Não basta, porém, que o não deva; é mister que nós, os filhos das Colónias, levantemos um obstáculo intransmontável à prodigalidade desse velho dissipador. Esse dique é a nossa emancipação. Essa parte da herança pertence-nos. A África portuguesa não quer que Portugal a dê de presente a estrangeiros (Ibidem, p. 70).

Como se percebe do fragmento, Eugénio sentia, naquele momento (1900), o imperativo de criação de um partido autônomo: "Portugueses-irmãos, sim: Portuguesesescravos, nunca. Havemos de ter o nosso Monroe: A África para os africanos” (Ibidem).

O jornalista, glosando frase célebre do revolucionário americano, conclama a necessidade da liberdade de Cabo Verde ao mesmo tempo em que estende esse debate a todas as colônias: “[...] clamando a África para os africanos, este é o seu primeiro apelo à independência de Cabo Verde”, enfatiza Corsino Fortes (2002, p. 02).

Segundo João Nobre de Oliveira, com o lançamento do jornal A Alvorada, nos Estados Unidos, Eugénio Tavares:

terá iniciado assim um tipo de jornais que, ainda que com uma circulação limitada, incomodavam o poder político instalado. A diáspora cabo-verdiana, principalmente quando radicada em países com regimes democráticos, continuará a suportar jornais que, longe, tanto do poder dos governadores como do próprio governo português, - livres da censura portanto - denunciarão os problemas e atacarão os políticos locais (1998, p. 213).

$\mathrm{Na}$ altura em que vem à baila a discussão sobre a venda das colônias portuguesas na África, em função do Ultimatum Inglês, Eugénio Tavares publica textos expressando a sua opinião e apontando as consequências que tal iniciativa poderia gerar para Cabo Verde. O artigo "Pregar no Deserto", publicado no n. 3 da Revista de Cabo Verde, é peça destacada da sua recusa à transferência de domínio das colônias: 
não hesito afirmar que é grande erro esperar que, sob a dominação de qualquer das grandes potências civilizadoras, que sobre nós estendem vistas cobiçosas, mais claros horizontes se nos abrirão.

[...] As libras inglesas poderão reflorir as nossas devezas e engrinaldar as nossas escalvadas montanhas de luxos primaveris; porém, - ai de nós, - o nosso sorriso puro de pobres livres crestar-no-lo-á o aspérrimo desprezo dos novos senhores; e, esses amáveis ingleses da portuguesa ilha de $\mathrm{S}$. Vicente, esses simpáticos rapazes que, hoje, de sorriso em riste, em toda a ruidosa bizarria que os caracteriza, nos distribuem os seus efusivos shake-hands, passarão, amanhã, dominadores, na inglesa ilha de S. Vicente, a envolver-nos, lá do alto do seu orgulho saxão, no mais frio e acabrunhador desdém.

E esse desdém, - digamo-lo bem alto para que nos ouçam aqueles que mais alto estiverem, porque não falamos ao povo analfabeto, irresponsável, sem noções de patriotismo que há-de, de braços abertos, receber quem lhe traz luz e pão, e não há-de estranhar o chicote, habituado como está à espora (TPJ, pp. 20-21).

O assunto voltará a render um outro texto, no n. ${ }^{\circ} 4$ da Revista, desta vez com título explícito, "A Venda das Colónias", e demonstra um Eugénio Tavares indignado com as autoridades portuguesas que cogitavam tal afronta aos cabo-verdianos:

A venda efectuava-se mas em circunstâncias que tiravam de sobre os ombros de quem a realizava, todo o peso desse crime de vender irmãos. Os homens do governo tinham passado a ser estrangeiros; de modo que ao tempo de negociar a venda das colónias, já não eram portugueses; assim deixava de lhes tocar o labéu de vender a própria pátria (Ibidem, p. 27).

Eugénio Tavares encerra o seu artigo praticamente conclamando angolanos, moçambicanos e cabo-verdianos a ficarem atentos aos acontecimentos vindouros e a não aceitarem ser vistos como meros artigos que se compra e vende sem a menor consideração. "Aguardemos os acontecimentos e vejamos se os portugueses de Angola, Moçambique e Cabo Verde estarão dispostos a aceitar essa classificação de artigos de factura" (Ibidem, p. 29).

Mostrando-se atento ao desenrolar da questão da venda das colônias, um novo artigo é publicado no n. ${ }^{\circ} 6$ da Revista de Cabo Verde, em maio de 1899, cujos pontos mais importantes reproduzimos:

O imenso império descoberto e conquistado por aqueles extraordinários portugueses que assombraram o mundo com a homérica audácia dos seus cometimentos, vai ser retalhado pela desmedida ambição das nações do Norte. 
O leopardo inglês e a águia negra da Prússia tramam, nas labirínticas sombras da política, o roubo e o saque dum povo pequeno e sem forças para se defender.

É ignóbil, mas é verdade. [...]

A política passou para os domínios de uma aperfeiçoada arte de furtar! A força é que é verdadeiro direito. $O$ direito não passa de uma bonita utopia, sonho de poetas, preocupação asnática de visionários! [...]

Fabricam-se documentos falsos com que provar prioridade de descobrimentos e ocupações; inventam-se pretextos fúteis que levem directamente, incisivamente, à posse violenta de propriedade alheias. [...] o plano concertado entre a Alemanha e a Inglaterra não visa só a partilha da África portuguesa; é uma guerra à raça latina: contra a península hispânica que consubstancia toda a sublimidade artística dos tempos idos; e contra a França, o foco da Civilização e alma de todo o Ideal pelo homem (Ibidem, pp. 32-34).

Eugénio atacava um provável desmembramento das colônias portuguesas na África, posicionando-se contrariamente a posturas dos Estados Unidos, da Inglaterra e da Alemanha, uma vez que, no seu entendimento, esses países haviam declarado guerra aos países de origem latina (Portugal, Espanha, Itália e França). A ambição das grandes potências européias em relação às colônias foi motivo constante de preocupação expresso nos textos tavarianos, como "Política Colonial", publicado no n. . 27, de A Voz. de Cabo Verde, em 1912:

Fora de dúvida que o povo colonial português jamais seria consultado sobre se aceitaria, ou não, qualquer dominação estrangeira; [...] e o povo do ultramar, devendo ter, como teria, sob o domínio de qualquer potência estrangeira, direitos ao par de deveres, força política constituída, poderia, até certo ponto, agir, senão de modo a evitar o esbulho violento, pelo menos de jeito a perturbar a posse, a não sancionar o crime com a ausência de protestos insurreccionais.

Não é o interesse da civilização que está arremessando os povos poderosos a essa desenfreada pirataria de mutuamente se roubarem, se despojarem de terras ultramarinas; senão que, evidentemente, o sórdido egoísmo, a fome dos lucros comerciais e industriais, a irrefreada ambição das hegemonias políticas. Não é para civilizar, mas sim para servilizar que a Alemanha se está atirando à voragem das aventuras africanas. [...]

Do pele-vermelha, na América, pouco mais se vê, hoje, que fragmentos erráticos de tribos dizimadas, dispersas pelas largas planuras do oeste, saudosos depositários das tradições de heroísmo dos seus grandes e temíveis chefes. [...] Semelhantemente, ao preto africano - se se não instrui, se se não impõe pelos seus direitos, o mesmo destino o espera: tem os seus séculos contados (Ibidem, p. 95, grifos nossos).

Eugénio Tavares enfatizava o desdém com que vinha sendo tratado o homem das colônias: 
O indígena das colónias, até aqui, tem sido uma grande força nacional relegada ao mais estúpido desprezo; facto que é não só um crime à face das leis sociais, mas também um procedimento político irreflectido, incongruente, da parte dos governos da nação (Ibidem, pp. 96-97).

Por outro lado, na Revista de Cabo Verde, Eugénio trazia ainda à estampa um artigo no qual discorria sobre o que considerava a índole "pacífica" dos cabo-verdianos e sobre o excesso de "prudência" que a norteava, como causas, em parte, da permissividade das situações anteriormente descritas:

É, pois, a prudência cabo-verdiana, mais um irreflectido receio de afrontar males que podem, mais ou menos facilmente, ser vencidos, que uma serena experiência de evitar um golpe sem deixar alvo a maior golpe; mais um instinto de conservação pessoal, que leva cada qual a cuidar de si, que juízo esclarecido, que avisada previdência de evitar combate e prevenir, com maior firmeza, a defesa colectiva; mais egoísmo, em suma, que prudência. (Ibidem, pp. 22-24).

Para o autor, o excessivo apego à prudência levava ao não-comprometimento coletivo e à abdicação de direitos garantidos. No artigo "Asilos", por exemplo, Eugénio Tavares denunciava a prática da mendicância (tema retomado por contos de outros escritores cabo-verdianos, como "Esmola de Merca", de Orlanda Amarílis, e "Sábado Nossa Senhora", de Ivone Aída), durante uma das várias crises que afetaram a cidade da Praia; denunciava ainda o imobilismo dos governantes face àquela prática:

É aos sábados que o pungente espectáculo da sua exibição se alastra, numa enxurrada, pelas ruas da cidade. Os seus andrajos, as suas deformidades, compungem e amarelecem a alegria de viver. De mãos estendidas, gemebundas, súplices, apinham-se pelos portais, amontoam-se pelas ruas, escoam pelas vielas, envolvendo a todos na atmosfera da sua dor, oferecendo ao forasteiro um espectáculo que não mais se apaga do seu espírito. Oh, aos sábados, a enchente de mendicidade que inunda as ruas da Praia lembra as páginas horripilantes do Triunfo da Morte, de Gabriel d'Annunzzio: entristecem, golpeiam, torturam, e dão a medida do desleixo dos governos do ultramar, e dão uma prova de quanto são singulares, extravagantes, incompletos, não só as noções da bondade que formam, imperfeitamente, o fundo no nosso carácter, senão que o sentimento da dignidade humana, e, mais ainda, o sentimento da nossa própria dignidade nacional (Ibidem, p. 120, grifos nossos).

A indignação com o descaso português em relação às suas colônias na África era tamanha, a ponto de Eugénio compará-la com o modelo de colonização praticado pela Inglaterra: 
acreditamos na superioridade do povo inglês no campo da grande ciência colonizadora. Como a Inglaterra, com iguais justiça, critério, extensão de vistas e resultados práticos, nenhum país ainda colonizou. (Ibidem, p. 159).

Diferentemente do modelo português, que apenas explorava as riquezas dos territórios sob seu domínio, a forma de colonização inglesa, segundo o jornalista, transformava os habitantes dos territórios colonizados em cidadãos tão ingleses quanto eram os naturais:

\begin{abstract}
A Inglaterra, sempre que tomava posse de terras descobertas ou conquistadas, muitas já descobertas por outros que nos feitos marítimos tiveram a glória de ser os primeiros, plantava-lhes, nos solos virgens e opulentos, a liberdade e o bom senso da sua maravilhosa política. Assim progrediram a Austrália, a Nova Zelândia, o Cabo, o Canadá, os Estados Unidos. [...] A Inglaterra é uma família de homens independentes e livres, vivam os seus nacionais no país em que viverem, tenham a cor que tiverem. Os povos ingleses semelham filhos que casam, fazem casa e constituem família. [...]

Colonizar é isto: ter filhos, não escravos... [...]

São ingleses os louros filhos da Europa, os escuros africanos e os bronzeados dos índios. Todos com direitos, todos com deveres. Todos livres, todos olhando o futuro com plena confiança no seu destino. (Ibidem, pp. 159-160).
\end{abstract}

Eugénio concluía o artigo com um pedido que, infelizmente, parece não ter sido ouvido pelos colonizadores portugueses: “[...] praza a Deus que o grande exemplo da Inglaterra frutifique..." (Ibidem, p. 161).

Retomando a temática sobre o "caráter ou personalidade" do homem caboverdiano, como concebido por Eugénio Tavares, vale ressaltar o texto "Os indígenas de Cabo Verde são desleixados, indolentes e bêbados?", no qual (apesar de em outro artigo ter-lhes uma "índole pacífica" e um "excesso de prudência") fazia a defesa dos seus compatriotas face aos juízos de valor feitos pelos europeus, especialmente aqueles que ocupavam cargos administrativos.

Chega a causar dó a facilidade, a insensatez e o desplante com que se atribui ao desleixo ou indolência indígena todos os males que provêm do indiferentismo e imprevidências governativas.

Esse pouco escrúpulo e, quiçá, essa má fé com que se costuma desvalorizar a actividade dos filhos de Cabo Verde, só têm servido para desnortear os legisladores que não conhecem o indígena de Cabo Verde (Ibidem, p. 106). 
Tavares argumentava, em defesa dos naturais do arquipélago, que:

Se estes fossem desleixados e indolentes, não emigravam à procura de trabalho fora da sua terra, nem seriam recebidos nos E. U. da América do Norte; antes, seriam recambiados à terra que os exportou.

Isto está a par desse outro estribilho de que muito têm usado e abusado alguns doutores, em seus maçudos relatórios: o preto não pode passar sem aguardente; ou o preto sustenta-se de aguardente.

Ora, se ele não pode passar sem aguardente, como é que se explica a sua emigração para os E. U. da América, onde é proibida a venda de aguardente ou de outra qualquer bebida alcoólica.

E, entretanto, diz-se que os indígenas de Cabo Verde são bêbados e indolentes; e isto repete-se na imprensa, em relatórios, em trabalhos de fomento, e até em livros, e muitas vezes por brancos que, na ocasião, estão debaixo de uma terrível influência alcoólica!... (Ibidem).

Mestre Eugénio via na educação, na criação de escolas uma saída para que essa concepção equivocada pudesse ser, de uma vez por todas, erradicada:

Procurai, senhores doutores, pôr termo ao abuso do álcool, educando e instruindo todas as camadas da população portuguesa, sem olhar à cor de cada um, nem investigar de onde são indígenas.

Porque é que haveis de atribuir ao preto, e só ao preto, um vício que está generalizado em todo o mundo e em todas as camadas sociais?

Não conheceis, como nós, terras, só de brancos, onde a assiduidade nas casas de bebidas e a conseqüente embriaguez são o chic?

Ora é com exemplos e com o ensino que o preto aprende a não ser desleixado e bêbado, mas não com o exemplo dos brancos da tal terra que conhecemos, nem com falta de escolas; pelo contrário: é criando estas e confiando a sua regência a professores brancos ou pretos (a cor não importa) com competência profissional e moral, e tornando obrigatória a sua freqüência (Ibidem, grifos nossos).

O artigo era assim arrematado, em favor da população cabo-verdiana:

O indígena de Cabo Verde é activo e trabalhador. Que o digam todos esses terrenos agricultados na província, que eles trabalham conforme lhes têm ensinado as escolas que conhecem.

Que o digam as fábricas americanas, onde eles vão mostrar actividade que aqui não podemos mostrar. Que o diga também essa imensa sepultura líquida que se estende em volta desta bola que habitamos (Ibidem, p. 107). 
A temática explorada no artigo de jornal, acrescida da sensibilidade do poeta, será reiterada num soneto (publicado com pseudônimo), do qual extraímos trechos ${ }^{11}$ :

À mesa, um dia, estavam dois doutores
sobre matérias graves discorrendo:
$[\ldots]$
Tratava, um, de provar que os bebedores
crioulos, (brancos nunca!) iam perdendo
a mioleira, em virtude dos calores
que a pinga neles vai desenvolvendo...
[...] se toda essa manada de crioulos
desprovida estivesse de miolos
quem nos fabricaria, hoje, essa cana
que divina parece mais que humana?

Dic (TPOLP, p. 43)

$\mathrm{O}$ argumento defendido pelo interlocutor do poema, na última estrofe, encontra eco no texto jornalístico, que interroga:

Porque é que haveis de atribuir ao preto, e só ao preto, um vício que está generalizado em todo o mundo e em todas as camadas sociais?" Não conheceis, como nós, terras, só de brancos, onde a assiduidade nas casas de bebidas e a conseqüente embriaguez são o chic? (TPJ, p. 106).

Um dos intelectuais mais destacados de sua época, Eugénio Tavares, cedo, mostra-se um nativista apaixonado. Por meio da imprensa, publicará textos significativos sobre o tema, rebatendo os adversários que viam no movimento uma ameaça ao patriotismo e, consequentemente, um desafio à soberania portuguesa.

No artigo "O Nativismo Através da Alma de Mistral”, publicado em 1914, no n. 176 d'A Voz de Cabo Verde, Eugénio Tavares define o que é ser nativista:

um direito de amar, entre todas as Pátrias, Portugal, nossa pátria; de bem querer entre todas as terras portuguesas, Cabo Verde, nossa terra; de adorar, entre todas as ilhas cabo-verdianas, a ilha em que nascemos, em que amamos, em que fomos felizes. E se isto é crime, crimes são, de certeza, todos os mais levantados e nobres sentimentos humanos.

Crime, o nativismo? Crime amarmos mais o que é nosso que o que é alheio? Será crime esse dulcíssimo sentimento de amor à terra em que nascemos? (Ibidem, pp. 156-157)

\footnotetext{
${ }^{11} \mathrm{O}$ soneto será analisado adiante, no capítulo relativo à poesia de língua portuguesa.
} 
Malgrado todos os obstáculos, para Eugénio a opção será sempre Cabo Verde:

E tanto que antes queremos ser portugueses aqui, com frio e fome, nesta terra de estiagens, que estrangeiros nas terras mais opulentas e felizes. Será isto um erro? Desde quando é erro a dignidade humana?

E tanto que preferimos para viver e para morrer, a aridez e a miséria de Cabo Verde, ao bucolismo do Minho, por exemplo, ou às riquezas das nossas Áfricas. Isto será um crime? Desde quando são crimes a dedicação e o regionalismo, bases do patriotismo? [...]

Porque, nesses países, seríamos estrangeiros, e no nosso, filhos. Honra é amarmos mais a estas ilhas esquecidas de Deus e dos homens que a outras mais ricas e fecundas terras sobre as quais tremula a bandeira da nossa nação. Porque lá nós seríamos forasteiros e aqui estamos em nossas casas (Ibidem, p. 157).

O intelectual entendia que, para haver patriotismo, antes era preciso sedimentar uma estrutura que levasse a tal sentimento pelas vias do nativismo:

Cada povo pugna pela sua região dentro da Pátria; cada cidadão trabalha para sua família, dentro da região. Isto é a base do patriotismo; e da estrutura social. Sem lares não há nações; como sem amor não há família. Forma-se uma nação como se forma uma floresta: cada árvore raíza-se na terra em que nasceu. Depois, unidos, é que todos os carvalhos costumam oferecer uma resistência invencível aos próprios ciclones. [...]

É, sim; quanto mais amamos as nossas regiões, mais poderemos adorar a nossa Pátria.

Não se chega, inclusivamente, a esta adoração, sem passar por aquele amor. E, se nativismo é amor à terra, é um factor do patriotismo; e não vemos maneira de crer na sinceridade de um patriota que não é nativista. Admitamos pois que o nativismo seja a origem enternecida e santa do patriotismo, e não erraremos (Ibidem, p. 158).

A partir da publicação de artigos dessa natureza, José António Nobre Marques

Guimarães ressalta que:

Agudizava-se a consciência política daquele que viria a ocupar um lugar de relevo no combate nativista após a implantação da República, nas páginas d' A Voz de Cabo Verde. A partir de 1911, no contexto da defesa intransigente do ideário libertador republicano que viria a mobilizar a elite intelectual nativista de Cabo Verde, Eugénio Tavares empenhar-se-ia na defesa dos direitos do seu povo, dando continuidade à luta iniciada n' A Revista de Cabo Verde e n' A Alvorada, denunciando, sistematicamente, as contradições cada vez mais gritantes entre os princípios daquele ideário e a prática política das administrações republicanas da colónia após a demissão e o regresso a Portugal, sob prisão, do seu primeiro governador 
republicano, Marinha de Campos, cuja política em defesa dos caboverdianos the granjeara a acusação de nativismo ${ }^{12}$.

No n. 205 de $A$ Voz de Cabo Verde, Eugénio Tavares, discorrendo sobre as eleições para deputado, conclama o povo cabo-verdiano para que vote em candidatos comprometidos com o desenvolvimento do arquipélago:

Somos portugueses nascidos e criados em Cabo Verde. Amamos muito a nossa Pátria, e não menos a nossa província. Temos a honra de ser nativistas no justo e próprio significado da palavra. Nativismo, aqui, é duas coisas: $1 .^{\mathrm{a}}$ - Legítimo e nobre sentimento de amor ao lar, que constitui o mais forte e o mais levantado plinto do patriotismo. 2 a $^{\mathrm{a}}$ - Um vocábulo ao qual a má fé corrosiva tem, debalde, tentado ajustar significados extravagantes (TPJ, p. 195).

Vale lembrar que, aos olhos das autoridades políticas portuguesas, o movimento nativista era suspeito de ser antiportuguês. Eugénio Tavares, com a publicação desses textos, buscava justamente esclarecer e fazer compreender justamente o contrário: o nativismo constituiria a base para a construção de uma nação portuguesa forte em todos os aspectos.

A este respeito, Fátima Monteiro informa que:

A continuação, ao longo do período liberal e da I República, de práticas discriminatórias pelo governo de Lisboa, como por exemplo a preferência dada a metropolitanos no preenchimento de quadros administrativos na colónia, acabou por promover e radicalizar o nativismo cabo-verdiano. Em determinada altura chegou mesmo a defender-se, abertamente, a independência ${ }^{13}$.

Em 1915, Eugénio levantava-se contra o projeto da Carta Orgânica que pretendia, entre outras coisas, implantar o estatuto do indigenato em Cabo Verde. Publicou, na ocasião, um longo artigo, por partes, nos números 187, 188, 189, 190, 192 de $A$ Voz de Cabo Verde, no qual procurava alertar as autoridades e o povo sobre as incongruências daquele documento.

Definindo o termo "indígena” como impróprio, esclarecia Eugénio:

Indígena, é: gerado ali, nascido no país. Não se entende, porém, assim, o termo, no uso que dele a lei tenta fazer. [...] E tomando-se

\footnotetext{
$12 \mathrm{http}: / /$ www.eugeniotavares.org/docs/pt/noticias/nativismo_eugenio tavares.html. Acesso em maio de 2010.

13 http://www.ieei.pt/files/Cabo_Verde_encruzilhada_atlantica_Fatima_Monteiro.pdf. p. 5, s/d. Acesso em maio de 2010.
} 
estas palavras - indígena - nessa acepção, nós teríamos de admitir a hipótese de, amanhã, poder, um filho de Sua Ex. ${ }^{a}$ o sr. Governador, nascido em Cabo Verde e, logo, indígena, ser condenado, pelo sr. Administrador do Concelho, por ter vindo mais alegre de uma festa, a trinta dias de trabalhos públicos, segundo a letra do art. ${ }^{\circ} 148 .^{\circ}, \mathrm{n}^{\circ} 1 .^{\circ}$, alínea a) da Carta Orgânica!

Em Cabo Verde não há semelhante diferença de nível nos direitos que a lei reconhece aos cidadãos. Não há. Não deve haver. [...]

Se a intenção foi referir-se a impostos de trabalho, etc., ainda o termo indígena nos parece impróprio, pois que tais impostos recaem sobre todos os habitantes sem distinção de classes nem de localidades de nascimento (TPJ, p. 170).

Acrescentava à discussão do termo o argumento que qualificava a "personalidade" cabo-verdiana fundada na dignidade:

No dia em que uma lei estabelecesse tal diferença entre os contribuintes cabo-verdianos; no dia em que se decretassem impostos que recaíssem exclusivamente sobre os naturais da província, estabelecendo uma selecção, entre os seus habitantes, por localidades de nascimento; no dia em que, os cabo-verdianos fossem considerados indígenas; e, por oposição, e com propriedade, os metropolitanos se reduzissem a exóticos; nesse dia os cabo-verdianos com dignidade abandonariam de vez as suas ilhas, indo fixar-se em qualquer país onde nada lhes lembrasse a desgraça e a vergonha de terem sido párias na sua própria terra (Ibidem).

Mais adiante, Eugénio Tavares fazia um apelo para que o projeto de Carta Orgânica elaborado por autoridades metropolitanas não fosse aceito em Cabo Verde, uma vez que considerava que

esse diploma, dizíamos, não satisfaz ao desenvolvimento de Cabo Verde. Porque Cabo Verde não é Timor. Porque em Cabo Verde não há tribos selvagens. Porque o cabo-verdiano é um elemento civilizado da nacionalidade portuguesa (Ibidem, p. 175).

$\mathrm{Na}$ defesa intransigente das qualidades do homem de Cabo Verde, voltava a afirmar que

há 50 anos já se pensava na conveniência de considerar estas ilhas como adjacentes, nelas implantando o regime de assimilação que vigora nos arquipélagos madeirenses e açoriano.

O povo de Cabo Verde nega aquela classificação desacertada (que a intenção e as circunstâncias tornam provocadora, humilhante e insultuosa) que se lhe quer dar num diploma legal.

O povo de Cabo Verde unir-se-á para, sob a lei, repelir afrontas à sua dignidade cívica de cidadãos livres da República Portuguesa. (Ibidem, p. 185). 
Segundo nos esclarece José António Nobre Marques Guimarães:

Apesar do endurecimento crescente da política colonial republicana, Cabo Verde acabaria por não ser abrangido por aquele regime, ao contrário do que viria a acontecer em Angola, em Moçambique e na Guiné, onde a sua implantação fez com que a esmagadora maioria dos seus habitantes africanos viesse a ser privada da cidadania e reduzida à condição indígena desprovida de direitos ${ }^{14}$.

Eugénio Tavares usou o poder de sua escrita jornalística, também, para rejeitar o racismo que imperava na época. Para ele, Cabo Verde só alcançaria o desenvolvimento se houvesse igualdade entre brancos e negros. A distinção de raças significava atraso, miséria, exploração do homem pelo homem.

Um bom exemplo de sua recusa a esse preconceito pode ser extraído do texto "Brava - Trechos de uma Monografia", publicado no Boletim da Agência Geral das Colónias, Ano V, n. ${ }^{\circ} 45$, março de 1929, no qual Tavares disserta sobre a formação do homem da Brava:

A gente bravense é branca ou mista, produto admirável de cruzamentos dos primeiros colonos oriundos de Portugal, com mestiços vindos principalmente da vizinha ilha do Fogo.

[...] Eis a razão por que em 1680, a gente livre do Fogo, que pudera fugir às assolações da estiagem, encontraria a ilha já habitada. [...] alguns casais do Fogo se refugiaram na Brava, indubitável é que já encontraram a ilha habitada por famílias brancas.

Todo este arrazoado para trazer à história a confluência de um veio de verdade; e não porque essa sonhada origem guineana nos importe depressão, pois que a dignidade humana não está na cor da epiderme. Antes, honra insigne seria descender de escravos e ter subido a senhores... já que ninguém ignora que, na ilha Brava, cada homem é um senhor independente e livre em toda a acção social (TPJ, pp. 224-227, grifos nossos).

Ao longo de sua carreira, Nhô Eugénio colaborou em vários jornais metropolitanos cujos programas estavam voltados para a defesa da causa africana em terras portuguesas, como: O Negro, A Mocidade Africana, África, Correio de África, $O$ Protesto Indígena, Tribuna de África, A Voz de África.

O posicionamento corajoso do jornalista bravense fica evidenciado em inúmeros dos seus textos em prosa, que constituem retratos da sociedade cabo-verdiana dos finais do século XIX e primeiras décadas do século XX, expostos com um realismo

\footnotetext{
${ }^{14}$ http://www.eugeniotavares.org/docs/pt/noticias/nativismo_eugenio_tavares.html. Acesso em maio de 2010 .
} 
interventivo que impressiona o leitor, pela preocupação demonstrada em denunciar os desmandos do colonizador e bradar para que medidas eficazes fossem tomadas para solucionar ou, pelo menos, minorar os problemas sociais presentes em todas as ilhas.

Outro ato de coragem evidenciado nos textos jornalísticos foi a defesa da língua crioula (na época de Eugénio denominada dialeto e atualmente, língua caboverdiana), na senda de Pedro Cardoso. Eugénio Tavares foi um grande cultor do falar dos naturais de Cabo Verde, basta-nos lembrar as suas Mornas - cantigas crioulas, conjunto de vinte e cinco (25) peças líricas produzidas em crioulo bravense. O seu amor pela forma de expressão de todos os cabo-verdianos o levou a publicar, em janeiro de 1924, no n. ${ }^{\circ} 11$ do jornal $O$ Manduco, do qual ele era editor, um texto (editorial) revelador de seu pensamento a respeito de como o sistema colonial tratava a questão linguística. O título "Língua de Pretos”, por si só já é bastante revelador. Neste artigo, Eugénio definia o crioulo como expressão híbrida, ressaltando sua originalidade e defendendo a necessidade de seu estudo linguístico:

O dialecto cabo-verdiano constitui documento glotológico de uma das mais interessantes transformações da língua portuguesa.

Mestiçada pelo contacto de duas raças diferentes, num consórcio de séculos; ressentindo-se da influência exercida, em longas gerações de colonos, por multidões de escravos; em breve a língua dos senhores tomou os vícios prosódicos dos escravos, conservando, ao lado de arcaísmos lusitanos pitorescamente, fonalidades bárbaras de muitos vocábulos sonoros, e de poucas expressões interjectivas.

[...] estou em crer que todo o facto que signifique actividade trasnformadora, tem sempre, para o estudioso, algum valor.

As raças mistas, expressões novas, oferecem campos de estudo: à antropologia, na novidade do seu ser físico; à glotologia, na originalidade do seu modo de exprimir. Desde que não seja possível negar que o cabo-verdiano pensa; e que dispõe de palavras para dizer o seu pensamento; e que usa de regras para a arrumação dessas palavras; e que, finalmente, tais palavras e regras constituem o resultado de uma colaboração de elementos associados na colonização, - fica admitida a utilidade do estudo dessas palavras e regras, como elementos para o estudo da colonização. E, se me não ilude minha incompetência, esse estudo é que constitui a gramática (TPJ, pp. 218-219).

E prosseguia, contra o argumento de que o crioulo constitua "língua de pretos", como era pejorativamente denominado por teorias colonialistas:

Os dialectos coloniais, derivados da língua pátria, documentam a história da nossa colonização, e provam que os antigos portugueses deram às colónias longínquas não só o seu sangue - o que pegou as 
terras e o que nos corre nas veias, - não só sua cultura e seu modo de ser social e moral, como sua própria língua. [...]

Língua, quem a ouve, não a julgará entroncada nos Lusíadas... Entretanto, acredita-se que não é a língua de pretos dos despresativos dizeres de gentes não menos desapercebidos de escrúpulos, que desfavorecidas de inteligência [...]

E a chamá-lo língua de pretos, melhor seria dizê-lo língua de brancos mal ensinada a pretos, - a pretos que criaram os filhos desses brancos, que os trouxeram ao colo, e que lhes acalentaram os sonos da infância com as tristíssimas melopéias da saudade dos lares distantes e do sofrimento da escravidão (Ibidem).

Ao concluir o editorial, Eugénio afirmava que: "[...] o dialecto cabo-verdiano pode falar-se e grafar-se. Por muitos motivos, e, principalmente, porque constitui a documentação de uma transformação, digo, de uma das transformações felizes da língua portuguesa entre os povos coloniais" (TPJ, pp. 218-219).

Em se tratando de uma época em que o sistema colonial português tudo fazia para anular quaisquer manifestações identitárias nas colônias, o texto de Eugénio Tavares é altamente transgressor e demonstra toda a coragem e isenção do autor, que não se deixava intimidar nem dobrar pela força dominante.

No prefácio à recolha Eugénio Tavares: viagens, tormentas, cartas e postais, Manuela Ernestina Monteiro afirma:

Ao nosso código lingüístico Eugénio conferiu beleza e dignidade literária, numa época em que "espíritos letrados verberavam essa língua espúria e sem gramática". [...] o purismo que o caracterizou não impediu que palavras híbridas deslizassem a meio de construções em português vernáculo e que adoptasse, frequentemente, um pseudônimo, que exala o perfume do crioulo da ilha Brava, "Djôn de Mamai" (Prefácio a TVTCP, p. 9).

Defender a identidade e a língua cabo-verdianas foram princípios que demonstraram o profundo apreço que o bravense alimentava pelo seu povo, sua terra, sua cultura, enfim, por tudo que fosse, na sua concepção, cabo-verdiano.

Em entrevista concedida a Michel Laban, Gabriel Mariano, ao enfatizar a opção de alguns poetas pelo uso da língua cabo-verdiana, apontava que:

Escrevendo em crioulo dão-se duas coisas. Primeiro aspecto: uma identificação através da língua crioula, uma identificação com o seu próprio ambiente - a própria ilha, com a própria região, etc. a língua materna reconduz-nos à mãe e há então esse fenómeno - em crioulo uma identificação do poeta com a sua própria terra. O outro aspecto é que os poetas que escreveram em crioulo foram grandes poetas, 
originais, criativos, em crioulo (MARIANO, entrevista a LABAN, 1992, pp. 325-326).

Há quem afirme que a qualidade de sua produção poética em língua caboverdiana acabou por relegar a um plano de subalternidade sua produção em prosa. Todavia, Arnaldo França contrapõe: "não creio que no período em referência se encontre, entre nós, prosador que possa ombrear com Eugénio Tavares” (1993).

Manuela Ernestina Monteiro afirma que:

Dirigindo-se, simultaneamente, a um destinatário determinado e ao público mais vasto, as cartas de Eugénio Tavares traçam o retrato moral, social e político de Cabo Verde. Ricas pelo conteúdo, importantes para a história da época, abarcam todos os assuntos que apaixonaram esse incansável lutador (MONTEIRO, prefácio a TVTCP, p. 11).

Corsino Fortes reforça as palavras de Manuela Monteiro, acrescentando que é nas cartas "onde se ergue o carácter e a personalidade inquebrantável do lutador que Eugénio foi, consciente da grande arma que é a escrita" ${ }^{15}$. Fortes prossegue, afirmando que: "tanto a epístola como o panfleto, ambos se organizam com a elegância bíblica de um sermão e têm a força inabalável de funda de David quando se impõe a defesa dos superiores interesses dos desamparados e dos perseguidos pelo abuso dos poderosos ou pela incúria dos governantes" (Ibidem).

Com efeito, é possível observar em suas cartas um Eugénio Tavares na dimensão de pensador e de formador de opinião. Em sua epistolografia, as suas preocupações de cunho eminentemente político, anteriormente expressas nos textos jornalísticos, serão expostas com maior ênfase. Percebe-se que, em suas cartas, Eugénio, com certa frequiência, empregou um estilo panfletário.

Manuela Ernestina Monteiro destaca:

As reflexões e posições por ele assumidas revelam um homem profundamente preocupado com a sua terra e com os seus concidadãos, um crítico mordaz e impiedoso da administração da colónia, inconformado com a miséria dos seus semelhantes e com a insensibilidade do poder político (TVTCP, p. 13).

O excerto a seguir, retirado de "Cartas para a América" e endereçado ao "amigo Inocêncio Cândido Simplício", corrobora a constatação da pesquisadora:

\footnotetext{
${ }^{15}$ Disponível em: http://www.eugeniotavares.org/docs/pt/obra/cartas.html. Acesso em maio de 2010.
} 
Nos anos de fome, a ilha, na décima parte da sua população exposta à miséria, sofria cruelmente. De uma vez em que o povo pediu socorros, da Secretaria veio uma resposta que estalou como uma bofetada nas faces da ilha: o governo nada podia fazer; que se apegassem às juntas de paróquia (TVTCP, p. 162).

Desgostoso com a insensibilidade das autoridades responsáveis por minorar tal situação e num ato de revolta, Eugénio Tavares cria uma comissão municipal republicana (sendo ele mesmo o seu Presidente) que

resolveu constituir bandos precatórios, pedir esmolas, para socorrer o povo. E um belo dia, reunida a comissão distribuidora de esmolas na casa de residência do tesoureiro Valentim Campos, enquanto que os marinheiros da canhoneira que viera trazer o governador de visita à ilha, despejavam as algibeiras no cofre das esmolas; e enquanto o governador e sua comitiva se banqueteavam em casa do administrador do concelho, os membros da comissão republicana da ilha Brava, de fita verde e encarnada na botoeira, distribuíam, em nome do ideal republicano, à luz dos princípios que deviam, anos depois, sacudir a Nação Portuguesa e acordá-la da sua letargia de séculos, distribuíam esmolas aos famintos num gesto de desafio, não desmentido não controvertido, a esse governo que tinha negado socorros a um povo faminto (Ibidem, "Cartas da América", p. 162).

Eugénio sempre foi muito perspicaz no direcionamento de suas críticas. Selecionava cuidadosamente os adjetivos de conotação negativa e vocábulos de inclinação satírica para acertar o alvo com eficiência e mordacidade. Nada the passava incólume. O uso da ironia foi uma arma poderosa para denunciar aquilo que não lhe parecia justo como, por exemplo, a condução da educação dos cabo-verdianos por parte de pais, educadores e autoridades responsáveis, como podemos observar neste relato (crônica) intitulado "Em viagem”, Capítulo I:

Há, no nosso meio - que é o extremo da miséria e da ignorância pessoas, aliás muito respeitáveis, que, tendo a rara felicidade de ser pais de filhos aplicados, [...] submetem-nos a um regime escolar dosimétrico [...]. Alguns desses pais, muito a dentro do seu papel de educadores práticos, costumam, entre dois arrotos, regougar: - Nada de muita doutorice. Actualmente as sabedorias estão dando em droga que é uma consolação. Basta que os rapazes saibam escrever duas regras para dar parte da saúde. Cá estou eu, por exemplo, que mal risco o meu nome; e que, graças a Deus, é o que se vê e o que se sabe (TVTCP, p. 34).

Eugénio compara o desenvolvimento lento no campo da instrução formal com o travamento do progresso de S. Vicente e, por extensão, das outras ilhas: 
Citei isso para poder dizer que, entre tais filhos do bambúrrio e o nosso atiladíssimo governo provincial [...] encontro certos pontos de semelhança: afigura-se-me - e, evidentemente que não devo nem posso afirmar que não esteja em erro - que o governo paternal e conscienciosamente orientado da nossa província [...] vai sofreando $S$. Vicente, ministrando-lhe elementos primários de desenvolvimento em uma dosagem infinitesimal, inventando pretextos para iludir o cumprimento de certos e indeclináveis deveres, forjando regulamentos que restrinjam a navegação, que enfreiam o comércio e mantenham a indústria no seu próspero estado de hipótese; indo, cautelosamente, pelo seguro (como se exprime piscando o olho esperto) de mão no travão para ir devagar... que é como se vai ao longe (Ibidem).

A incapacidade do governo, neste mesmo texto, leva Eugénio a fazer referência a uma única obra construída pela iniciativa estatal num período de vinte anos, nível de realização inaceitável para uma ilha que, nesta época, gozava de excelentes perspectivas de desenvolvimento em razão das ótimas localização e condições do Porto Grande:

Deixei S. Vicente em 1887; volto a S. Vicente em 1907 estava já S. Vicente numa latitude de abordar pronto e seguro progresso material, devido devo dizê-lo, pouco menos que exclusivamente aos esforços da iniciativa particular, a qual, em verdade, no nosso meio, labora sempre a despeito da iniciativa oficial.

Vinte anos transcorridos, que progresso noto em S. Vicente?

Ponho de parte aqueles que são devidos, ainda e sempre, não aos elásticos capítulos orçamentais, e dou, por atacado, o que o governo tem feito: o edifício do Correio. E, ainda assim incompleto pois lhe falta a competente redoma de vidro, uma espécie de estufa que possa permitir aos empregados respirar uma atmosfera menos mal cheirosa que os aromas de uma próxima ponte de despejos, e menos asfixiante que a nuvem negra de pó que se levanta dos próximos quintalões carvoeiros (Ibidem, pp. 33-34).

Problemas de infraestrutura em Cabo Verde, à época da escrita de sua obra, também foram tratados por Eugénio Tavares em forma de poesia. A precariedade da iluminação pública e do saneamento, por exemplo, levaram-no a produzir sonetos com o pseudônimo Orion, e aqui destacamos um excerto ${ }^{16}$ :

\section{Luz e Flores}

A nova comissão municipal, promete-nos mais luz e uns jardins, com um quiosque envolto por jardins, na praça da cidade, a principal.

\footnotetext{
${ }^{16}$ Mais tarde voltaremos a este tópico, quando examinarmos a produção poética eugeniana em língua portuguesa.
} 
Mas para que tal melhoramento, os benefícios possam resultar,

é preciso fazer encanamento,

de matérias um tanto mal cheirosas

$[\ldots]$

Orion (TPOLP, p. 39).

Mesmo apontando uma série de abandonos, desleixos e dificuldades em todo o arquipélago, Nhô Eugénio segue descrevendo a ilha Brava, seu torrão natal, do qual se apartou por longo tempo, como cenário perfeito e, em extensão, Cabo Verde como a terra amada. Examinemos um fragmento da carta a Inocêncio Cândido Simplício:

Logo de manhã [...] a nossa querida ilha, ainda mal desperta, como que estremunhada do repouso nocturno, [...] com o seu turbante de névoas macias, erguia-se como uma adorável cabeça de crioula toucada com o alvíssimo lenço de noite.

- Ó pequenina estância estremecida e nunca olvidada! Ó minha terra! Árvores! montes! rochas e muros revestidos de líquen! velhas roseiras debruçadas sobre as azinhagas! e tu, antigo cemitério, terra sagrada, onde as raízes se sustentam de sangue, e sobre cujas ervas não têm caído mais orvalhos do céu que lágrimas de olhos viúvos de afeições! e tu terra santa, onde o surdo sublime, Guilherme Dantas, quando chegou homem, tendo partido criança, veio colocar os seus lábios e chamar por sua mãe morta! e tu, em cujo seio dormem as nossas mães! eu vos saúdo! O meu espírito beija-vos! Quanto vos adoro! E quanto me fere, longe de vós, a saudade! (TVTCP, "Cartas para a América", p. 179).

Acossado pela saudade - também referida no texto de estilo híbrido, líricoepistolar, intitulado "Crónicas Tristes" e dedicado à sua mãe adotiva ("De vez em quando, sobre essa terra gelada desabrocham saudades que dão ilusões de vida à minha agonia”, Ibidem, p. 87) -, Mestre Eugénio, instalado na América, exalta as roseiras antigas de sua ilha de origem, os vultos da literatura bravense, como Guilherme Dantas, e a perspectiva de volta ao lar:

Como é doce o regresso à terra natal!

$\mathrm{O}$ ar fresco, fino, perfumado: as roseiras e as madressilvas, em Maio desentranham-se em cachos; e as amoreiras, numa languidez, deixam pender as largas folhas como feltros verdes (Ibidem, p. 179).

O texto "Tormentas", endereçado ao Sr. Dr. Mário Ferro, pode ser tomado como metáfora do estado de espírito do nativista obrigado a deixar Cabo Verde, quando de sua fuga para os Estados Unidos da América, em decorrência da acusação de 
apropriação de dinheiro público. Os problemas pessoais enfrentados pelo autor se assemelham a uma tempestade em alto mar, expressa por imagens hiperbólicas que impressionam o leitor:

Oh! o navio em plena tormenta!

O mar cospe-lhe insultos sangui-escumosos; arrebata-lhe do convés as embarcações peiadas; quebra-lhe as asas com que voa; arromba-lhe as tábuas com que se aguenta; rouba-lhe o leme com que se arruma; desmastreia-o; destronca-o; desarvora-o! E, finalmente, ou o mete no fundo com toda a tripulação, com toda a carga, com todas as esperanças e todos os sonhos; ou, remanseado pouco a pouco, o abandona agonizante, reduzido a um frangalho, a uma prancha vogando, à conta da corrente, sobre o adormecido cansado do mar.

O espectáculo do homem perseguido pelo ódio, não é menos grandioso que esse do navio que os turbilhões do ciclone arrebatam. Basta que o piloto seja atrevido, e tente atravessar em plena invernia a "Storm region", para que o assaltem as fúrias da borrasca! Basta que o homem seja intransigente, e force para se manter, em crise de decomposição social, na recta de um ideal elevado, para que o rodeiem as gorgonas que a inveja envenena e solta! (Ibidem, p. 83).

Diante do sofrimento resultante da necessidade de afastar-se por tanto tempo de sua terra de origem, Eugénio, em prosa eivada de poesia, coloca em destaque a sua Ilha das Flores (principalmente os "cardeais"), ressaltando para conhecimento do amigo Simplício as belezas naturais, os aromas, as cores, a tranquilidade da vida cotidiana:

Em Abril, quando pelo côncavo deleitoso se toucam as laranjeiras com grinaldas de noivas; e pelos caminhos bordados de rubros cardeais, de baunilhas odoríferas [...]; pelo mistério das espessuras soa a surdina suave dos prelúdios amorosos das toutinegras; [...] a natureza como que acorda espreguiçando-se e sorrindo castamente pelas bocas perfumadas das flores (Ibidem, p. 193).

Nas palavras de Manuela Monteiro, Eugénio Tavares, em sua prosa, transforma-se em artista plástico, uma vez que:

A sua pena, qual pincel em hábeis dedos, surpreende a beleza da natureza e fixa-a em páginas que se aproximam a verdadeiras telas. $\mathrm{O}$ estilo que adopta para descrever a paisagem bravense resvala para a prosa poética, tal é a beleza das construções, a musicalidade alcançada, a poesia que se desprende de cada vocábulo.

Tudo a traduzir o sentimento que o liga à ilha de nascimento. $\mathrm{O}$ elogio superlativo da paisagem da ilha, muito frequiente na pena de Eugénio, contém uma nota de nacionalismo, um dos traços mais marcantes da estética romântica (MONTEIRO, prefácio a TVTCP, pp. 8-9). 
A descrição hiperbólica da ilha que fora obrigado a abandonar alça a prosa cabo-verdiana a momentos de raro lirismo:

Tanta beleza! tantas flores!tanta exuberância! [...]

Da última vez tinha eu deixado o meu vale toucado de flores, a chuva fina perlando as folhagens novas, as rosas inclinadas ao peso das gotas brilhantes, os rochedos fronteiros húmidos e glaucos escorrendo água pelas barbas das urzes e das criptogâmicas, semelhantes a deuses marinhos levantados das águas mitológicas do Arquipélago. Estava a ilha vestida de verde como quando a primavera se noiva, nos últimos dias, para a festa panteísta do fruto, quando as últimas pétalas voam ao vento. Desnastravam-se as rosas e as madressilvas sobre os muros vetustos semelhando grinaldas toucando bustos de faunos (TVTCP, pp. 69-73).

O apego à ilha de nascimento pode ser uma explicação para que Eugénio tenha usado o termo "pátria" ora em referência a Portugal, ora em referência a Cabo Verde: "sigo aos pátrios montes, a aspirar o perfume das rosas, a beber o orvalho das manhãs douradas, e a ver se os gorjeios das toutinegras e se os rumores familiares do meu vale, acordam a poesia anestesiada e semimorta no fundo do meu cérebro" (Ibidem, p. 77).

Em entrevista a Michel Laban, Manuel Ferreira esclarece:

Às vezes, a pátria é onde tiveram a sua vivência da infância, ou da meninência, ou coisa parecida... Outras vezes, a pátria é Portugal - "a pátria", "os nossos avós", os nossos pais", "os nossos irmãos", a nossa terra"... [...] Como é que se explica, ou como é que se pode explicar, ou é possível explicar esta ambiguidade de duas pátrias - e ditas com a mesma veemência?

Para mim, tenho esta explicação - boa ou má: primeiro, são homens que estão sob o peso de uma ideologia trazida pelo colonizador através de literatura, da arte, da crítica, etc., etc., e que aprenderam nas escolas; e, depois, é o discurso oficial; depois, são também homens que são o produto de uma longa mestiçagem, de uma profunda aculturação. Por consequência, do ponto de vista cultural, estavam muito próximos da cultura portuguesa. [...] Por outro lado, eles são autenticamente cabo-verdianos: são bilíngues, são homens que comem cachupa, comem cuscuz, amam a morna, naquele tempo também a mazurca, que ainda havia, etc., etc., são homens que amam a sua terra, a geografia, a corografia, a paisagem, o mar, o crioulo - então eles são cabo-verdianos e, assim, a sua pátria é também Cabo Verde. A Pátria cabo-verdiana é a máter, é a mãe para eles, é a origem, a maternidade, é onde eles nasceram, onde eles beberam, é o leite - estão a ser amamentados permanentemente pela mátria. A outra pátria é o pai, a pátria portuguesa é o pai. E então eles são presos de uma apetência dúplice. Mas é natural que o complexo, edipiano, com o tempo vá funcionando (FERREIRA in LABAN, 1992, pp. 111-112). 
Nesse sentido, o apego, a fidelidade, o empenho devotado na defesa das ilhas e a coerência dos seus ideais com a sua vivência, credenciam Eugénio Tavares como um dos precursores da cabo-verdianidade.

O poeta José Lopes, em homenagem póstuma (1931,) assim definiu a relação que Eugénio Tavares tinha com a ilha Brava e com a sua "téra sabe", Cabo Verde:

Há nomes que são uns símbolos.

Tal o de Eugénio Tavares. [...]

Sintetiza e define a sua terra. [...]

O grande Poeta vive hoje no seu "splendid isolement" da risonha Brava, onde nasceu, a Brava que o idolatra e que Ele tanto ama; porque Ele é a Brava e a Brava é Ele; e a Brava, porque é Ele, porque o encerra no relicário das suas formosas filhas e das suas flores, incomparáveis de matiz e fragrância, resume em si Cabo Verde (LOPES, 1999, pp. 294-296, grifos nossos).

Além da bandeira da cabo-verdianidade, Eugénio Tavares, desde muito cedo, defendeu os valores republicanos e democráticos, a liberdade de expressão e os direitos da imprensa. Grande polemista, possuía dotes de escrita dignos de serem temidos por seus mais fortes adversários. Suas convicções políticas o levaram a ser perseguido como alvo das mais rasteiras estratégias. No entanto, jamais se deixou subjugar. Os ataques que sofria se tornavam alimento e o deixavam mais forte para reagir com sua poderosa pena. Sobre os reveses por que passava, considerava-os como

os únicos gostos da minha vida pública; porque me deixavam eles a gratíssima impressão de que a independência do meu carácter e a verdade das minhas convicções nada iam perdendo da sua pureza, nada sofriam, dentro da corrupção que é a atmosfera das regiões burocráticas (TVTCP, p. 101).

E prosseguia, detalhando-os:

Fui censurado por não querer abdicar da minha dignidade de homem; fui suspenso por me não ter deixado enxovalhar como funcionário, fui exonerado porque quis conservar a liberdade dos meus direitos civis, votando numas eleições contra o deputado proposto pelo governo (Ibidem, p. 101).

Para um dos seus interlocutores em Lisboa, o Dr. Henrique de Vilhena, político português cujo primeiro contato se dera durante uma viagem de navio, Eugénio vai 
descrever em minúcias a perseguição a que vinha sendo submetido. Em carta do dia 08 de novembro de 1913, relata:

Segue, neste paquete, meu concunhado Medina, pai do José. Ele procurará o sr. doutor Vilhena. Se o sr. doutor dispuser de tempo, ele lhe contará a perseguição tenaz e vergonhosa que cá se me está movendo.

Eu tive agora ocasião de ver uma pequena esperança de justiça na noite tenebrosa do meu futuro. Depois, de repente, o sr. governador exigiu de mim um passo desonroso e eu preferi tudo a prostituirme. Imagine: um funcionário judicial, integro probo, inteligente, foi transferido para São Tomé, por não ter querido saltar por sobre a lei para se prestar a favorecer as vinganças do sr. governador contra mim! (Ibidem, p. 206, grifos nossos).

Numa missiva datada de 28 de julho de 1914, sentindo que os "amigos" de política em Lisboa the haviam virado as costas, lamenta-se ao Dr. Vilhena, uma das únicas exceções a lhe dispensar atenção:

$\mathrm{Na}$ Brava, onde passei alguns dias, recebi uma carta de V. ${ }^{a}$ Ex. ${ }^{a} \mathrm{E}$ muito me alegrou ver que ainda se lembrava de mim.

[...] Imagine que antes da República contei amigos entre os caudilhos da Revolução. Hoje não sabem o meu nome! Porque eles subiram ao ácume e eu fiquei, não só na obscuridade, como no lodo para onde me tinha arrastado o próprio facto de eu ter sido republicano activo como eles! Publiquei artigos na Voz Pública e no Norte, do Porto; na Batalha e na Marselhesa, de Lisboa.

A paixão dos meus escritos fez-me notado. Esmagaram-me sob o peso de uma acusação monstruosa. Processaram-me. Roubaram os documentos do meu crédito. Quanto rompeu a República, eu olhei para os meus antigos correligionários e lhes disse, agonizante: Agora tirem isto de cima de mim. O nome de meu pai, que uso, é puro, quero conservá-lo puro.

Não me ouviram. [...]

Espírito sereno e justo, que é a verdadeira sabedoria, encontro-o na bondade [com que] V. ${ }^{\text {a }}$ Ex. ${ }^{\text {a }}$ me trata e me ouve (Ibidem, pp. 206-207).

$\mathrm{Na}$ carta de 09 de setembro de 1915, dispensa ao amigo lisboeta mais detalhes acerca da acusação que lhe imputaram e dos desgostos dela advindos:

Essa como que insolubilidade da questão que há mais de quinze anos me atém numa situação difícil, crucificado num processo evidentemente inquisitorial, de novo me obriga a dar algum trabalho ao meu amigo.

Como sabe, fui dado por alcançado em 18.000 escudos, na recebedoria da Brava, em 1899. A recebedoria da Brava tinha de rendimento menos de 1.500 escudos, anualmente; regulando, a despesa, pela mesana importância. Para exercer o cargo tinham-me 
exigido uma fiança de 1.500 escudos. Quantos anos seriam precisos para haver no cofre da Brava um saldo de 18.000 escudos? E durante esses anos, que fora de dúvida não transcorreram, como é que se não deu por tão grande alcance? E como é que, poucos meses antes de a ratoeira desse alcance me ter fechado o pescoço, um balanço rigoroso dado na recebedoria a meu cargo, com a assistência do próprio inspector de Fazenda, Dias de Oliveira, do escriturário Guilherme de Meneses e das autoridades locais, eu fui reconhecido como quite com a Fazenda Nacional? Que pensará um homem justo acerca de um alcance dado em semelhantes circunstâncias, e, principalmente, logo a seguir a umas eleições renhidas, nas quais, na ilha Brava, eu fizera com que o governo sofresse uma derrota? (Ibidem, pp. 207-208).

A causa maior para a acusação é desvendada:

O meu único crime foi ser republicano com todo o fervor de uma mocidade incendida no culto dos ideais mais avançados; e foi, mais, ter sido, então, correspondente de dois jornais republicanos de Lisboa e de outros dois do Porto.

Também concorreu, e muito, para esse meu alcance, a pública manifestação que eu fazia do meu republicanismo, acontecendo, até, num jantar oficial a que assistiam Leote do Rego, o dr. Goulart de Medeiros e mais oficiais, o escândalo de eu fazer a apologia da república, envolvendo a minha ardente profissão de fé republicana. Foram estas e outras manifestações que me prepararam o alcance que ainda hoje esmaga a minha iniciativa de trabalho e a tranquilidade da minha família (Ibidem, p. 208).

O agente da perseguição também é desmascarado por Eugénio:

Quando o sr. Biker veio governar a província, procurou recrutar-me. Havia então grave cisão entre os elementos preponderantes nestas ilhas. Considerei que me seria preferível sofrer, a tornar-me criado de Biker. Desaceitei as propostas dele, e me senti imediatamente atacado pela matilha dele.

$\mathrm{O}$ meu amigo sabe quanto tenho sofrido. Ultimamente contei que ia ser julgado; o dr. Delegado, porém, promoveu fossem examinados uns livros que deviam estar no Conselho Superior da Administração Financeira do Estado. Neste sentido segue agora uma deprecada. Esse livro (ou livros) tinha desaparecido porque constitui prova da ratoeira em que caí. É o livro-caixa, então modelo 11. Estava cheio de emendas, de rasuras, de irregularidades. Os modelos 11 são escriturados pelos escrivães de Fazenda.

Um velho juiz do Supremo Tribunal, dr. Pinto Osório, amigo de minha família e que me conheceu em criança, informara, em carta, a meu tio dr. Vera Cruz, que o meu processo constituía um tal acervo de irregularidades que nunca poderia ser julgado. Raiou a República, e, era vez de romper para mim urna manhã de justiça, vi anoitecerem todas as minhas esperanças! E entretanto o meu único crime era ter sido republicano (Ibidem, p. 209). 
Os motivos de seu desligamento do jornal A Voz de Cabo Verde ficam evidentes ao lermos a carta envida em 20 de fevereiro de 1916 (ou 1917?):

Ultimamente, como deve ter lido, eu e meu cunhado Medina desligámo-nos da redacção d'A $V o z$ por discordância sobre a orientação do jornal.

Como sabe é A Voz de Cabo Verde propriedade do sr. Abílio Macedo, negociante desta cidade. O Governador Fontoura da Costa, compreendendo o mal que estava causando o açambarcamento do milho produzido na ilha, que alguns negociantes adquiriam por um preço mínimo e depositavam nos seus armazéns, ficando o mercado sem milho e o povo a braços com a fome, deu providências acertadas, contra as quais, feridos, se ergueram os açambarcadores. A Voz, então, nas mãos do seu proprietário, sr. Macedo, e estando eu e meu cunhado na Brava, arvorou-se em defensora do açambarcamento, atacando as medidas do governador Fontoura. Vim imediatamente à Praia; e quando vi que me era impossível enveredar, de novo, o jornal, no seu antigo trilho, desliguei-me de sua redacção, e, como eu, o sr. Carvalho, ad.or, e meu cunhado general Medina.

Senti desgosto vendo um jornal que até ali tinha defendido ideais levantados e generosos, descer, de repente, no mais raso mercantilismo, fazendo-se órgão do mais triste papel que o comércio ainda se distribuiu: o açambarcamento; a redução do povo à miséria. [...]

Estou desgostoso com o rumo que isto tem tomado. [...] Cabo Verde é uma terra infeliz.

Ainda um dia hei-de contar ao meu amigo o segredo das crises de fome em Cabo Verde. Ter eu começado a levantar uma ponta desse véu, ajudou a preparar essa situação em que ainda hoje me debato. [...] Eu ganhava quarenta escudos mensais n'A Voz: preferi ficar em péssimas circunstâncias, pobre e sem colocação, a ter de prestar o concurso da minha actividade à imoralidade dos açambarcamentos.

Para viver lancei-me a fazer versos e a vendê-los. É-me preferível vender maus versos, a estragar belos ideais com os prostituir comerciando-os. (Ibidem, pp. 212-213).

Mesmo perseguido e aviltado, Eugénio Tavares nunca desistiu de seus propósitos: falar aos cérebros, tocar o coração dos cabo-verdianos e despertar a consciência popular, como podemos depreender da missiva dirigida "Ao Povo Caboverdiano", na qual vigorosamente assim se pronunciava:

Falo-te, porém, não sei se me ouves; invoco quanto deve haver de levantado na tua alma, e a incerteza do teu olhar apenas me dá a impressão fria da caligem que envolve a tua inteligência, da miséria em que se empocilga a tua triste existência moral.

Fisicamente, eu sei, existes: bem te vejo sob a mó de um labutar esmagador, investindo com quanto há de tempestuoso na adversidade, para que não falte o pão na boca dos teus filhos. Moralmente, porém, 
não ouço a tua voz no concerto das vontades orientadas na disciplina e fortalecidas na união.

Vítima da dissolução do meio em que fadejas; pessoa civil sem valor real; força política sem consciência de direitos; dizer-te vivo para o dever, é caluniar a tua incapacidade cívica e intelectual (Ibidem, p. 220).

Questionando os cabo-verdianos sobre o desempenho dos detentores do poder, acrescentava:

O que têm feito, por ti, esses que, com proficuidade, podem exercer benéfica acção moral e política? Quando é que, para elevar o teu nível moral ou económico, sacrificaram, eles, a mínima parcela do seu tempo ou do seu dinheiro? Quando é que deixaram de baldrocar com a tua confiança? Quando se cansaram de abusar da tua ignorância?

Absorvidos pelos interesses da própria ceva quando foi que eles olharam para cima, para a constelação dos mais altos ideais humanos? Quando foi que eles viram, na política, não um meio de fazer frutificar habilidades em proveito próprio, mas uma força de fazer progredir povos? (Ibidem, p. 221).

O apelo endereçado ao povo, em estilo vibrante, sugere que este ("que dorme o sono cataléptico" porque "falta a compreensão dos seus direitos") lute por direitos políticos, educação, mobilize-se em causas coletivas e tenha senso de disciplina. Diante da miséria, do abandono, da injustiça e do desleixo por parte do governo colonial, interroga seus compatriotas: "Tu tens escolas para os teus filhos? Escolas em que eles possam aprender a ler, a escrever, a contar, a raciocinar, a amar a pátria?” E sublinha:

Deixares-te, porém, ficar aí onde estás, e como estás, é que não pode ser.

Essa indiferença, essa sovinice, dão contigo num vilíssimo suicídio moral. E tem por certo que, se te não precatas, se não abres os olhos, se te não deslodas, liquidas, mais tarde ou mais cedo, num contrato para S. Tomé, a três mil reis mensais por cabeça... (Ibidem, pp. 224-225).

A produção epistolar de Eugénio, como é possível observar, trata com energia os temas expostos no jornalismo, aponta saídas para as situações descritas e conclama o compatriota cabo-verdiano: "Escuta-me: exerce os teus direitos políticos; edifica escolas; terás duas portas abertas para as luminosas regiões da perfeita existência moral" (Ibidem, p. 225).

Em suma, como bem o observa Manuela Monteiro, Eugénio Tavares esgrimiu “o verbo com mestria, [...] deixou-nos trechos de intervenção memoráveis, cuja clarividência e lucidez ainda hoje nos surpreendem. A sua actividade como homem e 
cidadão, a sua actuação como escritor, explicam o respeito, a admiração e o carinho que continua a merecer" (TVTCP, p. 15).

E, acima de tudo, o seu amor por Cabo Verde credencia a sua produção em prosa e, conforme buscaremos comprovar adiante, a sua produção em verso, como marcos identitários de alto valor estético:

Amo tanto Cabo Verde que através de uma existência de lutas, de sofrimentos, com a minha carne lacerada e o espírito batido de decepções, ainda me esqueço de pensar em mim para pensar nele (TVTCP, p. 176). 


\section{CAPÍtulo II - A POÉTICA DE EUGÉNiO TAVARES EM LÍNGUA PORTUGUESA}

A falta de poesia significa, simplesmente, demasia de animalidade.

Eugénio Tavares

Eugénio de Paula Tavares fez o seu debut literário em 1882, publicando, aos quinze anos de idade, seu primeiro poema no Almanaque de Lembranças LusoBrasileiro. A estréia foi saudada com entusiasmo pelo também poeta bravense Luís Medina de Vasconcelos, cuja crítica reconhecia as qualidades do jovem aspirante a poeta, que muito prometia no cenário das letras cabo-verdianas.

Intitulado "A Badinha”, o poema é uma singela homenagem à sua mãe adotiva, considerando que Eugénio perdeu sua mãe biológica de complicações durante o parto, sendo logo adotado pelos irmãos José Martins da Vera Cruz e Eugénia Martins da Vera Cruz Medina e Vasconcelos. Coube aos dois dar as condições necessárias para que ele se tornasse um dos intelectuais mais destacados de Cabo Verde em todos os tempos.

Dona Eugénia era carinhosamente tratada por Badinha por Eugénio Tavares. Como reconhecimento pela dedicação, pela educação e por todo o carinho empenhados na sua criação, o futuro ilustre poeta da ilha das flores compôs o poema abaixo:

\footnotetext{
A Badinha

Um dia caíra em teu níveo seio desmaiado botão,

que d'uma linda roseira arrancara violento tufão.

As tuas carícias deram-lhe a vida, e o anelito teu

foi o bálsamo que deu força, alento ao débil peito seu!

E a carmínia bonina transformou-se rapidamente em flor,

que se esforça por derramar a jorros reconhecido odor!

O imaculado anjo da caridade, que do Olimpo desceu,

És tu! E a flor, que, meiga e carinhosa, embalaste, sou eu!
}

1882 (TPOLP, p. 69)

Produzida entre o fim do século XIX e as primeiras décadas do século XX, a obra poética de Eugénio Tavares era marcada ainda pelo peso de uma forte presença 
cultural portuguesa em Cabo Verde. A produção lusitana foi, neste momento, a principal referência literária dos escritores do arquipélago, uma vez que foram as estruturas coloniais que deram forma às suas instituições de ensino, à imprensa, às bibliotecas, enfim, a todo o seu edifício letrado, sendo os modelos providos pela metrópole os sustentáculos da base intelectual cabo-verdiana.

Como esclarece Antônio Carlos Oliveira Santos:

A poesia produzida nesse período nas colônias portuguesas da África caracteriza-se por um forte apelo sentimental e confessional de cunho ultraromântico. Apesar do anacronismo, essa produção reflete o convencionalismo estético dominante no imaginário coletivo da época (2007, p. 70).

Assim, a presença literária portuguesa foi decisiva para a formação de escritores e de um público letrado nas colônias.

Observaremos que os textos de Eugénio Tavares em língua portuguesa, produção que "só passa a ser conhecida e estudada a partir do excelente trabalho que Félix Monteiro fez da recolha em três livros da sua publicação dispersa"17 (BRITOSEMEDO, 2009, entrevista), cultivam a norma culta, sendo elaborados com critério e muito esmero com a língua de Camões. Há o uso deliberado de um vocabulário rebuscado, típico do estilo ultrarromântico, que torna mais opaca uma primeira leitura, à diferença dos textos em língua cabo-verdiana, que são visivelmente populares, por constituírem letras de mornas. Neste caso, a apreensão pelo leitor comum se torna muito mais acessível, já que os textos são expressos numa linguagem mais ingênua, simples, de forte apelo ao público em geral.

João de Deus, Camões, são mestres que Eugénio cultuará, inclusive com dedicatórias ("ao altíssimo espírito de João de Deus") e versões de poemas para a língua cabo-verdiana, como "Engeitadinha" e "Bárbara, bonita escrava", respectivamente.

$\mathrm{Na}$ poética em língua portuguesa, podemos afirmar, como Helder Garmes constatou na literatura das colônias, que o quadro de referências da cartilha romântica (ou das convenções ultra-românticas) do colonizador foi absorvido, especialmente nas suas vertentes sentimental e cristã (GARMES, 1999, p. 345).

\footnotetext{
${ }^{17}$ Refere ainda Brito-Semedo, em entrevista a nós concedida na cidade da Praia, Cabo Verde, dezembro de 2009: "O que as pessoas conheciam de Eugénio Tavares até relativamente pouco tempo (somente a partir de 2000 ele é reconhecido poeticamente, os livros são publicados e há interesse, e agora Eugénio é estudado ao nível das cátedras, das universidades), o que era conhecido de Eugénio Tavares era em termos da poesia, da morna, faceta bem popular (o popular, somente o popular). Portanto, só o popular, mas o erudito não era conhecido.
} 
A segunda geração romântica portuguesa (que despontou entre 1838 e 1865, data da "Questão Coimbrã", que elegerá o realismo como estilo), alçada a paradigma pelos literatos das colônias, exacerbava os traços expressos pela primeira geração, recebendo a tônica de sua produção a denominação de "ultra-romantismo", que ainda perdurará na terceira geração em Portugal. Dentre os escritores lusos cultores desse estilo, enumeramos: Maria Browne, Alexandre Braga, José da Silva Mendes Leal, seu irmão António Joaquim Teodorico Mendes Leal, Camilo Castelo Branco, Soares de Passos, João de Lemos, Luís Augusto Palmeirim, Gomes de Amorim, Bulhão Pato, Tomás Ribeiro, A. X. Rodrigues Cordeiro, Joaquim Pinto Ribeiro, Francisco Palha, Augusto Luso da Silva, J. S. da Silva Ferraz, Ernesto Pinto de Almeida, João de Deus.

António José Saraiva e Óscar Lopes referem que, na década de quarenta e sob a égide do padrinho António Feliciano de Castilho, surge uma leva de poetas, sobretudo entre os estudantes universitários de Coimbra, que escolhe como mestre Lamartine, praticando um

lirismo melancólico, desalentado, pessimista [...] numa glorificação sentimentalona [...] das velhas convenções domésticas, pátrias e religiosas [...]; a sintaxe exclamativa, repetitiva, com apóstrofes [...] cujo foco veio a ser a revista coimbrã $O$ Trovador (1970, p. 762).

Por volta de 1848, a Revista Universal Lisbonense d'Aldeia, em que pontificava Castilho, apontava a revista $O$ Trovador como paradigma a ser seguido, que "fixou, a passos largos, certos gostos em poesia que se identificam com certos estratos da burguesia portuguesa do século XIX” (Ibidem, p. 766).

Mais tarde, Soares de Passos encabeçará um grupo de poetas coimbrãos do grupo denominado O Novo Trovador (1851-1956), revista à volta da qual circularam ainda Alexandre Braga e António Aires de Gouveia.

No Porto e seguindo trilhas propostas n'O Trovador (de Coimbra), entre 1849 e 1855, as revistas A Lira da Mocidade, O Bardo, A Grinalda e Miscelânea Poética publicaram também textos com temas "ultra-românticos negros e lacrimosos" (FRANÇA, 1974, p. 726).

O quadro de referências impregnado pelo "mal-do-século" byroniano que esses poetas (que publicaram de 1838 até 1865) legaram aos literatos das colônias, inclusive a Eugénio Tavares, assim se caracterizava: escapismo, exílio, saudosismo; "pessimismo, insatisfação, melancolia, ânsia de absoluto, religiosidade cristã, pendor confessional, 
idealismo amoroso, elevada temperatura dos afectos, sentimentalismo burguês [...]; alguns cantam a Pátria e a Liberdade, denunciando aspirações sociais" (COELHO, 1979, p. 1125); para Vitor Manuel de Aguiar e Silva, o mal-do-século, ao qual acrescentava a volúpia do sofrimento e a busca da solidão, exprimiria o "cansaço e a frustração resultantes da impossibilidade de realizar o absoluto" (AGUIAR E SILVA, 1979, p. 481) aspirado pelo homem romântico.

Ao conjunto, no que toca à linguagem, podemos acrescentar: ênfase retórica (BRAGA, 1896, p. 359), oratória melodramática, teatralidade extrema, vocabulário requintado, muitas vezes terrífico e obscuro ("noir"), ligado ao campo semântico do "mal-do-século", personificado por Lord Byron, cuja poesia revelava um caráter marcadamente autobiográfico de homem exilado, pessimista, que desejava a morte como solução para um turbilhão de angustiados sentimentos e vivências.

Cabe ressaltar, nessa pausa esclarecedora das convenções ultra-românticas que nos facilitará a leitura dos poemas eugenianos em língua portuguesa, que

\begin{abstract}
os próprios românticos (Castilho, Garrett, Camilo) censuraram ou consideraram ridículos os excessos do Romantismo, a sua degradação pelo emprego de receitas ao gosto do público menos exigente [...] Castilho, em 1832, numa carta a J. V. Cardoso da Fonseca, usava pejorativamente o adjetivo ultra-romântico (tê-lo-á formado?) a respeito dum estilo declamatório que - supunha - não duraria muito tempo. [...] Camilo, em 1848, num artigo do Nacional, usa o adjectivo gongórico, no sentido de maneirista, a respeito da poesia do tempo: "Queria fazer-te uma poesia gongórica, como essas que por aí lês que não passam do rubim, carmesim, marfim - rosal, cristal, angelical..." (COELHO, Op. cit., p. 1126).
\end{abstract}

Sublinhamos, porém, que de uma produção ultra-romântica com altos e baixos, destacam-se bons poetas como João de Deus (já pertencente à terceira geração romântica lusa e poeta-modelo de Eugénio Tavares), João Lemos e Soares de Passos, encarnação portuguesa do funéreo "mal-do-século". Os dois últimos, pertencentes respectivamente ao grupo d'O Trovador e d'O Novo Trovador, tiveram textos popularizados e declamados tanto nas ruas quanto nos salões burgueses, como os antológicos "A lua de Londres" (poema de exílio e saudade da terra natal) e "O noivado do sepulcro" (que marca o apogeu da produção soturna ultra-romântica, publicado na revista $O$ Bardo, 1852). 
Explicitadas essas observações básicas para a leitura dos poemas de Eugénio Tavares em língua portuguesa, agruparemos a sua produção por temas relacionados ao núcleo ultrarromântico referido.

Adiantamos ainda que, neste capítulo, ao lado da temática lírico-amorosa que dominará tanto a produção poética eugeniana em língua portuguesa quanto (e sobretudo) em língua cabo-verdiana, e paralelamente à sua poesia em língua portuguesa de linhas ultra-românticas, buscaremos também delimitar outras linhas que possibilitem uma leitura comparatista da obra poética no seu conjunto, como: o terra-longismo caboverdiano, os dramas do arquipélago, o humor.

\section{1 - O núcleo ultrarromântico: amor idealista e mal-do-século}

Pode-se dizer que Eugénio talvez fosse um poeta do amor idealizado, no fundo do amor nunca encontrado, no amor romântico e inconcebivel.

Vasco Martins

No contexto do quadro de ressonâncias ultra-romântica aludido acima, o idealismo amoroso é, sem dúvida, um dos núcleos privilegiados na produção de Eugénio Tavares, associando-se a ele os temas do desengano, da tristeza, da dor, da melancolia, da saudade, da solidão, da noite, do sonho, da morte, entre outros.

O poema "Chico e Berta", por exemplo, apresenta o colóquio amoroso de início em cena que evoca a ilha natal de Nhô Eugénio, a Brava. Vejamos:

Quando nasceu o sol do vosso imenso Amor

Estava o céu azul, sereno, aveludado,

Era na primavera, e o vale atapetado

De flores, era o ninho ideal do vosso Amor.

Gorgeou a Toutinegra; entreabriu-se a Flor!

O Som e a Cor, bem como o par enamorado,

Em loucuras pagãs, rolavam pelo prado

Cantando o vosso Amor - a Toutinegra e a Flor...

Depois, um triste dia, ergue-se a Sombra negra:

$\mathrm{O}$ vento desfolhou a Flor; e a Toutinegra

Emudeceu de horror nos verdes laranjais...

Volta a sorrir o Sol? Rescendeu o rosmaninho?

De novo a Toutinegra entoa madrigais? 
Sede felizes! Deus festeja o vosso ninho!

Brava, 14/6/908 (TPOLP, p. 17, grifos nossos)

Já no capítulo anterior, quando comentávamos as "Cartas para a América", endereçadas ao amigo Inocêncio Simplício, ressaltávamos "a surdina suave dos prelúdios amorosos das toutinegras" e "a natureza [...] espreguiçando-se e sorrindo castamente pelas bocas perfumadas das flores" (TVTCP, p. 193) que o poeta Eugénio Tavares inscrevia no paraíso da Ilha Brava, chamada em Cabo Verde de "ilha das flores". Para outro poeta, Jorge Barbosa, o

seu amor à ilha natal chegava a ser idolatria, um sentimento exaltado e profundo. Toda ela viveu nos versos de Eugénio: a Natureza acidentada e fértil, as flores que nascem espontâneas pelos caminhos e pelas encostas, e as que mãos cuidadosas cultivam nos jardins, o aroma que a deslocação do ar volatiliza, o clima bendito, as cumeadas dos montes aneladas de névoa, e o fundo pedregoso dos vales, o conflito psicológico dos passionais, o drama sentimental dos emigrantes que em terra distante contam os dias para o regresso à ilhaberço... (BARBOSA, Notícias de Cabo Verde, 31/05/1931, TPJ, p. 302).

Assim, a paisagem de fundo do poema, solar e serena de início (como as descrições eugenianas da ilha Brava), transforma-se num cenário "triste", de "horror", toldado pela "Sombra negra" do clima ultrarromântico da terceira estrofe, sob o signo da doença, da morte ou do envelhecimento, isto é, da passagem do tempo. Os verbos marcados pela negatividade, como "desfolhou" e "emudeceu", sugerem um romance que sofreu percalços. No entanto, a quarta estrofe do soneto deixa em aberto, com as interpelações do sujeito poético, o destino dos enamorados Chico e Berta, aos quais deseja, com o auxílio da religiosidade católica, o restabelecimento da felicidade no seu ninho de amor.

O texto, embora apresente circularidade centrada no vocábulo "ninho" (primeira e última estrofes), sugere um amadurecimento da relação amorosa.

Quanto à sintaxe, o estilo exclamativo (“Deus festeja o vosso ninho!”) e interrogativo ("Volta a sorrir o Sol? Rescendeu o rosmaninho?”), enxertado ainda pelo apostrófico (“Sede felizes!”) e pelo hiperbólico (“imenso", "horror”) é caro aos padrões ultrarromânticos lusos.

Outro soneto vai debruçar-se sobre o tema do júbilo do amor e da conseqüente perda da felicidade, recorrendo a vocabulário semelhante: 


\section{Sempre Adorada}

Desce comigo ao fundo deste horror De ver, talvez, bem longe ainda o dia, $\mathrm{O}$ dia de acordar para a alegria Meu coração turbado pela dor:

Desce comigo a este inferno, Amor;

À geleira da minha nostalgia;

Desce comigo, santa, e avalia

O que resta de tanto sonho em flor!

Entre os escombros da felicidade

Que, na ilusão gentil de curtos anos,

Juntos erguemos numa esperança infinda

Tu verás, no regaço da saudade,

Mal ferido do mal dos desenganos

Minha alma, doida, a te adorar ainda!

(TPOLP, p. 19, grifos nossos)

$\mathrm{Na}$ primeira quadra, a atmosfera de "horror" perdura e sua causa é clara: a "dor" do eu lírico, que apela à amada que a compartilhe com ele ("desce comigo").

$\mathrm{Na}$ segunda estrofe, em verso paralelístico, o horror se intensifica em "inferno" e a "nostalgia" explica a causa do sentimento conturbado ("coração turbado", "alma doida") do eu poemático: a frustração de sonhos que possivelmente não foram realizados (“O que resta de tanto sonho em flor!”). Adensando o sentido do texto, o primeiro terceto torna mais intensa a carga trágica dos "restos" de esperanças também partilhadas ("juntos") em "escombros da felicidade" e, finalmente, o último terceto revela o "mal" maior ou o "desengano" máximo: a "saudade" da mulher adorada.

Os substantivos hiperbólicos ("horror", "inferno", "escombros”), conjugados a advérbios de intensidade ("bem", "tanto") caracterizam também o exagero nos sentimentos e situações que o eu lírico exprime.

Como no soneto anteriormente examinado, a passagem do tempo aponta para um índice de negatividade ("ilusão de curtos anos", mas de "esperança infinda") que se materializa no afastamento dos amantes, suposto no sentimento de saudade. Contudo, a paixão platônica do eu lírico ("santa", "adorada") persiste, como o comprova a chave de ouro do soneto, em tom exclamativo: "Minha alma, doida, a te adorar ainda!"

A saudade do primeiro amor retoma mais um núcleo romântico, o regresso ao passado, aliado ao sonho. A passagem do tempo é recorrente na poética eugeniana: 


\section{A Valsa}

Aos meus amigos João Henriques de Almeida e Rogério Vasco

Rompeu a valsa nos bordões tão graves

Da guitarra. Sonhando vagamente,

Revoa o meu espírito doente

Num ângelus de lágrimas suaves.

Crescendo no horizonte, como naves

Que regressam, num pálido poente,

Os dias que morreram, tristemente,

Voltam em bandos, como bandos de aves.

Plúmbeas recordações duma outra idade

Chegam nas asas roxas da saudade,

E acordam a minha alma para a dor...

Eu vou sonhando: o meu primeiro amor

Abeira-se de mim. Falo-lhe: Flor!

É isto sonho, ou é realidade?

(TPOLP, p. 19)

As metáforas aéreas, que representam a capacidade de regressar no tempo, como os dias que "voltam em bandos, como bandos de aves" e as recordações que "chegam nas asas roxas da saudade" associam-se ao campo do sonho, tão caro à retórica romântica. A hipérbole ou o exagero, aqui, intensifica a carga daquelas recordações (“crescendo no horizonte, como naves") que povoam a memória, no momento presente (“pálido poente”) melancólico do eu poemático.

A tristeza ("lágrimas") do "espírito doente" pelos "dias que morreram" e a "saudade" são amenizadas, como podemos observar, pela música da guitarra portuguesa (semelhante à que Eugénio usava para compor as suas mornas), que impulsiona as recordações (do latim re + cor, cordis, ou trazer de novo ao coração) do primeiro amor e de tempos mais felizes ("outra idade"). Cabe observar as cores que se misturam com os sons da valsa: cinza ("plúmbeas recordações") e roxo ("asas roxas da saudade"), tendendo para um clima noir, soturno, próprio do ultra-romantismo.

Essa atmosfera soturna e noturna se adensará nos poemas seguintes, "Os tristes" e "Noite infinda":

\section{Os Tristes}

Quando os tristes sofriam, torturados, Eu deles me acercava, despertando A coragem, o bem, suave e brando, $\mathrm{Na}$ alma ferida dos abandonados. 
Depois, quando os punhais envenenados Me foram pouco a pouco trespassando, Então os tristes, pálidos, em bando, Me cercaram em lágrimas banhados.

Lançaram nos meus ombros suas mantas;

Os braços seus me foram travesseiras;

E quando as aves de rapina, arteiras,

Voltearam sobre mim, as almas santas

Dos tristes, como Mães me defendiam,

Sobre o meu lar as asas estendiam...

(TPOLP, p. 21)

O pathos pessimista ("tristes sofriam", “torturados", "abandonados"), associado ao mal-do-século, expressa-se numa retórica melodramática ("punhais envenenados trespassando") e terrífica (“aves de rapina”), típica da oratória ultrarromântica.

O poema "Noite Infinda", associando-se a essas trilhas, continuará a trabalhar o campo semântico dos sentimentos, da melancolia saturnina típica do ideário ultrarromântico referido.

A aurora virginal, todos os dias,

Da noite lá nas horas derradeiras,

Vem lavar as montanhas e as ribeiras

Da caligem das sombras fugidias:

Raro, porém, à voz das cotovias,

Como um bando augural de mensageiras,

Da irremediável Dor sobre as geleiras

Sorriem, de regresso, as alegrias!

Não há noite, por mais aterradora,

Por mais cheia de sombras e visões,

Que não finde por uma madrugada:

Mas, neste mundo, quantos corações

Se mergulham em treva tão pesada

Que nunca mais uma alvorada as doura!

Janeiro de 1900 (TPOLP, p. 21, grifos nossos)

A noite "aterradora" e a "treva tão pesada" simbolizam as emoções humanas sob o signo do astro baço, Saturno. A atmosfera fantasmagórica de "sombras e visões" ou de "sombras fugidias" e de Dor (com maiúscula alegorizante) parece, até a terceira estrofe, obstáculo a ser vencido pela luz solar da madrugada: "A aurora virginal, todos os dias,/ Vem lavar as montanhas e as ribeiras/ Da caligem das sombras fugidias [...]". 
Com "a voz das cotovias", eco do texto shakespeariano Romeu e Julieta, modelar do discurso amoroso ocidental, "sorriem, de regresso, as alegrias", o que redundaria na conclusão: "Não há noite, por mais aterradora,/ Que não finde por uma madrugada". As cotovias seriam, como no texto do mestre inglês, "os arautos da manhã" (as "mensageiras", no poema de Eugénio Tavares).

Embora este fosse um raciocínio lógico para a leitura menos atenta do poema, um adjetivo - "raro" -, associado às cotovias (canto que separava os amantes ao anunciar, na tragédia de Shakespeare, o raiar do dia), faz soar um alarme: o regresso das alegrias é "raro" e a "Dor" persiste. Como no texto de Shakespeare, em que o amor acaba por não se realizar plenamente no mundo do real e o verdadeiro (des?)encontro dos amantes se dá na morte.

Portanto, a conjunção adversativa ("Mas"), que inicia o último terceto, levanos a entender que, na verdade, o que se afirma é o oposto do aforismo "Não há noite, por mais aterradora,/ Que não finde por uma madrugada": a proposta do poema é que "Neste mundo, quantos corações/ Se mergulham em treva tão pesada/ Que nunca mais uma alvorada as doura! A expressão em grifo parece a fala do corvo, de Edgar Allan Poe, em seu poema considerado de "romantismo negro": Nevermore, nevermore (Nunca mais, nunca mais!)

O poema "Réstea de luz", conjugando-se ao núcleo dos desencontros de amor, propõe a fugacidade da presença feminina ao lado do amante: ela desperta os seus sentimentos e logo se vai.

Fizeste mal em me acordar. Agora Entrou-me na alma o teu olhar; e logo Ergueu-se a ti todo o meu ser, em fogo Como um vulcão dourado pela aurora.

Eu quisera dormir até à hora

Da morte - o mar de sombras em que afogo Meus males todos... Flor, ouve o meu rogo:

Não me despertes, foge; vai-te embora.

Ainda ficasses a meu lado, E nunca mais de mim tu te afastasses... Mas, como sonhos tímidos, fugaces,

Chegas sorrindo, partes a chorar, Deixando-me a curtir, abandonado $\mathrm{Na}$ dor de te perder sem te beijar... 
O olhar da amada provoca no eu poemático um turbilhão de sensações ("fogo”, "vulcão", "afogo") que não poderá ser vivido em plenitude, porque um afastamento é anunciado ("foge", "perder sem te beijar"), culminando no estado de solidão: “abandonado".

O amor, como no texto de Camões, é um estado hiperbólico, "é fogo" ("que arde sem se ver"), "vulcão dourado pela aurora", mas que, contraditoriamente, se converte em "males" e "dor" (em Camões “dor que desatina sem doer").

A amada, quando surge, o faz sempre num contexto luminoso, de aparição platônica, como podemos observar no poema a seguir.

Em mim já é, toda a felicidade, Efeito de uma causa conhecida: Feliz me sinto sempre na medida Que em ti o bem rebrilhe, sobrenade.

Dos teus sorrisos vem a claridade Que veste e que ilumina minha vida; Assim, do sol, a lua dolorida, Toma esse ideal reflexo de saudade... Inspiram-se nos teus os meus desejos. Só amo o que tu amas. Teus juízos São meus faróis da Dúvida nos brejos.

Contigo são-me, infernos, paraísos, E na glória suprema dos teus beijos, Reflexos são dos teus, os meus sorrisos.

Dezembro de 1914 (TPOLP, p. 24, grifos nossos)

Produto mais de contemplação do que de uma convivência real ou realização carnal, o amor, "efeito de uma causa", depende das reações da mulher amada e se torna reflexo de sua presença, desejos, atos: "inspiram-me nos teus os meus desejos", "reflexos são dos teus , os meus sorrisos".

O eco camoniano na poética dos nativistas cabo-verdianos, já ressaltado por Gabriel Mariano em entrevista concedida a Michel Laban (LABAN, 1992, v. 1, p. 326), parece evocar o célebre poema "Transforma-se o amador na cousa amada". E transforma-se por virtude do "muito imaginar".

Portanto, o núcleo neoplatônico da poética camoniana é conservado na poética de língua portuguesa de Eugénio Tavares.

Eugénio retoma a definição do amor como fenômeno contraditório, resumida no soneto camoniano "Amor é fogo que arde sem se ver": 


\section{O Mal de Amor}

\section{(Coroa de espinhos)}

\section{Prelúdio}

O amor é semelhante a uma planta Com flores de oiro e espinhos peçonhentos, Que a uns a existência eleva e encanta,

E a outros só confere sofrimentos.

Há esse amor que aclara e que enobrece, E ess'outro que prostitui e mata:

Amor astro e amor raio; santa prece,

Ou vergonha que a morte só resgata.

$\mathrm{O}$ amor letal não menos nos seduz Que o doce amor vital do nosso lar: Iguais na sua força, iguais na luz, O próprio Deus se ilude em os coroar...

Quanto uma sorte escura nos arrasta Ao doce mal do amor; os nossos olhos Fecham-se à luz; e nada nos afasta De um destino de lágrimas e abrolhos.

Coroas tece o amor, de brancos lírios E de espinhos em garras de condor... A uns, flores; e a quantos mais martírios!... Eis a eternal religião do amor!

Está nas mãos de Deus e de quem ama, Beijar, sem sangue, os lírios lactescentes... Que culpa tem a inofensiva chama Que a busquem, cegas, asas inocentes?

É porventura a luz que corre após A borboleta no seu voo incerto?... O amor é Deus, e é um mal atroz? Infinito de luz, e abismo aberto?

O sol dá cor às pétalas das rosas, E põe rosas nas faces das crianças: Mas são, seus raios, setas venenosas:

Fulminam vidas, matam esperanças.

Assim o amor, essa razão suprema Da vida: eleva, salva, diviniza: De par, porém, arrasta à mais extrema

Miséria, e a honra, às vezes, desraíza,

O Amor e o Sol! Eis as bases da vida! Toquemo-los apenas com os lábios: 
Queimam a borboleta enlouquecida,

Mas dão felicidade e luz aos sábios...

Atende, filha, e vê: nunca houve abismo

Para as aves do céu? Minha Alegria!

Desdobra as asas desse idealismo

Sentimental e forte que te guia!

Já me não treme o coração receoso

De ver o mal do amor, a tempestade,

Toldar de sombras teu perfil radioso,

Velar-te a ilusão Felicidade.

(TPOLP, pp. 44-45, grifos nossos)

As metáforas que definem o amor (mais especificamente, o "mal de amor”) são sempre expressas antiteticamente, como no texto camoniano. Frequentemente associado ao Sol e à claridade, o Amor, sempre sob o signo de um "idealismo sentimental", pode ser "santa prece" ou "vergonha", "vital" ou "letal", "luz" que traz "felicidade" ou que "queima”, força que "eleva, salva, diviniza/ De par, porém, arrasta à mais extrema/ Miséria", "sol" que "dá cor às pétalas das rosas", mas cujos "raios, setas venenosas [...]/ Fulminam vidas, matam esperanças.

Mas esse fenômeno constitui-se mais complexamente, porque os estados contraditórios acabam por ser inclusivos, expressando-se em oximoros, nos quais Camões é um mestre, que unem os opostos: "flores de oiro e espinhos peçonhentos", "esse amor que aclara e que enobrece,/ E ess'outro que prostitui e mata", "Infinito de luz, e abismo aberto".

O prelúdio do mal de amor descreve o início, quando o amor começa com força total e igual luz, daí, além do uso das antíteses e oximoros, Eugénio Tavares emprega um vocabulário enfático e hiperbólico para sugerir ao leitor como se sentiria o eu lírico em estado de paixão: "eleva”, "encanta”, "enobrece”, "prostitui", "mata", "felicidade", "sorte escura" (destino), "extrema miséria”, “enlouquecida”, "abismo".

Este "amor astro e amor raio", que dispara setas a esmo qual Cupido cego, poderá tecer "coroas" "de brancos lírios" e/ou "de espinhos", "flores" ou "martírios". No entanto, no subtítulo do texto, o eu poemático opta pelo pólo pessimista da equação: a coroa é "de espinhos", no melhor estilo ultrarromântico religioso cristão.

O mal do amor pode ainda originar-se do afastamento da amada ou da ausência, como no poema "Epílogo": 
Ó meu amor! Ó minha companheira,

Que de tão longe ao meu suplício assistes!

Esta me seja a hora derradeira,

Que outras não poderei viver mais tristes!

Ó meu primeiro, e meu único amor!

Ó coração ausente de meu peito!

Requer à sorte abrande seu rigor

Antes que abata o meu sonho desfeito!

Ó minha honra! Ó minha santa cruz,

Da qual me vem o golpe e a resistência!

Tu és a força imensa que reduz

Todo o meu mal a esta dor da ausência!

Ó luz vital dos meus olhos ausente!

Ó mão piedosa que me ampara e guia!

Milagre que me sara e deixa doente

Vivo p'ra a dor, e morto p'ra a alegria!

Estás longe de mim e é maravilha

Que eu possa inda viver nesta orfandade

Do teu amor, em noite onde não brilha

A esperança, consolo da saudade!

Estou longe de ti, e o céu destila

Nos lábios meus o travo da cicuta!

Mas da tua alma plácida, tranquiila,

Me vem toda a coragem para a luta.

Terei na minha frente o horror da queda?

Que importa? Amparam-me teus braços santos!

Envolve-me do ódio a labareda?

Salvar-me-á o orvalho dos teus prantos!

Quando a Traição me estende sua mão

De dedos que laceram como puas,

Nenhum golpe me atinge o coração

Neste refúgio das virtudes tuas.

É este amor que eleva e fortalece!

É este o amor que aclara e dignifica!

Diante de sua força augusta, cesse

Quanto de nobre a fama testifica!

E semelhante às rochas duras, frias, Que esbofeteia em vão o mar rugindo, Em vão do mal as raivas mais sombrias Tentam ferir-me, na alma te ferindo!

Não há poder que vença o grande amor $\mathrm{Na}$ honra renascido e coroado! A nós, Deus no-lo deu assim. E a dor Aumenta, apenas, seu fervor sagrado. 
Meus lábios lançariam maldições

Se o Beijo os não tivesse redimido!

Meu peito sonharia más acções

Se o teu amor mo não tivesse ungido!

Beijo de amor! Hóstia santificada!

Tu és a cruz de sangue que redime!...

Se em toda a terra foras tu hasteada,

De toda a terra fugiria o crime!

Março, 1916 (TPOLP, pp. 63-65, grifos nossos)

Podemos observar na quarta quadra do poema o uso dos oximoros para expressar que o eu poemático sofre com a ausência da amada (talvez por morte?), mas nela também se fortalece o idealismo amoroso, na medida em que o amante tem o "consolo da saudade".

Este amor, santificado por um vocabulário religioso cristão ("hóstia", "santa cruz", "braços santos", "fervor sagrado", "ungido", "cruz de sangue que redime”), "eleva e fortalece [...] aclara e dignifica", transformando aquele que ama em virtude da nobreza do objeto amado.

Por fim, o tema culminante desse núcleo teatralizado que constitui o espírito de época ultrarromântico é a morte que, como no texto Romeu e Julieta de Wiliam Shakespeare, acaba por consagrar os amantes:

\section{Para a Vida e para a Morte!}

Como Laura a Petrarca, se encontraram Um dia; e seus olhares, confundidos Num raio férvido de amor, cantaram, De luz epitalámios comovidos.

Uma linda manhã, o sol rompeu $E$ lhes doirou as frontes inclinadas Diante de Deus; e, remontando o céu, Partiram suas almas enlaçadas.

E foram caminhando alegremente Pelas áleas da vida, entretecendo As plumas do seu ninho, numa ardente Intuição do bem o mal vencendo.

Em certo passo alçou-se a tempestade Nas sombras do destino encastelada: Fechou-se torvamente a escuridade Numa tremenda ameaça concentrada:

Uma volta de mar os separou:

A Ele a vaga ergueu-o revoltada: 
Ela, muda de espanto se abraçou

Aos pés gelados de uma cruz de estrada.

Qual maior dor? Qual mais funda agonia

Qual peito mais ferido e resignado?

Ela abraçada à sua cruz sombria?

Ou Ele, nessa cruz crucificado?

O mar e o vento, como salteadores

Que atacam pela estrada os viandantes,

Seus peitos separaram, seus amores,

Mas não seus corações fiéis, constantes.

Se declinava a fúria da tormenta

De novo os dois santelmos ressurgiam

Na noite negra, numa viagem lenta,

Buscando-se nas trevas que se abriam.

Debalde o mar voltava a rebramir!

$\mathrm{O}$ vento, em vão soltava roucas pragas!

Conta o poder do Amor, vinha ruir

Toda a força dos ventos e das vagas.

Depois? Depois, ainda, é o futuro,

O futuro nem sempre impenetrável...

(O Mal, mesmo que o vejas torvo e escuro,

Não é, tu podes crer, interminável)...

Supõe, lá mais adiante, uma bonança

Sem refregas, traições; sem laços reles...

Não vês dois vultos, pela tarde mansa,

Unidos, graves, plácidos? São eles...

Qual foi a força que lhes deu vitória

Nessa batalha horrível contra o mal?

$\mathrm{O}$ amor que salva! A soberana glória

Do coração a víscera imortal!

Unidos na alma, a vida percorreram.

E embora os separasse dura sorte,

Unidos combateram e venceram,

Unidos para a vida e para a morte...

(TPOLP, pp. 60-61)

O poema, dialogando com o Cancioneiro de Petrarca e elegendo como tema um dos amores mais idealizados da história da literatura, na sétima quadra refere ainda o contexto religioso-cristão para dignificar a força daquele amor, impossível na vida terrena - "seus peitos separaram", pois Laura era casada - contudo, que transcende a morte ("Mas não seus corações fiéis, constantes", "unidos para a vida e para a morte" por "epitalâmios" ou cantos nupciais). 
O poema "O sonho" compensa a distância amorosa e propõe a realização do amor na "outra vida", para além da morte:

Quando um dia eu voltar desta viagem,

Hei-de trazer-te o Sonho cuja ausência

Te tem posto pesares na existência,

$\mathrm{Na}$ tua vida branda como aragem.

Se eu lá ficar, porém, nessa miragem

Que acolhe os tristes cheia de clemência

Há-de voltar a ti a vaga essência

De eterno amor, em pálida romagem.

Minha alma há-de voltar a contemplar-te

E hás-de ouvi-la, num choro doloroso

Rogar a Deus de ti jamais a aparte.

E quando soar-te a hora da partida,

Como um par, de andorinhas, amoroso,

Iremos, juntos, desta à outra vida.

(TPOLP, p. 13)

Vasco Martins, a respeito da poética de Eugénio Tavares, tanto em língua portuguesa quanto em crioulo, ressalta "o extremo romantismo" cujos traços mais relevantes buscamos demonstrar.

Para o investigador e maestro,

A noção de Amor em Eugénio Tavares justifica, é claro, uma época romântica, uma estrutura poética condizente com os estados espirituais também do próprio poeta, que diz possuir pela mulher uma paixão sensível (MARTINS, 1989, p. 87).

Examinemos ainda os tópicos do exílio, do escapismo e do saudosismo, também constituintes do ultrarromantismo, que se conjugarão com o núcleo contextual da série literária cabo-verdiana que Manuel Ferreira denomina de "terra-longismo".

\section{2 - O núcleo do "terra-longismo"}

toda a partida É potência na morte E todo o regresso É infância que soletra 
O crítico português-cabo-verdiano Manuel Ferreira, em $O$ ciclo do mar e o “terra-longismo” em “Chiquinho" de Baltasar Lopes, estabelece a distinção entre emigração e evasão, ao comentar sobre os "construtores da verdadeira literatura caboverdiana", nos seguintes termos:

As razões agora da hora di bai definem-se em novos parâmetros. No primeiro caso os homens são acossados, empurrados. Resistem, mas a alternativa seria a de muitos outros: morrer de fome. Daí que se possa para este caso encontrar a emblemática designação: Querer-ficar-e-terde-partir. No segundo caso são os próprios entes torturados pela ânsia de correr mundo, ver as "cidades / terras distantes / que apenas sei existirem / por aquilo que se diz..." (Jorge Barbosa). O Mar, porém, está ali a limitar-lhes os passos. O Mar ali funciona como as grades de uma prisão. Então diríamos: querer-partir-e-ter-de-ficar. Eis como o terra-longismo, em literatura, se bipolariza: um de raiz económica, outro de raiz intelectual. $\mathrm{O}$ de raiz económica detecta-se principalmente na ficção e também na poesia. $O$ de raiz intelectual, se a memória não nos falha, apenas na poesia. $\mathrm{O}$ primeiro porventura $\mathrm{o}$ mais autentico, o profundamente real e vivido. O segundo depende: uma certa autenticidade deixa tal-às vezes contaminar-se de literatura. O primeiro uma constante sócio-económica cabo-verdiana. O último, explosivo do período que decorre na década 30-40, com tendência para ser contido mercê de uma visão ganha na consciência da necessidade de se fincarem os pés e a vida ali no chão da terra madrasta, mas apetecida. Ao primeiro chamaríamos de emigração. Ao segundo de evasionismo (FERREIRA, 1972, p. 68).

A emigração, frequentemente, associada à dor na poética de Eugénio Tavares em língua portuguesa, negativiza o "partir" com o sentimento de saudade (um dos microtemas do núcleo ultrarromântico). O campo da emigração é de pranto, de amargura, de mágoa que se opõe à alegria do regresso. Esse é o grande dilema dos poemas pertencentes a esse núcleo.

\section{Partindo}

Triste, por te deixar, de manhãzinha Desci ao porto. E logo, asas ao vento, Fomos singrando, sob um céu cinzento, Como, num ar de chuva, uma andorinha.

Olhos na Ilha eu vi, amiga minha,

A pouco e pouco, num decrescimento, Fugir o Lar, perder-se num momento

A montanha em que o nosso amor se aninha.

Nada pergunto; nem quero saber

Aonde vou: se voltarei sequer;

Quanto, em ventura ou lágrimas, me espera. 
Apenas sei, ó minha Primavera,

Que tu me ficas lagrimosa e triste,

E que sem ti a luz já não existe.

(TPOLP, p. 11)

No poema "Partindo", logo de início, o sujeito poético expressa o sentimento que dominará a famosa morna "Despedida", em língua cabo-verdiana, texto no qual nos deteremos no capítulo seguinte:

\section{Despedida}

(Marinheiros que partem)

Es mágua de nha partida

El sâ tâ matam nha bida!

Se'n bai, ramede que tem,

É'n bai, 'n tornâ bem.

Mas es tristeza de'n bai,

De'n bai pa'n largâ nha Mai,

El ca triste comâ dor

De'n bai pa'n largâ nha Amor.

No cantâ co água na ôjo;

No bajâ co alma de nôjo:

Hora triste de partida

É hora de perdê bida.

Quem que ficâ, ca ta bai:

Quem que ca bai, ca ta bem:

Força que pincha'n pa'n bai,

É bo, esperança de bem!

Ó bai, ó bai, ja bo triste!

Ouro de mar, ja bo caro!

Ó bem, ó bem, ja bo doce!

Dia de bem, ja bo claro!

$\left(\right.$ TMCC, p. 47) ${ }^{18}$

Embora a forma do poema "Partindo" seja o soneto, uma "casa poética" ou forma fechada, como propõe Maria Alzira Seixo (1977, p. 283), Eugénio retrata uma cena dinâmica de mar em aberto, de emigração, como o comprovam os versos do segundo quarteto: "Olhos na Ilha eu vi, amiga minha,/ A pouco e pouco, num

${ }^{18}$ Tradução da morna: Despedida (Marinheiros que partem) - Essa mágoa da minha partida/ Está matando a minha vida /Se eu for, remédio não tem, /Eu fui e voltei. /Mas essa tristeza de partir /De partir e deixar minha mãe, /Isso não é triste como a dor /De partir e deixar meu Amor. /Cantamos com água nos olhos; /Dançamos com a alma de luto: /Hora triste de partida /É hora de perder a vida. /Quem fica, não parte:/ Quem não parte, não volta: /A força que me empurrou para ir /És tu, esperança de voltar!/Ó partida, ó partida, tu és triste! /Ouro do mar, tu és caro! /Ó volta, ó volta, tu és doce! /Dia do retorno, tu és claro! 
decrescimento,/ Fugir o Lar, perder-se num momento". As expressões grifadas produzem no receptor do poema uma sensação visual de movimento quase cinematográfico, posto que dão a perceber o afastamento do navio que deixa a ilha, cujas dimensões vão diminuindo gradativamente com a distância.

O sentimento que preside o texto é de tristeza, mágoa do eu lírico na hora da partida, no momento em que o navio deixa o porto e o lar se transforma numa imagem fugidia, juntamente com a imagem de mulher amada:

O uso de iniciais alegorizantes (Ilha, Lar, Primavera) demonstra a relação de pertencimento à ilha natal, a Brava, conhecida em Cabo Verde como "a ilha das flores".

Ao mesmo tempo em que, em sua produção jornalística e epistolar, Eugénio Tavares caracteriza-se como um cidadão luso, paralelamente, na poética, opta por situar o seu Lar na sua Ilha e, por extensão, no arquipélago de Cabo Verde. Esse dilema, na época colonial, vai expressar-se com freqüência nos textos dos poetas denominados nativistas, que, mesmo considerando a sua cidadania lusa, já propugnam que os olhares se voltem para as ilhas de Cabo Verde, antecipando um sentimento de pertença que conduzirá mais tarde ás lutas de libertação.

Voltando à análise do poema "Partindo", a comparação estabelecida no verso: "Como, num ar de chuva, uma andorinha" pode conduzir a leitura ao tema da migração cabo-verdiana, pois que a andorinha é uma ave de migração, característica marcante da cultura das ilhas crioulas. O cabo-verdiano não migra apenas para outros países, mas entre as ilhas, uma vez que a condição climática do arquipélago muitas vezes força o ilhéu a buscar em outros espaços uma melhor qualidade de vida ou mesmo a possibilidade de sobrevivência.

Ainda que o eu lírico não revele neste poema, muitos são os motivos que levam o cabo-verdiano a deixar o arquipélago. João Lopes Filho afirma que

A pequenez da ilha, confrontada com a vastidão imensa do oceano, sedimenta e gera sonhos, porque um espaço insular como é o de Cabo Verde, condensa problemas de ordem natural e de ordem social (a seca, o isolamento, a fome, a pobreza, a doença...), que aumentam, constantemente, o desejo de procurar uma possível melhoria das condições de vida noutras paragens (LOPES FILHO, 2007, p. 27).

Em "Partindo", melancólico, o eu lírico, além de não revelar o motivo da partida, prefere não saber aonde vai e se voltará um dia. Por isto a saudade está sempre embutida no sentimento de quem parte. 
Partir, para os cabo-verdianos, embora constitua por vezes uma necessidade, é sempre um ato doloroso por deixar a terra amada e aqueles que amam. Por isso, muitos preferem evitar a "Despedida":

Dirás à minha pobre mãe, coitada! Que me perdoe não ir, na despedida, Beijar-lhe a grave fronte tão querida, Beber-lhe o santo olhar, benção sagrada;

Porque me traz esta alma tão quebrada A dor inconsolável da partida, Que, triste como os que se vão da vida, Nem quero ver-lhe a fronte magoada.

Dirás que levo uma saudade funda Dentro do coração angustiado!

Que a dor é tanta, em suma, e tão profunda,

Que me parece, até, ter começado A morrer, neste lúgubre momento Em que o navio esfralda asas ao vento.

(TPOLP, p. 11)

Se na morna "Despedida", mais acima registrada, Eugénio se expressa na forma popular da quadra e em língua cabo-verdiana, neste poema "Despedida", em língua portuguesa, o poeta desenvolve no soneto, forma fixa erudita, a mesma temática tão presente no cotidiano do ilhéu.

Ressalte-se neste poema o trabalho do poeta com a sonoridade dos versos, que ressalta a dureza da "dor" da despedida (aliteração do fonema "d"). A angústia do eu lírico também se manifesta por meio da gradação: "Que a dor é tanta, em suma, e tão profunda,/ Que me parece, até, ter começado/ A morrer neste lúgubre momento/ Em que o navio esfralda asas ao vento".

O momento da despedida, muitas vezes era sentido como um momento de luto para o cabo-verdiano, uma vez que quem partia, na época colonial, poderia nunca mais voltar pelos riscos traiçoeiros do mar, por viajar em embarcações rudimentares, para trabalhos insalubres, entre outros motivos.

A mãe a que se refere o poema pode ser associada à terra cabo-verdiana, "querida" e "sagrada", considerando-se o grande apego que Eugénio Tavares devotava ao arquipélago e as circunstâncias em que precisou afastar-se dele. 
A vontade de ficar, manifesta pelo eu lírico, é superada pela partida de um navio "insensível" que "esfralda asas ao vento" ou velas impulsionadas pelos fortes ventos cabo-verdianos que apressam o afastamento indesejado de quem parte querendo permanecer na ilhas.

Segundo Luís Silva, em seu artigo "Os exílios na literatura caboverdiana" (2006, p. 23), "Cabo Verde nasce do cruzamento de exílios, resultantes de deportações e da escravatura". O pesquisador enfatiza ainda que o primeiro texto da literatura caboverdiana sobre o exílio é de autoria de Eugénio Tavares, de 12 de Junho de 1900, intitulado "Rumo ao exílio", incluso nas "Cartas para a América" endereçadas ao amigo Inocêncio Cândido Simplício. Nele, Eugénio descreve uma viagem de vinte e nove dias, entre tempestades e calmarias, os serviços de emigração na América, a solidariedade dos patrícios, a leitura das cartas e as informações recebidas das famílias e amigos sobre a situação social e econômica de Cabo Verde etc.

Eugénio Tavares viaja para o exílio com vários objetivos: fugir à ameaça de prisão pelo governo colonial, trabalhar e estudar os vários aspectos da emigração. Portanto, além de um tema do núcleo ultrarromântico do qual lança mão, o poeta tem motivos contextuais e biográficos que respaldam a exploração mais profunda da questão do afastamento da terra-natal:

\section{Exilado}

Pensa no que há de mais sombrio e triste;

Terás, destes meus dias vaga imagem:

Soturnos céus - como tu nunca viste Nunca os deixou o halo duma miragem.

O sol - um sol que só de nome existe Envolto na algidez e na brumagem Dum frio - como tu nunca sentiste Do nosso sol parece a morta imagem.

Imerge o retranzido pensamento

Nas noites mais escuras, mais glaciais, Prenhes de raios e de vendavais:

Verás que anos de dor, esse momento Passado, na saudade e no penar,

Longe do sol vital do teu olhar.

Fairhaven, 1900 (TPOLP, p. 12, grifos nossos) 
Neste poema, Eugénio conjuga habilmente os ecos dos episódios aubiográficos com o tema da distância amorosa e com a atmosfera soturna que reveste os dias de exílio da ilha de origem. O campo semântico do exílio assim se define: "sombrio e triste", "soturnos céus", "nosso sol parece a morta imagem", "noites mais escuras, mais glaciais,/ Prenhes de raios e de vendavais", "anos de dor", "saudade e penar".

A data da escrita do soneto, 1900, leva-nos a uma triste recordação, por se tratar do ano em que Eugénio Tavares, motivado por perseguições políticas portuguesas, teve que deixar Cabo Verde às escondidas, para morar nos Estados Unidos.

O poema, carregado de nostalgia, incita o leitor a refletir sobre a triste realidade dos que vivem longe de sua terra em dias sombrios marcados pela melancolia, pela saudade e pela solidão em solo estrangeiro, cujo ambiente "soturno" contrasta com os espaços cheios de luz da terra-mãe.

Verifica-se, no soneto, uma correlação entre o estado psíquico do exilado e o ambiente externo da terra de acolhimento.

Também em "Nostalgias, distante da terra natal, o eu lírico aguarda, saudoso, a chegada do "navio da Brava" como se este trouxesse a própria terra, tal a força das notícias e das vivas lembranças nunca esquecidas de quem partiu:

\section{Nostalgias}

\section{Lá vem navio da Brava!}

Ai, lá vem

Roçando as velas de neve,

Brancas de neve ao luar,

Ao de leve

Nas ondas mansas do mar!

Ai! lá vêm novas da Brava

E bênçãos de minha mãe

Que com lágrimas me escreve!

Minha mãe! Vejo-a chorosa,

Triste n'alma,

À soleira, ao fim do dia,

Rezando a sua oração,

Pedindo à Virgem Maria,

Pedindo à Virgem Dolorosa

Lhe traga o filho na palma

Na palma da sua mão!

Vejo-a contando às vizinhas

(Velhinhas tão adoradas

Que são, quase, pelo amor,

Outras tantas mães, Senhor!)

O que as minhas cartas rezam; 
As saudades que padeço;

Os desgostos que em mim pesam

A data do meu regresso!

Vejo-as todas, coitadinhas,

Tão amigas, tão magoadas,

Limpando os olhos leais

Nas pontas dos aventais!

Ai! vejo os entes queridos,

(Longe dos quais não há riso

Que dure nos lábios meus)

Ouvir ler, reunidos,

As cartas que lhes escrevo!

E neste plácido enlevo,

Neste sonho, até diviso

Uma visita chorosa

Que se abeira cautelosa

E murmura, de momento:

- Deus o traga a salvamento!

Ao fundo, enxergo outra Dor:

Manso o gesto e triste o olhar,

Muda a boca dolorosa,

Porque tem a alma do amor,

Vejo a companheira amada

Tão modesta, tão bondosa,

Tão simples, tão adorada

Deixando o pranto cair

No cálice perfumado

De um sorriso amargurado!

Vejo a pérola a fulgir!

No níveo seio da flor!

Grandes lágrimas etéreas

Contai-me as mágoas sidéreas

Dos olhos de onde caístes

Prantos doces, prantos tristes...

Disse-me esta noite a lua

O nenúfar que flutua

No imenso rio dos céus,

Que te viu... que lhe contaste

Tua mágoa...

E que os negros olhos teus

Rasos d'água,

Se baixaram

E choraram

Como flor pendida da haste

Orvalhando a terra nua!

Lua branca! lua triste!

Quando, na volta, passares

Pelo meu saudoso vale,

Lua amiga! se a topares

Dize-lhe que em mim existe

Inda, o mesmo escuro mal 
Terrível como os olhares

Das trevas que se cerram...

Profundos como esses mares

Profundos que nos separam.

Ignotus, Tarrafal de S. Tiago

(TPOLP, pp. 98-100, grifos nossos)

Marcado pela melancolia, o poema, grafado pelo pseudônimo Ignotus, trata-se de um poema ultrarromântico tardio em que avultam características deste momento literário. Dentre elas, destacamos a presença do saudosismo, da natureza, da noite (lua) e a exaltação da terra natal.

A linguagem teatral (visualizamos cenas da Brava), plena de exclamativas enfáticas, diminutivos (“coitadinhas”), repetições, de escolha vocabular requintada ("plácido enlevo", "níveo", "etérea", "sidérea", "nenúfar") alia-se à tristeza e à religiosidade, culminando no ambiente terrífico da última estrofe para traçar a ambientação soturna do emigrante que anseia por regressar ao aconchego do lar, dos braços da mãe e dos entes queridos.

Se a partida traz a dor da despedida e a nostalgia do ninho amado, o retorno, por sua vez, traz de volta a alegria adormecida:

Vasco Martins, a propósito do tema, esclarece:

Cabo Verde, país de emigração maciça, país de ilhas e de Oceano, possui na sua alma a mitologia da partida que tem sempre um regresso ou pelo menos a idéia do regresso. A saudade é um sentimento que acompanha a partida, uma saudade romanceada, por vezes profunda e pondo em causa a Terra longe, onde se vai buscar um melhor modo de vida ou, simplesmente, a necessidade de ver o mundo, sair das ilhas para um encontro com outras culturas, outros modos de vida, outras mentalidades (MARTINS, 1989, p. 89).

A díade partida/regresso funciona como mote do soneto

\section{Regresso}

Tanto magoa a triste despedida

Se do lar nos afasta a mão da sorte,

Quanto nos recontenta $\mathbf{o}$ gozo forte

De um regresso à Pátria estremecida;

Se, toda, nos deslumbra a luz da vida, Suave, nos consola o olhar da morte; $\mathrm{Eu}$, tanto adoro uma imutável morte Quanto odeio a miragem fementida. 
Na placidez dos justos, ao morrer, $\mathrm{Eu}$ vejo uma alegria de regresso,

Sinto um repouso de repatriados.

Mas na vozinha triste, amargurada,

Das crianças que choram ao nascer,

Sinto a dor dos que aportam degredados.

(TPOLP, p. 22, grifos nossos)

O poema "Regresso", exemplo acabado do "terra-longismo" como proposto por Manuel Ferreira (1972), já em sua primeira estrofe, em estrutura oximorística, supõe na partida a possibilidade do regresso: "Tanto magoa a triste despedida"/ [...] Quanto nos recontenta o gozo forte/ De um regresso".

O texto apresenta a marca da estrutura do soneto camoniano, ao trabalhar com a fusão dos opostos: "morte e vida", "odeio e adoro" e "gozo forte e sorte", já que a tristeza da partida não exclui a alegria e o repouso do regresso.

No entanto, o último terceto do poema parece sugerir que o destino - "Se do lar nos afasta a mão da sorte" - terá continuidade nas próximas gerações: "crianças que choram ao nascer", por já carregarem consigo a "dor dos que aportam degredados" em estado de exílio, fora do lar “pátrio". Vasco Martins, a esse respeito, acrescenta:

o regresso à terra reveste-se de um certo sofrimento que já se disse habitual na alma cabo-verdiana. Sem a saudade ou o sofrimento [...] o regresso seria normal, pouco romântico, pouco sentido. Por vezes, a alma cabo-verdiana esconde-se numa jovialidade e alegria de viver que esconde, no entanto, essa intensa melancolia provinda de 500 anos de história da agressividade da terra, do mito da partida para terras longínquas (MARTINS, 1989, p. 95).

No poema "Triste Regresso", o eu lírico comove-se ao voltar à sua ilha em meio a uma grande estiagem:

Triste Regresso

Dentro da claridade plúmbea da manhã A Ilha, sobre o mar, lembra uma catedral. As nuvens em silêncio imergem devagar

Qual um fumear de incenso

Num ascetismo intenso,

Num perfume subtil de velha fé cristã,

Pelas naves glaciais da brônzea catedral,

A ilha, sobre o mar. 
E sobem vagamente em lágrimas banhando A dura fronte augusta e grave dos rochedos. Bebe em fundo silêncio a terra fulva, adusta, A lágrima que cai;

E a nuvem passa, vai,

Numa insondável mágoa imensa rorejando, Em gélido suor, dos túrbidos rochedos

A dura fronte augusta.

Mas, já da opa cinzenta a Ilha se desnuda,

Beija-a com fúria o sol, dentes de fogo a comem

$\mathrm{O}$ vento reduziu-lhe a trapos o lençol.

Emerge, se acentua,

Do mar, imóvel, nua,

Transida de tristeza, em uma angústia muda...

E enquanto ao longe as nuvens álgidas se somem

Beija-a com fúria o sol.

Da c'roa do platô à fímbria da leveza

As árvores sem vida estorcem-se de sede

E o sol - bem como um rei fanático, homicida, -

Fustiga-as a matar.

E ri-se ao incendiar

Os ramos - como mãos erguidas de quem reza -

$\mathrm{E}$ as folhas - como mãos abertas de quem pede -

Das árvores sem vida.

Enfim, o meu Navio, aos poucos, se aproxima.

Nos tristes olhos meus em lágrimas, rebrilha

A dita de ancorar após mil escarcéus.

E, pois que as nuvens vão

Fugindo na amplidão

Sem que uma gota de água enviem lá de cima,

Darei à tua sede o pranto - ó minha Ilha! -

Dos tristes olhos meus.

Brava, 1900 (TPOLP, p. 75)

Envolto por uma atmosfera de adoração religiosa, o poema descreve o aparecimento da ilha natal àquele que dela estava afastado, num movimento contrário e complementar ao poema "Partindo", que encenava o abandono do Lar:

Triste, por te deixar, de manhãzinha Desci ao porto. E logo, asas ao vento, Fomos singrando, sob um céu cinzento, Como, num ar de chuva, uma andorinha.

Olhos na Ilha eu vi, amiga minha, A pouco e pouco, num decrescimento, Fugir o Lar, perder-se num momento A montanha em que o nosso amor se aninha.

(TPOLP, p. 11, grifos nossos) 
No poema em tela, ao contrário,

o meu Navio, aos poucos, se aproxima.

Nos tristes olhos meus em lágrimas, rebrilha

A dita de ancorar após mil escarcéus.

(TPOLP, p. 75, grifos nossos)

"Bai é maguado", lembramos a morna mais emblemática de Nhô Eugénio (Hora di bai), triste vai o eu poemático no navio que singra em "Partindo". Dor de amor e dor de saudade. Mas voltar e constatar o sofrimento por que passam os irmãos, no poema "Triste regresso", dá outro significado às lágrimas. Estas serão comparadas à chuva que vai molhar a terra seca:

E, pois que as nuvens vão

Fugindo na amplidão

Sem que uma gota de água enviem lá de cima, Darei à tua sede o pranto - ó minha Ilha! -

Dos tristes olhos meus.

(Ibidem)

O primeiro verso já revela um oximoro, "Dentro da claridade plúmbea da manhã", sugerindo que o regresso não é totalmente livre de obstáculos.

A ilha surge ao sujeito do poema como uma aparição da deusa Vênus, emergindo do mar, vestida pelas nuvens, beijada pelo Sol. O poema é marcado pelo aspecto visual e pelo movimento. Do ponto de vista da geologia, as ilhas de Cabo Verde emergem de uma erupção vulcânica na plataforma submarina e o eu lírico de "Triste regresso" compara o surgimento da ilha Brava, de relevo extremamente escarpado, a uma catedral: "A Ilha, sobre o mar, lembra uma catedral", envolta em nuvens qual "perfume" do "fumear de incenso".

No terceiro verso do poema, "As nuvens em silêncio imergem devagar", verificamos um movimento oposto à gravidade: as nuvens baixam enquanto a ilha sobe, tornando-se ainda mais alta, soberana. Qual Vênus no seu nascimento, "a Ilha se desnuda,/ Emerge, se acentua,/ Do mar, imóvel, nua".

Para quem conhece o contexto das ilhas e considerando que o poema retrata uma cena das estiagens frequentes no arquipélago, a nudez pode ser associada à aridez da paisagem cabo-verdiana, batida pelo sol e pelo vento inclemente: "Beija-a com fúria o sol, dentes de fogo a comem/ O vento reduziu-lhe a trapos o lençol”. 
Desta forma, o mito de Vênus, é contextualizado de modo a expressar o amor e a beleza que o poeta devora à sua pátria-ilha.

Verifica-se todo um movimento gradativo no poema, em que esta ilha-mulher é revelada primeiramente pela tristeza e angústia do semblante (o seu sofrimento pela seca) e, mais adiante, na nudez de corpo inteiro:

Mas, já da opa cinzenta a Ilha se desnuda,

Beija-a com fúria o sol, dentes de fogo a comem

$\mathrm{O}$ vento reduziu-lhe a trapos o lençol.

Emerge, se acentua,

Do mar, imóvel, nua,

Transida de tristeza, em uma angústia muda...

(Ibidem)

Ao mesmo tempo, suas lágrimas de tristeza funcionam como estratégia de sedução, como n'Os Lusíadas, de Camões, na cena em que Vênus chora, nua, diante de Júpiter (Canto II, estâncias 36 a 42), para convencê-lo a favorecer a viagem dos portugueses. Como resultado, "enquanto ao longe as nuvens álgidas se somem / Beija-a com fúria o sol".

Em consequência desta erotização da aparição da ilha, nos versos seguintes: "As árvores sem vida estorcem-se de sede/ E o sol - bem como um rei fanático, homicida, -/ Fustiga-as a matar"/ "E ri-se a incendiar", em extremo gozo.

$\mathrm{Na}$ última estrofe, sem a mínima possibilidade de chuva - "E, pois que as nuvens vão/ Fugindo na amplidão/ Sem que uma gota de água enviem lá de cima" -, o regresso gradativo ("o meu Navio, aos poucos, se aproxima”) do eu lírico, provavelmente distante da Ilha por longo tempo e/ou com grandes dificuldades para regressar à terra natal (hipóteses sugeridas pelo advérbio “enfim”) reveste-se de tristeza.

“Ancorar" ou "fincar os pés na terra", lema dos claridosos, significava resistir e ficar na ilha, nem que à custa de regá-la com as lágrimas: "Darei à tua sede o pranto - ó minha ilha! -/ Dos tristes olhos meus".

A fusão alegórica do eu lírico com a ilha expressa-se como um conluio amoroso, de um amor extremo à terra natal, comparável ao que o intelectual Eugénio Tavares dedicava a Cabo Verde ${ }^{19}$.

\footnotetext{
${ }^{19}$ Esta leitura do poema "Triste regresso" está ancorada em hipóteses levantadas pela pesquisa da Profa. Doutora Simone Caputo Gomes, "Metamorfoses de Vênus: formação e desenvolvimento da série literária caboverdiana", Universidade de S. Paulo.
} 
Os poemas "Quando, depois da viagem tormentosa" e "Minha casa" complementam este micronúcleo do regresso ao lar, unindo lirismo amoroso, telurismo e sonho numa proposta de evocação da "casa" cabo-verdiana:

Quando, depois da viagem tormentosa

Cheguei, enfim, a porto e salvamento,

Quando, cansado, adormeceu o vento

E serenou a fúria procelosa;

Quando rompeu essa manhã radiosa

Do meu regresso ao lar, e que um momento

Senti amortecer-se o sofrimento

Numa tranquiila trégua deliciosa;

Quando, de manhãzinha, despertando,

Te vi junto de mim, num repousar

De anjo, pensei: - Estarei eu sonhando?

Mas quando abriste os olhos, devagar,

Então roguei-te, manso, soluçando:

- Não me despertes! Deixa-me sonhar!

(TPOLP, p. 22, grifos nossos)

Os braços da amada são porto e casa onde se refugia o eu poemático. Tornam a

"manhã radiosa" e transformam o "sofrimento" em "trégua deliciosa".

\section{Minha Casa}

\section{A Duarte Silva}

Ó minha pobre casa! estância honesta!

Minha felicidade inigualada!

Quem me dera passar, nesta jornada,

Â tua sombra, a vida que me resta!

Tudo me fere, tudo me molesta

Longe de ti, ó minha pobre amada!

O sol mais claro não me alegra; nada

Me aquece e me ilumina a fronte mesta!

O meu destino, túrbido, mesquinho,

Na saudade dos olhos siderais

Da companheira que ficou no ninho,

Arrasta-me a visões de dor, mortais:

E penso que talvez neste caminho

Não paro à tua sombra nunca mais!

(TPOLP, p. 12, grifos nossos) 
Longe do "ninho" amado (e da mulher amada), "tudo fere, tudo molesta", o trajeto é definido como "viagem tormentosa" sob "fúria procelosa" e o "destino", "túrbido, mesquinho".

A soturnidade e o pessimismo ultrarromântico expressam-se enfaticamente por meio de dois sentimentos: saudade e dor.

\section{Saudade}

O muito amor por teus olhos quebrados

De sofrer; esta cruel adoração

Por ti, que me trespassa o coração

Nas puas da saudade e dos cuidados;

Estes males da ausência inconsolados,

Deram-me a crença da superstição:

E sigo a incerta fé do povo vão,

Interpretando sonhos enublados...

E lhes pergunto, às vezes, se és feliz...

Se ainda te animam esperanças calmas...

E me sorrio sempre que sorris.

Porque amarrados ambos numa cruz,

Embora separados, nossas almas

Formam uma só vida, uma só luz.

(TPOLP, p. 14)

Em síntese, esse núcleo que tematiza o "terra-longismo" cabo-verdiano e, ao mesmo tempo, o exílio de raiz ultrarromântica, expressará os sentimentos gerados pelas vivências de afastamento, tanto do arquipélago quanto da mulher como representante da terra-mãe ou do aconchego amado.

Para Luís Silva,

Não é possível fazer uma leitura de Cabo Verde sem passar pela literatura, marcada por muitos exílios, dentro das ilhas, no espaço colonial e nos países da emigração. Falar do exílio na literatura caboverdiana obriga-nos a repensar o isolamento e as condições geográficas que limitam os passos de cada indivíduo (2006, p. 24).

Para encerrar este item, cabe ainda ressaltar o tema da emigração forçada para

S. Tomé e Príncipe, retratada em poema do pseudônimo Orion.

Sobre as formas de emigração, António Carreira (1984) destaca a espontânea e a forçada, a que o poema de Eugénio Tavares aqui enfatiza: 
Forçada, ou seja, segundo nossa opinião, toda a que se processa em consequiência da ruptura do equilíbrio produção/população, ruptura essa provocada por secas, fomes, mortandades ou pressão demográfica e de que os governos se aproveitaram para incentivar e encaminhar, por meio de medidas legislativas ou processos administrativos, a saída da população com o objetivo deliberado de proporcionar mão-de-obra abundante e a baixo salário às organizações agrícolas e industriais de tipo capitalista da região tropical ou equatorial. É o caso concreto de S. Tomé e Príncipe (CARREIRA, 1984, p. 162).

Acompanhemos o poema:

\section{A Emigração}

(A propósito da emigração para S. Tomé e Príncipe)

Como é triste e é desolador, Ver partir, aos magotes, esta gente, Entregue ao seu destino, indiferente A tanto sofrimento, tanta dor!

Se a sorte ainda a traz à terra amiga, Macilenta, tristonha, depaup'rada, Com a doença do sono, já minada, Ao cemitério um só coval mendiga!

Mas porque ides, assim arrebanhada, A essa maldita terra de desterro? É a fome que vos leva acorrentada?

Aproveitai melhor a mocidade E ide mais distante, ide à América A terra do trabalho e liberdade!

Orion (TPOLP, p. 38, grifos nossos)

O soneto acima parece duplicar no subtítulo explicativo a marca do sofrimento de quem parte para as ilhas "de desterro": "A propósito da emigração para S. Tomé e Príncipe”. Neste sentido, o eu lírico quer chamar a atenção para o malogro que era partir para aquela colônia portuguesa, sede do trabalho "contratado", do qual a maioria dos cabo-verdianos, iludidos por promessas de sobrevivência e melhoria da qualidade de vida, para fugir às secas frequentes e suas consequências, muitas vezes não retornavam por morte ou retornavam para tratamento de saúde.

O primeiro quarteto revela que partir para São Tomé e Príncipe não é algo alentador. O eu poemático enfatiza - "Como é triste e é desolador/ Ver partir aos magotes, esta gente" -, revelando um estado precário tanto em Cabo Verde quanto no distante arquipélago produtor de café e cacau. 
Novamente vemos neste poema o trabalho de Eugénio Tavares com o binômio partida/regresso. No entanto, no soneto "Emigração", o retorno pode significar a morte:

Se a sorte ainda a traz à terra amiga,

Macilenta, tristonha, depaup'rada,

Com a doença do sono, já minada,

Ao cemitério um só coval mendiga!

$\mathrm{Na}$ época do contrato, geralmente, quem conseguia voltar para Cabo Verde, retornava em estado de penúria pior de que a da partida ou com doenças como a malária ou a tuberculose. Desta forma, o retorno de São Tomé e Príncipe não condizia com o de outros emigrantes que voltavam, principalmente, dos Estados Unidos da América, trazendo consigo recursos financeiros significativos para o arquipélago. Por isso, o poeta sugere ao receptor-modelo do texto, provavelmente cabo-verdiano, que, em caso de necessidade, emigre para os Estados Unidos, onde poderá viver melhores dias na "terra do trabalho e liberdade".

Nos dois tercetos, enfatiza-se que os emigrantes partem para São Tomé e Príncipe "aos magotes", "arrebanhados" em consequência de uma política colonial que não se interessava pelo bem-estar da população crioula, mas por sua força de trabalho nas ilhas "da sujeição".

Sobre esta estratégia do governo colonial e como ela é percebida pelos caboverdianos, ressalta ainda António Carreira:

A ida do cabo-verdeano para as roças de S. Tomé e Príncipe foi sempre considerada no arquipélago como uma deportação ou mais propriamente uma condenação a degredo - sem se ter cometido crime algum. Tanto assim que não se dizia que alguém embarcou para $S$. Tomé, mas que "embarcou para o Sul", alusão ao envio de condenados de delitos comuns pelos Tribunais ordinários para Angola, onde iam cumprir penas - como era então corrente. Por outro lado no consenso geral o "dar o nome" ao agente recrutador para a efectivação do contrato de trabalho para $\mathrm{S}$. Tomé, correspondia a uma auto-condenação. Todos os indivíduos que se contratavam para o Sul faziam-no atemorizados e pressionados pelas conseqüências das estiagens ou quando se declarava o "estado de crise". O contrato para o Sul era o último recurso a lançar mão, uma vez reconhecida a impossibilidade de emigrar para qualquer outro país. Não era apenas o horror ao clima ou à dureza do trabalho nas roças. Era a certeza de não se amealhar um pecúlio que justificasse o esforço despendido. $\mathrm{O}$ salário era extremamente baixo, a alimentação nada condizente com os hábitos do cabo-verdeano, e o tratamento mau (1984, p. 175). 
Diante das calamidades vividas no arquipélago em períodos de longas estiagens, causadoras de miséria, fome e migrações, muitos não encontravam outra saída a não ser aceitar o "regime de contrato" para trabalhar nas roças de São Tomé e Príncipe em troca de um salário de fome, contraindo dívidas que nunca conseguiriam saldar. A menção do termo "arrebanhada", no nono verso do soneto, pode ser considerada ousada para a época e um enfrentamento de Eugénio Tavares ao governo português. Por este motivo, o poeta muitas vezes fazia uso de pseudônimos, como Orion, P. Direito, Ignotus, Tambor-mor, Jon di Mamai, Sysipho, entre outros.

João Lopes Filho, no que toca ao dilema entre emigrar e partir, esclarece:

\begin{abstract}
Atormentado, principalmente pelas secas, impeditivas da prática agrícola (o seu meio de subsistência fundamental), o cabo-verdiano "embarca" na aventura da emigração, passando esta a significar (mais do que a realização de um sonho) uma forma de sobrevivência. Apesar de tudo, o cabo-verdiano prefere continuar no contexto sociocultural a que está habituado, em vez de enfrentar o desconhecido da terra-longe (2007, p. 28).
\end{abstract}

No caso específico de Eugénio Tavares, o terra-longismo pode ser definido conforme a proposição de Gabriel Mariano:

Em Eugénio Tavares, a contradição entre o querer ficar e o ter de partir é superada pela idéia de que o essencial é adquirir a experiência do regresso (isto é: da ressurreição), sendo que, para ganhar a experiência do regresso, a partida (isto é: a morte) é o meio e a condição indispensáveis. Aceita-se e atenua-se o sofrimento da partida (isto é: da morte), porque sem ela não se atinge o fim almejado: a ressurreição (isto é: o regresso).

Em Eugénio, a partida busca o tempo futuro; o tempo posterior à morte, o tempo da ressurreição (1991, p. 138).

\title{
2.3 - O núcleo da problemática social cabo-verdiana e as estratégias de abordagem
}

esperamos

a solução urgente

dos nossos problemas

dos nossos dilemas

Jorge Barbosa

Não poderíamos deixar de mencionar que, na produção em língua portuguesa, Eugénio Tavares desenvolve a sua veia político-social, como na produção em prosa, especialmente no jornalismo. Além disso, vem à tona, em uma série de poemas, um 
Eugénio Tavares satírico, que vai usar da poesia para criticar a sociedade da época, expor as mazelas vividas pelo povo cabo-verdiano sob o jugo colonial e reivindicar melhorias junto às autoridades governamentais. Para a realização desse tipo de poesia, em que a crítica social aparece mais deliberadamente, por meio de estratégias como a denúncia e o humor, o poeta adota o uso de pseudônimos.

No poema "A tarde", o espaço geográfico cabo-verdiano começa a apresentar o cenário das exposições críticas de Nhô Eugénio:
A tarde, melancólica, nevoenta, Duma tristeza mansa, resignada, Volta a banhar a terra amarelada, Volta a azular a serra lenta e lenta.
A névoa infiltra-se, húmida, cinzenta, No peito dos que sofrem, como espada Que o vento - o espírito de mão gelada - Desfere pela tarde pardacenta.
E o vento passa lamentosamente, Passa ferindo o ar, cortando rente As ilusões das almas sem ventura.
E as névoas semelhantes a mortalhas Envolvem a minha alma em suas malhas, Dentro da tarde feita sepultura.

(TPOLP, p. 25, grifos nossos)

A aridez ("terra amarelada", "tarde pardacenta") e o "vento [...] ferindo o ar" evocam a paisagem semidesértica das ilhas, à qual o ultrarromantismo adiciona a melancolia, a tristeza, o sofrimento anônimo, a desventura, com uma carga de dramaticida degradativa que desemboca na "mortalha" e na "sepultura".

O contexto colonial cabo-verdiano das grandes e frequentes secas (documentadas por António Carreira desde o achamento das ilhas), agravado pela incúria do governo luso, constitui o subtexto que opera a interlocução do poema.

António Carreira (1984), ao referir as crises de 1903-4, 1916-18, 1921-22, 1923-24, 1941-43, 1947-48, argumenta:

A pobreza natural das ilhas, todas elas dependentes de uma economia agrícola com fraco suporte na criação de gado, agravada pela persistente irregularidade das chuvas quando não por prolongadas estiagens (umas com a duração de cinco anos, outras com a de dez e 
mais), sujeita o cabo-verdeano a condições de vida extremamente duras e difíceis (p. 159).

A poética de Eugénio Tavares, antecipando a saga dos Flagelados do Vento Leste, tão fértil em textos literários em Cabo Verde, assim qualifica o povo crioulo:

\section{Os Miseráveis}

A Adriano de Faria

Trazei, ó pobres Mães esfarrapadas, Ó Mães de emagrecidos, murchos seios, Trazei à minha dor, aos meus anseios, As vossas falas pálidas, veladas.

Ponde na minha fronte as mãos geladas, Nos olhos meus, os vossos olhos cheios De tristeza! voarão aos vãos receios Como bando de corujas assustadas.

Os infelizes devem caminhar De mãos unidas; pela noite em fora, Uns aos outros se devem amparar:

O mal que nos esmaga e nos dessora, Se a um só despedaça sem demora, A muitos é mais leve de arrastar.

$$
\text { (TPOLP, p. 34). }
$$

As Mães, maiúsculas representantes da terra cabo-verdiana, apresentam-se "esfarrapadas", com "murchos seios" que não alimentam os filhos "emagrecidos", semimortas ("mãos geladas"), habitando um cenário lúgubre e noturno de "tristeza", "dor" e "corujas assustadas", no melhor do estilo ultrarromântico.

O apelo católico à Nossa Senhora das Dores (também Mãe), denominada Nossa Senhora d'Outubro porque este é o mês das chuvas em Cabo Verde, caberia com justeza num contexto de estiagem e fome na "terra nua e fulva" do "vento leste":

\section{Nossa Senhora d'Outubro}

(Ao meu amigo o ex ${ }^{\mathrm{mo}}$. e rev ${ }^{\mathrm{mo}}$. Cónego André Firmino)

Ó Nossa Senhora do bom mês d'Outubro!

Eu me ajoelho ao pé do vosso altar de Dores

Bem como ante esse outro, que cobris de flores, Na montanha azul, eu me curvo e descubro. 
Hoje faz um ano, que na vossa festa Andavam bem tristes tantos corações! Quem te visse, ó terra, nua, fulva e mesta, Qual sentisse mágoas n'alma e aflições.

A fome assentava-se nos lares frios; Ceifava Esperanças pelo prado a peste; Incendiando a seara o ígneo vento leste No futuro, abria boqueirões sombrios.

Mas faz hoje um ano, ó celestial Senhora, Não faltaram flores, nem fiéis, nem cantos; Então, quantos tristes ocultavam prantos! Quanta noite negra feita rósea aurora!

Mas havia fome, mas havia estiagem, Requeimando o leito verde das ribeiras; Estava frio, morto, o fogo das lareiras; A pedir mais graça: mais pia a romagem.

Este ano que há flores, tantas pelos prados, Eu não vejo lírios no altar da Senhora! Foi-se a noite feia, vem rompendo a aurora; Por sobre campos por Deus abençoados.

Vão-se os sonhos negros, vão-se escorraçados; Mas hoje na vossa igreja não descubro Alegrias, flores, fiéis ajoelhados, Rendendo-vos graças, Senhora d'Outubro!

(TPOLP, pp. 77-78, grifos nossos)

Contudo, neste poema, o eu lírico adverte os compatriotas, pois que, neste ano de chuvas ou azáguas ("Este ano que há flores, tantas pelos prados"), o cabo-verdiano esqueceu de homenagear a santa. Só o faz, como há um ano atrás, quando a chuva não vem: "Mas hoje na vossa igreja não descubro/ Alegrias, flores, fiéis ajoelhados,/ Rendendo-vos graças, Senhora d'Outubro!"

Além da problemática econômica e social relacionada à seca, Eugénio Tavares denuncia o descaso das autoridades coloniais com elementos indispensáveis da infraestrutura do cotidiano das populações, que afetam a sua qualidade de vida. Reportermonos ao capítulo 1, em que, em textos de intervenção (em prosa), Eugénio trata com veemência o assunto e interpela as autoridades, propondo a exploração de nascentes, sistemas de irrigação e arborização: "Não entraram inda V. Exas. Na convicção de que a calamidade pública da fome deve ser atacada nas suas causas? (TVTCP, p. 275).

O fornecimento de energia e de saneamento básico são também temas frequentes dos poemas eugenianos em língua portuguesa, como se estes constituíssem 
peças de denúncia endereçadas diretamente aos administradores, que entendiam plenamente a língua lusa, não dominada pela maioria da população crioula.

\section{Luz e Flores}

$\mathrm{O}$ aroma das flores, sua fragrância e a luz a realçar-lhe as belas cores, casam-se como o idílio d'amores; alegram os adultos e a infância.

\section{A nova comissão municipal, promete-nos mais luz e uns jardins, com um quiosque envolto por jardins, na praça da cidade, a principal.}

Mas para que tal melhoramento, os benefícios possam resultar, é preciso fazer encanamento,

de matérias um tanto mal cheirosas qu'espalhadas de noite pelo ar, não se ligam à fragrância das rosas.

Orion (TPOLP, p. 39, grifos nossos)

A linguagem poética e romântica da primeira estrofe, em contraste com o discurso referencial-informativo das duas seguintes, evidencia a proposta irônica do poeta, que cobra das autoridades as providências necessárias prometidas. O último terceto do soneto, desmentindo a proposta da primeira quadra, evidencia o desleixo do colonizador com relação à situação do arquipélago.

No poema seguinte, o tema se aprofunda:

O mistifório ou, por outra, a mistura

de líquidos - gases heterogêneos, é igual à junção de dois maus génios, e por isso, em geral, se não atura.

Os mui dignos senhores vereadores, acabado o contrato com a lua, experimentam iluminar a rua, com lamparinas, mas de duas cores.

O petróleo de cor amarelada, com o azul que dá o carboreto, não se casam nem juntam mesmo nada.

Ou bem que fique só o petroline, ou haja somente o acetilene, mas coisa que se veja, ilumine! 
A iluminação e o sistema de esgoto continuam na pauta da pena virulenta de Nhô Tatai (Eugénio), e o humor é a estratégia escolhida para a crítica: os "gases heterogêneos" rimam com "maus gênios" e os vereadores se dignam a experimentar, ao invés de resolver os problemas. No último terceto, enfático e exclamativo, podemos resgatar a indignação do intelectual frente à situação apresentada.

O poema a seguir descreve o auge do descaso e a ausência de amparo que a população pode esperar dos governantes:

\section{Já não temos mais para onde apelar, agora completou-se a escuridão! \\ Não há vestígio d'iluminação, \\ a não ser um ténue raio de luar. \\ Eu estoiro numa forte gargalhada! \\ Acabou-se até mesmo o carboreto! \\ Já para nada serve um bom soneto, temos de lançar mão duma espingarda;}

ou então visto a lua andar mais clara, parece-me seria mais sumário, atirar-lhe quatro ganchos à cara,

quando ela vai a encher no outro mês, suprimir-se-lhe um quarto ao calendário e ficar assim cheia duma vez!

Orion (TPOLP, p. 41, grifos nossos)

A lua, um signo romântico, e o soneto, forma poética consagrada, funcionam aqui como base para a sátira de Eugénio à problemática da iluminação pública, não resolvida. A resistência já se configura no verso "temos de lançar mão duma espingarda". Ridendo castigat mores, ridendo dicere severum ${ }^{20}$. Por meio do humor, Eugénio Tavares demonstra sua insatisfação com o governo colonial e cobra soluções.

$\mathrm{Na}$ linha deste poema, Eugénio ainda presenteia o leitor com outro soneto em que a retórica poética romântica dará suporte a uma abordagem humorística de temas do cotidiano das ilhas:

Há tempos onde se venera a luz, povos que o sol, o astro-rei, namoram; avezinhas o claro dia adoram, se o céu espalha claridade a flux!

\footnotetext{
${ }^{20}$ Com o riso castigam-se os costumes, com o riso diz-se coisas sérias.
} 


\section{A abelha zumbe quando nasce o sol; a mariposa gira com amor, em espiral por sobre o caule da flor, mal aparece além o arrebol.}

Se pois a luz a tudo alegra e encanta, desde o homem até ao animal, desde pequeno insecto até à planta,

\section{porque é - perguntaremos nós então - que a nossa comissão municipal nos dá aqui tão negra escuridão?}

Orion (TPOLP, p. 42, grifos nossos)

O diminutivo ("avezinhas"), os chavões lírico-amorosos ("a mariposa gira com amor",/ em espiral por sobre o caule da flor", "a abelha zumbe quando nasce o sol”), o vocabulário erudito ("flux”, “arrebol”), são elementos ultrarrromânticos aqui manipulados, nas três primeiras estrofes, para provocar o choque do leitor com o último terceto, de denúncia da incúria da comissão municipal. O artifício, extremamente moderno, é utilizado, por exemplo, por Manuel Bandeira no poema "Satélite", em que descontextualiza (ou "desconsteliza"21, como designação de Haroldo de Campos) o astro romântico e joga-o para o campo do cotidiano referencial.

Seguindo a mesma estratégia de ironizar os tópicos românticos, o poeta retoma o último terceto do poema anterior e, num metapoema, promete disparar uma série de sonetos sobre o tema em pauta (a iluminação pública), em tom de ameaça:

\section{Com vista à comissão municipal se a lua, bela luz já não espalha, por não ter combustível na fornalha, e não poder remediar o mal; -}

Se o novo acetilene envelheceu e nos dá fraca luz com estampidos, de rebentar o sangue dos ouvidos; se tudo pois assim ensandeceu; -

manda-se, desde já, à fava a lua; acabe-se de vez o carboreto, e seja também mandado à tábua;

\footnotetext{
${ }^{21}$ BANDEIRA, Manuel (1963), p. 6. Poema "Satélite": Fim de tarde./ No céu plúmbeo/ A Lua baça/Paira/Muito cosmograficamente/ Satélite.// Desmetaforizada,/ Desmitificada,/ Despojada do velho segredo de melancolia,/ Não é agora o golfão de cismas,/ O astro dos loucos e dos enamorados./ Mas tãosomente/Satélite.// Ah Lua deste fim de tarde,/ Demissionária de atribuições românticas,/ Sem show para as disponibilidades sentimentais!// Fatigado de mais-valia,/ Gosto de ti assim:/ Coisa em si,/ - Satélite. Conferir ainda CAMPOS, Haroldo. "Bandeira, o desconstelizador". In: Metalinguagem, 1967, p. 102.
} 


\section{venha o petróleo em lampiões d'espeto \\ para sem uma luz ficar a rua, \\ senão ainda prometo outro soneto.}

Orion (TPOLP, p. 41, grifos nossos)

A lua, astro protetor dos amantes, é mandada "à fava", juntamente com os novos materiais usados para iluminação - o acetileno, que "envelheceu", e o "carboreto [...] mandado à tábua"; de acordo com a lógica "ensandecida" constatada no espaço da colônia pelo eu lírico, a solução é inverter o tempo e voltar ao antigo método: os lampiões de petróleo.

Por fim, cansado de exigir soluções para os mesmos problemas, o poeta resolve conceder-se uma pausa para aproveitar a luz natural da lua e também o período de carnaval. Na verdade, Eugénio Tavares opera uma carnavalização, lembrando Bakhtin, de um tema social e infraestrutural sério, assim como insere o astro tão caro aos ambientes românticos num espaço dionisíaco (Baco).

Um compasso de espera não faz mal!

Não falemos em luz esta semana, Que tempo sobrará para a pavana! Queremos também descanso semanal!

E depois estes dias a lua tem dado bela luz e tão brilhante, que nos faz esquecer, por um instante as trevas em que anda sempre a rua.

Fazemos por aqui ponto final, e para assunto algo intrigado, visto estar a entrar o carnaval, pedimos um cantinho reservado, no próximo número do jornal, para soneto mais ponderado.

Orion (TPOLP, p. 42, grifos nossos)

O último terceto, metapoético, mas irônico, permite-nos constatar a modernidade das estratégias empregadas, no início do século XX, por Eugénio Tavares, como já o assinalávamos a respeito da semelhança com o artifício bandeiriano da desconstelização.

O poema "Pelo Carnaval" parece complementar o anterior, tanto no tema, o Carnaval, quanto na linguagem humorística e dionisíaca ("vassouras, um bidé 
escangalhado [...] gases d'algum vaso reservado" e intenção metapoética (“Aí tendes, em verso pé-quebrado,/ soneto feito todo aos trambolhões!":

Ressalte-se que o Carnaval de Cabo Verde, sobretudo o da ilha de S. Vicente, dialoga com o carnaval brasileiro, que toma por modelo.

\section{Pelo Carnaval}

Pó de arroz, dominós e serpentinas, Cocotes, rebuçados e besouros, Estalos, estalinhos e estouros, Chapéus e capacetes, barretinas;

repolhos com bugalhos e nabiças, leques, lenços, abanos, abanicos; craveiros, malmequeres e manjericos, escravelhos e cordas com adriças;

vassouras, um bidé escangalhado, baldes, com frigideiras, caldeirões, gases d'algum vaso reservado;

pevides, melancias e melões! Aí tendes, em verso pé-quebrado, soneto feito todo aos trambolhões!

Orion (TPOLP, p. 40)

Ainda na linha da crítica aos problemas urbanos, como iluminação e saneamento, Eugénio chega a satirizar até o funcionamento do relógio municipal:

\section{O Relógio Oficial}

Foi atacado de dispepsia

o velho relógio municipal.

A doença, porém, não é mortal, mas vai recolher à enfermaria.

Não funcionava bem o mecanismo por ter já alguns dentes estragados, para salvar de todo o mecanismo.

O mal não há-de ser de muita dura, e visto termos cá tanto dentista algum lhe mudará a dentadura.

E depois o relógio, já curado, passa a dar-nos a hora, bem prevista, luzidio, limpinho, envernizado!

Orion (TPOLP, p. 38) 
O soneto, forma fixa geralmente utilizada para abordar assuntos graves ou do campo filosófico, na obra poética de Eugénio Tavares serve a propósitos outros, sob o signo de uma carnavalização que pretende demonstrar todo o desleixo das autoridades em relação a problemas do cotidiano em Cabo Verde. De forma bem humorada, o poeta trabalha com o termo "dentes estragados" em diversos sentidos, aludindo ainda a questões de saúde pública: os dentes do relógio, por estarem estragados, atrapalham o funcionamento da máquina "oficial", que aqui pode representar o governo português/a administração da colônia.

Observa-se também que os "dentes estragados" causam dispepsia, ou seja, difículdade de digerir o "desgoverno" luso, que não resolve os problemas (“dentes estragados") do arquipélago, que poderiam ser solucionados pelos próprios caboverdianos ("visto termos cá tanto dentista").

Por ser um instrumento complexo de precisão, em que cada parte deve funcionar em sintonia, o sistema está "doente" ("Não funcionava bem o mecanismo"), porque, em virtude da distância do governo metropolitano e do descaso, aquela não acontece em teros de infraestrutura do arquipélago. Neste sentido, o poeta, de forma sarcástica, pinça uma situação que parece insignificante para satirizar, em conjunto co outras ocorrências, a inépcia dos responsáveis, a nível macro, pelas possíveis soluções para a viabilidade da qualidade de vida nas ilhas.

Tomando o mote da "doença" em outro soneto, Eugénio criticará, por meio da inversão de argumentos, uma tese bastante discutida em Cabo Verde, na época de sua escritura, sobre a indolência do homem crioulo, dado aos exageros do grogue:

À mesa, um dia, estavam dois doutores (desses que curam doenças, as piores, Co'a vida o sofrimento arrefecendo) sobre matérias graves discorrendo:

Tratava, um, de provar que os bebedores crioulos, (brancos nunca!) iam perdendo a mioleira, em virtude dos calores que a pinga neles vai desenvolvendo...

- Homem, não digas isso! - replicava o outro doutor ardendo em fúria brava, se toda essa manada de crioulos desprovida estivesse de miolos quem nos fabricaria, hoje, essa cana que divina parece mais que humana?

Dic (TPOLP, p. 43) 
O soneto, que indica na sua primeira quadra tratar de assunto "grave", na verdade, retoma o tema da embriaguês, frequente, sobretudo na ilha de Santo Antão, sede da fabricação do grogue ou "pinga" cabo-verdiana. Eugénio Tavares, não concordando com a pecha de indolência e bebedeira imputada ao homem cabo-verdiano - posicionamento explícito no texto jornalístico "Os indígenas de Cabo Verde são desleixados, indolentes e bêbados?" (TPJ, p. 106), no qual fazia a defesa dos seus compatriotas face aos juízos de valor feitos pelos europeus - coloca teatralmente dois doutores, provavelmente brancos e colonialistas, discutindo o assunto.

O preconceito fica patente, tanto na afirmação enfática de que somente os crioulos bebem e "perdem a mioleira" (“brancos nunca!") e pelo (des)qualificativo "manada", atribuído aos cabo-verdianos, desta forma animalizados.

O último terceto, no entanto, acaba por valorizar a produção humana do cidadão crioulo que fabrica o grogue, adjetivando o resultado de seu trabalho como "cana que divina parece mais que humana". Assim, está provado que os crioulos conservam os seus "miolos", em oposição ao exposto na segunda quadra, e a situação exposta provavelmente evoca a importância da produção do grogue no cenário do arquipélago, como um dos elementos da cultura e da economia.

A distribuição da população cabo-verdiana por gênero é também ironizada por Nhô Tatai. No período colonial, o aumento do número de mulheres com relação ao dos homens agravou-se devido à emigração masculina em busca de sobrevivência das famílias. Observemos como Eugénio Tavares trata o assunto na ilha Brava:

Há nove mil robustos habitantes

Na nossa Ilha. Desses tantos seres Se vê que mais de seis mil são mulheres,

Sendo varões só os três mil restantes.

Desses três mil só dois são celebrantes;

Dando-se que, para cumprir deveres

Do bíblico crescei, e mais misteres, Não há, de modo algum, homens bastantes!

Uma sala de baile, a Brava! À roda, Se sentam mais de cinco mil madamas

Que a dança atrai, os corações em chamas.

Se cada dama não ceder seu par

(Como se sabe que é de lei, e é moda)

Três mil mulheres ficam sem dançar!

(TPOLP, p. 43, grifos nossos) 
Segundo os argumentos de Nhô Eugénio, a monogamia não pode ser dominante em Cabo Verde, para que a "dança" do "crescei e multiplicai-vos" possa ser executada. O poeta desloca a palavra bíblica deslocada para um contexto pagão, profano, que foge totalmente aos princípios católicos. O baile cabo-verdiano e a música constituirão as metáforas responsáveis pela erotização da cena e da ilha ("Uma sala de baile, a Brava!").

Por outro lado, alguns poemas deixam entrever uma visão androcêntrica das condutas femininas, marcando-as com a possibilidade de traição, a "perdição" e, por vezes, com a punição moralizante do adultério por meio da morte.

O longo poema "O Pescador", de estrutura narrativa, acompanha a trajetória daquela personagem do paraíso ao inferno, em correlação à trajetória da esposa, do lar honrado à lama e ao "lodo", que também será referido no poema "Perdida".

\section{O Pescador}

Ao primeiro clarim dos galos, ia Lançar ao mar a barca que pousava Na praia. E sobre as águas da baía, Silencioso e forte, deslizava.

Dobrava a ponta, ao longe, que, estendida Pelo mar dentro, em sombras, negra e enorme, Lembrava uma cabeça enegrecida De crocodilo, monstruosa, informe

E pairando, depois, na bruma, ao largo, Lançava as linhas na água acinzetada, Diante da ilha, imóvel, no letargo Plutónico da terra resfriada.

Pescava imenso tempo à fraca luz Das estrelas trementes sobre as águas: Lá em baixo o farol furava, a flux, A noite, erecto e firme, sobre as fráguas.

Clareava pouco a pouco o céu em frente. No mar chapeava, em cauda de cometa, $\mathrm{O}$ primeiro sorriso alvinitente Da aurora a escorrer oiro e violeta.

Então, de sobre o mar, a barca arfando, E o pescador à popa debruçado, Eram uma só mancha negrejando No frio amanhecer acinzentado. 
Ao repontar o sol, puxava a barca.

Mandava o peixe, em cestas, a vender,

$\mathrm{E}$, mais feliz que um bispo, ou que um monarca,

Repousava, cumprido o seu dever.

Mantinha assim a prole e a companheira

Num trilho de honra, o mais nobre dos trilhos,

Passando a vida, numa verdadeira

Noção do bem, entre a mulher e os filhos.

Nos dias de descanso repousava

De sobre a praia, à sombra da cidade,

Rodeado da família; e então lhe dava

Novo vigor e sã felicidade.

Mas uma madrugada, de repente,

Seu sorriso se cava em contracção

De sofrimento amargo. E docemente,

Curvou a fronte escura para o chão.

Sonhou, ou viu, qualquer coisa tremenda

Que lhe abismou o espírito na dor.

E entrou, de então, na sua pobre tenda,

A suspeita, com todo o seu horror.

Viu a mulher sorrir não sei a quem...

Depois, ouviu-a, em sonhos, num gemido,

Lançar à lama a auréola de mãe,

Cobrir de lodo a honra do marido.

Então o pescador suspende a luta.

Contempla, triste, a ruína da sua alma,

E numa dor serena e resoluta,

Desce à morte moral em fria calma.

Fugir, na sua barca, e nunca mais

Voltar à riba em que fizera o ninho?...

Ou regressar aos páramos glaciais

Do túrbido Não-Ser?... Torcer caminho,

Pôr fogo a esse seu ninho desfeito

Fazendo do ódio e da paixão rastilhos,

Era tirar o incêndio do seu peito,

E lançá-lo na vida de seus filhos.

E foi assim que o triste condenou-se

À formidável dor, à dor pungente

De uma existência cruciante e doce,

Morrendo pouco a pouco, estoicamente,

Mártir do amor, coroado de espinhos,

Sofrendo qual jamais sofreu alguém,

Só para não deixar os seus filhinhos

Sem o amor de sua triste mãe. 
Repara, minha filha: um paraíso

Era a choça do pobre pescador;

Para a tornar inferno, um só sorriso

Bastou, numa ilusão falaz de amor!

(TPOLP, pp. 47-49, grifos nossos)

Este poema, composto em quadras e por enjambements que articulam os versos com leveza imprimindo-lhes um ritmo prosaico, mistura, contudo, ressonâncias da poesia ultrarromântica a situações trágicas.

O título é o leitmotiv a partir do qual se desenvolve a história, a princípio em ambiência serena, própria da felicidade dos simples, tão decantada na poesia romântica.

Assim, se a descrição da natureza e das ações do pescador evoca a vida simples de um homem que se lança ao mar para buscar o sustento de sua família, ela serve para construir paralelamente um cenário paradisíaco que será pouco a pouco desconstruído. A imagem do crocodilo, a "cabeça enegrecida", "monstruosa, informe", na segunda estrofe, indicia o conflito que se desenrolará e o desfecho trágico da história.

Podemos observar o contraste entre a paz anterior ("mais feliz que um bispo, ou que um monarca,/ Repousava, cumprido o seu dever"; "Rodeado da família; e então lhe dava/ Novo vigor e sã felicidade", exposta ao longo das nove quadras iniciais, e a ruptura desse estado ("Mas) na décima quadra. Dividido em duas partes, a tese e a antítese, o poema descreve a queda ao inferno, nas nove últimas quadras, do pescador abatido pela suspeita ("Sonhou, ou viu", "ouviu”) a respeito da fidelidade da esposa.

A tragédia do pescador reside no dilema entre "fugir na sua barca", morrer ("regressar aos páramos glaciais/ Do túrbido Não-Ser", matar a esposa e os filhos ("Pôr fogo a esse seu ninho desfeito") ou permanecer em estado de "morte moral", "morrendo pouco a pouco, estoicamente", como "mártir do amor, coroado de espinhos/ Só para não deixar os seus filhinhos/ Sem o amor de sua triste mãe".

Enquanto o homem deseja vingança, o pai é obrigado, pelos próprios princípios morais e pela própria consciência, a abandonar seus possíveis projetos de reparação para conceder uma vida correta e normal aos filhos que continuarão amando a mãe.

O "contador de estórias", que se revela na última estrofe, parece se um pai que transmite uma lição à sua filha: a de como deve se conduzir uma mulher honrada.

Repara, minha filha: um paraíso

Era a choça do pobre pescador;

Para a tornar inferno, um só sorriso

Bastou, numa ilusão falaz de amor! 
O poema encena uma situação de oralidade, mas sua linguagem de constrastes, de exageros, desembocando num clima soturno e numa moral burguesa maniqueísta remete o leitor a ecos do estilo ultrarromântico luso de, por exemplo, amores de perdição e salvação.

O poema "Perdida", com estrutura semelhante, parte de uma circunstância de alegria para a decadência dos bordéis: a personagem feminina transita de "anjo" a "cabra", "perdida" nos bordéis", "de taberna em taberna":

\section{Perdida!}

Recordas-te daquela rapariga

Tão doida, mas tão linda, que bebia,

Dando-lhe o vinho alegre p'ra a cantiga,

Trinando pelas ruas todo o dia?

Talvez nem já te lembres! Muitas vezes

O exemplo te mostrei dessa infeliz;

E escutavas as minhas catequeses

De moral, sacudida em frenesis!

E quando me dizias: - Ali vai

A inditosa feliz! Não tem cuidados!

Não tem carrasco! Não tem mãe, nem pai!

Nem traz prantos nos olhos deslumbrados! -

Eu quase sempre, então, te respondia

Com palavras serenas mas amargas,

Mostrando-te o abismo que rugia,

Sob os passos da triste, ameaças largas:

- Vendo-a passar a rir e a gargantear,

Braços erguidos, a dançar na rua,

Não podes, de certeza, adivinhar

O sofrimento que em sua alma estua!

O mal do amor é um medonho abismo,

Que atrai as almas, que as empolga e arrasta.

A morte, às vezes, vence o fatalismo

Do amor, e dele as vítimas afasta.

Criou-se essa pequena no regaço

De uma família honesta. Um sedutor

Levou-a, um dia, a escorregar um passo,

E deu nisto que tu estás vendo, flor!

Ante-manhã levanta-se e mergulha

O corpo pálido nas águas vivas

Do mar. Depois parece uma faúlha

Incendiando alegrias explosivas 
De gargalhadas francas, retinentes, Pelo mercado, e pelas ruas claras, Junto de outras perdidas, inconscientes Que Amor também imola em suas aras.

Adora a viola, o vinho e a laranja... Os marinheiros acham-na adorável... De taberna em taberna é que ela arranha A comoção que a faz insaciável...

Uma vez um polícia insulta-a: - Cabra! Ergueu altiva a fina perna nua, Vibrou-lhe um estalo sobre a face glabra:

- Vês-me na testa o que trazes na tua? -

Depois, foi um horror! Chegaram mais Soldados furiosos. Foi levada, Para a prisão, de rastos, desde o cais, Ensangüentando as pedras da calçada!

Hora depois, abriam-lhe a gaiola, E voava, de novo, em liberdade, Cantando alegremente ao som da viola, Pelas ruas e praças da cidade.

Pois filha, essa infeliz já não existe. Ontem seguiu, no esquife do Hospital, Imóvel, lívida, despojo triste, A apodrecer no seu ninho final!

Não mais canta a garganta cristalina! Não mais comove a dor dos seus olhares! Tornou-se lodo! Aí tens tu a sina Dos lírios ideais dos lupanares!

Não é melhor um lar honesto e pobre? Um carrasco brutal? Filhos? Canseiras? O frio, a fome e a dor? Não é mais nobre Leite nos seios? Palidez? Olheiras?

Os vestidos de seda são tão caros, Oh! pobres vítimas vindas do nada!... E os homens, os mais deles, tão avaros, Duma perversidade insaciada!...

Milagres tem às vezes feito o amor Desatolando os anjos dos bordeis... Mas isso é muito raro... Minha flor, O egoísmo humano não conhece leis...

(TPOLP, pp. 49-51, grifos nossos)

$\mathrm{Na}$ primeira estrofe, a linda rapariga, que "criou-se [...] no regaço/ De uma família honesta", já é apresentada num espaço dionisíaco ("bebia”, "vinho”, "cantiga”), 
como um "exemplo" reprovado (“doida"), na segunda e na terceira estrofes, por um eu lírico moralizante que dialoga com um receptor feminino ("e escutavas as minhas catequeses/ De moral", "E deu nisto que tu estás vendo, flor!”) e antecipa o final desfavorável da protagonista ("infeliz", "sacudida em frenesis", "inditosa", "Não tem cuidados!/ [...] Não tem mãe, nem pai!". Se lembrarmos do poema anterior, o pescador não mata a esposa para que seus filhos tenham pais e, provavelmente, não precisem trilhar os mesmo caminhos da "perdida".

Neste poema, "Perdida", o leitmotiv é a rapariga linda e aventureira e a moral androcêntrica se repete, num trágico desfecho: "Um sedutor/ Levou-a, um dia, a escorregar um passo [...]". A sensualidade, metaforizada na dança, como no poema anteriormente examinado, significa a "perdição" para a mulher ("Braços erguidos, a dançar na rua"). Gradativamente, seu comportamento a leva à morte:

Foi levada,

Para a prisão, de rastos, desde o cais,

Ensangüentando as pedras da calçada!

$[\ldots]$

Pois filha, essa infeliz já não existe.

Ontem seguiu, no esquife do Hospital,

Imóvel, lívida, despojo triste,

A apodrecer no seu ninho final!

Não mais canta a garganta cristalina!

Não mais comove a dor dos seus olhares!

Tornou-se lodo! Aí tens tu a sina

Dos lírios ideais dos lupanares!

[...]

Oh! pobres vítimas vindas do nada!...”

A opção para "desatolar estes anjos dos bordéis" será proposta na décima sexta estrofe: a vida familiar, mesmo que sob o jugo de um marido violento:

Não é melhor um lar honesto e pobre?

Um carrasco brutal? Filhos? Canseiras?

O frio, a fome e a dor? Não é mais nobre

Leite nos seios? Palidez? Olheiras?

Ao ingressar no espaços abertos das ruas, lugar público por excelência, e do cais, tomado pela presença de marinheiros, viajantes e aventureiros, a mulher "perdida" se opõe àquela que transita no espaço privado, a mulher mãe assexuada ("leite nos 
seios", "filhos"), habitante de um espaço "honesto" e "nobre", mesmo que à força de sacrifícios (“pobre”, “canseiras”, “frio”, “fome”, “dor”, “palidez”, “olheiras”).

Antilírico, esse poema, bem como o anterior, adota um estilo narrativo, em "voz alta", que faz o leitor saber, ao final, que é com uma filha ou uma mulher mais nova, que necessita de exemplaridade, que se fala.

Naturalmente, o fim da perdida não tem nenhum ingrediente de alegria ou de felicidade. No fechamento da história, na última estrofe, a sentença final não deixa opção: é possível que uma moça "perdida", vivendo num bordel, encontre o amor, um "milagre" que a salve, "mas isso é muito raro", afirma o poeta-narrador.

O poema "Noite de S. João", também com um fio narrativo ("Contava-se na aldeia o triste caso"), evoca uma festa tradicional de Cabo Verde ("uma ardente noite de S. João") em que se dança sensualmente o Colá, e toma como exemplo outra "infeliz", antes "uma rapariga alegre e linda,/risonha e sã", como no poema "Perdida", que "casara nova" (um "sonho infantil",22) e depois, em virtude da emigração masculina, torna-se uma adúltera cheia de culpas:

Noite de S. João

Contava-se na aldeia o triste caso

Dessa infeliz que, repentinamente, Morrera de alegria, num ocaso

De outono, à volta do marido ausente.

Era uma rapariga alegre e linda, Risonha e sã como um bom sol de abril.

Casara nova, muito nova ainda,

Mal desperta do seu sonho infantil.

O marido embarcara muito cedo

A procurar fortuna sobre o mar, Sem ver o mal que lhe espreitava, tredo, Os sonhos de oiro e rosa do seu lar.

E dando ao gelo de uma longa ausência

O seu lugar no tálamo nupcial,

Sacrificava, na cruel demência

Da luta, a alma da esposa angelical.

Passou um ano intérmino e fremente, Numa existência plúmbea de viúva; Pranteavam mágoas mudas, vagamente, Seus olhos doces como bagos de uva.

\footnotetext{
${ }^{22}$ Considere-se que os casamentos precoces eram uma realidade no arquipélago até bem pouco tempo.
} 
Mas ia à fonte, e vinha; trabalhava $\mathrm{Na}$ lavra, pelos campos, como um homem; $\mathrm{E}$ as esperanças de sua alma escrava,

Eram nuvens que passam e se somem.

Por uma ardente noite de S. João

As flechas de um olhar de amor, traiçoeiras

A trespassaram: foi-lhe o coração

Ardendo enquanto ardiam as fogueiras...

Depois sobrevieram dias quentes Errando chamas de oiro pelo céu;

Penas das suas asas resplendentes:

Nuvens como retalhos de algum véu...

Em seguida, novembro: os céus toldados

Cerrando-se sombrios sobre a vida;

Raios de sol morrendo desmaiados,

Em amarguras de hora de partida...

As acácias perdendo toda a graça

Das rendilhadas franças verde-negras...

Soprando, o vento atroz que, quando passa, Sem um abrigo deixa as toutinegras...

Iates regressando, no fim do ano,

Como bandadas claras de albatrozes, Depois de atravessar o largo oceano,

Fechando as asas cândidas, velozes...

Um desses barcos lhe trouxera o ausente.

Quando ela soube, a nova fulminante

Apunhalou-lhe o coração doente,

Seu doce coração de esposa e amante...

Empalidece a fronte angustiada:

Gotejam pranto os olhos seus tristonhos;

Cobre-lhe a carne fria e torturada

O suor suplicante dos maus sonhos...

Quando chegou a hora de deitar,

Reconta, o recém-vindo, o seu naufrágio

Na noite de S. João: iroso o mar

Bramia em volta; e como um mau presságio,

Os dois faróis de bordo, de repente

O mar os arrancara! E pôs-se a crer, Então, que nessa noite, certamente, A vida, ou mais, talvez, ia perder...

- Eu estava ao leme. O barco sufocava

Nas vagas alterosas, espumantes.

Em volta, noite horrível se cerrava,

Soltos, na noite, os ventos ululantes. 
Vi, num momento, um negro abismo aberto.

Ergui os olhos para os céus furiosos.

Pensei em ti. Ia morrer, decerto,

Sem ver a luz dos teus olhos formosos.

Depois, milagre! Vi-te lentamente,

Subindo ao céu, levada na bonança

Das tuas asas brancas, docemente,

Como a visão serena da esperança!

Pouco a pouco se foi no mar quebrando

A raiva dos tufões. No céu rasgou-se

O toldo frio e plúmbeo. Serenando,

Caíra o vento num soluço doce...

Mas, ai! novas suspeitas me assaltaram:

Vira-te em sonhos a subir ao céu...

Morta, talvez? Pesares me toldaram

Minhas saudades com um negro véu!

Mulher! Naquela noite de S. João, Nas convulsões dos ares revoltados,

Foi teu amor, talvez, a salvação

Dos meus dias de morte ameaçados! -

Assim falou o infortunado esposo

Beijando a triste. Mas, nesse momento,

De miseranda o espírito lutuoso

Voou ao céu, num derradeiro alento!

Ai! dos que morrem! É mortalha fria,

O esquecimento, dos que a morte gela...

E a triste que morrera de alegria,

Nem o viúvo já se lembra dela!..

(TPOLP, p. 51-53, grifos nossos)

Em virtude da "longa ausência" do marido, na noite de S. João, "as flechas de um olhar de amor, traiçoeiras/ A trespassaram: foi-lhe o coração/ Ardendo enquanto ardiam as fogueiras". Ao mesmo tempo, em superposição cinematográfica, a "demência" da paixão consome a mulher e o marido naufraga em "iroso mar".

Ironicamente, é a imagem da esposa amorosa que o anima a salvar-se:

Mulher! Naquela noite de S. João,

Nas convulsões dos ares revoltados,

Foi teu amor, talvez, a salvação

Dos meus dias de morte ameaçados! 
O ambiente terrífico descrito no poema ("os céus toldados/ Cerrando-se sombrios sobre a vida;/ Raios de sol morrendo desmaiados", "o vento atroz", "mau presságio", "Em volta, noite horrível se cerrava,/ Soltos, na noite, os ventos ululantes") alia-se à culminância, também ultrarromântica: no leito de morte da esposa o marido desfia esta longa narrativa. No entanto, o esquecimento será a maior "punição" do poeta-narrador à personagem esposa infiel: "Nem o viúvo já se lembra dela!”

Nestes três longos poemas de caráter exemplar, pode-se observar que a mulher é considerada vítima fatal do amor romântico, deixando-se embalar pelas ilusões e colocando em desgraça a si mesma e aos seus. O risco de desmantelamento da família que o seu comportamento pode provocar tem na moralidade dos poemas a mais cruel das condenações; inscrita nos códigos sociais, que decreta a tristeza e o final sinistro para as personagens femininas transgressoras.

A par das personagens femininas mal-sucedidas, Eugénio Tavares tematiza ainda o amor que redime, na figura da "mulher feliz", "honesta e mansa". O lar, como no poema "Perdida", é de pobre e, como no poema "O pescador", é “ninho".

\section{Ressureição}

Entremos neste santo lar de pobre, Em sombras rumorosas escondido: (Sob este colmo idílico que o cobre, Parece um ninho num rosal florido!)

Que vêem os ingênuos olhos teus? Claridade de paz e de bondade; O asseio, a ordem, e esse olhar de Deus Doce e amorável da felicidade.

Crianças lindas como madrugadas; Mulher feliz, mulher honesta e mansa, Dona do olhar de deusas ou de fadas Que na alma as tempestades abonança.

Mulheres de falas doces, olorosas, (A flor das almas plácidas e justas!) E cujas mãos divinas, milagrosas, Fazem florir as landes mais adustas.

E de enxada na mão, cavando a terra Para fazer brotar o pão e a flor Nas veigas férteis do sopé da serra, Rijo e fecundo, o bom trabalhador. 
A filharada corre, brinca, salta! Ágeis e lépidos, como cabritos

Sobem à crista mais audaz, mais alta,

Onde as águias se aninham nos granitos.

Aí tens tu a sã felicidade:

Colher o pão com o suor do rosto;

Viver e amar em paz, em liberdade

Desde que raia a aurora até sol posto.

Queres tu, porém, os dolorosos

Primeiros passos deste amor coroado?

Volve os teus olhos tristes e formosos

Para os escuros dias do passado:

Domingo. Meio dia. Esmorecida

Dormita a aldeia. O céu, em luz, esplende.

As plantas enlanguescem. Toda a vida

Amodorrada e frouxa se suspende.

Os milharais inclinam as bandeiras

Amortecidas das bafagens quentes

Que sopram deslocando, passageiras,

Os ares tórridos, incandescentes.

Entretanto a taberna regorgita;

São lavradores que, depois de missa,

Vêm espantar suspeitas de desdita

$\mathrm{Na}$ alegria do vinho esquecediça.

Uns bebem pouco; (e são, esses, tão poucos!)

Dos mais, a maioria não resiste

Bebendo o pão dos filhos como loucos,

Guardando nuvens num futuro triste.

Ao canto do balcão, um cavador, Imberbe ainda, jaz uma agonia

De engulhos. Ai, tão novo, e já no horror

Do vício... A noite alonga-se, sombria...

Arrasta-se, sozinho, estrada fora,

Emurchecido como um cão vadio...

Órfão, jamais sorriu-lhe na alma a aurora...

Seu lar é um sepulcro negro e frio...

Escorrega; despenha-se; lá vai

Parar ao fundo escuro do valado...

A noite desce e gela... A chuva cai...

Ao longe o mar soluça, amargurado... 
Raia a manhã. As lavadeiras passam

Descem a levantá-lo do lameiro.

Parecem avezinhas que esvoaçam

Em bando alegre, fervido, palreiro...

Uma, que entretanto o erguera, condoída

Falou às companheiras: - Faz-me dó

Pensar na triste e amargurada vida,

Sem mãe e sem irmãs, de um homem só!

Que faz um pobre que não tem alguém

Numa existência solitária, espessa?

Abraça o mal, e lança fora o bem...

Talvez até para morrer depressa. -

Encheram-se de lágrimas os olhos

Do triste cavador. Do seu viver

Os golfos abismais, cheios de escolhos

Sondou, então, num pávido sofrer.

E suplicou: - Mulher, a tua mão!

Uma réstea de luz do sol sagrado

Do teu olhar angélico!... Ou senão,

Deixa-me aqui morrer abandonado...

Casaram, minha filha. E nesse dia,

No algar social brilhou mais um farol..,

Por cada lar feliz que o amor cria,

Acende Deus, no caos, mais um bom sol.

(TPOLP, pp. 56-58)

As estrofes segunda a quinta revelam os atributos desta mulher: paz, bondade, asseio, ordem, olhar de Deus, de deusas ou de fadas, doce, amorável, mãos divinas, milagrosas. Mas mãos que cavam a terra, mãos de trabalho.

A partir da nona estrofe, o poema faz um flashback e apresenta o seu futuro marido, um jovem "imberbe", salvo por ela de um "lameiro" onde o atirara o vício da bebida:

Arrasta-se, sozinho, estrada fora,

Emurchecido como um cão vadio...

[...]

Escorrega; despenha-se; lá vai

Parar ao fundo escuro do valado...

[...]

Raia a manhã. As lavadeiras passam

Descem a levantá-lo do lameiro.

[...] 
Falou às companheiras: - Faz-me dó

Pensar na triste e amargurada vida,

Sem mãe e sem irmãs, de um homem só!

Essa "angélica" mulher, de certa forma, constitui um exempla que redime as "perdidas" enfocadas nos poemas anteriormente examinados. A última estrofe, na fala de um narrador, estrutura que já demonstramos funcionar como uma finda nos poemas eugenianos de cunho moralizante, dirige-se a uma receptora que adentra, juntamente com o poeta, aquele lar santificado, palco dos acontecimentos relatados:

Casaram, minha filha. E nesse dia, No algar social brilhou mais um farol.., Por cada lar feliz que o amor cria, Acende Deus, no caos, mais um bom sol.

Para finalizar, queremos ressaltar um poema-homenagem ao escritor caboverdiano Pedro Cardoso, contemporâneo de Eugénio no período nativista, que enfatiza, em estilo ultrarromântico, os valores pátrios, a necessidade do combate e da revolução:

\section{Hinos}

I

A Pedro Cardoso

Revolução ou morte! eis o nosso dever.

A paz é, já, um crime; e morte infame, a vida.

E se havemos de, irmãos, um dia apodrecer

No ventre desta terra infausta, tão querida;

Se a Pátria santa ao mal temos que ver rendida, Se a aurora do combate um dia há-de romper, Se a lágrima, e o suor, e o sangue hão-de correr, Avermelhando o mar e a terra envilecida;

E se hão-de um futuro incerto, derramá-los Filhos do vosso amor, às mãos dos mercenários, Pátria e filhos - irmãos! - tentemos nós salvá-los!

Morte ou Revolução: que não há cobardia Que iguale a de legar a filhos os calvários De nomes com brazões de lodo e vilania!

(TPOLP, p. 31)

Esta temática será mais desenvolvida na obra em prosa, especialmente a jornalística, como já foi ressaltado no capítulo anterior, do que na obra poética. 


\section{4 - Núcleo da reflexão filosófica e religiosa}

Os bons vi sempre passar

No mundo graves tormentos;

$E$, para mais me espantar,

Os maus vi sempre nadar

Em mar de contentamentos.

Luís de Camões

$\mathrm{Na}$ trilha de um dos temas maneiristas da lírica camoniana que atingem uma dimensão filosófica, o "desconcerto do mundo", Eugénio Tavares elabora um de seus mais belos sonetos:

Ergueu-se o Mal sombrio contra mim:

Decorrem noites longas e sombrias;

Arrastam-se sem luz pesados dias;

Parece este suplício não ter fim!

Os maus passam a vida num jardim

Reflorescido em gozos e harmonias;

Enquanto as mais terríveis agonias

Os bons as sofrem, sem que um dia, enfim,

Vejam raiar na linha do horizonte

Alvor de paz, em jubileus augustos,

Que a inocência lhes lave e desafronte!

Certo é que Deus não quer outro laurel

$\mathrm{Na}$ fronte melancólica dos justos

Senão esse de espinhos e de fé!...

Praia, Dezembro de 1914 (TPOLP, p. 27, grifos nossos)

De mistura com uma linguagem ultrarromântica (povoada de melancolia, noites sombrias), o pathos agônico maneirista do desengano e do desconcerto opõe os gozos dos maus ao sofrimento dos bons, como no texto de Camões:

\section{O DESCONCERTO DO MUNDO}

Os bons vi sempre passar

No mundo graves tormentos;

E, para mais me espantar,

Os maus vi sempre nadar

Em mar de contentamentos. 
Cuidando alcançar assim

$\mathrm{O}$ bem tão mal ordenado,

Fui mau, mas fui castigado.

Assim que, só para mim,

Anda o mundo concertado.

CAMÕES, 1994, p. 102

No poema eugeniano, no primeiro verso da segunda estrofe, o eu lírico manifesta sua indignação ao constatar que os maus "passam a vida num jardim", impunes, enquanto os bons colhem "as mais terríveis agonias", sem que "na linha do horizonte" (terceira estrofe) surja um sinal de paz que possa amenizar a sua angústia.

Se na primeira estrofe, o eu poemático ressalta a presença do "Mal", das noites longas e sombrias, a escuridão ou tristeza na ausência de "luz"; na terceira, evidencia o desejo de ver "raiar" um "alvor de paz" em que possa celebrar a vitória da inocência sobre a maldade, desafrontando-a.

O eu poético conclui o soneto afirmando que o "Certo é que Deus prefere uma coroa de "espinhos e de fé" "na fronte melancólica dos justos", ao invés de uma "coroa" de glórias, sugerindo, desta forma, que os justos, de acordo com a tradição cristã, precisam abandonar tudo o que é material, transitório, mundano, e passar por provações para, enfim, merecer o "manjar de lutadores, galardão de vencedores esforçados",23 como nos versos de Anchieta.

O poema que se segue continua a tematizar, por antítese, o desconcerto (e a injustiça) do mundo, atribuindo ao eu poemático novamente a coroa de espinhos, signo da paixão do Cristo crucificado, e a exibição de sua agonia em contraste com a alegria dos "malvados". Assim, o Bem e o Mal estão mal distribuídos no mundo pelo "destino" (a moira grega, para a qual não há saída), como já propunha Luís de Camões.

Para os maneiristas, o mundo, como a vida, é encarado sob o prisma de um exacerbado negativismo: é cruel, enganador; um lugar onde imperam a maldade, a desgraça, o caos, os conflitos, a mentira, e onde o homem caminhará, sempre como vítima de um inclemente calvário.

As queixas e críticas dos poetas maneiristas, mercê da reflexão sobre a condição do homem em meio à inversão de valores em sociedades cujo mal era, sobretudo, moral, a denúncia da desordem, da injustiça e da corrupção nas sociedades

\footnotetext{
${ }^{23}$ Verso extraído do poema "Do Santíssimo Sacramento", de José de Anchieta. Cf. MOISÉS, 1983, p. $18 b$.
} 
do seu tempo, que Camões tão bem representou, serão aqui também encampadas pelo poeta cabo-verdiano:

Alevantou-se a Sombra contra mim.

Como um sonho de morte, as noites frias

Envolvem e sufocam os meus dias

Em agonias álgidas, sem fim.

Foi um destino mau que o quis assim.

Aos malvados não faltam alegrias,

Enquanto as mais pungentes agonias

Os bons esmagam. Sem que um dia, enfim,

Vejam raiar na linha do horizonte

Alvor de paz em jubileus augustos

Que os lave da calúnia e os desafronte.

E que Deus recompensa assim os justos,

Nos ombros pondo-lhes pesada cruz,

E na cabeça a c'roa de Jesus.

(TPOLP, p. 27, grifos nossos)

O termo "calúnia", é bom lembrar, certamente alude à situação biográfica pela qual passou Eugénio Tavares, acusado de se apoderar de dinheiro público, um dos motivos para o seu exílio e uma das estratégias usadas pelo governo colonial para retirar da cena cabo-verdiana um feroz adversário.

No soneto abaixo, o eu lírico, também crucificado, mas agora pelo Amor, apela a este Deus severo que "amenize a dura sorte" do amante e interceda, suavizando o coração da mulher amada:

\section{Oração}

Ó Senhor Deus, que a todos nos lançaste

Neste mundo de dúvidas e dor!

Tu que fazes sorrir, pelo frescor

Da madrugada, os lírios sobre a haste;

Tu que recamas o cerúleo engaste

De fogos trémulos de eterno ardor;

Ouve-me tu, meu doce Criador,

Que em dura sorte me crucificaste:

Entre no coração da minha amada, E mostra-lhe a tristeza que me mata,

Às mãos de uma saudade inconsolada! 
Fala-lhe na alma! Dize a essa ingrata

Que a falta dos seus beijos já me traz

Sem um momento de repouso e paz!

(TPOLP, p. 28, grifos nossos)

Marcado pelo ultrarromantismo, o poema expressa um sofrimento exacerbado e a desilusão por um amor não correspondido por parte da "ingrata" amada.

Avultam características de um romantismo tardio em Cabo Verde, como a religiosidade ("Senhor Deus"), a natureza como cenário ("da madrugada, os lírios”), o sentimentalismo e o sofrimento (“dor", “tristeza”, "sem repouso e paz”), a "saudade”.

A má distribuição do Bem, da Verdade e do Amor leva o eu lírico a, finalmente, recusar a existência de um Deus cristão que demonstre indiferença ao sofrimento dos justos e inocentes:

\section{Deus}

Dormes, Sombra enigmática? Repousas, Anojado de ver o fero Mal Cravar, impunemente, o seu punhal No coração do homem? e não ousas

Desviar os teus olhos para as cousas Que fermentam no fundo desse urzal Da alma humana? Será, Deus eternal, Esse teu sono o último, de lousas?

Sentes jorrar o sangue da inocência, E vês correr as lágrimas dos tristes? Não ouves o estertor da consciência

Estrangulada? Indiferente assistes

À acção feroz do crime? Omnipotência!

E teu sono é morte! Não existes!

(TPOLP, p. 17)

O soneto é composto por sete perguntas que vão do primeiro ao décimo terceiro versos, em que a Sombra Onipotente é interpelada em estilo ultrarromântico; as três exclamações, entre o décimo terceiro e o último versos do poema, acabam por constatar, com indignação, a passividade de um Ente Supremo que deveria zelar pela Justiça mundana e para Quem, consequentemente, a sentença deve ser a "morte".

Pólos antitéticos, como a Verdade e a Mentira, compõem o mundo criado por este Deus que parece não ouvir o clamor da dor humana: 


\title{
A Mentira
}

\author{
(Suave é ao homem o pão \\ da mentira, mas depois \\ a sua boca se encherá \\ de pedrinhas de areia.) \\ - Prov. XX, 17
}

O golpe de ar mortal que sopra o Inferno!

Oh Mentira, venéfica serpente

Caminhando de rojo, eternamente,

Da corrupção no fermentar eterno!

Oh bandada de abutres sem governo!

Oh lodaçal rolando, já torrente,

Rio de pus, em cuja vasa ardente

Supura da Alma o Velho mal interno!

Vai arrastando sempre para a treva

O destino do homem sobre a terra!

Destrói o bem; apaga o sol; e leva

À sã virtude o pus da tua chaga!

Que todo o mal que o teu rancor encerra

A lágrima de Amor o lava e apaga!

(TPOLP, p. 29)

A Mentira nada tem a oferecer a não ser o mal. No poema, ela é comparada à serpente, animal que, entre outros significados, no Antigo Testamento (conferir epígrafe) é considerado impuro, ao ser vinculado à imagem original do pecado e de Satanás, que se interpôs entre Adão e Eva, o primeiro casal humano no paraíso.

O substantivo "corrupção", no terceiro verso, bem como "bandada de abutres sem governo!" no quarto, "lodaçal rolando", no quinto e "Rio de pus" no verso seguinte, parecem sugerir o mal causado ao intelectual cabo-verdiano pelo sistema colonial ("governo"), pois este arrasta à treva "o destino do homem" (décimo verso), “destrói o bem” e "apaga o sol” (décimo primeiro verso).

Este símbolo de luz, de princípio vital e de cada recomeço, apresentado na penúltima estrofe, pode, no entanto, ressurgir, segundo o fecho do poema: uma "lágrima de Amor" é capaz de apagar, com sua pureza, a vilania da mentira.

Contrapondo-se à sordidez da mentira, sentimento que atormenta o homem pela falsidade (e que atormentou a vida do poeta Eugénio Tavares), a Verdade é o mote do poema seguinte: 


\section{A Verdade}

Desce do céu a estrela radiosa

Da Verdade. Dir-se-ia uma Rainha

Que sai do seu palácio e se encaminha

A iluminar a Via Dolorosa.

Do verme ao homem, e da urze à rosa;

Da sorte mais feliz à mais mesquinha.

O seu olhar abraça e acarinha,

Como um olhar da Virgem Piedosa.

Nas alvas mãos, mais cândidas que o lírio,

Fulge o sinal dos cravos do martírio.

No peito, em que a Justiça Eterna vela,

Por cada golpe rompe uma alvorada.

Porque a Verdade torna-se mais bela

De cada vez que é crucificada.

Brava, 20 de Setembro de 1919 (TPOLP, p. 29)

Sempre associada à luz, a Verdade chega ao homem como uma "estrela radiosa" que "desce do céu", uma Rainha que "sai do seu palácio" para "iluminar a Via Dolorosa" ou a "Virgem Piedosa" que "abraça e acarinha" o homem em seu "martírio" sobre a terra.

A Verdade, consoladora, pode de início, associar-se ao sofrimento ou aos "cravos do martírio"; todavia, irmã da Justiça, sempre prevalecerá e, por este motivo, "torna-se mais bela/ De cada vez que é crucificada".

O cravo, símbolo da Paixão de Cristo, aparece frequentemente nas representações da Virgem Maria com o Menino Jesus. Imagem da redenção e da ressurreição, alia-se no poema à alvura do lírio, que evoca a pureza da Verdade.

Retomando o exposto no capítulo 1, lembramos que Eugénio Tavares, na sua produção jornalística, sempre posicionou-se a favor da verdade e da justiça: "Verdade, sempre verdade. Verdade a todo o transe. Verdade à custa da paz do meu lar, à custa do bem dos que amo, à custa da minha própria felicidade. [...] Verdade mesmo acima de Deus" (TPJ, p. 58).

Concluindo a abordagem da linha filosófica da produção eugeniana em língua portuguesa, gostaríamos de ressaltar a leitura que o mestre cabo-verdiano realiza de um célebre poema do português Antero de Quental: 


\section{A Morte}

"Morte libertadora e inviolável"

Antero

A morte é uma grande benfeitora

Quem tem, de Deus, essa missão sagrada

De dar repouso à vida atribulada,

De dar a liberdade redentora:

Em seu regaço gélido, onde mora

A paz do não sofrer tão almejada,

Repousa a vaga essência desmaiada

Da dor da humanidade sofredora:

Sua mão regelada e piedosa,

Não é a inexorável mão escura

Que empunha a negra foice tenebrosa;

É nívea mão de amor e de ternura

Que ampara e guarda - eterna mãe bondosa -

Perpetuamente, as almas sem ventura.

Brava, 1890 (TPOLP, p. 16)

Tomando como epígrafe o último verso do poema de Antero, Eugénio insere o tema da morte num contexto de religiosidade católica e no ambiente terrífico do mal-doséculo ultrarromântico ("regaço gélido", "mão escura", "negra foice tenebrosa").

Contudo, o soneto caminha em sintonia com os epítetos anterianos de elogio da morte (série de seis sonetos), encarada pelo poeta metafísico luso com uma filosofia idealista, segundo esclarecimento de António Sérgio" ${ }^{24}$ a morte é "liberatrix" (soneto Mors liberatrix), “consoladora" (Beatrice), irmã do Amor e da Verdade ("Mors Amor”).

Observemos como se constrói o poema de Antero com o qual Eugénio dialoga intertextualmente:

Que nome te darei, austera imagem,

Que aviso já num ângulo da estrada,

Quando me desmaiava a alma prostrada

Do cansaço e do tédio da viagem?

Em teus olhos vê a turba uma voragem,

Cobre o rosto e recua apavorada...

Mas eu confio em ti, sombra velada,

E cuido perceber tua linguagem...

Mais claros vejo, a cada passo, escritos,

Filha da noite, os lemas do Ideal,

Nos teus olhos profundos sempre fitos...

\footnotetext{
${ }^{24}$ In. QUENTAL, Sonetos completos, p. 155. Nota de António Sérgio.
} 
Dormirei no teu seio inalterável,

Na comunhão da paz universal,

Morte libertadora e inviolável!

(QUENTAL, pp. 150-151, grifos nossos)

Em suma, na sua poética multifacetada em língua portuguesa, Eugénio Tavares transita entre os temas e a retórica ultrarromânticos do idealismo amoroso e do mal-doséculo e, em simultâneo, ultrapassa esse estilo tardio em Cabo Verde - herdado do colonizador luso -, pelo humor e pela crítica; aprofunda-se ainda na problemática social e política do arquipélago, denunciando o abandono a que administração colonial reduzira as ilhas. Por fim, eleva suas reflexões aos assuntos filosófico-religiosos, completando o traçado do painel do ideário cabo-verdiano de seu tempo. 


\section{CAPÍtUlO III - MORNAS - CANTIGAS CRIOULAS: POESIA EM LÍNGUA "SABE"}

\section{[...] devemos sempre e sem receio escrever tudo quanto pensamos e sentimos da Morna.}

\section{F. Xavier da Cruz (B. Léza)}

Pouco tempo antes de sua morte, incentivado pelo amigo e poeta português José Osório de Oliveira, Eugénio Tavares (18/10/1867-01/06/1930) selecionou aquelas que eram consideradas as suas mais belas composições em língua cabo-verdiana, confiando ao amigo a edição e publicação da obra em Lisboa.

Com o intuito de dar maior relevo à língua crioula, a seleção do autor deixou de lado as composições escritas em português. Desta forma, em fevereiro de 1932, dois anos após a morte de Eugénio, vem à tona a primeira edição de Mornas - cantigas crioulas, com tiragem de apenas vinte exemplares. Percebe-se, por este dado, o cenário pouco favorável para o conhecimento e a difusão da literatura cabo-verdiana naquela época. É de se observar também a dificuldade de publicação, daí talvez resulte a justificativa de Eugénio para o pouco interesse em deixar a sua produção mornística registrada em livro, sendo necessário o incentivo de um amigo para que tal acontecesse.

Esta primeira edição é composta por vinte e cinco (25) mornas e traz um prefácio, em tom explicativo-profético, em que o autor busca mostrar o seu entendimento sobre o fenômeno da morna. Num esforço de valorização da língua caboverdiana, Eugénio insere, juntamente com a dedicatória ao poeta romântico português João de Deus, a tradução para o crioulo do poema “A enjeitadinha”. É, ainda, digna de nota a inserção de "Bárbara Escrava", famoso poema de Luís de Camões, por quem o bravense nutria grande admiração, traduzido para a língua crioula como "Barbara, Bonita Scraba”.

Acreditamos que não seja demais a transcrição da dedicatória apresentada por Eugénio Tavares, intitulada “Ao altíssimo espírito de João de Deus”:

Pois que o plectro de João de Deus, luzeiro do ibero lirismo, é a asa das nossas inspirações, e é o fogo sagrado de nossos altares; dos que cantam e dos que sofrem; dos que amam e dos que ardem no culto da Raça glorificada na serena magestade do Génio; penso que, de mal, poucos me alvejarão porque ouso abrir este pequeno florilégio de

\footnotetext{
${ }^{25}$ Gostosa, deliciosa.
} 
cantigas crioulas com a chave de oiro duma versão, no dialecto que se fala nesta ilha Brava, da "Engetadinha" do grande lírico.

De joelhos sobre o moimento de João de Deus (menos para ser visto que para me sentir no dever do meu culto), deponho este pobre rosário de canções, que, em verdade, à secura do papel, pouco trazem do aroma e da cor com que desabrocham, como um sangue vivo de cravos e de rosas, nas bocas das raparigas da minha terra, que com tanto amor - única honra minha - as decoram e cantam (TMCC, p, 25).

Julgamos necessário cotejar o poema original do romântico português à versão crioula de Eugénio Tavares, para posteriores reflexões acerca de seu processo poético.

Engetadinha (de João de Deus)

- Cusa é bo tem, nha fijinho?

- 'N tem fome, a má'n tem friu.

- Mas, bô sô na es caminho, Mâ passo sem sarrâ pena, Que jâ escapâ de sê ninho!... Nha fijo, bo ca tem Mai?

- Na nha bida'n ca conchel...

Desde que'n necê'n perdel...

Parecê'n ma'n ca temba Mai...

- Bô é mas feliz que mi,

Que temba de meu, e el morré... (TMCC, p. 29).

\author{
A enjeitadinha \\ - Por que choras tu, anjinho? \\ "Tenho fome e tenho frio!" \\ - E só por esse caminho \\ Como a ave que caiu \\ Ainda implume do ninho!... \\ A tua mãe já não vive? \\ "Nunca a vi em minha vida; \\ Andei sempre assim perdida, \\ E mãe por certo não tive!" \\ - És mais feliz do que eu, \\ Que tive mãe e... morreu! \\ (João de Deus).
}

Consoante com o processo de formação da série literária cabo-verdiana, o texto de Eugénio, ainda marcado pelo cânone literário do colonizador, já transfere a substância poética para o contexto crioulo, tomando como mote o tema da enjeitadinha para dar voz à tradição oral (“canções”) preservada e propagada pelas raparigas anônimas (e quem sabe enjeitadinhas) de Cabo Verde.

O poema romântico de João de Deus é construído em forma de diálogo, podese dizer, entre duas tristezas, a do eu lírico e a da rapariga enjeitada, uma vez que ambas lamentam a falta da mãe: uma, por tê-la perdido antes mesmo de conhecê-la e a outra, após ter sentido o calor do amor materno, perde-a para a morte, julgando a sua dor maior. Esta temática já nos dá uma idéia de que a leitura de João de Deus por parte de Eugénio Tavares possa ter contribuído para despertar no seu espírito de poeta uma preocupação com o sofrimento alheio, o que ficará mais explícito na leitura de sua produção jornalística e epistolar.

Mornas - cantigas crioulas traz, ainda, um posfácio escrito por José Osório de Oliveira, enfatizando a importância da obra de Eugénio Tavares no resgate da tradição 
oral, patrimônio imaterial cabo-verdiano expresso em língua crioula. Nele encontramos uma definição esclarecedora sobre a modalidade musical identitária de Cabo Verde:

Morna é o nome que designa, ao mesmo tempo, a dança e as canções típicas de Cabo Verde. Ritmo do baile, palavras e música das canções, são coisas inseparáveis. Não se trata, com efeito, duma dança acompanhada de palavras como qualquer outra. $\mathrm{O}$ facto do povo de Cabo Verde dançar a morna cantando (repare-se que não se trata duma dança de roda), indica claramente, que, para ele, gestos, letra e melodia são formas indistintas do mesmo ritmo interior. Nunca, com efeito, a alma dum povo encontrou, tão perfeitamente, a sua expressão, numa única manifestação de $\operatorname{arte}^{26}$. Cabo Verde não tem, de facto, mesmo em estado rudimentar, artes plásticas ou decorativas que caracterizem a sua gente. Quanto à literatura e à música, todas as suas manifestações peculiares tomam a mesma forma. Pode afirmar-se, portanto, que a morna resume em si todos os sentimentos e condensa todas as aspirações artísticas dos caboverdeanos (OLIVEIRA in: TMCC, p. 77, grifos nossos).

Com o objetivo de comemorar o $102^{\circ}$ aniversário de nascimento de Eugénio Tavares, em 1969, a Liga dos Amigos de Cabo Verde em Luanda publica a $2^{\text {a }}$ edição de Mornas - cantigas crioulas. Esta nova edição, além das vinte e cinco (25) mornas iniciais, apresentou mais duas. Nela inseriu-se, ainda, uma adenda, na qual podemos encontrar algumas composições em língua portuguesa como: "Canção ao mar" (Mar eterno), "Camponesa formosa", "Meu bem" (Cai no mar), "Canções aladas". Destaca-se na edição um dos poemas mais representativos de Eugénio Tavares: "Triste regresso", em cópia do original com a caligrafia do autor e a sua assinatura. A intenção dos editores, então era angariar recursos para que fosse possível encomendar e pagar um busto do poeta para ser colocado no jardim que leva seu nome na cidade de Vila Nova Sintra, na ilha Brava, fato que só veio a se concretizar anos mais tarde, com o empenho de outros admiradores.

É importante esclarecer que o presente trabalho teve a preocupação de disponibilizar ao leitor que não domina a língua crioula uma tradução inédita da maioria das composições de Eugénio publicadas em Mornas - cantigas crioulas. Para tanto, e visando melhor compreensão do conteúdo nelas expresso, contamos para a tarefa de tradução livre com o apoio de Verónica Oliveira Ramos, cabo-verdiana da ilha de São Vicente e jornalista formada pela Escola de Comunicação e Artes - ECA, da

\footnotetext{
${ }^{26}$ Apesar de grifarmos, lembramos que a nossa leitura da afirmação de José Osório de Oliveira é acompanhada de certa reserva, visto que a cultura cabo-verdiana, riquíssima, não pode ser reduzida à morna como única manifestação artística.
} 
Universidade de São Paulo. Na busca pelo aperfeiçoamento do trabalho realizado pela falante nativa, foi feita uma revisão, acompanhada pela Professora Doutora Simone Caputo Gomes, no intuito de dar à tradução um cunho mais literário.

Destacamos que nas mornas "Hora de Bai" e "No Cantero de Nha Peto" mantivemos a tradução produzida por Manuel Ferreira e Gabriel Mariano, respectivamente.

Conforme nos apontam Moacyr Rodrigues e Isabel Lobo, dois renomados pesquisadores da morna, a antológica obra de Eugénio Tavares, Mornas - cantigas crioulas, chegou até nós graças a José Osório de Oliveira, "que muito se interessou, com a sua sensibilidade de homem culto, por esses aspectos literários da morna e pela literatura em geral que se fazia em Cabo Verde" (1996, p. 64). Acrescentam os autores que as mornas inseridas nesta obra: "Reflectem a vida edênica que se vivia na ilha Brava da época e que a maior parte dos cabo-verdianos chegou a conhecer e a cantar nos nossos dias" (Op. cit., p. 65).

Façamos, aqui, uma pausa para adentrar o "mundo da morna" e, posteriormente, tratar da produção poético-mornística de Eugénio Tavares, considerado por Pedro Cardoso "o Catulo-Cearense Caboverdeano" (1983, p. 26) e de sua significação para a trajetória do gênero musical e da literatura de Cabo Verde.

\section{1 - Morna, modalidade musical identitária cabo-verdiana: origens e polêmicas críticas}

Todo o Cabo Verde se interroga sobre o aparecimento da morna e somos nós que, desde que chegámos, plantados sob o sol oficial do meio-dia, temos de remoer um enigma que atormenta os musicólogos desde há muito.

Jean-Yves Loude

Julgamos de extrema importância para os Estudos Cabo-verdianos estabelecer uma reflexão sobre o papel da morna (modalidade musical) na expressão da cultura e da identidade do povo crioulo.

Acerca da relação que o homem de Cabo Verde nutre com a morna, vale a pena lembrar o que Manuel Ferreira enfatiza: 
O Cabo-Verdiano imprime à morna o expoente máximo da sua sensibilidade. Através dela exprime a saudade do que deixou, do que não viveu, do que desejaria ter vivido e ainda de tudo o mais quanto nos estratos profundos do seu subconsciente se agita e desencadeia, em torrente lírica: o amor, a nostalgia, o sofrimento (1975, p. 174).

E acrescenta:

[...] Tão ligada anda ela na dolência, na nostalgia, na vivacidade amorosa, na ternura, na sua amorabilidade, a tudo o que a rodeia no Arquipélago: gentes, sentimentos, virtudes, drama, solidão, que ela se transfigura em factor da própria geografia sentimental crioula, e nos surge como "produto de uma raça, de uma terra, de um clima e das condições de vida de um povo". Cabo Verde sem a morna ficaria descaracterizado (Ibidem, p. 178).

Faz-se necessário, por isto, determo-nos um pouco mais nos fundamentos estabelecidos por estudiosos, críticos e conhecedores da cultura de Cabo Verde sobre este importante elo de identificação cultural crioula. Desta forma, tentaremos compreender a morna a partir de seu surgimento, remontando à sua origem, para mais adiante partir para uma análise literária de suas linhas temáticas mais comuns.

$\mathrm{Na}$ verdade, as origens da morna não constituem ponto pacífico entre os pesquisadores: a maior dificuldade para o estabelecimento de uma história da morna, mais precisa e embasada, consiste na quase ausência de informações acompanhadas de uma sistemática falta de documentos comprobatórios. Vasco Martins afirma que “[...] as fontes de informação são essencialmente orais, muita coisa se perdeu, a memória humana é imprevisível, e separar o trigo do joio é uma tarefa insegura e flutuante" (1988, p. 9).

É de se ressaltar que, ao longo da história, muito já foi dito e escrito acerca da origem da morna, complexa e controversa, como também observa Russel Hamilton:

a cultura musical popular figurava, juntamente com a língua crioula, como um emblema e uma manifestação da originalidade caboverdiana $^{27}$. Deste modo, a morna é tão identificável com Cabo Verde como o samba com o Brasil. E a origem da morna, como canto, música instrumental e dança, tem provocado debates e controvérsias à sua procedência (1984, p. 109).

Hamilton, enfatizando que, em português, o adjetivo morno significa "tépido, agradável", acrescenta que Jean-Paul Sarrautte, por exemplo, considera que "a morna é

\footnotetext{
${ }^{27}$ As grafias "caboverdiano" / "caboverdiana", "caboverdeano", "caboverdianidade" ocorrem em citações e títulos neste texto. Daí a oscilação gráfica.
} 
exclusivamente portuguesa nas suas origens musicais" (Ibidem), hipótese refutada por vários estudiosos, principalmente, cabo-verdianos. Manuel Ferreira, por exemplo, ressalta o caráter simplista deste argumento, esclarecendo que a morna (que data de 1765, mais ou menos) é mais antiga que o fado e que este originou-se no Brasil e daí foi levado para Portugal pela corte de D. João VI no primeiro quartel do século XIX, transformando-se em fado-canção em meados daquele século (FERREIRA, 1985, p. 185). José Alves dos Reis complementa que "não é fácil encontrar no folclore português ou outro estrangeiro qualquer das características das formas musicais das mornas"; e corrobora B. Léza (1936-1957): "há só uma terra que conhece a Morna e só um povo que conhece-lhe os versos - é Cabo verde e o Cabo-verdeano [...] porque só ele compreende... porque só a ele é dado conhecer, sentir, interpretar, a alma de sua terra" ${ }^{\text {28. }}$.

Voltando à hipótese fundamentada no adjetivo morno, o musicólogo e compositor do final do século XIX José Bernardo Alfama vislumbra nele a origem da palavra "morna", conforme esclarecem Moacyr Rodrigues e Isabel Lobo, caboverdianos que trouxeram grande contribuição para a compreensão daquela modalidade poético-musical com a obra A morna na literatura tradicional: fonte para estudo histórico-literário e a sua repercussão na sociedade, publicada em Cabo Verde no ano de 1996. Rodrigues e Lobo afirmam que:

Quase um século se completou desde que pela primeira vez se ventilou a questão das origens e características da morna. Cabo Verde vivia então um período em que proliferaram os primeiros artigos de homens saídos de uma formação acurada, de um ambiente cultural dinâmico de euforia e afirmação política dos ideais republicanos. É em 1910 que José Bernardo Alfama salienta o morno sabor da morna. Desde essa data para cá o assunto não tem saído de cena (1996, p. 11).

Ainda no bojo dessa polêmica sobre a origem da morna, Manuel Ferreira coloca sob suspeita a hipótese de Gilberto Freyre e de Archibald Lyall sobre a origem antilhana (1985, p. 176) e emenda declarando que Archibald fez essa suposição por pensar ser a palavra introduzida por marinheiros franceses, "dada a possível semelhança entre 'as pequenas canções nostálgicas a que os mestiços da Martinica chamariam mornes' e 'as canções da Boavista de Cabo Verde" (Ibidem).

Outra linha de pesquisa encontra analogias com o termo francês morne que, como adjetivo, significa "sombrio", "taciturno", "lúgubre", e, como substantivo,

\footnotetext{
${ }^{28}$ Reis e B. Léza apud LIMA, 2001, 244.
} 
designa um monte, sentido que costuma ser empregado nas Antilhas e que, vindo para Cabo Verde, poderia por extensão designar a música dos escravos refugiados nas colinas; mas o fato de não ter perdurado para a morna contemporânea nenhum significado geográfico inviabiliza também esta hipótese.

Para Luís Romano, a morna derivaria da chanson morne - canção triste cantada por escravos nas Antilhas francesas e levada para o arquipélago cabo-verdiano por marinheiros da África. Romano "fixa o fim do século XIX como o período em que a morna se originou e sublinha os seus elementos não africanos, como as suas qualidades melódicas e o uso de instrumentos de corda europeus (ROMANO, 1984, p. 109).

Benilde Caniato, em seu texto Morna - expressão do lirismo cabo-verdiano, acrescenta a seguinte informação sobre o surgimento da morna:

Sabe-se que no século XIX a morna já era cantada e dançada no Arquipélago. E por seu caráter dolente e nostálgico, é possível que tenha recebido alguma influência dos lamentos árabes marroquinos. $\mathrm{Ou}$, então, segundo Luís Romano, teria sido "gerada pela melancolia que humanamente prevaleceu nos núcleos dos primeiros elementos, que chegaram do Reino (2005, p. 73).

Outros especialistas, que reintegram a modalidade musical na história cruzada dos Estados Unidos e de Cabo Verde, ou da Inglaterra e de Cabo Verde, opinam que "morna" deriva do termo inglês mourning: "lamentar-se, queixar-se".

Acalorando o debate sobre a polêmica origem da morna em virtude de uma falta de documentação e fundamentação históricas, houve quem buscasse dar-lhe uma gênese mítica, como o poeta Pedro Cardoso. Observemos o seu poema “A Morna"29,".

Flor de duas raças tristes

Vindas da Selva e do Mar

Que a sós se acharam um dia

Na mesma praia ao luar!

A Morna, verbo ou cantiga, A quem saiba sentir, Trava ao gosto dôce-amargo

De delícias punir...

A morna quem a inventou

Foi um poeta de Aquém Mar,

Numa tarde rôxa e amena

\footnotetext{
${ }^{29}$ Poema de Pedro Cardoso transcrito de O Eco de Cabo Verde, 22, Praia, junho de 1934, por Semedo, 2006, p. 91. Grifos nossos.
} 
Ouvindo a onda murmurar.

$\mathrm{Na}$ sua morna cadência

Canta a mágoa e a alegria.

Dos éstos da Alma Crioula

E a rubra sinfonia...
A Morna é a flôr mais linda
Do canteiro Hesperitano!
Pelo amor das Jardineiras
Fez-se a Rosa de todo o ano.
Pelo ritmo em ameno encanto
E o primor das cantigas;
Desponta e floresce em beijos
$\mathrm{Na}$ bôca das raparigas.
Voa da Volúpia exalando-se
Em requebros aliciantes
Como a da Sirena outrora
Tentando os nossos mareantes!
A Morna nasceu de um beijo
De cálidas vibrações
Numa só fundindo as almas
De uma Bárbara e um Camões!

Cardoso funda a origem da morna no mito hesperitano, que considerava as ilhas cabo-verdianas como representação das Hésperides, imagem colhida na Biblioteca Clássica do Liceu de São Nicolau.

Manuel Lopes, no conto "Um galo que cantou na baía", 1936, fornece-nos, por sua vez, uma versão alegórica do nascimento da morna (com apoio de outra imagem clássica, a da deusa Vênus) na ilha da Boavista: a melodia teria sido gerada dos sons que o remar dos pescadores produzia - a cadência do remo na forqueta. Assim, segundo argumento que Manuel Lopes, pela boca do Guarda-Tói, diz ter colhido do relato dos mais velhos, teria a morna suas sementes na toada dos pescadores boavistenses, com função lúdica intimamente ligada à atividade laboral, à semelhança das cantigas de trabalho. Esta é uma hipótese levantada, com base na leitura lítero-alegórica do conto de Manuel Lopes, por António Germano Lima (2001, p. 242).

Para o maestro Alves dos Reis, a morna

nasceu do povo que a criou, banhando-a com as lágrimas das suas mortificações, resignações e sofrimentos, e [...] essas melodias não são outra coisa senão a exaltação ou o queixume eterno da alma caboverdiana, no que ela tem de mais comovente, de mais extravagante e de mais tumultuoso (REIS, 1984, p. 9). 
António Germano Lima, a esta interpretação da morna como tradução de sentimentos relacionados à temática da dor, ainda acrescenta:

A morna é, portanto, um dos patrimônios espirituais que simbolizam a resistência passiva do povo cabo-verdiano, desde a resistência dos seus antepassados para a conquista e afirmação da sua identidade até à luta contra as condições de uma vida agreste de um passado recente. Em síntese, é o canto saído da luta do povo das Ilhas para a sua própria sobrevivência.

Assim, originado desta força anímica, o canto-dança morna é uma forma de expressão tão forte que através dela todo o povo das ilhas, lá onde estiver, mais rapidamente se identifica (LIMA, 2001, p. 241).

$\mathrm{Na}$ tentativa de traçar uma história da origem da morna, o musicólogo Vasco Martins aponta a maior dificuldade encontrada pelos pesquisadores:

teve uma origem e influências sem dúvida. Para a compreendermos melhor, será necessário dobrar os tempos, mesmo sendo os documentos históricos, pode-se dizer, inexistentes ou muito raros. Se os há, talvez estejam numa cave poeirenta, para sempre misturados com velhos papéis, o que dificultou bastante este traçar da história da Morna (1989, p. 17).

Mesmo com todas as limitações, esta busca tem sido empreendida. Vasco Martins nos dá os detalhes de como ela tem se processado de forma assistemática no seio da sociedade cabo-verdiana, afirmando:

Foi essencialmente feito[a] com entrevistas com homens antigos, que ainda seguem a tradição oral das coisas existentes, com certos parágrafos escritos sem grandes provas estruturais evidentes, com imaginação, com longas conversas entre os homens mais cultos das ilhas, com a análise de artigos de jornais, com a fantasia delirante de certos interlocutores, enfim, com pequenas coisas que afugentariam o mais modesto musicólogo (Ibidem).

Seja qual for a origem, para Russel Hamilton, "todas as palavras sugerem a lentidão, a tibieza e a dolência da morna no ritmo e melodia, no sentimentalismo nostálgico da letra das canções tradicionais e no modo dos pares dançarem agarradinhos, movendo-se em cadências dolentes" (1984, p. 110).

As discordâncias evidentes entre os estudiosos quanto à origem do termo "morna", e com relação às origens do fado (que recebeu influências mouras ao passar por um antigo bairro árabe de Lisboa, a Mouraria), do samba e da morna reacendem questões teóricas e políticas. 
Pesquisadores cabo-verdianos especializados no estudo da morna como Vasco Martins, Moacyr Rodrigues e Isabel Lobo atribuem o seu nascimento, como forma máxima da expressão musical de Cabo Verde, a um complexo processo. Segundo eles, a morna, base da nacionalidade cabo-verdiana, que reflete a sensibilidade do povo e o sentimento coletivo do arquipélago, é uma música viajante, gerada de um tronco comum que compartilha com o fado português e o samba brasileiro. A raiz destas três formas de expressão musical é o lundum africano, originário de Angola, do qual ainda persiste uma derivação, o lundu, na ilha da Boavista. O lundum africano se assemelhava, por sua vez, com o batuque, que sempre esteve presente na ilha de Santiago.

O lundum ${ }^{30}$ foi introduzido na Ilha da Boavista em finais do século XVII, e logo continuaria a sua viagem, seguindo as rotas da escravidão, até o Brasil. Naquela ilha cabo-verdiana, segundo a hipótese de Vasco Martins, de maneira simultânea ainda que independente -, sofreu o impacto do samba e do fado, numa lenta metamorfose até se converter na morna.

O maestro Martins acrescenta ainda que:

A Morna, forma de música cabo-verdiana, é essencialmente uma temática sensitiva e elegante, dramatização das aspirações e do conceito do imaginário do povo cabo-verdiano, uma temática popular e tradicional muito própria e de grande valor universal $(1989$, p. 10).

De acordo com um estudo antropológico das raízes das manifestações culturais cabo-verdianas, levado a cabo por Gabriel Mariano em seu Cultura caboverdeana: ensaios (1991), o maestro, compositor e poeta Vasco Martins (1993, pp. 34-38) busca na mestiçagem a origem da morna. Ressalta ele que do cruzamento das culturas africana, européia e sul-americana se originará uma música popular rica em Cabo Verde, destacando-se "a morna nostálgica da Boavista, com seus acordes sincréticos (originários da modinha brasileira cruzada com lundum, fado, samba, fox-trot e mambo)", como principal modalidade identitária cabo-verdiana reconhecida hoje no panorama mundial.

Para o poeta Eugénio Tavares, contudo, deve ressaltar-se deste compósito, na morna autóctone da ilha da Boavista enquanto “criação étnica, saída fundamentalmente

\footnotetext{
30 Alguns acreditam também que o lundum foi levado a Lisboa pelos africanos, que eram muito numerosos na capital portuguesa no final do século XVII, antes de partir para o Brasil e Cabo Verde, constituindo, portanto, o provável filão musical originário do fado.
} 
do substrato cultural de origem afro-negra presente na Ilha da Boavista" (Apud LIMA, 2001, p. 246), a sua componente africana; ou seja, oriunda dos cantos e danças dos grupos étnicos afro-negros. Eugénio Tavares, pois, com base na sua vivência e em pesquisas da tradição oral na ilha de Santiago, corrobora o argumento de que, se Santiago é o berço da nacionalidade, suas manifestações culturais constituem a base para a criação cultural das demais ilhas.

Com efeito, se atentarmos para a ordem de ocupação geomorfológica do espaço do Arquipélago de Cabo Verde - numa primeira fase, ilha de Santiago a partir de 1461-1462 (em 1533 a Ribeira Grande, hoje Cidade Velha, era a capital do ultramar português), logo em seguida ilha do Fogo e a partir do final do século XVI ilhas da Boavista, S. Nicolau e Santo Antão (cerca de 140 anos depois da ilha de Santiago) poderemos compreender melhor a migração das formas afro-negras de Santiago para a Boavista, acompanhando o caminho percorrido das antigas finason do batuque santiaguense até as formas boavistenses da morna ${ }^{31}$.

Cabe esclarecer que uma intensa ligação marítima entre as ilhas, no passado, favoreceu a interpenetração cultural que permitiu aquela migração de formas.

António Germano Lima destaca a ligação étnico-histórico-cultural que "une umbilicalmente o boavistense ao santiaguense no primeiro século da ocupação dos espaços da Boavista" (LIMA, 2001, p. 248). Segundo o pesquisador, "terá existido uma fase da morna primordial na ilha da Boavista de forte influência afro-negra, à base de queixumes e lamentações provocados pela dor escrava" (ibidem, p. 249), com função sublimadora ou de autodefesa psicossocial contra condições infra-humanas a que eram submetidos (LIMA, 2001, p. 256) os negros escravizados. Para o colono, este cantodança era genericamente denominado "batuque" (ou "infernal barulheira"), enquanto que, para o negro, ele era diferenciado em modalidades como "cateco", "gondon" e "pembera"32. Na maioria das vezes, certos conteúdos que subjaziam as queixas, lamentações e queixumes derivados da condição escrava eram imperceptíveis ao colonizador. Os cantos dos colonos, marcados pelo sistema político-religioso que caracterizou os séculos XVI e XVII, carregavam-se de gravidade, tristeza e melancolia e não eram permitidos aos escravos.

\footnotetext{
${ }^{31}$ A ilha Brava foi povoada graças à erupção do vulcão da ilha do Fogo em 1675 e finalmente as ilhas do Sal e de S. Vicente foram povoadas, respectivamente, em 1834 e 1840 (LIMA, 2001, pp. 247-248).

${ }^{32}$ Conferir CÂMARA CASCUDO, 1972, p. 150.
} 
Este contraste de visões das manifestações afro-negras - muitas vezes para fins espirituais e sagrados na perspectiva dos escravos, ao passo que profanas e luxuriosas na perspectiva do colono - acabava por gerar uma discriminação das formas de expressão escrava no jogo colonizador/colonizado.

A relação entre canto, poética e ritmo de origem africana provindos do batuque santiaguense terá propiciado, mais tarde, em contato com o ambiente geomorfológico da ilha da Boavista, uma nova forma melódica ou protótipo da morna (cf. GONÇALVES, 2006, p. 88), que, progressivamente, transformou-se na expressão máxima da alma cabo-verdiana que hoje conhecemos.

Poderíamos questionar, então: por que a morna não nasceu na ilha de Santiago? Esclarece Lima que, em primeiro lugar, a geomorfologia plana da ilha da Boavista (ao contrário da geomorfologia acidentada da ilha de Santiago, que opunha obstáculos ao intercâmbio entre os seus núcleos populacionais) facilitou a síntese necessária à eclosão das lamentações e queixumes dos expatriados submetidos ao regime escravocrata. Por outro lado, as repressões do colono às expressões negras na ilha de Santiago eram mais duras, o que travava sensivelmente o aspecto sincrético que, segundo Vasco Martins, subsidiaria a constituição estrutural mestiça da morna, como produto misto do cruzamento das culturas africana, européia e sul-americana.

Nos dias de hoje, as lamentações e queixumes da morna persistem e vale a pena, em outro momento ou em estudo mais verticalizado, tentar estabelecer suas relações com os cantos de trapiches da ilha de Santo Antão e as bombenas da ilha Brava, considerados por Augusto Casimiro ${ }^{33}$ como saudade da selva longínqua, da África natal, dor de exílio, mágoa de nostalgia, amargura, desterro, saudade. No caso da produção dos emigrados, a morna-saudade terá tido a função de suavizar a dor da saudade (LIMA, 2001, p. 256), sentimento básico de ligação do ser humano à terra-mãe.

Cabe ressalvar ainda que, embora alguns pesquisadores defendam que a morna originária, criação da Boavista, seria fundamentalmente satírica e caricatural, não devemos esquecer que a morna lírica (morna-amor, morna-saudade, morna-gratidão) também era produzida naquela ilha, viveiro de uma multiplicidade de estilos que permitiu o amadurecimento de linhas, funções e estruturas que culminaram na morna contemporânea, marca indiscutível da identidade cultural cabo-verdiana.

\footnotetext{
${ }^{33}$ Citado por Oswaldo Osório, Cantigas de trabalho, 1980, pp. 33-34.
} 


\section{2 - Diferenças entre a morna da Boavista e a da Brava: a contribuição de Eugénio Tavares}

Um estudo comparativo seria utilíssimo para a diferença sistemática dos diversos contornos melódicos das mornas das Ilhas.

João Lopes Filho

Em se tratando de uma forma de expressão que caracteriza o modo de estar cabo-verdiano, pode-se equivocadamente encarar a morna apenas como uma manifestação popular. Todavia, Manuel Ferreira nos informa que:

[...] a morna, embora uma expressão artística criada numa sociedade dividida em classes, não será apenas (ou somente?) uma criação tipicamente popular, porquanto todas as classes ou estratos sociais do Arquipélago se lhe entregam, a amam, com ela se enternecem, vibram, choram e sonham - e eis o nódulo da questão: os seus criadores se recrutam em qualquer delas; as mornas oriundas da burguesia são tão cabo-verdianas como as mornas oriundas do povo; [...] não é, no sentido puro da expressão, uma arte popular porque dela, na criação e no desfrute lúdico, participa por igual, o povo inteiro (1985, p. 189).

Coube a Eugénio Tavares, nas primeiras décadas do século XX, dar ao ritmo musical e ao texto poético da morna um status culto, estendendo-a de manifestação das classes populares às classes média e alta da sociedade cabo-verdiana: a morna torna-se patrimônio de todas as ilhas e de todos os cabo-verdianos. Eugénio, desta forma, transforma-se num dos responsáveis direto pelo casamento entre a música e a poesia oriundas da tradição popular e a série literária cabo-verdiana que começava a canonizarse. Instituída como forma musical inextrincavelmente identificada com uma nostalgia cabo-verdiana impregnada do peso do colonialismo, na época em que produziu sua obra, a morna de Eugénio atingiu todas as classes sociais e, como discurso literário, representou a expressão de uma elite cultural mestiça que ansiava por representar a alma cabo-verdiana, como destacava Pedro Cardoso: "Traduzindo a alegria e a dor da nossa raça / Em ritmo polariza a Alma caboverdiana" (CARDOSO, 1933, p. 64).

Com a publicação de Mornas - cantigas crioulas, em 1932, Eugénio Tavares daria uma preciosa contribuição para o estudo das origens da morna, bem como da sua adaptação à paisagem humana das diferentes ilhas. No prefácio à edição, Eugénio afirma que a morna nasceu na ilha da Boavista e acrescenta: 
Na Boa Vista, não se elevou na linha sentimental; antes, planou baixo, rebuscando os ridículos de cada drama de amor; cantando o perfil caricatural de cada episódio grotesco; ironizando fracassos amorosos; sublinhando a comédia gentílica das moias (naufrágios de navios tão frequientes nas costas da ilha), tudo no estilo leve e arrebicado que a afeiçoa a vida despreocupada do povo boavistense, o mais alegre e o mais amorável de entre as gentes do Arquipélago; música elegante, psicatada de sorrisos finos e de harmonias ligeiras (TMCC, 1969, p. 17).

Esclarece Jean-Yves Loude, em seu estilo coloquial à moda de um contador de estórias, a relação da morna com a ilha em que nasceu:

- Nós viemos aqui buscar uma história. Aqui está o começo.

[...]. O padre observa o cargueiro encalhado, o guitarrista anónimo e a moldura de violinos.

- Não tenho dificuldade em traduzir esta imagem - anuncia ele. - Boa Vista é, simultaneamente, um reputado cemitério de barcos e a terra natal da morna, a música que se tornou célebre em todo o mundo graças a artistas como Titina, Bana, Celina Pereira e a diva Cesária Évora. Encontrarão facilmente o navio naufragado, pois o Cabo Santa Maria não pára de agonizar numa praia deserta ao norte da ilha. Quanto à morna, ainda ninguém conseguiu descobrir a sua origem. [...] Com efeito, a morna terá tido um inventor ou será o produto da efervescência de uma dada época? Seria preciso esquadrilhar a memória da ilha, sondar as fachadas de Sal Rei que testemunham uma sociedade abastada e, ao mesmo tempo, raspar a crosta da salina até recordar o labor dos apanhadores de sal. Se quiserem aproximar-se do espírito da morna, deverão atravessar as pastagens vazias do interior, aceder às aldeias afastadas do Norte, encontrar os vestígios dos portos desaparecidos. Mas saibam que não foi por acaso que nasceu em Boa Vista. Estavam reunidas todas as condições...

A frase em suspenso subentende uma parte escondida que nos cabe a nós deslindar.

- É uma investigação muito vasta para uma semana - previne o padre -, pois aquilo que procuram é a alma do país. A morna comprometeuse de tal forma com o povo do arquipélago que a procura das suas origens parece estar inscrita em todos os cabo-verdianos (1999, pp. 20-21).

Loude complementa as modalidades que Eugénio Tavares destacava na ilha da Boavista, ressaltando ainda como temática da morna primordial canções que choram partida, que deploram o imobilismo ou buscam o ridículo das dores de amor, aliando um lado nostálgico ou pleno de desgosto a um caráter caricato ou grotesco. 
Sobre o desenvolvimento da morna na ilha Brava, Loude destaca-lhe o caráter romântico. Na ilha de São Vicente, a morna transforma-se em modalidade sentimental, geralmente destinada à execução por pares enlaçados ${ }^{34}$.

Assim resume o estudioso a metamorfose da morna de ilha para ilha:

Quando a morna passou de Boa Vista para Brava, foi tomada de languidez. Talvez tenham sido o nosso clima, as brumas, as nossas flores, que acalmaram o nosso sangue? Depois, ao chegar a São Vicente, reduziu-se a um balancear, a uma dança quase imóvel, propicia aos beijos e aos murmúrios sensuais (Ibidem, pp. 133-134).

$\mathrm{Na}$ Boavista, a morna era, a princípio, mais festiva, divertida, rápida e caricata, (provavelmente cumprindo um papel como o da finason do batuque, de reguladora de comportamentos sociais frente aos costumes tradicionalmente praticados pela comunidade), embora mornas-queixume-lamentação também tenham sido produzidas como "melopéia com que a raça cativa amenizava as agruras do exílio forçado" (CARDOSO, Folclore caboverdiano, 1982, p. 19). Partindo destes "protótipos" boavistenses, logo a morna se fez mais melancólica e lenta na Brava, sob o impacto, por exemplo, da música da ilha da Madeira. A morna se transformou ao som dos travessados, os ritmos de baile dos Estados Unidos, e também adquiriu seu sentido crítico em São Vicente, o lar da coladeira, sua parente mais agitada e satírica. José Alves dos Reis e Baltasar Lopes concluem que, mesmo metamorfoseando-se de ilha para ilha de acordo com aspectos psicossociais, muitas das mornas de compositores bravenses e sãovicentinos possuem raízes em antigas mornas da Boavista, ou seja, a técnica boavistense permanece ainda operante nas canções das outras ilhas, ora nos ritmos ligeiros, ora pela contribuição das cantadeiras vindas da Boavista (como, por exemplo, Joana Maninha, compositora residente em S. Vicente) $)^{35}$.

António Germano Lima acredita que a morna-saudade é uma recriação bravense da morna da Boavista trazida pela marinheiragem boavistense ${ }^{36}$, que dominava a navegação interilhas. Com o incremento da emigração de habitantes da Brava para os Estados Unidos da América, um elemento acentua-se nas mornas: a

\footnotetext{
${ }^{34}$ Não esqueçamos, contudo, que a morna boavistense levou também para S. Vicente o estilo satírico da morna, juntamente com as cantadeiras-compositoras Salibânia e Joana Maninha, que vieram da Boavista para S. Vicente entre 1880 e 1890.

${ }^{35}$ Apud LIMA, 2001, p. 245.

${ }^{36}$ Ressalte-se que, dentre a marinheiragem boavistense, havia grande quantidade de escravos por volta de 1750. A pesca da baleia em mares cabo-verdianos, nos navios americanos, acabou por levar grande quantidade de islenos a emigrar.
} 
saudade, transformando estruturalmente a morna da Boavista em morna-saudade e morna-amor da Brava (por volta de 1855), sendo seu maior cultor Eugénio Tavares.

No que toca à interpretação, inicialmente, era cantada e composta por mulheres: era a chamada pré-morna; em seguida, por homens, em bares ou nos bordéis, carinhosamente chamados lugares de pássa sabe (de "vida alegre").

Segundo Moacyr Rodrigues, as mornas, inicialmente, eram interpretadas por mulheres do povo, consideradas de "má vida". Na verdade, estas primeiras cantigas remontam às finason (herança africana) ou cantos improvisados produzidos pelas finadeiras no batuque, provavelmente levados da ilha de Santiago para Boavista: "A morna desenvolveu-se em meios femininos" (RODRIGUES, 1986).

Para Carlos Filipe Gonçalves, há referências históricas a "um batuque chamado morna”, o que poderá indicar que num determinado momento, batuque e morna se confundiam (2006, p. 82) e ainda reforçar uma linha escravocrata da gênese da morna (Ibidem, p. 89).

Do terreiro (origem popular) de batuque ao salão (aspectos aristicratizantes), novos instrumentos foram sendo adicionados à execução das mornas, como o piano, os violões e o acordeão.

Sobre a relação morna/violão, faz-se necessário, mais uma vez, citarmos Vasco Martins, visto que:

é muito provável que a morna, tal como se conhece, tivesse nascido com a radicação do violão em Cabo Verde, fenómeno mais ou menos espontâneo e objectivo.

Mesmo que as origens sejam, em princípio, e por falta de provas científicas, nubladas, foi com certeza com o violão ou a guitarra portuguesa ou com um instrumento polifónico que a morna se produziu a si mesma, isto é, conquistando as suas particularidades sobretudo harmónicas (1988, p. 20).

Em "Echoes of Cape Verdean Identity: Literature and Music in the Archipelago 37", Simone Caputo Gomes esclarece que: "To trace the history of the morna is a complex task, one that has occupied musicians, intellectuals and all Cape Verdeans alike ${ }^{38, '}(2003$, p. 270). Neste mesmo artigo, a pesquisadora brasileira procura

\footnotetext{
${ }^{37}$ Ecos da Identidade Cabo-Verdiana: Literatura e Música no Arquipélago.

${ }^{38}$ "Traçar a história da morna é tarefa complexa, que tem envolvido músicos, intelectuais e o caboverdiano mais humilde". A versão do texto em português, ainda inédita, foi-nos cedida gentilmente pela autora.
} 
mostrar também como a morna é representada sob a ótica e as vivências femininas, relacionando a "pré-morna" produzida pelas kantaderas-compositoras à visão da morna moderna, transposta para a literatura. Em suas palavras, a morna:

[...] goes beyond the ecstasy of creation and contemplation. It is deeply rooted, as Dina Salústio's narrative tells us, in the "esconderijos privados" ["private hiding-places"] of Creole society; it exposes hypocrisy and extreme situations, it brings into the open those feelings fed by the waves of the sea and the screams of the night, it helps to create a space for a social conscience, education and struggle $^{39}$ (Ibidem, p. 280).

Percebe-se, deste modo, que Gomes aponta, pioneiramente, a necessidade de se levar em consideração esta nova perspectiva, uma vez que até a publicação de seu artigo não havia estudos que evidenciassem este ponto de vista. Refere, ainda, a pesquisadora que a "morna preliminar", como a denomina Vasco Martins, era executada por uma solista mulher (primeira voz) acompanhada por um coro de mulheres (segunda voz ou grupo de baxon), o que reforça a relação da morna com a expressão feminina e com a estrutura do batuque (finadeira e grupo de percussão/segunda voz).

A evolução da morna, portanto, iniciou-se no canto de mulheres, conheceu o virtuosismo instrumental e abriu asas nas danças de salão.

No que diz respeito às mudanças técnicas produzidas nesta modalidade musical, por volta de 1800, juntamente com o aparecimento dos instrumentos de corda em Cabo Verde, ressaltam-se significativas marcas da presença da música brasileira. B. Léza introduziu na morna de S. Vicente o meio-tom, rompendo com o andamento tradicional da morna boavistense e bravense, entrecortando-o com pausas e suspensão, técnica da música brasileira da época (samba e modinha). Todavia, foi preciso aguardar até o século XIX para que a morna despontasse como autêntica forma musical.

Alguns autores referem que, nas formas originárias da ilha da Boavista, a morna não chega a apresentar o conteúdo dramático que se faz conhecer popularmente por meio da difusão feita por compositores e intérpretes da qualidade de Eugénio Tavares - na Ilha Brava - ou de Francisco Xavier da Cruz, popularmente conhecido por B. Léza. Com efeito, músicos e poetas dessas ilhas começam a imprimir-lhe um ritmo

\footnotetext{
39،“...] ultrapassa o êxtase criativo e contemplativo. Mergulha, qual a narrativa de Dina Salústio, nos "esconderijos privados" da sociedade crioula, denunciando hipocrisias e situações-limite, expondo sentimentos alimentados pelas ondas e pelos gritos das noites, ajudando a construir um espaço de conscientização, pedagogia e luta".
} 
mais lento que o originário, dotando-a de uma cadência em quatro tempos, de caráter nostálgico, sentimental e melancólico.

Para Jean-Yves Loude (1999, pp. 125-126), Eugénio Tavares foi o grande poeta romântico cabo-verdiano, um homem galante que cantava as mornas que compunha para realizar suas conquistas e comprazia-se em ser o centro das atenções de uma platéia feminina que apreciava uma composição que acabava de nascer. Segundo o pesquisador, Nhô Eugénio imprimiu à morna da Boavista languidez e melancolia, além de extrair toda a potencialidade poética da língua crioula.

Sobre a temática da morna na ilha dos hibiscos, sua ilha natal, Eugénio complementa:

na ilha Brava, a terra em que os homens casam com o mar [...] a dulcíssima estância da saudade, mercê da vida aventureira e trágica do seu povo, a morna fixou os olhos no mar e no espaço azul, e adquiriu essa linha sentimental, essa doçura harmoniosa que caracteriza as canções bravenses. Elevou-se de riso a pronto, e afinou, amorosamente, pelo portuguesíssimo diapasão da saudade (TMCC, p. 18).

Envolto por esta atmosfera ora repleta de momentos felizes ora pontuada por carências das mais diversas ordens o poeta da ilha das flores compôs mornas que se eternizaram com a ajuda e a força das gerações que o sucederam.

\section{3 - A obra mornística de Eugénio Tavares}

O estilo musical e poético da Morna de Eugénio Tavares saiu da Brava e teve influência em todo o arquipélago.

Carlos Filipe Gonçalves

O ano de 1932 pode ser considerado decisivo no que concerne à evolução da morna no cenário cultural e, especialmente, literário cabo-verdiano. Mornas - cantigas crioulas, de Eugénio Tavares e Uma partícula da lira caboverdeana, de Francisco Xavier da Cruz (B. Léza) vêm à estampa, mudando temas, processos e formas de expressão mornísticas.

Para Moacyr Rodrigues e Isabel Lobo, a obra de Eugénio representa 
um apreciável contributo ao estudo das origens da morna e sua adaptação às feições psíquicas de cada povo das ilhas. Pela primeira vez se afirma a origem cabo-verdiana da morna e se tenta esboçar o percurso desta pelas várias ilhas no que diz respeito às mudanças que vai sofrendo na sua migração entre ilhas. É ainda desta publicação o Post-fácio de José Osório de Oliveira que a caracteriza tendo como fundo os elementos vários extra-literários e literários, por vezes, (temática e forma) considerando-a uma poesia ignorada (1996, p. 11).

Luís Manuel de Sousa Peixeira, na obra Da mestiçagem à caboverdianidade: registos de uma sociocultura (2003), observa:

Em 1933, Eugénio Tavares, em "Mornas [e] Cantigas Crioulas", traria um contributo precioso para o estudo das origens da morna e da sua adaptação às feições psíquicas do povo das diferentes ilhas; assim se afirmava a origem caboverdiana da morna e se tentava traçar o seu percurso pelo Arquipélago (2003, p. 171).

E acrescenta:

A Morna decorre dos traços culturais do homem caboverdiano", já que, como expressão musical do povo, nela se verifica a simbiose dos elementos mais díspares que caracterizam a alma crioula. Francisco Xavier da Cruz, vulgarizado e eternizado como B. Lèza, relaciona as características líricas e satíricas da morna com o contexto caboverdiano, no que toca à sua criação; relacionando assim a ligação música, dança e poesia como contributo das três ilhas que a terão formado: Boavista, Brava, São Vicente (Ibidem).

Assim, a mensagem-poesia (texto escrito a partir da oralidade) da morna é indissociável da música, expressa em canto e dança. António Germano Lima encara a morna como:

um subsistema cultural de representações simbólicas do modo de vida do povo que a criou, representações essas que se realizam através da musica, poesia, gesto e coreografia [...] canto-dança em compasso quaternário e em tom de queixumes e lamentações plangentes, soluçantes, vagarosos, dolentes, melancólicos, enternecedores... (2001, p. 240).

Sobre a obra de B. Léza, acima citada, Moacyr Rodrigues e Isabel Lobo complementam que é a partir desta que:

se adianta uma definição da morna em termos do foro literário, tais como as suas características líricas e satíricas e a íntima ligação ao contexto cabo-verdiano no que toca à sua criação, realçando a ligação música, poesia e dança como contributos das três ilhas que a 
formaram: Boavista, Brava e S. Vicente. Esta definição, clara e precisa quanto ao que respeita à morna como texto, sofre aqui e ali por motivos da escrita escolhida, escrita essa da época, meio romantizada - de um excessivo nacionalismo (1996, p. 12).

Quanto ao aspecto textual da morna, Moacyr Rodrigues e Isabel Lobo esclarecem:

Morna é um texto (composição de dança, música, poesia) com funções narrativas, líricas, descritivas e satíricas, em que se combinam formas de expressão como o diálogo, o monólogo, a reflexão e o comentário, em manifestações directas e indirectas (1996, p. 31).

É de se levar em conta também o que Luís Peixeira nos informa acerca do caráter narrativo que cedo se imprime à morna.

A Morna conta histórias, descreve paisagens e estados de alma,
satiriza condutas. Daí que a narrativa, predominantemente
melancólica e nostálgica, se volte para o amor, para a separação da
"mãe" e para a "crecheu". A estes temas poderá estar associada a partida, a
solidão, a tristeza, bem como o reencontro e a alegria (2003, pp. 171-172).

Quanto à sua tipologia, Moacyr Rodrigues e Isabel Lobo identificam dois grandes grupos de mornas: narrativo descritivo com fins líricos ou dramáticos e narrativo-descritivo com fins satíricos. Ressaltam ainda que "ambos os grupos buscam objectivos comuns, mais gerais, como sejam os ideológico-políticos e os pedagógicodidácticos" (1996, pp. 21-22).

Por sua vez, quanto à natureza, os pesquisadores advertem que a morna é um texto em que, a par de suas funções narrativas, descritivas, líricas, dramáticas ou satíricas, combinam-se formas de expressão como o diálogo, o monólogo, a reflexão e o comentário (Ibidem, p. 31).

No que diz respeito à dança, faceta performática da morna que não se deve deixar de levar em consideração, Luís Peixeira acrescenta: [...] "a Morna é partilhada por todos os grupos sociais, independentemente das respectivas origens ou condições econômicas, dançada tanto no funco ${ }^{40}$ como no sobrado" (Ibidem, p. 173).

$\mathrm{O}$ autor afirma, ainda, que devido à morna acompanhar o cabo-verdiano ao longo de toda a sua existência, ela "torna-se complementar dos ritos de passagem: do nascimento; do casamento; da morte, tocada ao violino numa última despedida,

\footnotetext{
${ }^{40}$ Casa humilde, outrora circular e coberta de palha. Palhota.
} 
enquanto o corpo baixa à sepultura" (Ibidem). Exemplo emblemático deste ritual é a morna "Hora de bai", composta por Eugénio Tavares.

A morna alcança sua grandeza durante os anos de 1930: os brasileiros que faziam escala em São Vicente desembarcaram na ilha também as entonações do sambacanção com estruturas mais refinadas e elaboradas. Cabo Verde contava então com um compositor excepcional, atento às tendências musicais contemporâneas: Francisco Xavier da Cruz (1905-1958), o B. Léza, que imprimiu à morna um caráter mais moderno. B. Léza foi aluno de Luís Rendall (1898-1958), um faroleiro e virtuose do violão, que havia aprendido a tocá-lo com um brasileiro. Rendall foi o tutor de B. Léza e deixou numerosas composições musicais, sendo várias impactadas pelo choro brasileiro, um gênero semi-erudito no qual as notas, muito adornadas, navegam pelas linhas de um baixo contínuo.

No tempo de B. Léza ${ }^{41}$, Mindelo vivia um período de plena modernidade. A Sociedade Tipográfica e Publicidade edita ali um jornal mensal, Notícias de Cabo Verde, regionalista e independente, e publica as mornas e os opúsculos de Francisco Xavier da Cruz.

Nesta época de grande efervescência econômica e cultural, a elite de Mindelo freqüentava o cinema Éden Park para apreciar os recitais de piano, nos quais não faltavam as obras de Chopin, Puccini ou Wagner. Os intelectuais e artistas da Claridade dão uma visão literária à revolta dos pobres, às greves na companhia de carvão, etc., e as mornas e as coladeiras se transformam em pequenos sketchs da vida cotidiana. Durante os anos 20 e 30, São Vicente não padece nem de fome nem de seca. Conta, além disso, com a proteção do governador de Cabo Verde, Amadeu Gomes de Figueiredo, patrono e grande amante da arte e da música, a quem B. Léza dedica uma de suas mais belas mornas, Noite de Mindelo, em 1938.

Com relação aos temas, tanto B. Léza quanto Eugénio, além de outros compositores de mornas, geralmente aludem tanto a situações da vida cotidiana de seus protagonistas como a acontecimentos relacionados à política, nunca se esquecendo da emigração forçada de milhares de trabalhadores cabo-verdianos para as Ilhas de São Tomé e Príncipe, para Angola e Moçambique. Assim, o mornista vai trazer às suas

\footnotetext{
${ }^{41}$ Sobre este tópico consultar a obra da jornalista Gláucia Nogueira, O tempo de B. Léza: documentos e memórias (2005).
} 
composições sucessos e costumes urbanos, ressaltando as alterações e os dramas experimentados na vida real.

Com efeito, é possível verificar que a morna acompanha a história de Cabo Verde a partir dos círculos populares, enquanto que os mais bem posicionados economicamente inclinavam, de início, sua preferência para modalidades mais elaboradas como a música erudita vinda da metrópole. Foram, paulatinamente, porém, totalmente conquistados pela morna.

Retomando o escritor e crítico literário português Manuel Ferreira, vemos que é “na morna, que não 'possui equivalente em português', considerada nos seus três elementos (poesia, música e dança), que o Cabo-Verdiano encontra o pólo por excelência do seu génio artístico. Nela encontra todas as possibilidades de escape emocional e todos os caminhos do sonho e da fantasia" (FERREIRA, 1985, p. 90). Uma morna, bem composta, virá sempre impregnada de elementos como "morabeza" ${ }^{42 \text { " e }}$ "cretcheu ${ }^{43}$,, levando o cabo-verdiano a criar, a um só tempo, sugestões emocionantes, seja dançando-a nos populares "bailes nacionais", seja nos bailes em que prevalecem as camadas mais privilegiadas financeiramente. Em momentos assim, o homem crioulo faz com que sua alma se realize na sua mais alta completitude.

\section{4 - A Morna Amorosa de Eugénio Tavares}

Terra di morna, di lua cheia, Terra di Eugénio e serenata, Qui mar tá cantá junto d'areia.

Ess qu'ê nha terra, Nhor Deus qui dá'm Ca tem más sabe na mundo inteiro Di sol más quente, di luar más brando

Gabriel Mariano

A partir do momento em que foram publicadas em livro, as mornas de Eugénio Tavares passaram a constituir uma fonte para a compreensão da história do povo cabo-

\footnotetext{
${ }^{42}$ Palavra crioula que significa hospitalidade, afabilidade, amorabilidade, solidariedade, receber bem as pessoas.

${ }^{43}$ Amor, pessoa amada.
} 
verdiano. Os elementos das mornas nascem da vontade do poeta de expressar as marcas identitárias que unem os habitantes do arquipélago e os cabo-verdianos na diáspora.

O poema popular, a coreografia e a melodia são os três elementos fundamentais da morna, como já mencionamos anteriormente. A poesia e a musicalidade dos versos trazem à tona os sentimentos do fundo da alma do povo, e às vezes, denúncias de momentos dramáticos da vida social. Neste sentido, a morna configura-se como uma das formas de tradução da alma do povo cabo-verdiano: é a manifestação da voz da sua alegria, da sua dor, da sua incerteza ou da sua esperança. Produto da simbiose de elementos díspares que caracterizam a alma crioula (o lírico e o satírico, por exemplo), a morna é, ao mesmo tempo conservadora, porque permite a continuidade da tradição, e maleável, porque se adapta plasticamente às circunstâncias de sua produção.

Para Luís Manuel de Sousa Peixeira:

A Morna é, com efeito, a manifestação mais abrangente da identidade caboverdiana, sobretudo quando utiliza o crioulo. Assume "aspectos coletivos" ao ilustrar a saga do caboverdiano, desde a origem, consubstanciada no seu encontro com o europeu, em circunstâncias históricas únicas. Assume "aspectos particulares" de acordo com as feições de determinadas ilhas. Nestas, adquire aspectos individuais em razão do sofrimento de cada ser, frente a vivências únicas e pessoais, quanto ao amor, à separação, a carências de ordem material, à luta pela sobrevivência (2003, p. 172).

Neste tópico, trataremos particularmente da temática do amor nas composições de Eugénio Tavares, originariamente compostas em língua crioula. Cada morna-poema será acompanhada de sua tradução para a língua portuguesa, no sentido de permitir ao leitor a maior compreensão e fruição da estética de Eugénio, revolucionária porque, em pleno colonialismo, concede ao crioulo um estatuto de língua literária.

Eugénio Tavares é o poeta do amor e da emigração bravense: o lirismo amoroso e o "terra-longismo" (das viagens para a América, da pesca da baleia) são linhas de força de sua obra poética.

O amor "cretcheu" pode ser cantado nos seus aspectos serenos e nos ambientes serenos da ilha ou nos aspectos de inquietação, fonte das mais belas mornas de todos os tempos com as quais a alma cabo-verdiana se identifica. $\mathrm{O}$ amor, na obra de Eugénio, é buscado de forma exaltada, em plenitude, permitindo a comunhão entre amador e amada e, ao mesmo tempo, trilhar um caminho para o divino (Deus). 
Desta forma, o amor para Eugénio Tavares apresenta-se em plano abstrato. $\mathrm{O}$ poeta identifica o amor com um sentimento sacralizado e o "cretcheu" com a manifestação concreta de um amor total, sensualmente vivido (conferir Peixeira, 2003, p. 183).

O primeiro texto da coletânea Mornas - cantigas crioulas já nos aponta caminhos para a abordagem do fenômeno amoroso na poética de Eugénio Tavares:

\section{Morna de Aguada}

Se é pam vivé na es mal

De ca tem

Quem que q'rem,

Ma'n q're morré sem luz

Na nha cruz,

$\mathrm{Na}$ es dor

De dâ nha bida

Na martirio de amor!

Amá, s é pam morré,

Pam dixâ,

Ai, quem que'n q're,

(Pa oto gente bem q'ré!)

Ma'n q'ré vivé na es martirio!

Se é pa es tristeza de q'ré

Sem esperança,

Sem fé,

Ma'n q'ré destino de bai,

De morré,

De esquicê

Num momento de amor,

Uma bida intero de dor! (TMCC, p. 33).

\section{Morna de Aguada}

Se é para viver com esse mal

De não ter

Alguém que me queira

Quero morrer sem luz

$\mathrm{Na}$ minha cruz,

Com essa dor

De dar a minha vida

Ao martírio do amor!

Amar, se é para morrer,

Para deixar,

$\mathrm{Ai}$, a pessoa que quero,

(para outra pessoa querer)

Quero é viver nesse martírio!

Ao invés dessa tristeza de querer

Sem esperança,

Sem fé,

Quero o destino de ir,

De morrer,

De esquecer

Num momento de amor,

Uma vida inteira de dor!

$\mathrm{Na}$ "Morna de aguada", o eu lírico canta e lamenta o amor, mas não o amor por alguém em especial: o amor pelo amor é o tema do poema. Eugénio Travares procura retratar a dor do ser humano que, porque ama, sofre. O campo semântico relacionado é o da solidão, da morte, da tristeza, um outro núcleo de base das mornas - o da "amorabilidade" ou a "morabeza" - como aponta Manuel Ferreira em A aventura crioula (1985, p. 188)

A primeira parte desta morna já apresenta um ser em conflito, imerso no pavor de que sua capacidade de amar não seja correspondida: "Se é para viver com esse mal/ De não ter/ Alguém que me queira,/ Quero morrer sem luz". Em linguagem simples, própria de uma estética que se quer contígua à oralidade, o texto deixa entrever um espírito inquieto, em fuga lírica da realidade e, sobretudo, em busca incessante pela 
pessoa que o amará. Como última saída, e se o eu lírico puder escolher, ficará com a morte, fim de uma vida vazia e inútil se nela não existir o amor.

O sujeito poético, em contradição ("morrer" / "viver") é arrebatado pelo devaneio de amar, única razão para a vida. Embora amar sem correspondência seja sinônimo de morte, é preferível viver em martírio a perder a pessoa amada para outro querer. Com a expressão desse dilema, o poeta retoma uma linha temática universal da angústia de amar, já tão fecunda também na literatura de língua portuguesa.

A postura romântica observada nesta morna leva o poeta a retomar um tópico recorrente na lírica amorosa: a díade amor/dor, só que imprimindo-lhe uma ambigüidade rentável para o aspecto filosófico associado ao sentimento amoroso. Examinemos o poema por partes.

Na primeira estrofe, a dor pode corresponder ao martírio de não ser amado:

Se é para viver com esse mal

De não ter

Alguém que me queira

Quero morrer sem luz

Na minha cruz,

Com essa dor

De dar a minha vida

Ao martírio do amor!

Na segunda estrofe, morrer de amor (a dor de amor) apresenta-se como solução para o caso de abandono:

\footnotetext{
Amar, se é para morrer,

Para deixar,

$\mathrm{Ai}$, a pessoa que quero, (para outra pessoa querer)

Quero é viver nesse martírio!
}

Na última estrofe, um instante de amor redime uma vida inteira de dor:

Ao invés dessa tristeza de querer

Sem esperança,

Sem fé,

Quero o destino de ir,

De morrer,

De esquecer

Num momento de amor,

Uma vida inteira de dor! 
O tempo verbal utilizado no poema, sempre presente, sugere uma linha de continuidade entre essas variáveis do sentimento amoroso, ou seja, Eugénio parece propor, assim como Camões num dos seus mais famosos sonetos ${ }^{44}$, as metamorfoses provocadas pelas contradições do amor naquele que ama.

Eugénio Tavares se dizia grande admirador de Luís de Camões e o pesquisador António Germano Lima esclarece que, na ilha Brava, "a morna receberá, com Eugénio Tavares, forte influência, não só das tonalidades e melodias do fado, mas também da poética lírica do romantismo camoniano" (2001, p. 244). Na morna "Amor é carga? Amor é culpa?", que mais adiante examinaremos, ecos de Camões nas suas proposições paradoxais de definição do amor poderão ser escutadas. Mas Eugénio não trabalha por antíteses. O que há é uma compreensão do amor, de suas qualidades tensas e complementares. O amor é carga grande, mas não é pecado; traz preocupações, mas ilumina a vida... Todavia, sem amor correspondido, a vida converte-se em dor:

\section{Vida sem bo luz...}

Vida sem bo amor,

É dor!

Dixam morré mi só, Morré de amor pa bó, Morré pa bó de amor, Oh Flor!

Pa que'n q're vivé só Sem bó?

Ai, pertam na bo peto,

Amor,

$\mathrm{Na}$ sombra de bo ojo preto.

Pa'n cré 'ma Deus estâ na Ceu,

$\mathrm{Na}$ ceu,

Na tempo, amá na bonança,

Bo al xa'n nes nha esperança

De inda do ser de meu,

Ante'n morré de dor,

Amor! (TMCC, p. 55).

\section{A Vida sem tua luz...}

A vida sem o teu amor,

É dor!

Deixa-me morrer sozinho,

Morrer de amor por ti,

Morrer por ti de amor,

Ó flor!

Para que vou querer viver só

Sem ti?

$\mathrm{Ai}$, aperta-me no teu peito,

Amor,

Na sombra dos teus olhos pretos.

Para que eu acredite que Deus está no céu,

No céu,

No tempo, na bonança,

Deixa-me com minha esperança

De ainda seres minha,

Até que eu morra de dor,

Amor!

\footnotetext{
${ }^{44}$ Amor é um fogo que arde sem se ver,/ é ferida que dói, e não se sente;/ é um contentamento descontente,/e dor que desatina sem doer.// É um não querer mais que bem querer;/ é um andar solitário entre a gente;/é um nunca contentar-se de contente;/ é um cuidar que ganha em se perder.// É querer estar preso por vontade;/ é servir a quem vence, o vencedor;/ é ter com quem nos mata, lealdade.// Mas como causar pode seu favor/ nos corações humanos amizade,/ se tão contrário a si é o mesmo Amor?

(CAMÕ̃ES, Luís de. Poesia lírica. Seleção e introdução por Isabel Pascoal. Queluz: Biblioteca Ulisseia de Autores Portugueses, 1984, p. 82).
} 
Por outro lado, amor e dor, céu e inferno, podem conjugar-se num único momento, "Se tão contrário a si é o mesmo Amor". A morna "Contam nha crecheu" levará à Graça da comunhão com o ser amado, mesmo que esta lhe proporcione dores futuras (prazer ou dor, grifos nossos):

\section{Contam nha crecheu}

Contam, nha crecheu, Pâ que banda é Ceu; Amá pamode el ta abri, Quando'n spiabo do arri.

\section{Ai, Ceu é Paz,}

Ceu é graça, Garça de amor!

Ou co prazer, ou co dor,

Ceu morâ na bo ragáz...

Ceu estâ na bo peto,

Na go ojo preto...

Quando no estâ nos dos só,

No estâ na ceu mi co bó... (TMCC, p. 40).

\section{Conta-me, meu amor}

Conta-me, meu amor, Para que lado é o céu; Ama para ele abrir, Quando te olho, tu sorris.

Ai, Céu é Paz,

Céu é graça, Graça de amor! Com prazer, ou com dor,

O céu mora no teu colo...

O céu está perto de ti,

Nos teus olhos pretos...

Quando estamos juntos, sozinhos

Estamos no céu, eu e tu...

Ampliando o âmbito da experiência de aproximação do poema anterior, a morna "Cantiga que Deus ensinam", continua apregoando a aproximação da mulher amada, associando ao núcleo prazer/dor ou céu/inferno, o núcleo festa/morte.

\section{Cantiga que Deus ensinam}

Encosta cabeça

Na nha peto, Amor:

Pâ que tanto pressa

De corrê pá dor?

Xa'n bejado testa

Pa'n clariâ nha sorte:

Ai, se um bejo é festa,

Bejo cheu é morte...

Ó bejo de amor,

Bejo de crecheu!

Seja comâ for,

Es bo inferno é ceu...

Ó Sol da'n bo asa,

Pa'n largâ es degredo!

Nha destino é feto

De tristeza e dôr.

\section{Cantiga que Deus ensina}

Encosta a cabeça

No meu peito, Amor:

Para que tanta pressa

De correr para a dor?

Deixa-me beijar a tua testa

Para clarear a minha sorte:

Ai, se um beijo significa festa,

Muitos beijos significam morte...

Ó beijo de amor,

Beijo de bem-querer!

Seja como for,

O teu inferno é o céu...

Ó sol me dê a sua asa,

Para que eu deixe esse degredo!

Meu destino é feito

De tristeza e dor. 
Lei de Deus já flâ:

"Santo é quem que cré".

Tudo graça estâ

$\mathrm{Na}$ esperâ co fé.

Trigueirinha santa,

Dormi na ragáz:

Nha dos braço é manta,

Es nha sombra é paz.

Encostâ, crecheu,

Cabeça na es peto:

Deus ja dam es geto

De morâ na ceu...

Bem obi es clamor

Que Deus ensinam

Pam ta lebia dor

De otos coraçam.

No bencê es distancia,

No embarcâ na bento;

No largâ nos ânsia

Co nos sofrimento... (TMCC, p. 57).
Lei de Deus já disse:

"Santo é quem quer".

Toda a graça está

$\mathrm{Na}$ esperança com fé.

Trigueirinha santa,

Dorme no colo:

Meus braços são o cobertor,

E minha sombra é a paz.

Encosta, bem-querer,

A cabeça nesse peito:

Deus já deu um jeitinho

De eu morar no céu...

Vem escutar esse pedido

Que Deus me ensinou

Para aliviar a dor

De outros corações.

Vamos vencer essa distância,

Vamos viajar ao vento;

Vamos deixar essa ânsia

Com o nosso sofrimento...

Ao céu do colo da amada, quando juntos, cenário do primeiro poema, acrescenta-se neste o beijo na testa, muitos beijos, a cabeça encostada no peito, o dormir no colo, em tempo verbal imperativo - encosta, deixa-me beijar, dorme, encosta, vem escutar. Na última quadra, o eu lírico incita a amada a vencer a distância e viajar ao vento, ou seja, "morar no céu" significa estar em comunhão concreta com o ser amado. Adiante desenvolveremos este aspecto da concepção amorosa das mornas de Eugénio Tavares, analisando-o segundo a perspectiva de Gabriel Mariano (1991).

Segundo Moacyr Rodrigues e Isabel Lobo, tanto a morna de Eugénio quanto a de B. Léza:

revelam a afectividade, o carinho e o apreço que se tem pela mulher, nessa fase, na sociedade cabo-verdiana. Revelam uma certa sensibilidade quase feminina da própria poesia. [...] a poesia de Eugénio é mais filosófica, interrogando-se sobre os problemas do amor, superdivinizando-o, mas não deixando, contudo, de ser um amor objectivo. [...] (1996, p. 69).

Para Gabriel Mariano, o Amor é a principal linha de força da poesia de Eugénio Tavares. O poeta é "sem dúvida um grande místico do amor, exalta, enaltece e chega a divinizar o amor com uma intensidade visível à primeira leitura" (1991, p. 126). 
O convívio amoroso transmuta-se num caminho de salvação, concepção algumas vezes imbuída de religiosidade. Examinemos uma das mais conhecidas mornas de Eugénio Tavares:

\section{Força de Crecheu ${ }^{45}$}

Ca tem nada na es bida

Más grande que amor.

Se Deus ca tem medida, Amor inda é maior...

Amor inda é maior, Maior que mar, que ceu: Mas, entre otos crecheu, De meu inda é maior.

Crecheu más sabe, É quel que é de meu. El é que é sabe Que abrim nha ceu... Crecheu mas sabe É quel

Que q'rem...

Se ja'n perdel,

Morte ja bem...

Ó força de crecheu,

Abri'n nha asa em flor!

Deixa'n alcança ceu

Pa'n bá oja Nós Senhor,

Pa'n bá pedil semente

De amor coma es de meu,

Pa'n bem da todo gente,

Pa todo conché ceu! (TMCC, p. 34).

\section{Força do Amor}

Não há nada nessa vida

Maior que o amor

Se Deus não tem medida, Amor ainda é maior...

Amor ainda é maior, Maior que o mar, que o céu: Mas entre outros amores, $\mathrm{O}$ meu ainda é maior

Bem-querer mais gostoso, É aquele que me pertence

Ele é que é a chave

Que abriu o meu céu...

Bem-querer mais gostoso

É aquele

Que me quer...

Se eu o perder,

A morte chega...

Ó força do amor

Abre as minhas asas em flor!

E deixa-me alcançar o céu

Para ir ver o Nosso Senhor,

Para que eu lhe peça semente

De amor como o meu,

Para que possa dar a todos,

Para que todos possam conhecer o céu!

Não esquecendo de valorizar toda a arquitetura estética do poema em crioulo como esta morna bem o demonstra, com seus paralelismos, rimas externas e internas, aliterações, assonâncias - podemos observar a vocação sacralizante do amor, ora como veículo, ora como condição para se aproximar da divindade:
Ó força do amor
Abre as minhas asas em flor!
E deixa-me alcançar o céu
Para ir ver o Nosso Senhor,

\footnotetext{
${ }^{45}$ Informa o editor do portal da Fundação Eugénio Tavares que esta morna foi inspirada na história de amor de Hermano de Pina e Ana de Barros: "Hermano de Pina regressava à Brava, sua terra natal, após a licenciatura em Medicina. Um dia cruzou-se com uma senhora, bravense de rara beleza, que o deixou fascinado. Do fascínio a uma grande paixão foi um sonho muito bonito. Da paixão ao grande amor da sua vida, foi outro sonho bonito". Disponível em: http://www.eugeniotavares.org/docs/pt/obra/mornas.html Acesso em maio de 2010.
} 
Em “Força de Crecheu”, podemos considerar o 'amor' como força universal que une irmãos, ou tudo o que se ama sobrepujando o amor carnal de macho e fêmea e alcançando uma outra dimensão mais ampla.

$\mathrm{Na}$ morna-poema acima, pode-se observar o tópico que Manuel Ferreira denomina de "amorabilidade" ou o conceito de "morna-amor". Nesse caso, o amor não se apresenta somente como tema, mas também como forma de expressão. "Força de cretcheu", não trataria apenas de aspectos individuais, mas da própria condição humana.

O paralelismo que estrutura o poema, de forma lógica atribui ao amor força maior que a energia divina: "Se Deus não tem medida/ Amor ainda é maior..."/ "Maior que o mar, que o céu". O amor expresso pelo sujeito poético busca um processo de ampliação, para estender-se a tudo e a todos.

Vasco Martins complementa que:

Eugénio Tavares deve ter sido um dos primeiros mornistas a tratar o amor de forma quase sistematizada. Gabriel Mariano, na separata das comunicações do I Encontro de Poesia de Vila Viçosa, estudou brilhantemente o platônico amor de Eugénio e, como diz, é com Eugénio que "os amantes não se dissolvem no seio da divindade. Viajam para o céu, enxergam a face de Deus, mas nenhum deixa de ser um, os dois não deixam de ser dois, para o Amor e no Amor". [...] De facto, o extremo romantismo de Eugénio e o talento na escritura do crioulo em poesia pura juntaram-se na Morna para formar uma poderosa mensagem da canção que não foi igualada no seu conjunto. A noção de Amor em Eugénio Tavares justifica, é claro, uma época romântica, uma estrutura poética condizente com os estados espirituais também do próprio poeta, que se diz possuir pela mulher uma paixão sensível (1988, p. 87).

Este imaginar o Amor como transcendência, eterniza o valor dado ao querer, ao gostar, ao desejar, ao ato de amar, veiculando a idéia de que o Amor é libertador e torna o amante-amado um ser superior.

Cabe ressaltar que o desenvolvimento do poema continua enfatizando aquele núcleo já citado do sentimento amoroso como paradoxal. Vejamos: se o Amor é maior que Deus, o fato de o sujeito poético pedir ao Divino Ser sementes de amor para distribuir a todos, para que possam também conhecer o céu, constitui uma contradição. Bastava solicitá-lo à força do amor, assim como pediu que abrisse suas asas em flor. Se o Amor é maior que Deus, Este conseqüentemente não poderia proporcionar algo maior que Ele mesmo. Como sintetiza poeticamente Gabriel Mariano, "Magnífica heresia; 
viril confrontação. O Amor absorve a própria divindade. Claridade solar. Meio-dia em Cabo Verde" (1991, p. 134).

Em analogia, entendemos que o céu é a representação de todo o bem existente no Universo, e com essa distribuição do amor, a Vida e Graça estariam ao alcance de todos. Os apelos do poeta enternecem os que se vêem representados em "Força de cretcheu", elevando-se o valor humano. O desejo de atingir a dimensão de amar e ser amado, não acontece somente para o eu lírico, mas para todos, num diálogo de anseio do bem, numa intimidade que se projeta sobre o outro, seja amante ou amigo.

Todavia, na morna "Amor é carga? Amor é culpa", uma idéia insistente (a de que Deus fez o amor), que dialoga em contraponto com a expressa em "Força de cretcheu", acrescenta-se a uma busca de definição do amor.

\section{Amor é carga? Amor é Culpa?}

Amor é carga?

É carga grande, má el câ pesado! É culpa fundo, má el câ pecado!...

Deus que fazel, el câ condenal! É Deus, nós Pai, el é que tempral... É Deus, é Deus que fazé Amor, El ca fazel pa botâ cachor...

Amor é culpa?

Má el câ pecado, el câ perdição,

Pamode é escada de salbação...

Ami, de meu, jâ erguem nha bida... Ami, de meu, jâ limpam nha Céu... Se el é nha culpa, el ca nha pecado; Se el dam cudado, el lumiam nha bida... (TMCC, p. 37).

\section{Amor é carga? Amor é culpa?}

Amor é carga?

É carga grande, mas não é pesado! É culpa grande, mas não é pecado!...

Deus é que o fez, e ele não o condenou! Foi Deus o nosso pai, foi ele que o temperou... Foi Deus, foi Deus quem fez o Amor, Ele não o fez para ser comida de cães...

Amor é culpa?

Mas ele não é pecado, nem perdição,

Porque ele é a escada da salvação...

A mim, o meu já ergueu a minha vida...

A mim, o meu já limpou o meu céu...

Se ele é a minha culpa, não é o meu pecado;

Se ele traz preocupações, ilumina a minha vida...

A reiteração dos verbos "fez", "foi” e a repetição da palavra "Deus" concedem ao ser supremo a responsabilidade da criação do mais profundo sentimento humano.

No ensaio "Amor e partida na poesia crioula de Eugénio Tavares ou inquietação amorosa", o escritor e ensaísta cabo-verdiano Gabriel Mariano tratará dos dois temas mais glosados pela obra poética eugeniana. No que toca à lírica amorosa, Mariano enfatiza na poética de Eugénio Tavares a questão da realização ou da manifestação do amor, estabelecendo analogias com o platonismo amoroso. Para Gabriel Mariano, em "Força de cretcheu" duas palavras se contrapõem: "amor" e 
"cretcheu": "o vocábulo cretcheu significa aquela mulher a quem amamos e que nos ama a nós, o que implica, portanto, dois aspectos: a existência actual da mulher e a reciprocidade no amor" (1991, p. 129).

$\mathrm{O}$ andamento do poema, que insiste até o sexto verso na palavra amor, passa de um plano impessoal para uma via concreta de manifestação do amor quando introduz a "cretcheu”. Interroga o ensaísta: "não haverá aqui algo de parecido com o platonismo amoroso?" (ibidem).

O próprio Gabriel Mariano responde à questão proposta:

Curiosamente, não há em Eugénio a divinização ou a espiritualização da mulher, como acontece em grandes místicos do amor, como Camões, Dante ou Petrarca. [...] Não se espiritualiza o Amor, mas a mulher. E, se a acaso o Amor surge espiritualizado, é em virtude de a mulher amada ser "Raio da Divina Formosura" como diz Camões.

Com Eugénio passa-se o inverso: nele o que é espiritualizado é o amor. Melhor dito: o diálogo amoroso. [...] O que ele exalta é o amar e ser amado.

Segundo António Sérgio, na lírica de Camões o amor é anterior ao objecto amado e independente do objecto amado.

Em Eugénio, o amor não é anterior à mulher amada, é contemporâneo. E, ao contrário de Camões, Eugénio não concebe o amor como algo independente da mulher amada. Em Eugénio, o amor manifesta-se com e na mulher que ele ama e que o ama a ele (1991, pp. 132-133).

Continuando a acompanhar a linha de tentativa de definição do amor pela via interrogativa, a morna "Que importa'n lâ?" recolhe fios já disseminados pelos poemas anteriormente examinados como a Graça, o Céu, Deus, a relação amor/dor como caminho de salvação, acrescentando-lhes outras problemáticas:

\section{Que importa'n lâ?}

Se é pa'n perde es luz de amor, Es graça, es ar de quem que'n q'ré, Ma'n q're curtí ses otos dor: Perde nha luz, perde nhá fé.

'N ca perdi: Nhor des que dâ: Quem que al negâ graça de ceu? Se Deus da'n el, el é de meu; Se el é de meu, nha xa'n cantâ!

Se é pa'n ganhâ reno de ceu Que ta salba'n alma de mal, Na'n q're vivê co nha crecheu, Pa el ca engana'n, pa'n ca enganal...

\section{Que me importa?}

Se for para eu perder essa luz do amor, Essa graça, esse ar de quem me quer, Quero curtir as suas dores:

Perder a minha luz, perder a minha fé.

Eu não pedi: Senhor Deus é que deu: A quem ele negou uma graça do céu? Se Deus me deu essa graça, ela é minha; Se ela é minha, me deixem cantar!

Se é para eu ganhar o reino do céu Que vai salvar a minha alma do mal, Quero viver com a minha amada Para que ela não me engane e eu também não minta para ela... 
Que importa'n lâ que mundo flâ, Se el ja el q're'n, se mi ja'n q'rel? Se'n perdê Deus, 'n ca perdel Que importa'n lâ? Que importa'n lâ?

Sê pa da'n oro, ou pa da'n prata, Se é pa da'n luz, se é pa da'n paz, Ma'n q're casâ co nha Ingrata, Ma'n q're dormi na sê ragaz... (TMCC, p. 36).
De nada me importa o que o mundo fala

Se eu a quero e ela também me quer?

Se eu perder Deus, eu não a perco;

Que me importa? Que me importa?

Se for para me ofereceres ouro ou prata, Se for para me ofereceres luz ou paz, Eu prefiro casar com a minha ingrata, Eu quero dormir no seu colo...

Relembrando a estrutura temática paradoxal apresentada em "Força de cretcheu", esta morna, construída com base na inquietude interrogativa e pautada pela anáfora da conjunção condicional ("Se") vai reapresentar o núcleo Amor/Deus da seguinte forma: a luz do amor é uma graça dada por Deus, escada para o reino dos céus; porém, uma vez alcançada, pode-se perder Deus, a fé, mas não o amor. Não há bem maior do que dormir no colo da amada, mesmo que, ingrata, engane o amante.

Esclarecem Moacyr Rodrigues e Isabel Lobo que:

Para Eugénio é preferível viver na graça do amor, mesmo se tiver que perder a salvação. Para um certo tipo de conceito religioso, preconceito (?), esta atitude seria uma blasfémia. Mas não se toca num poeta que é o orgulho de um povo. Além disso, mal se saíra da Monarquia e se estava apenas no início da implantação da República, com toda a sua irreverência anti-clerical, sem se cair na irreligiosidade (1996, p. 70).

Seguindo trilhas já traçadas por Gabriel Mariano no seu ensaio sobre o amor na obra de Eugénio, constatamos que a mesma mulher que, no convívio amoroso conduz ao céu, porque não é divinizada como nas líricas de Camões e Petrarca, pode apresentar, em contexto cabo-verdiano, características negativas que a aproximam mais de uma mulher real.

O núcleo de mornas que apresentaremos a seguir explicita essa leitura.

\section{Enganosa}

Pa que nha ta espiam,

Se quel que ojo de nha ta prometem

Nha ca ta podé dam?

Co um mom nha mostram céu, Co que oto nha abrim porta de inferno: Ma mi, si mé'n crecheu.

Ja 'n purda nha es maldade, Té ja'n pedi nhor Des pa purda 'n el

\section{Enganosa}

Porque me olhas,

Se aquilo que os teus olhos me prometem Não vais conseguir me oferecer?

Com uma mão tu me mostraste o céu, Com a outra tu me abriste a porta do inferno: Se eu for bem-querido

Já perdurei nesta maldade,

Até já pedi ao Nosso Deus que ma perdure 
Na mundo de Berdade.

Mas, se nha ca ta da 'n

Todo que ojo de nha estâ prometem,

Pa que nha ta espiam? (TMCC, p. 52).
No mundo da verdade.

Mas se tu não me deres

Tudo o que teus olhos me prometem,

Porque que me olhas?

A mulher "enganosa" é interrogada pelo sujeito poético na medida em que o seu comportamento promete e nega, abre as portas ora do céu, ora do inferno, poder contraditório já atribuído ao amor nos poemas em que Eugénio Tavares busca defini-lo. Aqui, o "Mal de amor" é personificado na mulher que engana ou, mais adiante n'“Aquela pessoa..." que devolve o eu lírico do céu à terra, em queda livre:

\section{Quel pessoa...}

Note tem treba,

Ca mas sucuro que sê ojo.

Junho tem neba,

El ca mas albo que sê corpo.

Maior zimola,

Ca chegâ graça de sê boca;

Se Deus da'n el

Me'n dal nha bida, ami'n ganha na troca...

Quando el arri,

Nhor Des ta abri

Porta de Ceu; sol ta escobri,

Mar ta cantâ,

Flor ta esdrobâ.

Mas se el bachâ,

Bachâ sê ojo

Razoado de ago, Nhor Des ta mandâ

Tristeza, nojo,

Tromenta, guerra,

De ceus a terra (TMCC, p. 56).

\section{Aquela pessoa...}

A noite tem trevas,

Não é mais escura que os teus olhos.

Junho tem névoa,

Ele não é mais alvo que o teu corpo.

A maior esmola

Não chega à graça de tua boca;

Se Deus ma der

Eu lhe dou minha vida, eu ganho na troca...

Quando ela ri,

Senhor Deus abre

A porta do céu; o sol fica descoberto,

O mar canta,

As flores desabrocham.

Mas se ela baixar,

Baixar seu olhar

Coisas ruins, Deus mandará;

Tristeza, luto,

Tormenta, guerra,

Dos céus para a terra.

Esta mulher de olhos negros ou escuros (uma constante na sua poética), acompanhada sempre de uma condição fundamental para o sujeito poético, explicitada na morna "Enganosa" - "Se eu for bem-querido" -, domina o poema "Quel pessoa..." e assim é descrita: olhos, boca, sorriso, olhar, enfim, corpo. De suas ações resultarão o canto do mar, o desabrochar das flores ou a tristeza, o luto, a tormenta, a guerra. A analogia com o soneto de Camões "Tanto de meu estado me acho incerto" não constituirá aqui uma heresia poética, mas faz jus ao apelido de "Camões cabo-verdiano" atribuído a Eugénio Tavares.

Do veneno dos olhos pretos da mulher bonita não escapa o eu lírico. 


\section{Mujer bonita}

Mujer bonita, pa el dabo gosto Pa el dabo co bo amor, É só depôs de bo dal bo rosto, De bo dal rosto pâ cuspidor. Pa cada bejo el ta dabo um dor! Pa cada estrela de um ilusam, Pa sonhos morto na coraçam, Anos sem conta de amargor...

Ca no fiâ na ses ojo preto Que tem beneno ne ses espiar... Ses feticeras, co ses mal feto, Es tenê mundo juiso no ar... Ca no fiâ na ses fala sabe: Nha fijo, obi, bo tomâ sentido: Mujer é letra que ca entendido; Ses alma é porta que ca tem chabe... (TMCC, p. 59).

\section{Mulher bonita}

Mulher bonita, para te agradar Para te agradar com o seu amor, É só depois de te dar o rosto, De te dar o rosto para cuspir. A cada beijo ela te dá uma dor! Para cada estrela, uma ilusão, Para sonhos mortos no coração, Anos sem contar com amargura...

Não confiemos nos seus olhos pretos Que têm veneno no seu olhar... Feiticeiras com os seus mal feitos, Elas têm o mundo com a cabeça no ar... Não confiemos nas suas conversas gostosas Meu filho, escuta, toma cuidado:

Mulher é letra que não se entende; As suas almas são portas sem chave...

A estrutura antitética da linguagem camoniana é aqui retomada, com a mestria de quem conhece e sabe extrair as virtualidades expressivas da língua crioula: a cada beijo, corresponde uma dor, para cada estrela, uma ilusão. Em resumo, a mulher aqui representada encontra semelhanças com a "Enganosa" anteriormente citada, já que se caracteriza como: feiticeira, não confiável, perigosa. Afinal, universaliza o poeta: "Mujer é letra que ca entendido;/ Ses alma é porta que ca tem chabe... ("Mulher é letra que não se entende;/ As suas almas são portas sem chave...).

Como na morna "Cantiga que Deus ensinam", "Flor de rosera" apresenta uma mulher que, apesar da beleza, pode ferir com seus espinhos. A distância da amada, percebida pelo sujeito poético, conjuga-se com o temor de sua aspereza.

\section{Flor de rosera}

Flor de rosera,

Co es tanto abrojo

Que, dês mansera,

Sâ ta gardabo,

Dixam contabo

Es nha desgosto

De espiâ co ojo,

Enguli co rosto...

Ó rosa, em braza,

Ja bo estâ alto

E mi tam falto

De pena na asa!

\section{Flor de roseira}

Flor de roseira

Mostra-me tanta beleza

Que desse jeito,

Vou te guardar,

Deixa-me contar

Esse meu desgosto

De ver com olhos

E engolir com o rosto...

Ó rosa, em brasa,

Estás distante

Fazendo-me falta

Com penas nas asas 
Que biram tinha

Sorte de amor;

Bô, nha Rainha,

Mi, bo Senhor!

Ó q'ré sem q'redo!

Ja'n tene medo

De pô nha peto

Na bo aspréza!

Es nha tristeza,

' $\mathrm{N}$ ca oja geto

De pol na bento

De esquecimento! (TMCC, p. 48).
Quem me dera ter

Sorte no amor;

$\mathrm{Tu}$, minha rainha,

$\mathrm{Eu}$, o teu senhor!

Ó, querer sem ser querido!

Tenho medo

De por o meu peito

$\mathrm{Na}$ tua aspereza!

Essa minha tristeza,

Eu não vejo maneira

De jogá-la ao vento

Do esquecimento!

Na segunda estrofe do poema, o eu lírico sugere que a mulher, objeto de seu desejo, oferece-se voluptuosa ("Mostra-me tanta beleza"/ "rosa, em brasa"), mas, ao mesmo tempo negaceia a correspondência ("Ó querer sem ser querido"). Ao amante resta a "tristeza", já que a suprema "sorte no amor" - amar e ser amado, "Tu, minha rainha,/ Eu, o teu senhor!" - não lhe parece permitida.

Na morna "Mal de amor", como nos poemas líricos de inspiração romântica, a natureza assume nuances semelhantes e até amplifica o estado psicológico do eu lírico: a noite e a solidão que compõem o cenário fundem-se à desgraça, à dor e à morte equivalentes à falta de reciprocidade amorosa:

\section{Mal de amor}

Note ficha, mi só na caminho, Mi só co Deus, ma co nhá desgraça. Lua na ceu ja negam sê graça; Ja'n perdê fé de alcança nha ninho!

Oh mal da amor,

Ja bo matam!

Oh mal de amor,

Ja bo dixam.

Mi só nes dor,

Dor de ca tem

Alguem que q'rem,

Ai!

Oh mal de amor!

Oh bom de Deus que chigâ na mi, Pega'n na mon bo leba 'n co geto... Leba'n co geto pa'n ca caí, Ca maguam ferida de nha peto...

Ca bo raza'n, c abo da'n dotor, É ca botica que ta cura'n:

\section{Mal de amor}

A noite caiu, e eu sozinho na estrada, Sozinho com Deus, mas com a minha desgraça. A lua no céu já me negou a sua graça;

Já perdi a fé de alcançar meu ninho!

Oh mal de amor,

Tu me mataste!

Oh mal de amor,

Tu me deixaste.

Sozinho com essa dor,

Dor de não ter

Alguém que me queira

Ai!

Oh mal de amor!

Oh coisa de Deus que chegou até mim, Segura a minha mão e leva-me com jeito...

Leva-me com jeito para eu não cair,

Não magoes a ferida do meu peito...

Não me faças rezas, não me leves ao médico, Não é remédio que vai me curar: 
Es mal de amor que sa ta mata'n, Sê cura é morte, ou igual amor... (TMCC, p. 53).
Esse mal de amor que está me matando, A sua cura é a morte, ou igual amor...

Ser amado ("Alguém que me queira") e "alcançar o ninho" são sinônimos da cura possível para o "Mal de amor". A aproximação da mulher amada ("coisa de Deus que chegou até mim,/ Segura a minha mão e leva-me com jeito...”) é o "remédio" ideal buscado pelo sujeito poético. Mas, o encaminhamento proposto pela segunda estrofe do poema, culminando com as curas possíveis sugeridas no último verso, parece reservar um desfecho trágico seja para o amante, seja para o mal de amor: a morte.

Para Luís Peixeira, "Mal de amor canta o amor jovem, exaltado, o amorpaixão. É o amor frágil, quanto impetuoso. O amor que, fenecendo, adoece e mata, a menos que um igual amor se anuncie (2003, p. 184). Se estabelecermos um diálogo com o poema eugeniano homônimo em língua portuguesa, O Mal de Amor (Coroa de espinhos), a contradição dos aspectos vital e letal do amor também lá se configuram.

Para o ensaísta Luís Peixeira, a morna "Mal de amor" se completa com a "Morna de bejiça", que trata da transformação do sentimento amoroso com o passar dos anos e as circunstâncias:

\section{Morna de Bejiça}

Bejiça é um amostra certo Pâ no conta co morte perto: Mas, sol de entardecer de idade, Sol brando é el, sol de sodade.

Sol brando ca ta quemâ Pele de rosto de nha crecheu. Sol brando, el é sol de gosto Pa ta lumiano porta de ceu.

Amor é quel que ama co gosto: Na boca mel, lebe na peto... Amor é mar quando el esta manso: Guemê co gosto, ama na descanço.

Mar manso é quel mar de nadâ, Mar brado é quel mar de matâ: Amor, ai! quando el é mar brado, Se el ca matâ, el ta derrubado...

Amor, depos de um certo idade, Quando el sintâ co companhero, Ninguem câ tâ ergue promero, Sem que to dós mata sodade...

\section{Morna da Velhice}

Velhice é uma amostra certa

Para podermos contar com a morte próxima Mas, sol de entardecer da idade, É um sol brando, um sol de saudade.

Sol brando não queima A pele do rosto do meu bem-querer. O Sol brando é um sol de gosto Para nos iluminar a porta do céu.

Amor é aquele que ama com vontade:

$\mathrm{Na}$ boca mel, leve no peito... Amor é mar, quando ele está manso: Geme com vontade, ama no descanso.

Mar manso é aquele que dá para nadar, Mar agitado é aquele que mata: Amor, ai! Quando ele é mar agitado, Se ele não te matar, ele te derruba...

Amor, depois de uma certa idade, Quando encontra um companheiro Ninguém quer deixá-lo primeiro Sem que os dois matem a saudade... 
Sintâ junto, labantâ junto, Es é que é sabe, es é que é dreto... Sintâ co amor, gosâ co assunto, Coraçam lebe, graça na rosto...

Crecheu é na debagarinho, Na paz, na graça, na getinho: Amor, pâ bo sentil sê gosto, É na sombrinha de sol posto...

Mas, quando el é de barbotón, É sem valor, sem tom nem som... Nha fijo obi, obi um consejo: Amor más doce, é amor de bejo... (TMCC, pp. 38-39).
Sentar juntos, levantar juntos, Isso é que é gostoso, isso é que é bom... Sentar com amor, gozar com os assuntos, Coração leve, alegria no rosto...

Bem-querer é devagarzinho, Na paz, com graça, com jeitinho: Amor, para sentir seu gosto, É na sombra do sol posto...

Mas, quando ele é de barbas grandes, É sem valor, sem tom, nem som...

Meu filho escuta, escuta um conselho: Amor mais doce, é amor de velho...

A "Morna da Velhice" contrapõe ao "Mar agitado", (que mata) da morna "Mal de amor", o mar sereno do "entardecer da idade".

Luís Peixeira, sobre esta morna, esclarece:

Neste poema louva-se o amor de Velhos, feito de serenidade e ternura. Neste amor dá-se a inversão dos conteúdos conceptuais. Por comparação implícita com "Mal de Amor", este é um amor com a suavidade do pôr-do-sol que não queima o rosto da amada. É como um sol brando da saudade, sugerindo a proximidade da morte... Amor de velho não é um mar bravo, é um mar manso... É o amor "de se sentar junto, levantar junto". Cretcheu... é mansinho... para sentir-lhe o gosto, é na sombrinha do sol posto. Amor de velho é um amor que escapou às contingências da degradação física, ao fatalismo dos receios de previsíveis rupturas... amor depois de uma certa idade, quando ele se sentar com o companheiro, ninguém se levanta primeiro sem que todos os dois matem saudades (2003, p. 185).

A suavidade expressa no campo semântico ("lebe", "paz", “doce") e nos diminutivos ("debagarinho", "sombrinha") mimetiza a mansidão do amor serôdio.

Tendo em conta a morna "Mal de amor", Moacyr Rodrigues e Isabel Lobo ressaltam que, Eugénio Tavares, na "Morna de bejiça", opera a ruptura-reformulação do conceito de amor da seguinte forma:

a) A inversão dos conteúdos conceptuais: o conceito de amor de velho não passa pelas figuras da degeneração e de morte (destruição), cabendo estas ao amor jovem (paixão), alterando-se os conceitos tradicionais;

b) A inversão dos conteúdos conceptuais: o valor relativo da adversativa (v. 3) e a crescente importância da estrutura implícita, por antítese da estrutura explícita (Sol brando ca ta quemâ/ Pele de rosto de nha cretcheu vv. 5-6) de modo a desencadear uma outra figura, a ênfase, geradora de significação. (RODRIGUES \& LOBO, 1996, p. 115). 
No mesmo âmbito da "Morna de Bejiça", outro poema aborda o tema do bemquerer (cretcheu) que se afastou enquanto o amante envelhece, deixando-lhe a solidão e a saudade. O "mal de amor", contudo, não consegue destruir totalmente as esperanças do sujeito poemático: ele nunca ficará sozinho, poderá colocar outro alguém na posição de $\operatorname{amado}(\mathrm{a})$ :

\section{Morna de Nha Santa Ana}

Ja'n q'ré ojâ quem que cá tem, Quem que cá tem crecheu na es bida! Pa más tanguido que corpo é, Nos alma é libre, no tem que q'ré!

A mi, de meu, pa nha pesar, Pa mal de todo nha pecado, El prometem nabiu na mar, El manda dam lancha enajado.

El tiram luz que Nhor Dês dam, El dixam sombra de triaçam; El lebam sol dês mocidade, El xam co dor de nha sodade.

Se bo sentil ta bem pa traz, Ó mar, bizam; bizam ó mar, Pa'n ca sintal na nha ragaz; Pa'n po alguem na sê lugar. (TMCC, p. 50).

\section{Morna de Nhá Santa Ana}

Eu quero ver quem não tem, Quem não tem um bem-querer na sua vida! Por mais forte que o corpo seja, A nossa alma é livre, temos que querer!

O meu, para o meu pesar, Para o mal de todo o meu pecado, Ele me prometeu navio no mar, Ele me ofereceu lancha traçada.

Ele tirou a luz que o Senhor Deus me deu, Ele me deixou a sombra;

Ele levou o sol da minha mocidade,

Ele me deixou com a dor de minha saudade.

Se o sentires chegando por trás, Ó mar, avisa-me; avisa-me, ó mar, Para que eu não o sinta no meu colo; Para que eu ponha alguém no seu lugar.

Outra forma de manifestação do amor nas mornas de Eugénio Tavares (e que amplia a tendência expressa no poema anterior) manifesta-se no texto a seguir - a poligamia lírica ${ }^{46}$.

\section{Na cantero de nha peto}

$\mathrm{Na}$ cantero de nha peto

' $\mathrm{N}$ tem um pé de rosera:

Nha roserinha

É que é rainha!

' $\mathrm{N}$ q'rel co todo rospeto;

Amá, de qualquer manera,

' $\mathrm{N}$ al pranta só rosera

Na cantero de nha peto?

Rador de nha rosa santa, 'N tem que tem otos pranta:

\section{No canteiro do meu peito}

No canteiro do meu peito Eu tenho um pé de roseira: Minha roseirinha

É a rainha!

Amo-a com todo o respeito; Mas de qualquer maneira, Hei-de plantar só roseiras No canteiro do meu peito?

Ao redor da minha rosa santa, Eu tenho de ter outras plantas:

\footnotetext{
${ }^{46}$ MARIANO, 1991, p. 130.
} 
Carinhas preta

Coma violeta;

Chinelinhas cor de prata;

Uns branquinha, otos mulata...

'N tem que tem otos pranta

Rador de nha rosa santa... (TMCC, p. 43).
Carinhas pretas

Como violetas;

Chinelinhas cor de prata;

Umas branquinhas, outras mulatas...

Tenho que ter outras plantas

Ao redor de minha rosa santa...

A capacidade de amar várias mulheres, no mesmo espaço e tempo, configurase por meio de um subterfúgio, o "donjuanismo lírico", referido por Gabriel Mariano, que se justifica na imagem central da composição: um canteiro (o peito do eu lírico) em que domina uma rainha (nha roseirinha), mas que opta por cultivar outras plantas (otos pranta/ Rador de nha rosa santa). Para Mariano: "Trata-se de um poema cheio de sugestões metafóricas [...]. Eugénio é o canteiro, claro está. [...]. Não podemos negar delicadezas nem lirismo a esta inquietação poligâmica de Eugénio Tavares ${ }^{47, "}$.

A conquista amorosa também se apresenta como um tema forte das mornas de Nhô Eugénio. O poema que se segue teoriza as estratégias para a abordagem da mulher amada, demonstrando, possivelmente, grande experiência de seu criador neste campo.

\section{É assim que el ta fazedo...}

Se bo encontra co quem que gostabo, Cantal um verso, ca bo tem medo: Se el ca obido, el ca ta sotado... É assim que el ta fazedo...

Bo é sê sombra, ou bem, ou mal! Se el subí ceu, ou se el ba degredo, Bo é sê traz, ai, bo largal: É assim que el ta fazedo...

Se el dabo um gosto, gosal calado, Ficha bo boca, gardal segredo: Quem que cala, ca ganha pecado... É assim que el ta fazedo... (TMCC, p. 49).

\section{É assim que se faz...}

Se encontrares com quem te ama, Canta-lhe um verso, não tenhas medo: Se ele não o escutar, não vai te bater... É assim que se faz...

Tu és a tua sombra, por bem ou por mal! Se ele subir ao céu, ou se for ao inferno, Tu és a retaguarda dele, ai, não o largues: É assim que se faz...

Se ele te der um prazer, goza-o em silêncio, Cala tua boca, e guarda segredo:

Quem se cala, não é pecador... É assim que se faz...

O refrão - "É assim que se faz" traz amador e amada para o mundo real, repelindo o amor-contemplação e celebrando a possibilidade do amor correspondido.

Não há hipótese de um amor platônico para o sujeito poético, há mesmo um horror da unilateralidade, como podemos constatar na morna a seguir:

\footnotetext{
${ }^{47}$ Idem, p. 131.
} 


\section{Carta quem escrebê nha Lina}

Amor que'n q'ré:

Nha Luz, nha fé:

Da'n bo atenção:

Na estâ nos dos?

Obi'n es voz

De coraçam:

'N estâ escrebedo

Pa'n flabo'n q'rebo

Co paz, co calma:

Desde promero

Té derradero

Folgo de nha alma.

Medo que'n tem:

Bo bá de li,

É que tenem

Ca ta sorri.

Pamó, pa mi,

Se é pa'n negado,

Ma'n q'ré es pecado

De ca sorri...

Pamó, pa mi,

Ai, se é pa da'n,

Tornâ toma'n,

Ma'n q'ré dixa'n

Nha "mom si-si",

$\mathrm{Na}$ es tristeza

De ca tem dreto;

Na nha pobreza

De ca ojâ geto

De quenta es peto...

Crecheu que'n q'ré

Co tudo fé:

Medo que'n tem

De "mom si-si",

Ca ta pedi... (TMCC, pp. 60-61).

\section{Carta para nha Lina}

Amor que eu quero:

Minha luz, minha fé

Dá-me a tua atenção:

Estamos só nós dois?

Escuta-me essa voz

Do coração:

Estou te escrevendo

Para te dizer que te quero

Com paz, com calma:

Desde o primeiro

Até o último

Fôlego da minha alma.

O medo que eu tenho:

É tu ires embora,

É o que me faz

Não sorrir.

Porque, para mim,

Se for para eu não ser aceito

Eu quero esse pecado

De não sorrir...

Porque, para mim,

$\mathrm{Ai}$, se é para me dares

Toma de novo,

Mas quero ficar

Com as minhas mãos atadas,

Com essa tristeza

De não ter direito;

A minha pobreza

De não ver jeito

De esquentar esse peito...

Bem-querer que eu quero

Com toda a fé:

$\mathrm{O}$ medo que tenho

De ficar com as mãos atadas,

Não o peço...

À diferença da arte lírico-amorosa de Camões e de Petrarca, a poesia de Eugénio em língua crioula coloca a mulher no mesmo plano do amante e supõe sempre sua correspondência ao sentimento deste. Observemos a morna "Corda de Sacramento":

\section{Corda de Sacramento}

Pom corda na pé co geto, Pa el ca maguam na nha frida:

\section{Corda de Sacramento}

Coloca-me a corda no pé com jeito, Para ela não machucar a minha ferida: 
Dor de frida, ó dor de bida,

Pa el doé mas fundo é na peto...

Pô corda debagarinho,

Pa nha carne câ sangrâ;

Mi, se'n saí de caminho,

' $\mathrm{N}$ al sabé torna entra...

Tomâ, jam dabo nha pé,

Morram el co trinta nó:

Junto co bó, é mi só;

Junto co mi, quem que'n q'ré.

Nos home é comâ candia

Co destino de lumiâ:

Lumiâ de note, de dia,

Enquanto no câ pagâ...

Ó corpo, ó corpo nha escrabo,

Detâ quitinho, calado:

Ó alma, xam consejabo:

Buâ libre, sem cudado!

Es corda de sacramento,

El bem, el ta ba na bento:

Ma, que corda santa de amor,

Só Deus sabé sê valor! (TMCC, pp. 62-63).
Dor de ferida, ó dor de vida,

Para ela doer mais no fundo do peito...

Coloca a corda devagarzinho,

Para a minha carne não sangrar;

Se eu sair do caminho

Saberei entrar de novo...

Toma, já te dei o meu pé,

Amarra-me, com trinta nós:

Junto contigo, somos só nós dois;

Junto a mim, a pessoa que eu quero.

Nossos homens são como candeeiro

Com destino de iluminar:

Iluminar de noite, de dia,

Enquanto não apagarmos...

Ó corpo, ó corpo meu escravo,

Deita quietinho, silencioso:

Ó alma, deixa-me te aconselhar:

Voa livre, sem preocupações!

Essa corda de sacramento,

Ela veio, ela vai com o vento:

Mas, aquela corda santa de amor,

Só Deus sabe o seu valor!

Não obstante à mobilidade amorosa do sujeito lírico expressa na segunda estrofe ("Se eu sair do caminho/ Saberei entrar de novo..."), este incita a mulher escolhida a prendê-lo com "aquela corda santa de amor", certamente mais poderosa do que os "nós" referidos na terceira estrofe do poema:

Toma, já te dei o meu pé,

Amarra-me, com trinta nós:

Junto contigo, somos só nós dois;

Junto a mim, a pessoa que eu quero.

O amor correspondido, na obra de Eugénio, exige uma ação por parte da mulher ("Coloca-me a corda no pé com jeito,/ amarra-me"), à diferença da postura estática das musas camonianas e petrarquianas.

Em síntese, concordamos com Gabriel Mariano quando ressalta que "a principal linha de força da poesia de Eugénio Tavares é o Amor. Mas, que Amor? [...] Um veículo, uma escada de salvação, um meio através do qual se alcança um 
determinado objectivo" (1991, p. 126). Nas mornas de Eugénio, o Amor é um sentimento compartilhado que permite a comunhão entre a amada e o amador.

A lira de Eugénio Tavares "tem muitas cantigas que choram por dentro", de saudade ou de "cretcheu" (amor). O metapoema "Nha cantar" aponta os motivos para as mornas do velho e do novo - esperança e saudade - e define a sua própria poesia como "cantiga", "rima/ da minha saudade" (Nha cantiga é rima/ De nha sodade"), "fel" adoçado pela "graça de amor".

\section{Nha cantar}

Ó graça de amor

Endoçam es fel

De sofri nha dor

Sem mundo sabel!

Es cantar de meu

Stâ tiram alento:

Tem cantiga cheu

Que é chorâ pá dento...

Nobo tem esperança

Pâ ensinal cantâ:

Bejo tem sodade

Pâ fazel chorâ.

Nha cantiga é rima

De nha sodade:

Ai, ja'n tem bontade

De mordê nha Lima!

Rapariga noba

Que ca tem crecheu,

Se el morré, é na coba;

El ca ta bá ceu... (TMCC, p. 64).

\section{Meu cantar}

Ó graça de amor

Adoça esse fel

Que faz sofrer a minha dor

Sem que o mundo saiba!

Esse meu cantar

Me tira o alento:

Tem muitas cantigas

Que choram por dentro...

O novo tem esperança

Para ensiná-lo a cantar:

$\mathrm{O}$ velho tem saudades

Para fazê-lo chorar.

A minha cantiga é rima

Da minha saudade:

$\mathrm{Ai}$, já tenho vontade

De morder a minha Lima!

Menina nova

Que não tem bem-querer,

Se ela morrer, vai para a cova;

Ela não vai para o céu...

\section{5 - Morna (s) da partida}

Corpo, qu'ê nêgo, sa ta bai; Coraçom, qu'ê forro, sa ta fica ${ }^{48}$...

Esta passagem extraída de um "batuque" tradicional da ilha de Santiago, que Eugénio Tavares incorpora no seu mais famoso texto, refere a base escravocrata sobre a

\footnotetext{
${ }^{48}$ Tradução - "O corpo, que é escravo, vai; / O coração, que é livre, fica..."
} 
qual se formou a sociedade crioula e indicia importantes aspectos do imaginário do cabo-verdiano que, devido a variáveis geográficas e econômicas, é forçado a deixar a terra-mãe, desértica e pobre em recursos naturais, rumo à terra-longe.

A relação com o mar, numa pátria-arquipélago, constitui-se como um dilema cujos pólos são: a insularidade, gerada pela sensação de isolamento (sobretudo no período colonial, em que o mar traz a "caravela da opressão secular", segundo Ovídio Martins); por outro lado, o mar propicia a sobrevivência e ligação com a "terra-longe" e com o mundo. Ele tem o poder de isolar cada uma das ilhas, bem como o arquipélago como um todo. Entretanto, ele também tem o poder de servir como elo entre Cabo Verde e os demais países para onde seus filhos costumam emigrar. Fomenta os sonhos daqueles que aspiram partir em busca de uma vida mais tranqüila. $\mathrm{O}$ mar, portanto, é o caminho que leva o cabo-verdiano para outras paragens e que permite à sociedade de Cabo Verde sustentar um olhar direto ao mundo exterior.

Neste sentido, o mar funciona como um mediador, que não apenas provoca a separação, permitindo aos cabo-verdianos a vivência de outros mundos, mas atua como traço de união entre os que partem e aqueles que por razões várias permanecem na terra natal. O mar é, em muitas composições, personificado como um deus mítico, mensageiro, que dialoga diretamente com o poeta.

De acordo com o antropólogo cabo-verdiano João Lopes Filho (2007, p. 25):

O mar é responsável pela insularidade, mas também pela viagem, o que implica emigração e evasão, tendo em conta que, até há poucas décadas, era através dele que se podia sair da terra, voltar ou permanecer no estrangeiro (permanência e errância).

Vasco Martins acrescenta outro argumento a essa discussão:

O Mar, elemento mais constante e misterioso da ilha, e que dá a possibilidade de partir ou de pura evasão, é também uma fonte de inspiração para a poesia mornista. [...] O mar evoca quase sempre uma coisa desconhecida, misteriosa e dramática, e que produz evocações da morte (1988, p. 91).

E enfatiza:

O mar é nostalgia

O mar abismo profundo, indiferente à alma humana, é a sepultura da amada em Eugénio Tavares. 
Aliás, é de notar que a saudade é um facto sentimental imprescindível e que para o mornista tem que existir para o aprofundamento das emoções.

O mar, fazendo parte do imaginário cabo-verdiano, encontra na Morna uma possibilidade poética deveras sugestiva. O mar mensageiro é a temática mais interessante (1988, p. 92).

Desta forma, um núcleo rentável para o estudo das mornas eugenianas é o do terra-longismo, que abriga subtemáticas como: a partida, o exílio, a saudade, o mar.

A partida e toda a dor decorrente da experiência daqueles que emigram servirão de tema para diversas composições. A "Morna de despedida" torna-se, assim, um clássico da lavra de Eugénio Tavares:

\section{Morna de Despedida}

Hora de bai,

Hora de dor,

Ja'n q'ré

Pa el ca manchê!

De cada bez

Que 'n ta lembrâ,

Ma'n q'ré

Ficâ 'n morrê!

Hora de bai,

Hora de dor!

Amor,

Dixa'n chorâ!

Corpo catibo,

Bá bo que é escrabo!

Ó alma bibo,

Quem que al lebado?

Se bem é doce,

Bai é maguado;

Mas, se ca bado,

Ca ta birado!

Se no morrê

Na despedida,

Nhor Des na volta

Ta dano bida.

Dicham chorâ

Destino de home:

Es dor

Que ca tem nome:

Dor de crecheu,

Dor de sodade

De alguem

Que'n q'ré, que q'rem...

\section{Morna de Despedida}

Hora da partida,

Hora de dor,

É meu desejo

Que não amanheça! (não chegue a hora)

De cada vez

Que a lembro,

Prefiro

Ficar e morrer!

Hora de partida,

Hora de dor!

Amor,

Deixa-me chorar!

Corpo cativo,

Vai tu que és escravo!

Ó alma viva,

Quem te há de levar?

Se a chegada é doce,

A partida é amarga;

Mas se não se partir (mas quem não parte)

Não se regressa! (não regressa)

Se morrermos

Na despedida,

Deus no regresso

Dar-nos-á vida.

Deixa-me chorar

Destino de homem:

Oh dor

Que nem nome tem:

Dor de amor

Dor de saudade

De alguém

Que eu quero, que me quer... 
Dicham chorâ

Destino de home,

Oh Dor

Que ca tem nome!

Sofrí na vista

Se tem certeza,

Morrê na ausencia,

Na bo tristeza! (TMCC, pp. 41-42).
Deixa-me chorar

$\mathrm{O}$ destino do homem,

Oh Dor

Que não tem nome!

Sofrer junto de ti

Sem ter uma certeza,

Morrer na ausência,

Com a tua tristeza!

Segundo interpretação de Moacyr Rodrigues e Isabel Lobo, o tema da "partida para a América, em fuga ao flagelo da fome, retomado mais tarde por B. Lèza, motivouo a produzir os seus mais belos versos:

\begin{abstract}
Apesar da 'situação de partida' ser secular e ter sido normal durante o período escravocrata, Cabo Verde, após o desenvolvimento da 'nação cabo-verdiana', passou a reagir como uma família, um todo, e não como uma sociedade despersonalizada, constituída por gente arrumada 'como gado', daí o acto de partir ser pungente e não algo que se desejava e estava na psiqué cabo-verdiana. Sempre foi algo sofrido na carne com a separação, forçada não só pelo destino, como pelos senhores da terra (RODRIGUES \& LOBO, 1996, p. 70).
\end{abstract}

Não esqueçamos de que a época em que Eugénio Tavares viveu é a da emigração para a América, de fomes seguidas e luta política de monárquicos contra republicanos, de perseguições constantes de idéias defendidas. Partir, portanto, não pressupõe negar a terra, esquecê-la, porque supõe sempre um regresso ou o desejo dele.

"Morna de Despedida" pode ser considerada uma das mais completas criações de Eugénio Tavares, uma vez que nela podemos encontrar os temas mais relevantes das mornas cabo-verdianas. O sujeito poético se agarra à dor daqueles que, "escravos" da situação pouco animadora vivida pelas ilhas cabo-verdianas na época, necessitam partir para fugir aos problemas, numa eterna busca por melhores condições de vida para si próprios e para os entes queridos que ficam. No poema, o leitor pode perceber toda a tristeza do eu lírico pelo fato de ter de deixar a terra natal.

$\mathrm{Na}$ primeira estrofe, registramos esse momento como sendo o instante da dor, como podemos observar nos dois primeiros versos: "Hora da partida,/ hora da dor". Para prolongar os momentos que lhe restam, ao poeta cabe somente desejar que não amanheça, não chegue essa hora tão indesejada. Todavia, como consolo, o sujeito lírico observa que só aquele que partiu (versos 18 e 19) pode voltar (momento de felicidade): "Mas se não se partir/ Não se regressa!" 
É no poema que o eu lírico se encontra identitariamente e pode falar da terralonge, da distância, da saudade, numa nostalgia que um dia certamente terminará, ao retornar à Terra e ao Amor.

Observa-se que Amor vem grafado em maiúscula, podendo representar 'tudo' o que se ama. Com efeito, podemos deduzir que aqui se unem todos os tipos de 'Amor', que marcavam fundo o coração do sujeito poemático, com relevo para o Amor à TerraMãe (“Se morrermos/ Na despedida,/ Deus no regresso/ Dar-nos-á vida”).

Sem sombra de dúvida, foi Eugénio Tavares quem melhor expressou e cantou, em suas composições, o registro da dor, da saudade, da partida e também do regresso daqueles que por um motivo ou outro tiveram que deixar o seu país. E ainda que o mundo literatura venha a ser aquele das 'coisas inventadas', não podemos fazer vista grossa aos conceitos do 'real', existentes nas cantigas produzidas pelo poeta bravense.

Este artista popular cabo-verdiano com seu espírito observador e repleto de determinação soube como ninguém mais buscar nas tradições sócio-culturais de seu pequeno país e da época por ele vivida, os motivos para a composição de seus versos e textos. E, ainda, teve a inspiração para recriá-los e recheá-los de poesia, mantendo um estilo próprio e encontrando novas maneiras de cantar a morna, diferentemente das mornas antigas da Boavista, ilha tida como berço desta modalidade musical.

É com propriedade que Vasco Martins afirma que:

A saudade e a partida também fazem parte do universo literário da Morna. Depois da temática do amor, é a inspiração mais freqüente. Cabo Verde, país de emigração maciça, país de ilhas e de Oceano, possui na sua alma a mitologia da partida que tem sempre um regresso ou pelo menos a idéia do regresso. A saudade é um sentimento que acompanha a partida, uma saudade romanceada, por vezes profunda e pondo em causa a Terra longe, onde se vai buscar um melhor modo de vida ou, simplesmente, a necessidade de ver o mundo, sair das ilhas para um encontro com outras culturas, outros modos de vida, outras mentalidades. No confronto dessas culturas, a Morna resta uma temática sentida profundamente, é um elo de união e de recordações, é a canção onde se transmite a saudade da ilha, de um antigo amor, da mãe, figura que liga o homem cabo-verdiano à terra, através de lembranças de infância, tentativa de retorno à simplicidade e ao aconchego materno. [...] A mãe é a continuação para o mornista e o cabo-verdiano da simplicidade e do amor e dos ambientes psicológicos da infância e adolescência que acompanham a alma cabo-verdiana toda a vida (1988, pp. 89-90). 
"Hora de Bai", de Eugénio Tavares traduz o drama do homem cabo-verdiano na tomada de decisão entre o partir e o ficar. Este mote da cultura de Cabo Verde, grandemente explorado pelos escritores do movimento literário claridoso, acabou por tornar-se um leitmotiv da literatura deste pequeno país da costa atlântica africana.

Anteriormente ao surgimento da Revista Claridade, Eugénio já lidava com certa mestria com o conflito de sentimentos descrito: a dor de ter de partir e a vontade de não abandonar o torrão natal, a necessidade de o deixar para num futuro não muito distante regressar, o sonho de poder vivenciar a experiência da emigração, igualando-se a tantos conterrâneos que já o fizeram. Se fato de deixar a sua ilha natal é algo extremamente sentido, a sua antípoda recompensa é o regresso deste a Cabo Verde.

Emigrar proporciona a quem o faz distinção e prestígio, que só consegue desfrutar em plenitude quando do regresso. Conforme elucida Juliana Braz Dias,

mornas play a fundamental role by helping construct the concepto of return as a value. As noted above, it encourages Cape Verdeans to leave, turning the painful departure into precisely the other side of the coin for those who want to harvest the fruits of the much valued return. Departure and return, death and life: one does not exist without the other ${ }^{49}(2008$, p. 181).

Inserida ainda no núcleo do terra-longismo, a morna "Despedida" associa emigração e mar, reiterando a díade partir-voltar e carregando a partida de mágoa, tristeza, morte e luto. Regressar permanece no "doce" e "claro" campo da esperança.

\section{Despedida}

(Marinheiros que partem)

Es mágua de nha partida El sâ tâ matam nha bida! Se'n bai, ramede que tem, É'n bai, 'n tornâ bem.

Mas es tristeza de'n bai, De'n bai pa'n largâ nha Mai, El ca triste comâ dor De'n bai pa'n largâ nha Amor.

\section{Despedida}

(Marinheiros que partem)

Essa mágoa da minha partida

Está matando a minha vida

Se eu for, remédio não tem,

Eu fui e voltei.

Mas essa tristeza de partir De partir e deixar minha mãe, Isso não é triste como a dor De partir e deixar meu Amor.

\footnotetext{
49 “[...] a morna tem aqui um papel fundamental na construção do regresso como um valor. Mais uma vez, ela ajuda a incentivar os cabo-verdianos a partir, fazendo da dolorosa partida apenas o outro lado da moeda para quem quer colher os frutos do valorizado retorno. Partida e regresso, morte e vida: não há como pensar um sem o outro".
} 
No cantâ co água na ôjo;

No bajâ co alma de nôjo:

Hora triste de partida

É hora de perdê bida.

Quem que ficâ, ca ta bai:

Quem que ca bai, ca ta bem:

Força que pincha'n pa'n bai,

É bo, esperança de bem!

Ó bai, ó bai, ja bo triste!

Ouro de mar, ja bo caro!

Ó bem, ó bem, ja bo doce!

Dia de bem, ja bo claro! (TMCC, p. 47).
Cantamos com água nos olhos;

Dançamos com a alma de luto:

Hora triste de partida

É hora de perder a vida.

Quem fica, não parte:

Quem não parte, não volta:

A força que me empurrou para ir

És tu, esperança de voltar!

Ó partida, ó partida, tu és triste!

Ouro do mar, tu és caro!

Ó volta, ó volta, tu és doce!

Dia do retorno, tu és claro!

Em correlação ao mote da partida, o poeta desenvolve a temática da saudade, com base na imagem das andorinhas que voltam. O mar ("aberto", "caminho"), o vento e as asas possibilitariam o regresso à terra, ninho amado.

\section{Andorinhas de bolta}

Andorinhas de mar largo, Que bento de lialdade Botanhôs nes passo amargo, Na es nos terra de Sodade?

Pamô danhôs na bontade De torna bem nes caminho? $\mathrm{Ai}$, de bem mata sodade De nos terra, de nos ninho?

A mi, ja'n tem nha cudado, Ja'n tem nha cabelo branco: Mi é bejo, mi é manco, Mi é um candía pagado...

Quem que é nobo, tem esperança, Tem sê graça, tem sê fé... Mocidade é mar na bonança; É luz que Nos Senhor cendê...

Andorinhas de mar alto, Nhos bem de bolta pa casa? Triste é mi que ja esta falto De penas bibo na asa... (TMCC, p. 51).

\section{Andorinhas de volta}

Andorinhas do mar aberto, Que vento de lealdade Coloca-nos nesse passo amargo, Nessa nossa terra de saudades?

Por que nos deu vontade De voltar nesse caminho? $\mathrm{Ai}$, de voltar para matar as saudades! Da nossa terra, do nosso ninho?

Eu tenho uma preocupação, Já estou com os cabelos brancos: Sou velho e aleijado, Sou um candeeiro apagado...

Quem é novo, tem esperanças, Tem sua graça, tem sua fé... Mocidade é o mar em bonança; É luz que o Nosso Senhor acendeu...

Andorinhas de mar aberto,

Regressam para casa?

Triste sou eu, com falta

De penas vivas nas asas...

A terceira estrofe evoca a velhice, encarada como impossibilidade de volta do emigrado à terra-mãe: a "falta de penas vivas nas asas" e o "candeeiro apagado" são as imagens utilizadas pelo poeta para negativizar a esperança de regresso. Nesta "morna- 
estado-de-alma", o sentimento que torna mais aguda a saudade é o de nostalgia (do grego nostós, regresso+ álgos, dor, abatimento profundo) de quem sabe que nunca mais voltará à sua pátria.

A saudade do ser amado também alimenta a esperança de voltar, na mornística de Eugénio Tavares. O refrão do poema enfatiza o seu motivo:

\section{Sodade de quem que'n q're!}

De todo mágua des mundo, Quel que é mas doce, mas fundo, É quel que é dor a má fé: É quel que tenem em pé: É quel que ta doé más fundo: Sodade de quem que'n q'ré!

Es corage de largâ Nos luz, nos amor, nos fé, É esperança de voltâ... Cose és? Quem que dam el? Es amargo todo? Es mel? Sodade de quem que'n q'ré! (TMCC, p. 46).

\section{Saudade de quem eu amo!}

De toda a mágoa desse mundo, Aquela que é mais doce, mais funda, É aquela que é dor a má fé:

É aquela que nos mantém de pé: É aquela que dói mais fundo:

Saudade da pessoa que eu quero!

Essa coragem de abrir mão

De nossa luz, nosso amor, nossa fé, É a esperança de voltar...

Que coisa é essa? Quem me deu isso?

Esse amargo todo? Esse mel?

Saudade da pessoa que eu quero!

A dor da ausência ou saudade (do latim solitate, lembrança de coisas ou pessoas distantes ou extintas acompanhada do desejo de as tornar a ver ou possuir) do ente querido que ficou na terra-mãe está bem caracterizada neste poema, que supõe partida (terra-longismo, na denominação de Manuel Ferreira) e regresso.

António Germano Lima refere a nostalgia e a saudade como "dois dos sentimentos que mais ligam a alma humana à sua terra-mãe e, por isso, estão intimamente ligados à separação do homem do local onde foi enterrado o seu umbigo" (2001, p. 259).

A morna lírica, do estado-de-alma, é a vertente da modalidade bravense para a qual mais contribuiu Nhô Eugénio, ladeado, mais tarde por B. Léza ${ }^{50}$.

\section{6 - Mornas de costumes ou de filosofia/religiosidade popular}

Quem que tem medo

Ta morrê cedo ${ }^{51}$.

Eugénio Tavares

\footnotetext{
${ }^{50}$ Conferir a morna "Eclipse".

${ }^{51}$ Quem tem medo/morre cedo.
} 
Para completar nossa leitura da poética mornística de Eugénio Tavares é necessário examinar modalidades que provavelmente têm sua origem na estrutura da finason crioula, isto é, nos conselhos ou comentários tecidos musicalmente pelas cantadeiras de batuque, plenos de provérbios, sentenças, análises de costumes populares. Afirma Moacyr Rodrigues, como já referido, que as mornas, inicialmente, eram interpretadas por mulheres do povo, remontando as primeiras cantigas provavelmente aos finason (herança africana) ou cantos improvisados produzidos pelas finadeiras no batuque e possivelmente levados da ilha de Santiago para a ilha da Boavista (RODRIGUES, 1986).

Assim, a morna é uma forma que tematiza as coisas simples do cotidiano, o correr da própria vida e os princípios da sabedoria popular que a regem. Ela nasceu no terreiro e daí partiu para os salões, havendo na sua evolução um processo de trocas contínuas (terreiro/salão, aspectos populares e aspectos aristocratizantes) que resultará na modalidade que hoje conhecemos (GONÇALVES, 2006, p. 87).

A morna "Lua noba", por exemplo, superpõe as imagens da lua e de Nossa Senhora na bênção àquele que sofre e na Luz, de natureza diversa, que ambas irradiam, expressando a religiosidade sincrética cabo-verdiana, fundada na mestiçagem.

\section{Lua noba}

Ó nha Madrinha Lua, Nha Madrinha de Ceu, Nha botam quel bençom; Nha Madrinha de meu!

Ó nha Madrinha branca, Ca nha esquicê de mi! Nhá dixam ta chorâ, Ai, pa nha acham ta arri!

Ó nha Madrinha Santa, Nhá pegam na nha mom, Nha lumiam na nha passo, Ai, nha botam bençom!

Nha espiam la de Ceu, Nha judam co nha cruz! Nha Madrinha, nha Mai, Nha Madrinha, nha Luz! (TMCC, p. 54).

\section{Lua nova}

Ó Lua, minha Madrinha, Minha Madrinha do Céu, Abençoa-me; Minha Madrinha!

Ó minha Madrinha branca, Não esqueças de mim! Tu me deixaste chorando $\mathrm{Ai}$, para me encontrares sorrindo!

Ó minha Madrinha Santa,

Segura a minha mão, Ilumina os meus passos, Ai, me abençoa!

Olha-me lá do Céu, Ajuda-me com a minha cruz! Minha Madrinha, minha Mãe, Minha Madrinha, minha Luz!

Para Gabriel Mariano, o sincretismo religioso deriva do fato de a cultura caboverdiana ter se formado com a apropriação pelo funco das manifestações do sobrado, ou 
seja, a africanização da cultura européia realizou-se de forma vertical, com a primazia do mulato na produção de formas culturais. Com o contínuo aumento da mestiçagem e a ascensão econômica e social do mulato, expressões de cultura mestiça, provavelmente formadas no funco, alastraram-se pelo arquipélago. Este é o caso da morna, patrimônio do folclore poético e musical, como foi o caso da língua crioula, da culinária, das adivinhas, dos provérbios, dos festejos populares, das superstições, dos esquemas comportamentais (MARIANO, 1991, p. 54).

Na morna "Que alma ja bem papiâ..." sobressai o veio católico da religiosidade crioula, mas com pitadas dos ditos populares utilizados nos finason: "Nha boca é porta fechado,/ Co chabe lâ pâ alboredo..."

\section{Que alma ja bem papiâ...}

Quel alma ja bem papiâ, Ja el bem limpâ sê cabeça. Mas, el bem co todo pressa, Pa mentira ca pegâ.

Mi jam flal mâ nos é tres, Nos é tres na nos segredo: Dos pecador, co Nhor Des, Ai, co Nhor Des nos é tres... Se Deus tomano de um bes, Mi jam flal pâ el ca tem medo, Pamode, na es nos pecado, Nha boca é porta fechado, Co chabe lâ pâ alboredo...

Se é pâ morré ferido, É mejor vivé enganado: Perde quel que era perdido, Ca parcem grande pecado... Só bó, Berdade de Dor, Só bó bo ca ta ba fundo! Só Deus que conchê sê mundo, El só el sabé sê valor... (TMCC, p. 44).

\section{Aquela alma já veio falar...}

Aquela alma já veio falar, Ela veio limpar a sua cabeça Mas, ela veio bem apressada, Para não ser pega em mentira.

Já lhe disse que somos três, Somos três com o nosso segredo: Dois pecadores e o Nosso Senhor, Ai, com o Nosso Senhor somos três... Se Deus nos levar de uma vez, Eu já lhe disse para não temer Porque, no nosso pecado, Minha boca é porta fechada, E a chave está jogada no meio do arvoredo...

Se for para morrermos feridos, É melhor vivermos enganados: Perder aquilo que era perdido, Não me parece grande pecado... Só tu, Verdade de Dor, Sozinho tu não vais longe!

Só Deus conhece o teu mundo, Só ele sabe o teu valor...

Em “Cosas dês mundo”, a estrutura mornística é construída com base na adição de provérbios que expressam a sabedoria do cotidiano num processo paralelístico de questionamento (confira-se a repetição da forma interrogativa) filosófico-popular ou de filosofia de reflexões sapienciais ao qual se adiciona uma apostrófica (“ó Deus"; “Devagarzinho, Deus") conversa com o Criador: 


\section{Cusas des mundo...}

Se quem que arri tem poço sentimento, Quem que chorâ é mujer...

Quem papiâ tené juizo na bento, Quem que calâ é manhento...

Quem que morâ na campo ca'q're trato Trato co gente dreto...

Quem que pô mom na preto

Pa el fla Nhor Des matal, é bentecato...

Cusas des mundo! No estâ vivê nel

Amá, té quando, ó Deus, no al entendel?

Se no sotâ mujer, no ca tem crerto, Ja no perdê nos nome...

Se nos mujer sotano, é mas que certo No bem morrê de fome...

$\mathrm{Na}$ fim de jogo, no al pode co peso

$\mathrm{Na}$ nos triste cabeça?

No al pode co despreso?

Debagarinho, Deus, na ca tem pressa...

Cusas des mundo! No estâ vivê nel Amá, té quando no al entendel? (TMCC, p. 45).

\section{Coisas desse mundo...}

Se quem ri tem pouco sentimento,

Quem chora é mulher...

Quem fala tem cabeça no ar,

Quem não se cala é oportunista...

Quem mora no campo não quer convívio

Convívio com gente correta...

Quem coloca a mão no peito

Para pedir a Senhor Deus que o mate, é abençoado

São coisas desse mundo! E nós vivemos nele

Mas, até quando ó Deus, havemos de entendê-lo?

Se batermos em mulheres, não teremos crédito,

Perderemos logo o nosso nome...

Se nossas mulheres nos baterem, é mais que correto

Vamos morrer de fome...

No fim do jogo, vamos estar com muito peso

Na nossa triste cabeça?

Seremos vistos com desprezo?

Devagarzinho, Deus, não temos pressa...

São coisas desse mundo! E nós vivemos nele Mas, até quando havemos de entendê-lo?

Nesta morna percebe-se nitidamente o princípio brincalhão e satírico originário de mornas da ilha da Boavista (algumas delas reescritas por Eugénio Tavares), "mornas-comentário" (LIMA, 2001, p. 263) ${ }^{52}$ que exploravam o caráter lúdico provavelmente colhido nos finason da ilha de Santiago, em que as finadeiras criticavam ou ironizavam comportamentos sociais com funções normativa e morigeradora.

No texto que apresentaremos a seguir, unido aos anteriores pelo fio do apelo à religiosidade católica, a mãe (ou a ama de leite) embala o bebê para dormir e, ao mesmo tempo, trata da grande questão do ser humano que é apartado de seu ninho-"colo materno" e jogado no mundo aberto da vida e, posteriormente, no sono da morte (como o homenageado comandante Adelino de Oliveira). Aqui, a função da cantiga de ninar, em consonância com os costumes cabo-verdianos, é expulsar o mal do sono e da vida do menino: Não, ó menino não,/ Sombra ruim sai daqui!/ Não, ó menino não,/ Deixa meu filho dormir... 


\section{Ná, ó menino ná...}

À alma do malogrado comandante Adelino de Oliveira

Ó rosto doce de ojo maguado,

Es bo cudado

Botal pa traz!

Nhor Des ta dano um bida de paz,

Ó nha Pecado

De ojo maguado!

Ná, ó menino ná,

Sombra rum fugi de li!

Ná, ó menino ná,

Dixa nha fijo dormi...

Sono de bida, sonho de amor,

Ou graça, ou dor,

Es é nós sorte...

Se Deus, más logo, mandano morte,

Quem que tem medo

Ta morrê cedo.

Toma nha ombro, encosta cabeça,

Ja'n dabo peto,

Amá ragaz!

Ó esprito doce, ca bo tem pressa:

Deta co geto,

Dormi na paz... (TMCC, p. 35).
Não, ó menino não...

À alma do malogrado comandante Adelino de Oliveira

Ó rosto doce de olho magoado

Essa tua preocupação

Joga-a para trás!

Senhor Deus nos dará uma vida de paz,

Ó meu pecado

De olho magoado!

Não, ó menino não,

Sombra ruim sai daqui!

Ná, ó menino ná,

Deixa meu filho dormir...

Sono da vida, sono do amor,

Ou graça, ou dor,

Essa é a nossa sorte...

Se logo mais, Deus me mandar a morte,

Quem tem medo

Morre cedo

Toma o meu ombro, encosta a cabeça,

Já te dei de mamar,

Ama o colo!

Ó espírito doce, não tenhas pressa:

Deita bem,

Dorme em paz...

A respeito das cantigas de ninar, esclarece Nuno Miranda que "a literatura oral compete enquadrar as canções de embalo que ficaram pairando das vozes não esquecidas da escrava ama" ${ }^{\text {, }}$, já que as relações afetivas entre as amas e os filhos dos patrões terão sido "um dos fatores determinantes na criação e modelação da morna" (LIMA, 2001, p. 261). Essas amas, muitas delas cantadeiras (kantaderas), foram compositoras das mornas dos tempos remotos.

Em síntese, Eugénio Tavares, em sua obra poética, descortina uma representação da cultura cabo-verdiana e imagens de Cabo Verde de riqueza tal que fornecem até os dias de hoje material para aqueles que querem refletir sobre a formação e a evolução das formas literárias e musicais em língua portuguesa e, especialmente, crioula. Os temas que aborda, o percurso da morna que traça, as partituras que compõe (como não iniciado, mas pleno de conhecimento prático da música) ajudam a compor o retrato de uma época e de um povo.

\footnotetext{
${ }^{53}$ Apud LIMA, 2001, pp. 261-262.
} 
Como grande defensor da utilização da língua de berço, Eugénio Tavares foi um dos primeiros escritores a registrar para a posteridade as tradições cabo-verdianas, transferindo para o papel o patrimônio imaterial de sua gente, que não poderiam ser melhor expresso senão na língua "sabe" de todos os cabo-verdianos: o crioulo.

Segundo a lenda, quando Tatai (apelido carinhoso dado pelo povo a Eugénio Tavares) morreu, a ilha Brava chorou e uma jovem da fonte de Vinagre exclamou: "Si Nhô Eugénio dja morrê, Dja Brava dja caba!" 


\title{
REFLEXÕES CONCLUSIVAS
}

O exemplo da vida de Eugénio Tavares impressiona, sobretudo,pela coerência da sua fidelidade a Cabo Verde, afirmando-se como um dos precursores da caboverdianidade.

Manuela Ernestina Monteiro

Em recente entrevista realizada em Cabo Verde, cidade da Praia, com o investigador e Pró-Reitor de Pesquisa da Universidade de Santiago, Professor Doutor Manuel Brito-Semedo (dezembro 2009) ${ }^{54}$, sobre a obra e a personalidade de Eugénio Tavares, indagávamos a opinião de Semedo a respeito da inexistência de uma leitura mais atenta da obra tavariana, em especial da sua poesia em língua portuguesa, assim como sobre alguns pré-conceitos que postulam ser esta produção menos significativa do que a poética em língua crioula. Brito-Semedo assim se pronuncia:

\begin{abstract}
Quando se fala da poesia de Eugénio Tavares, fala-se, sobretudo, da poesia crioula. Eugénio Tavares, para fazer tudo o que fez, em termos de plasticidade da língua cabo-verdiana, teria que conhecer muitíssimo bem a língua portuguesa. Ele traduz o clássico de Camões a endecha "aquele bonitu escraba que tem n'catibu", dedica o livro de poesia Mornas - cantigas crioulas a João de Deus e faz versões de poemas para o crioulo. Portanto, ele teria de conhecer muitíssimo bem o idioma luso. Mas isto é para dizer que Eugénio Tavares, de fato, só passa a ser conhecido e estudado a partir do excelente trabalho que Félix Monteiro fez de recolha em três livros da sua publicação dispersa. O que as pessoas conheciam de Eugénio Tavares até relativamente pouco tempo era somente produto da oralidade, da memória coletiva. Somente a partir de 2000, propriamente, ele é reconhecido politicamente, os livros são publicados [...]. O que era conhecido de Eugénio Tavares era, em termos da poesia, a morna, e esta faceta bem popular (o popular, somente o popular). Portanto, só o popular, o erudito não era conhecido. E somente agora as pessoas passam a conhecer os textos relativos a essa vertente jornalística, polemista etc (2009).
\end{abstract}

A marca de nossa pesquisa e desta tese reside, portanto, na leitura vertical da produção eugeniana pouco conhecida, tanto do público quanto da academia. Como complementa Brito-Semedo, nesse século XXI, a partir da publicação das recolhas de Félix Monteiro, "há interesse [...], Eugénio é estudado ao nível das cátedras, das universidades".

\footnotetext{
${ }^{54}$ Por Genivaldo Rodrigues Sobrinho e Grupo de Estudos Cabo-verdianos de Literatura e Cultura CNPq, USP, líder Simone Caputo Gomes, em processo de trasncrição para futura publicação.
} 
O desconhecimento, até então, da obra literária de Eugénio Tavares, justifica certos juízos de valor precipitadamente que lhe têm sido atribuídos. Esclarece Semedo:

Penso que é preciso relativizar; às vezes, fazem-se certas afirmações, porque não se conhece tudo o que ele produziu. A poesia em língua portuguesa não era muito conhecida e fazem uma afirmação dessas, quando não se conhece completamente essa outra vertente; cosidera-se que Eugénio Tavares é um excelente poeta, sobretudo, em crioulo, porque conhecemos mais, em termos da quantidade, esta produção. Mas de qualquer forma, é um excelente poeta em língua portuguesa também. Essa é a minha opinião. Portanto, é preciso estudar essa produção de Eugénio Tavares em língua portuguesa (Ibidem).

Procuramos, em nossa pesquisa, demonstrar como, desde a prosa de intervenção social, exposta na produção em periódicos e na produção epistolar até a poesia, veiculada nas línguas portuguesa e cabo-verdiana, o amor a Cabo Verde, em todas as suas formas, é a tônica da obra de Eugénio Tavares.

Se é certo que Eugénio Tavares elegeu o amor como tema principal da sua produção poética, o amor é, igualmente, o sentimento que enforma a parcela mais significativa da presente compilação [da obra em prosa]. $\mathrm{O}$ amor intenso e devotado à terra-mãe, muito particularmente à ilha de nascimento, e ao cabo-verdiano humilde, que procurou defender com a única arma de que dispunha: a sua pena de homem letrado, culto e dotado de grande sensibilidade (MONTEIRO, 1999, p. 5).

Mestre Eugénio teve como escopo defender a identidade e a língua caboverdianas, para a formação e sedimentação das quais contribuiu, dignificando tanto a "personalidade" do homem crioulo quanto conferindo beleza e estatuto literário à sua máxima expressão, a língua.

Em consonância com a proposta de Stuart Hall (1997) para conceituar identidade, a figura simbólica de Eugénio Tavares, a força de sua combatividade jornalística e, sobretudo, de sua poesia, especialmente a que se comunicava com o homem comum pela via da morna, ajudou a forjar uma "identidade cultural" ancorada em aspectos coletivos relacionados à pertença crioula - emocional, linguística, religiosa, regional e/ou nacional. Tavares começa a delinear a noção de nação como sistema de representação cultural, produzindo na totalidade de sua obra sentidos (estórias, memórias, sentimentos, imagens) com os quais os cabo-verdianos de todas as classes se identificavam, à sua época, e se identificam ainda hoje, guardadas as proporções entre um Cabo Verde colônia e a nação atual, de desenvolvimento médio. 
Embora defendendo os seus ideais político-sociais e a melhoria da qualidade de vida do povo cabo-verdiano prioritariamente em língua portuguesa, para melhor atingir os objetos de suas denúncias (os governantes), assim como alcançando altos níveis de lirismo amoroso e de crítica social na poesia em língua lusa (das quais nunca esqueceu os grandes mestres como Camões, João de Deus e Antero), Eugénio postulava que "o dialeto cabo-verdiano" podia ser grafado, além de falado (TPJ, pp. 218-219).

Desta opção por retratar Cabo Verde e sua cultura também na língua de seu povo, surgem as mais belas mornas e novas modalidades da morna concebidas pelo espírito amorável da ilha das flores, a Brava. Eugénio acrescentou à morna originária da Boavista, de teor mais satírico, o tempero do amor, tanto de raiz romântica lusa (sentimento compartilhado pelos poemas de idealismo amoroso em língua portuguesa) quanto de teor realista crioulo, tematizando a possibilidade de reciprocidade por parte da "cretcheu", trazendo os dilemas e contrastes amorosos para o terreno da realidade popular. O amor correspondido, na obra de Eugénio, que supõe ação por parte da amada (“amarra-me"), já é uma possibilidade de retirar a mulher cabo-verdiana de um estado de passividade que seria evocado pela postura estática das musas camonianas e petrarquianas que inspiraram a poesia eugeniana de língua portuguesa. Nas mornas, a comunhão entre a amada e o amador é um traço de modernidade.

O desencanto, o desconcerto do mundo também foram assuntos abordados, tanto na prosa quanto na poesia, com destaque para a leitura do desconcerto pelo viés da obra camoniana, evidenciada na poesia de língua portuguesa. A presença de Camões é tão forte na arte eugeniana que ele chega a verter poemas do mestre luso para o crioulo.

No que toca aos textos publicados em jornais e à epistolografia, o desconcerto do mundo coincidirá, em grande parte, com a crítica ao "desgoverno" colonialista em Cabo Verde. A incapacidade e o desinteresse dos administradores pelos problemas de infraestrutura em Cabo Verde, à época da escrita de sua obra, as questões relativas à emigração espontânea ou forçada, o preconceito dos europeus brancos contra os caboverdianos, a possibilidade de venda das colônias, entre outros temas sociais, levam Nhô Eugénio a atacar com veemência, em prosa e poesia em língua portuguesa, especialmente, os mandatários coloniais e a propor soluções eficientes para problemas crônicos como as crises de seca e fome.

A emigração espontânea, mormente para os Estados Unidos da América, já era apresentada pelo jornalista Eugénio como solução para o desenvolvimento de Cabo 
Verde (consideremos que, hoje, a diáspora é a décima primeira ilha, rendendo divisas necessárias à nação), tendo a temática destaque também na sua epistolografia e na sua poesia. No artigo "Questões Económicas", publicado em A Voz de Cabo Verde, o intelectual declara que o cabo-verdiano, nas terras para onde vai trabalhar "vai procurar seiva para aprofundar e fortalecer as raízes que deixou nas suas ilhas". Na carta "Noli me tangere", Eugénio define a emigração como "factor de progresso" que deve ser fomentado e defendido (TVTCP, p. 232).

A emigração para S. Tomé, porém, é rejeitada por Eugénio Tavares, tanto na produção em prosa quanto nas mornas, pelo argumento contrário: não favorece o desenvolvimento e dizima famílias, com a doença ou a morte dos trabalhadores nas roças, impossibilitando o seu regresso à terra de origem.

No combate, por meio da palavra, em prol da qualidade de vida para a população cabo-verdiana, Eugénio advogou o direito à instrução de qualidade, para que os cidadãos crioulos pudessem conscientizar-se e exercer atuação política. O jornalista Eugénio Tavares não se conformava, também, com a pouca iniciativa dos povos das colônias portuguesas na África, por não lutarem pela autonomia face a um regime que reputava "de sujeição” (TPJ, p. 174). “A África para os africanos” (TPJ, p. 70, artigo "Autonomia"), na virada do século XIX para o século XX, era uma proposta bastante ousada, lançada a partir do exílio.

Quanto à discussão sobre o "caráter ou personalidade" do homem caboverdiano, Eugénio Tavares, no texto "Os indígenas de Cabo Verde são desleixados, indolentes e bêbados?", recusa as opiniões preconceituosas dos "brancos" detentores de cargos administrativos e acaba por generalizar o tópico da bebida: "Porque é que haveis de atribuir ao preto, e só ao preto, um vício que está generalizado em todo o mundo e em todas as camadas sociais?" (TPJ, p. 106). O argumento encontra eco também no discurso poético em língua portuguesa, como o demonstramos no segundo capítulo, comprovando que as preocupações eugenianas com os direitos, a moral, a justiça em Cabo Verde se desdobravam em todo o mosaico de sua produção literária.

Além da defesa dos fracos, dos marginalizados e da bandeira da caboverdianidade, Eugénio Tavares, desde muito cedo, pugnou pelos valores republicanos e democráticos, pela liberdade de expressão e direitos da imprensa. Por esses motivos, por seu espírito polêmico, suas convicções políticas e pelo alcance de sua escrita, foi temido e atacado por ferozes adversários, sendo, em conseqüência, alvo de perseguições. 
Por outro lado, o homem preocupado com questões sociais, políticas e filosóficas encontra no amor o seu grande tema, que o consagra na memória caboverdiana das mornas (complexo de poesia, música, dança) em língua crioula, mas não deixa de pontificar também na poesia de língua portuguesa. Nesta, o poeta apresenta, com ecos camonianos, as constantes contradições amorosas, retomando uma linha temática universal da angústia de amar, produtora de textos antológicos de grandes escritores como Petrarca, Góngora, Luís de Camões, aos quais se irmana.

A postura romântica manifesta-se tanto na poética em língua portuguesa quanto nas mornas crioulas, tendendo para o ultrarromantismo tardio na primeira, como buscamos demonstrar no segundo capítulo. No que toca à morna, como enfatiza António Germano Lima, nela também repercutirão tonalidades e melodias do fado, assim como da lírica camoniana (2001, p. 244), mas Eugénio dá aos poemas em língua cabo-verdiana temperos tipicamente crioulos que, segundo Manuela Ernestina Monteiro, desenham a "epopéia sentimental” da nação (1999, p. 5).

Para o poeta Luís Romano, "quando as mornas de Nhô Eugénio são anunciadas, há como que uma homenagem sentida àquele que soube ler no coração das pessoas" (1986, p. 7) e, mais que tudo, no coração cabo-verdiano.

Em síntese, o lirismo amoroso constitui a linha forte da poética eugeniana, como ressalta Gabriel Mariano (1991, p. 126) e, reiteradamente no bloco de língua portuguesa, pode revestir-se de uma carga de idealismo, de religiosidade cristã ou mesmo de redenção sacralizante dos males do mundo. O "Mal de amor", cantado nas línguas portuguesa e cabo-verdiana, reveste-se de semelhante inspiração romântica, em que o cenário natural intensifica o estado psicológico do eu, que, num ambiente de soturnidade, vive a sua solidão, o seu desencanto pelo abandono.

Quanto à forma dos poemas, as mornas são expressas em quadras populares, com alguma frequência, mas podem apresentar variações nesse sentido; os poemas em língua portuguesa também variam, embora o soneto seja a estrutura predominante, sobretudo quando o assunto do texto é filosófico ou amoroso.

Uma linha de abordagem que pode acarretar confluências entre as poéticas de língua portuguesa e crioula - a par dos núcleos temáticos semelhantes, que recortamos em ambas - centraliza-se nas funções que Eugénio Tavares empresta às mornas, assim como aos poemas em língua lusa. Já afirmamos, com apoio de Luís Peixeira, que a morna "conta histórias, descreve paisagens e estados de alma, satiriza condutas" (2003, 
pp. 171). Esta asserção vale também para poemas expressos no idioma luso, com um fio narrativo, como "Perdida", "O pescador", "Noite de S. João", "Ressurreição”, entre outros; que descrevem paisagens e estados de alma, como "Chico e Berta", "Triste regresso", "Os tristes", "O exilado"; e satirizam condutas, como os sonetos do que podemos denominar "ciclo social da iluminação pública e do saneamento".

Para Isabel Lobo, na poesia de Eugénio, dominam as seguintes linhas de força:

o descritivo, como louvor da terra; o descritivo como expressão do 'eu' face à Natureza abstractizada; o amor e demais sentimentos como expressão do 'eu' face ao sublime; a crítica e a sátira, ligadas ao descritivo ou ao factual, como expressão do 'eu' face ao real” (1996, p. 6).

Embora a morna lírica, do estado-de-alma (correlata, nos poemas de língua portuguesa, aos textos de idealismo amoroso), seja a vertente da modalidade bravense (e, mais tarde, nacional) para a qual mais contribuiu Eugénio Tavares, outro núcleo rentável para o estudo das mornas eugenianas e dos poemas em língua portuguesa é o do terra-longismo, que engloba subtemáticas como: a partida, o exílio, a saudade, o mar. A Hora di bai eugeniana poderia constituir uma divisa da bandeira cabo-verdiana: ao chegar ao aeroporto da Praia e adentrar o território crioulo das ilhas, acolhem-nos, num monumento, os versos de Eugénio Tavares: "Se kabadu, ka ta biradu" ("Quem não parte, não regressa”), endereçados, sobretudo, aos cabo-verdianos que se afastavam, por algum motivo, da terra-mãe.

A emigração, encarada como consequência dos dramas da seca e da fome pelos claridosos fundadores, já se reveste de uma visada moderna e atual nos escritos em prosa e verso do pré-claridoso Eugénio, demonstrando o espírito visionário do intelectual nativista.

Para concluir, também os aspectos filosóficos e religiosos da sociedade crioula não escaparam à minúcia do escritor que, na poética de língua portuguesa, privilegia ora os contornos filosóficos do Amor, da Justiça e da Verdade, ora a religiosidade católicocristã: e, na poética crioula das mornas, enfatiza a filosofia popular.

O princípio brincalhão e satírico, originário do espírito coletivo e das mornas da ilha da Boavista, ladeia o sentimentalismo amoroso do espírito da Brava, proporcionando ao leitor momentos da mais aguda crítica e de refinado humor: a prosa jornalística e epistolar, os poemas em língua portuguesa e as mornas trabalham temas do cotidiano cabo-verdiano usando a palavra como arma para acutilar a incúria 
administrativa. A produção em língua portuguesa, nesse particular, torna mais veementes as denúncias, porque, segundo Brito-Semedo, "o homem cabo-verdiano, quando quer falar dos sentimentos, usa a língua materna; quando quer assumir outras posições, usa a língua portuguesa" (2009), como no caso dos posicionamentos políticos e sociais, em discursos diretamente endereçados aos mandatários coloniais.

Estendendo a toda a obra eugeniana (ao incorporar a lição de Brito-Semedo, na entrevista de 2009, de que "não é possível separar o Eugénio Tavares poeta do Eugénio Tavares jornalista") o que detecta Tomé Varela da Silva, a partir da produção jornalística, podemos:

realçar traços importantes da sua personalidade e carácter, patentear detalhes da sua visão, ressaltar a consciência que ele tinha da sua inserção no meio, apontar a crueza do seu realismo e focar, de alguma forma, o vigor do seu pensamento e a luminosidade da sua mensagem. [...] Aspectos educacionais, pedagógicos, antropológicos, administrativos, económicos, políticos, jurídicos lingüísticos, religiosos, humanitários e humorísticos, encontram-se aí retratados e poderão certamente prestar-se a reflexões diversas e deleites mil, para além de espalhar uma vasta e sólida bagagem informativa e cultural do seu ilustríssimo autor (1998, p. 59).

Desta forma, procuramos, em nossa pesquisa, abarcar as multifacetadas nuances temáticas e formais da produção em prosa e poesia de Eugénio Tavares, tendo a absoluta certeza de que não conseguimos, nem de perto, alcançar a magnitude de sua significação para a Pátria que tão bem soube enaltecer. Resta-nos o consolo de que o esforço foi grande e a missão continuará em etapas vindouras.

Fica-nos na memória, que se alinha à memória coletiva do povo ao qual Nhô Eugénio devotou a sua vida e a sua obra, a sua imagem:

Outrossim, a temática tão ligada ao imaginário colectivo de um Eugénio Tavares belo, perseguido, fugindo da Brava vestido de mulher, emigrando para a América, constantemente apaixonado, mornista exímio, fazem com que a sua imagem mantenha uma 'aura' quase mítica, até aos dias de hoje (LOBO, 1996, p. 8).

Todos os epítetos ${ }^{55}$ que lhe são atribuídos, em suma, devem-se ao merecimento que Cabo Verde reconhece e que Manuel Brito-Semedo assim resume, alçando-o ao estatus de ícone crioulo:

\footnotetext{
${ }^{55}$ O Camões de Cabo Verde; tradutor do sentimento da Raça; precursor do nativismo cabo-verdiano; grande vulto da cabo-verdianidade; o primeiro filólogo do crioulo; o primeiro poeta genuinamente cabo-
} 
durante um período de mais de 30 anos, mais ou menos de 1890 até 1930, quando de sua morte, Eugénio marcou profundamente a cultura cabovediana, em termos de sua produção, porque ele produziu até o fim da vida. Em termos de jornalismo, em termos do social, da política. Eugénio é marcante. Para mim, é o máximo! Depois dele só viriam outros que, para mim, são marcos de outras gerações como Baltasar Lopes e Amílcar Cabral. Mas como Eugénio, só Eugénio! (2009)

Nossa pesquisa tentou fazer jus a esse símbolo crioulo, embora com a intenção de trazer o mito para o campo da realidade de sua escrita literária, ainda pouco estudada e pouco divulgada. 


\section{REFERÊNCIAS BIBLIOGRÁFICAS}

\section{CORPUS:}

TAVARES, Eugénio. Mornas - cantigas crioulas. Luanda: Liga dos Amigos de Cabo Verde, 1969.

Eugénio. Eugénio Tavares: pelos jornais... MONTEIRO, Félix (Recolha, organização e prefácio). Praia, Instituto Caboverdiano do Livro e do Disco, 1997.

Eugénio Tavares - viagens,tormentas, cartas e postais. Recolha, organização e notas biográficas de Félix Monteiro. Prefácio de Manuela Ernestina Monteiro. Praia: Instituto Caboverdiano do Livro e do Disco, 1999.

Eugénio Tavares - poesias, contos, teatro. Recolha de Félix Monteiro. Organização e introdução de Isabel Lobo. Praia: Instituto Caboverdiano do Livro e do Disco, 1996.

\section{APOIO TEÓRICO-CRÍTICO:}

AGUIAR E SILVA, Vitor Manuel. Teoria da literatura. 3. ed. Coimbra: Almedina, 1979.

ALBUQUERQUE, Luís, e SANTOS, Maria Emília Madeira (coord.) História geral de Cabo Verde, vols. I, II, Lisboa: Centro de Estudos de História e Cartografia Antiga, Praia: Instituto Nacional de Investigação Cultural, 1995 e 2005.

ANDERSON, Benedict. Nação e consciência nacional. São Paulo: Ática, 1989.

ANDRADE, Hypolito Olympio da Costa. Instituição da imprensa política n'esta província. B. O., n. ${ }^{\circ}$ 46, Praia, 18 de novembro de 1871.

ARTILETRA - Jornal-Revista de Educação, Ciência e Cultura. Edição Ampliada. Ano IX, n. ${ }^{\text {s }} 34 / 35$ - junho/julho 2000. Número especial sobre Eugénio Tavares.

BANDEIRA, Manuel. Estrela da tarde. Rio de Janeiro: José Olympio, 1963.

BARBOSA, Jorge. Obra poética. Lisboa: Imprensa Nacional-Casa da Moeda, 2002.

BATALHA, Luís \& CARLING, Jorgen (Orgs.). Transnational archipelago: perspectives on Cape Verdean migration and diáspora. Amsterdam: Amsterdam University Press, 2008.

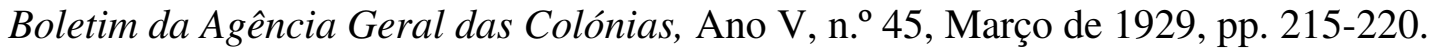


BRAGA, Teófilo. Introdução e teoria da história da literatura portuguesa. Porto: Lello \& Irmão, 1896.

. História da literatura portuguesa VI: o ultra-romantismo. Mem Martins: Publicações Europa-América, 1986.

BRITO-SEMEDO, Manuel. A construção da identidade nacional - análise da imprensa entre 1877 e 1975. Praia: Instituto da Biblioteca Nacional e do Livro, 2006.

- Eugénio Tavares. Entrevista concedida a Genivaldo Rodrigues Sobrinho e Grupo de Estudos Cabo-verdianos de Literatura e Cultura CNPq/USP, líder Simone Caputo Gomes, Praia, Cabo Verde, dezembro de 2009.

CAMÕES, Luís de. Poesia lírica. Seleção e introdução por Isabel Pascoal. Queluz: Biblioteca Ulisseia de Autores Portugueses, 1984.

CAMÕES, Luís Vaz de. Rimas. Intr. PIMPÃO, Álvaro. J. Costa. Coimbra: Livraria Almedina, 1994.

CAMPOS, Haroldo de. Bandeira, o Desconstelizador. In: Metalinguagem. Petrópolis: Vozes, 1967, p. 99-105.

CANCLINI, Néstor GARCIA. Culturas híbridas; estratégias para entrar e sair da modernidade. 4. ed. São Paulo: EDUSP, 2006.

CANIATO, Benilde Justo. Percursos pela África e por Macau. Cotia: Ateliê Editorial, 2005.

CARDOSO, Pedro. Folclore caboverdiano. Paris: Solidariedade Caboverdiana, 1983.

CARREIRA, António. Cabo Verde (aspectos sociais, secas e fomes do século XX). 2 ed. Lisboa: Ulmeiro, 1984.

CARVALHAL, Tânia Franco e COUTINHO, Eduardo de Faria. Literatura comparada: textos fundadores. Rio de Janeiro: Rocco, 1994.

O próprio e o alheio: ensaios de literatura comparada.

São Leopoldo, RS, Brasil: Editora Unisinos, 2003.

CASCUDO, Câmara. Dicionário do Folklore brasileiro. 3.ed. Rio de Janeiro: Editorial Tecnoprint, 1972.

CHALENDAR, Gérarde e Piettette. A paisagem na literatura cabo-verdiana. Revista África, Literatura, Arte e Cultura. Vol. II, n. ${ }^{\circ}$ 9, ano II. Lisboa, jul-set., 1980. 
CLARIDADE: revista de arte e letras (Ed. fac-similar.) $2^{\mathrm{a}}$ ed., Org. M. Ferreira. Lisboa: África Ed./Instituto do Livro e da Leitura, 1986.

COELHO, Jacinto do Prado. Dicionário de literatura. 3. ed. Porto: Figueirinhas, 1979, v. 4.

COUTINHO, Eduardo. A reconfiguração de identidades na produção literária da América Latina. Cadernos do Centro de Pesquisas Literárias da PUCRS. Anais do II Seminário Internacional da História da Literatura. Org. MOREIRA, Maria Eunice. Porto Alegre, 1998.

DIAS, Juliana Braz. Images of emigration in Cape Verdean music. In: Transnational archipelago: perspectives on Cape Verdean migration and diaspora. Edited by Luís Batalha. Amsterdam: Amsterdam University Press, 2008, pp. 173-189.

DUARTE, Dulce Almada. Bilinguismo ou diglossia. Praia: Spleen, 1998.

FANON, Frantz. Os condenados da terra. Trad. José Lourenço de Melo. Rio de Janeiro: Civilização Brasileira, 1968.

FERREIRA, Alberto. Perspectiva do romantismo português (1833-1865). 2. ed. Lisboa: Moraes Editores, 1971.

FERREIRA, Manuel. A aventura crioula. 3 ed. Lisboa: Plátano Editora, 1985.

.O círculo do mar e o "terra-longismo" em "Chiquinho" de Baltasar Lopes. In: Colóquio Letras. Lisboa, janeiro de 1972, pp. 66-70.

- O texto brasileiro na literatura caboverdiana. In: Literaturas africanas de língua portuguesa. Coord. Manuel Ferreira. Lisboa: Fundação Calouste Gulbenkian, 1987.

FORTES, Corsino. A cabeça calva de Deus: Pão \& fonema, Árvore \& tambor, Pedras de sol \& substância. Lisboa; Publicações Dom Quixote, 2001.

FRANÇA, Arnaldo. Panorama da literatura caboverdiana. Vértice, n. ${ }^{\circ}$ 55. Lisboa, julho/agosto, 1993.

FRANÇA, José-Augusto. O Romantismo em Portugal. Lisboa: Livros Horizonte, 1974. v. 4.

GARMES, Helder. A convenção formadora: uma contribuição para o periodismo literário nas colônias portuguesas. Tese de Doutorado. S. Paulo: USP, 1999. Orientador: Benjamin Abdala Jr. 
GOMES, Simone Caputo. Uma recuperação de raiz: Cabo Verde na obra de Daniel Filipe. Praia: Instituto Caboverdiano do Livro e do Disco, 1993.

Echoes of Cape Verdean Identity: Literature and Music in the Archipelago. In: Cape Verde: language, literature \& music. Organização de LEITE, Ana Mafalda. Dartmouth: Portuguese Literary \& Cultural Studies, University of Massachusetts Dartmouth, n. 8, 2003, pp. 265-285.

Cabo Verde: literatura em chão de cultutra. São PauloPraia: Ateliê Editorial-Instituto da Biblioteca Nacional e do Livro de Cabo Verde, 2008.

GONÇALVES, Carlos Filipe. Kab Verd band. Praia: Instituto do Arquivo Histórico Nacional, 2006.

HALBWACHS, Maurice. Fragmentos da la Memoria Colectiva. Revista de Cultura Psicológica, Año 1, N. ${ }^{\circ}$ 1, México, UNAM- Facultad de Psicologia, 1991.

. A memória coletiva. São Paulo: Vertice, 1990.

HALL, Stuart. A identidade cultural na pós-modernidade. 3.ed. Rio de Janeiro: DP\&A Editora, 1997.

HAMILTON, Russell. Literatura africana, literatura necessária, II - Moçambique, Cabo Verde, Guiné-Bissau, São Tomé e Príncipe. Lisboa: Edições 70, 1984.

HERNANDEZ, Leila Leite. Os filhos da terra do sol: a formação do estado-nação em Cabo Verde. São Paulo: Selo Negro, 2002.

LABAN, Michel. Cabo Verde: encontro com escritores. Porto: Fundação Eng. António de Almeida, 1992. 2v.

LARANJEIRA, Pires. Literaturas africanas de expressão portuguesa. Lisboa: Universidade Aberta, 1995.

De letra em riste: identidade, autonomia e outras questões nas literaturas de Angola, Cabo Verde, Moçambique e S. Tomé e Príncipe. Porto: Afrontamento, 1992.

LIMA, António Germano. A morna: síntese da espiritualidade do povo cabo-verdiano. In: Africana. Porto, 6: Universidade Portucalense, 2001, pp. 237-267.

LOPES, José. Eugénio Tavares. In: Eugénio Tavares - viagens, tormentas, cartas e postais. Recolha, organização e notas biográficas de Félix Monteiro. Prefácio de Manuela Ernestina Monteiro. Praia: Instituto Caboverdiano do Livro e do Disco, 1999, pp. 294-296. 
LOPES FILHO, João. Imigrantes em terra de emigrantes. Praia: Instituto da Biblioteca Nacional e do Livro, 2007.

LOTMAN, Iuri. A composição da obra artística verbal. In: A estrutura do texto artístico. Trad. Maria do Carmo Vieira Raposo e Alberto Raposo. Lisboa: Editorial Estampa, 1978.

LOUDE, Jean-Yves. Cabo Verde: notas atlânticas. Trad. Maria Fernanda Oliveira. Mira-Sintra: Europa-América, 1999.

MARIANO, Gabriel. Amor e partida na poesia crioula de Eugénio Tavares ou inquietação amorosa. In: Cultura caboverdeana - ensaios. Lisboa: Vega, 1991.

MARTINS, Vasco. A música tradicional cabo-verdiana - I (A morna). Praia: Instituto Cabo-Verdiano do Livro e do Disco, 1989.

Ventos alíseos. Rèvue Noire. Praia: Bleu outremer, 10. Sept - nov. 1993.

MEMMI, Albert. Retrato do colonizado precedido pelo retrato do colonizador. Trad. Roland Corbisier e Mariza Pinto Coelho. Rio de Janeiro: Paz e Terra, 1967.

MOISÉS, Massaud. Literatura brasileira através dos textos. 10. ed. São Paulo: Cultrix, 1983, p. 18 b.

NITRINI, Sandra. Literatura comparada: história, teoria e crítica. São Paulo: EDUSP, 1998.

NOGUEIRA, Gláucia. O tempo de B. Léza: documentos e memórias. Praia: Instituto da Biblioteca Nacional e do Livro, 2005.

OLIVEIRA, João Nobre de. A imprensa cabo-verdiana 1820-1975. Macau: Fundação Macau, 1998.

OSÓRIO, Oswaldo. Cantigas de trabalho (Tradições orais de Cabo Verde). Praia: Edição da Comissão Nacional para as Comemorações do $\mathrm{V}$ Aniversário da Independência Nacional, 1980.

PEIXEIRA, Luís Manuel de Sousa. Da mestiçagem à caboverdianidade: registos de uma sociocultura. Lisboa: Edições Colibri, 2003.

QUENTAL, Antero de. Sonetos completos. Edição organizada, prefaciada e anotada por António Sérgio. 4. ed. Lisboa: Sá da Costa, 1972.

REIS, José Alves dos \& LOPES, Baltasar. Subsídios para o estudo da morna. Raízes. Praia, 21, junho de 1984, pp. 9-18. 
RODRIGUES, Moacyr \& LOBO, Isabel. A morna na literatura tradicional: fonte para estudo histórico-literário e a sua repercussão na sociedade. Praia: Instituto Caboverdiano do Livro e do Disco, 1996.

17 de janeiro de 1986.

B. Léza $80^{\circ}$ aniversário. Suplemento do VP,

ROMANO, Luís. "Nos Fidjutxôn”. In: Kabverd: civilização \& cultura. Rio de Janeiro: Minerva Press do Brasil, 2000.

Perfil de Eugénio Tavares. In: Ponto \& vírgula: revistad $e$ intercâmbio cultural, n. 16, janeiro-julho, Mindelo, 1986, p. 2-8.

SAID, Edward. Representações do intelectual: as conferências de Reith de 1993. Trad. Milton Hatoum. São Paulo: Companhia das Letras, 2005.

Reflexões sobre o exílio e outros ensaios. Trad. Pedro Maia Soares. São

Paulo: Companhia das Letras, 2003.

SANTOS, Antônio Carlos Oliveira. Eugénio Tavares: poesia e convenção romântica. Dissertação de Mestrado. S. Paulo: USP, 2007. Orientador: Helder Garmes.

SARAIVA, António José \& LOPES, Óscar. História da literatura portuguesa. Porto: Porto Ed, 1970

SEIXO, Maria Alzira. Discursos do texto. Amadora: Livraria Bertrand, 1977.

SILVA Luís. "Os exílios na literatura caboverdiana". In: Latitudes: cahiers lusophones. Paris, n. ${ }^{\circ}$ 27, setembro de 2006, pp. 23-30.

SILVA, Tomé Varela da. Eugénio Tavares pelos jornais... In: Revista Pré-textos, dez. 98. Praia: Associação dos Escritores de Cabo Verde, 1998, pp. 56-59.

SOUSA, Teixeira de. "Curcutiçan" (Recolhas Folclóricas). Cabo Verde - Boletim de Propaganda e Informação, n. ${ }^{\circ}$ 63, Praia, dez. de 1954, p. 18.

\section{WEBGRAFIA:}

BARROS, Carlota \& BARROS, Viriato. O amor em Eugénio Tavares. Disponível em: http://www.eugeniotavares.org/docs/pt/noticias/amor_em_eugenio_tavares.html. Acesso em maio de 2010.

CARDINI, Franco. A memória coletiva no pensamento de M. Halbwachs. Conferência proferida no Instituto de Psicologia da Universidade de São Paulo em 10 de novembro de 
1993. Disponível em: http://scielo.bvs-psi.org.br/scielo.php?pid=S1678$51771993000100013 \&$ script=sci_arttext\&tlng=pt. Acesso em maio de 2010.

FORTES, Corsino. Eugénio Tavares: um construtor do humanismo cabo-verdiano. Disponível em: Humanismo Latino Online. http://www.humanismolatino.online.pt. Acesso em maio de 2010.

FUNDAÇÃO EUGÉNIO TAVARES. Disponível em www.eugeniotavares.com. Acesso em maio de 2010.

GOMES, Simone Caputo. Amar Cabo Verde. Disponível em www.simonecaputogomes.com. Acesso em maio de 2010.

GUIMARÃES, José António Nobre Marques. O nativismo em Eugénio Tavares. Disponível no site da Fundação Eugénio Tavares. Disponível em: www.eugeniotavares.com. Acesso em maio de 2010.

LIMA, Antonio Germano. EUGÉNIO TAVARES: contribuição para a investigação históricocultural da sociedade cabo-verdiana. Disponível em http://transcv.blogspot.com/2006/12/eugniotavares-contribuio-para.html. Acesso em maio de 2010.

MONTEIRO, Fátima. Cabo Verde na encruzilhada atlântica. Disponível em: http://www.ieei.pt/files/Cabo_Verde_encruzilhada_atlantica_Fatima_Monteiro.pdf. Acesso em maio de 2010.

PINA, Maria da Graça Gomes de. $O$ crioulo na poesia caboverdiana da primeira metade do século XX. Disponível em: http://www.fflch.usp.br/dlcv/revistas/crioulal. Acesso em maio de 2010.

SPÍNOLA, Danny. A cultura cabo-verdiana e suas raízes etno-culturais. Disponível em http://caboverde.vozdipovoonline.com/index2.php?option=com_content\&do_pdf=1\&id=19. Acesso em maio de 2010. 